\title{
Cinco siglos de historia de Riosucio (Caldas) Con énfasis en la conformación del territorio.
}

Luis Javier Caicedo
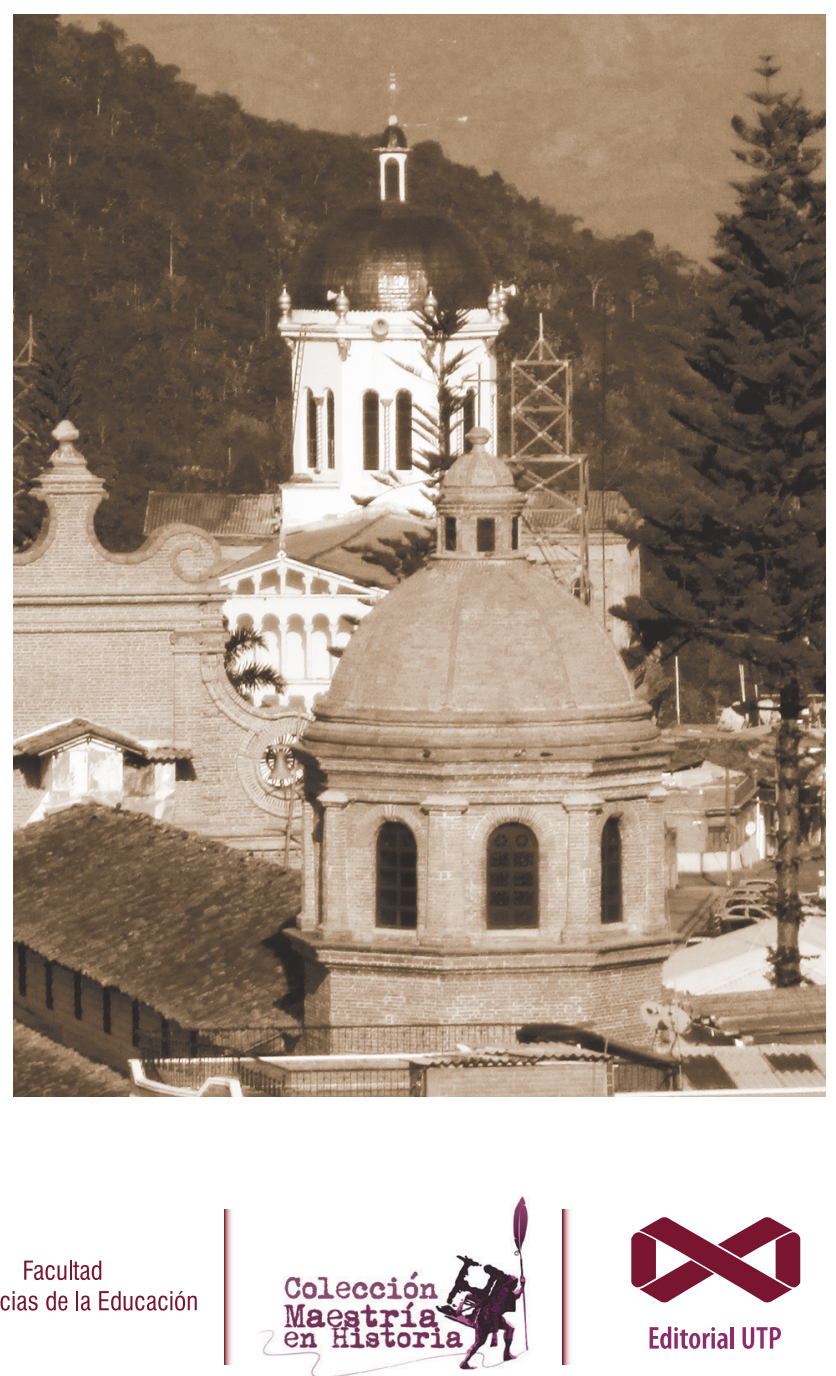

Editorial UTP 


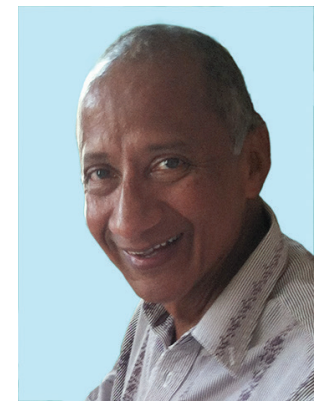

Luis Javier Caicedo,

(Medellín, Antioquia, Colombia, 1957).

Autor de los libros: Derechos y deberes de los pueblos indígenas (1995), 1810-2010: Bicentenario de la Independencia de Colombia y de Latinoamérica (2005), Los títulos de San Lorenzo. Estudio de los títulos de propiedad del Resguardo Indígena de San Lorenzo (2011). Compilador de Santander, la República (1995).

$1^{\text {a }}$ Mención en la II Convocatoria "Construir Bicentenarios Latinoamericanos en la Era de la Globalización”. 2011. UBA (Buenos Aires), Observatory of LatinAmerica (Nueva York) y UNAM (México).

Ha publicado artículos en revistas especializadas nacionales e internacionales.

albicentenario2019@gmail.com 


\section{CINCO SIGLOS DE HISTORIA DE RIOSUCIO (CALDAS)}

Con énfasis en la conformación del territorio

Luis Javier Caicedo

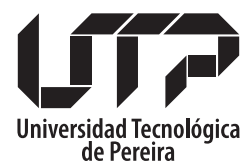

Facultad de Ciencias de la Educación

Colección Ensayos

Colección Maestría en Historia

2018 
Caicedo, Luis Javier

Cinco siglos de historia de Riosucio (Caldas) con énfasis en la conformación del territorio / Luis Javier Caicedo. - Pereira :

Universidad Tecnológica de Pereira, 2018.

164 páginas : ilustrado. - (Colección Ensayos).

ISBN: 978-958-722-307-1 eISBN: 978-958-722-542-6

1. Riosucio - Caldas (Colombia) - Resguardos indígenas 2. Riosucio - Caldas (Colombia) -

Colonización de tierras 3. Riosucio - Caldas (Colombia) - 1846-1948 4. Mestizaje - Historia

- Riosucio - Caldas (Colombia) 5. Colonización española - Riosucio - Caldas (Colombia) 6.

Regionalismo - Historia - Caldas (Colombia)

CDD 986.105

CLuis Javier Caicedo

(c)Universidad Tecnológica de Pereira

(c) Municipio de Riosucio

Primera edición

eISBN: 978-958-722-542-6

ISBN: 978-958-722-307-1

Universidad Tecnológica de Pereira

Vicerrectoría de Investigaciones, Innovación y Extensión

Editorial Universidad Tecnológica de Pereira

Pereira, Colombia

Coordinador editorial:

Luis Miguel Vargas Valencia

luismvargas@utp.edu.co

Teléfono 3137381

Edificio 9, Biblioteca Central "Jorge Roa Martínez"

Cra. 27 No. 10-02 Los Álamos, Pereira, Colombia

www.utp.edu.co

Montaje y producción:

Recursos Informáticos y Educativos CRIE

Universidad Tecnológica de Pereira

Impresión y acabados:

Publiprint S.A.S

Pereira

Reservados todos los derechos 




\section{TABLA DE CONTENIDO}

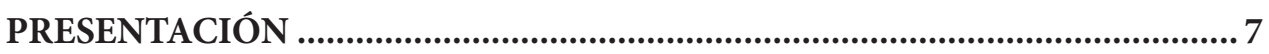

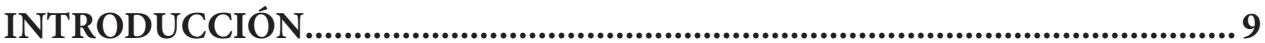

SIGLO XVI

Marco geográfico. Pueblos originarios. La llegada de los españoles. La organización colonial. Los reales de minas, los pueblos de indios y los resguardos

\section{SIGLO XVII}

Visita de Lesmes de Espinosa y Saravia a las provincias de Anserma, Cartago, Arma y Toro (1627). Fundación de los pueblos de indios y los resguardos en la Provincia de Anserma, en especial de La Montaña y la Vega de Supía. Tierras entregadas a los españoles. Las Ordenanzas de Anserma

\section{SIGLO XVIII}

Intento fallido de trasladar a los indios de Lomaprieta para Supía la Baja en 1701. El pueblo de Cañamomo le gana el sitio de Riosucio al pueblo de La Montaña en 1721. En 1751 el pueblo de La Montaña recupera el sitio de Riosucio. En 1758 se declara la unión de los pueblos de Cañamomo y Supía la Baja. Los indígenas de La Montaña compran los terrenos de Pirza en 1759. Los quiebralomeños se introducen al sitio de Riosucio. Cómo era el territorio de Riosucio en 1771.

\section{SIGLO XIX}

El último proyecto territorial de la Corona española en la Vega de Supía. Proceso de fundación de Riosucio (1814-1819). Riosucio visto por J. B. Boussingault en 1825-1830. El mestizaje. Los nombres que ha tenido Riosucio. Reposición del título de San Lorenzo en 1836. Erección de Riosucio en Distrito Municipal (1846), unificación de las dos parroquias y surgimiento del Carnaval. Continuidad de los resguardos indígenas en la República. El recorte del gran Resguardo de Supía y Cañamomo (1874). Registro de la Comunidad de Escopetera Pirza (1884). El área de población de Riosucio (1873 - 1890). La colonización antioqueña, la Oraida y el pueblo de El Rosario. La ley 89 de 1890 y las aprensiones de San Lorenzo. 


\section{SIGLO XX}

La creación del Departamento de Caldas (1905). Escopetera Pirza se separa del Resguardo de La Montaña y elige Cabildo propio (1913). Monografía de Riosucio en el Centenario. El proyecto nacional para disolver los resguardos indígenas coloniales, empezando por los de Riosucio, y en particular por San Lorenzo (1939-1943). La posición de los Cabildos de Riosucio frente a la disolución (San Lorenzo, Nuestra Señora Candelaria de la Montaña, Cañamomo Lomaprieta, el caso de Escopetera Pirza). Visita antropológica de Luis Duque Gómez a Riosucio en 1943. La reforma urbana de los años treinta a cincuenta y sus efectos sobre la existencia de los resguardos. Del cambio de política indigenista del Estado en 1958 a la Constitución de 1991

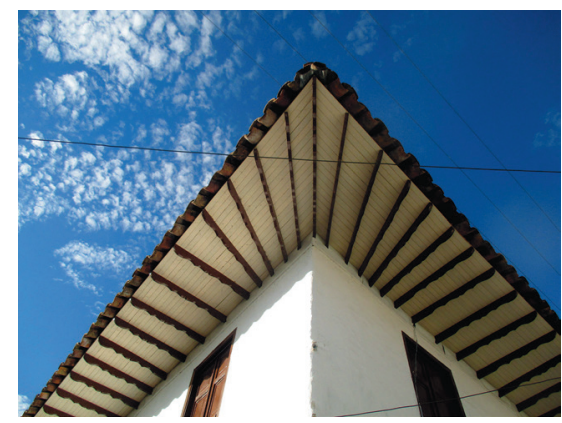

Casa de la carrera $5^{a}$ con calle $5^{a}$, esquina 


\section{PRESENTACIÓN}

El pasado 7 de agosto de 2018 Riosucio cumplió 199 años de fundación. Ese día dimos apertura a la conmemoración de 200 años de historias, magia, cultura y tradiciones que nos caracterizan como un municipio sui-generis en la geografía colombiana, además de la coincidencia con el Bicentenario de la batalla de Boyacá. En este inicio queremos invitar a riosuceños y visitantes a hacer tejido social, a empoderarse del Municipio y a construir a favor de éste, porque debemos hacer evidente el amor que le profesamos, porque su pasado y su presente nos han constituido en lo que somos y le han dado fuerza a lo que nos identifica.

No podía faltar en la conmemoración el relato histórico, pero no solo del momento coyuntural de la fundación, sino de manera panorámica, que dé cuenta de los antecedentes de tres siglos que transcurrieron desde la llegada de los españoles en 1536, hasta el acto fundacional de 1819, pero que incluya también los sucesos ocurrido en los dos siglos siguientes, hasta acercarnos al presente.

Esta perspectiva permite apreciar, como lo recalca en sus conferencias el profesor Albeiro Valencia Llano, que la de Riosucio no es una historia local sino regional y aún nacional. También lo confirman el historiador Germán Arciniegas, para quien "Riosucio es la imagen de la República", y la historiadora estadounidense Nancy Appelbaum, quien escribió un libro titulado "Riosucio: Dos Plazas y una Nación".

Constituye un honor para los riosuceños que la Universidad Tecnológica de Pereira (UTP), a través de la Maestría en Historia, haya tomado la iniciativa de vincularse a la conmemoración del Bicentenario de la Fundación de nuestro Municipio, con la publicación de esta útil obra. El pueblo y el Gobierno de Riosucio les quedamos muy agradecidos.

Nuestra gratitud también para el ex alcalde Abel David Jaramillo Largo, en cuya mandato se desarrolló la investigación para este libro, así como para su autor, Luis Javier Caicedo, reconocido asesor de las comunidades indígenas del Departamento de Caldas.

BERNARDO ARLEY HERNÁNDEZ AYALA

Alcalde 



\section{INTRODUCCIÓN}

La presente reseña pretende proporcionar una visión panorámica del proceso de conformación del territorio del Municipio de Riosucio, en el Departamento de Caldas, el cual tiene de singular -al interior del Eje Cafetero colombiano- que tanto su ruralidad como su componente urbano están atravesados por la continuidad de los Resguardos Indígenas creados desde el siglo XVII en la antigua Gobernación de Popayán.

El texto resume la investigación adelantada por el autor desde el año 2006 en su trabajo de asesoría para el Consejo Regional Indígena de Caldas (CRIDEC), el Cabildo Indígena de San Lorenzo y para la Alcaldía de Riosucio, sucesivamente, con la finalidad de servir de insumo al Proyecto Embera Kirimcha Harapadadé (Escuela de Pensamiento Propio), al saneamiento integral del Resguardo de San Lorenzo, al Plan de Salvaguarda del Pueblo Embera de Caldas y al proceso de revisión y ajuste del Plan Básico de Ordenamiento Territorial Municipal (PBOT).

La obra está dirigida a su lectura por las autoridades y los distintos sectores sociales de Riosucio, por su relación con el PBOT de este municipio; pero está redactada en clave regional, porque la historia de Riosucio es "Más que una historia local", como tituló el profesor Albeiro Valencia Llano una conferencia que dictó en la Universidad de Caldas en 2013.

Entre los criterios seguidos para la elaboración de este trabajo figuran los siguientes:

- Énfasis en la conformación del territorio. En este sentido no se trata de una "Historia General de Riosucio", la cual excedería la finalidad del ejercicio, sino de una aproximación a la historia del territorio del actual Municipio. Este enfoque deja por fuera importantes aspectos de la construcción cultural, social, urbana y económica de Riosucio, y a sus protagonistas, pero sobre ellos existe una amplia bibliografía entre los autores riosuceños.

- Presentación por siglos, puesto que una de las dificultades detectadas para comprender el territorio riosuceño consiste en concebir la historia de todo el municipio concentrándose sólo en la fundación del núcleo urbano en 1819, como si no existiera el área rural y como si tampoco hubiera un antes y un después de los padres José Bonifacio Bonafont y José Ramón Bueno. Y aunque la segmentación de la historia por siglos tiene sus limitaciones, lo cierto es que en Riosucio es posible decir que cada siglo ha dejado marcada su impronta sobre el territorio.

- La historia somos todos. La exposición tiene un carácter pedagógico, dirigido, en primer lugar, a "aprender a querer a Riosucio desde el principio", como dijera una entrañable maestra con motivo de la celebración de los 475 años 
del nombre de Riosucio en 2013; pero también dirigido a poner al acceso del público los documentos antiguos, a veces en su transcripción literal, para que un mayor número de personas se familiarice con las fuentes de investigación y con los archivos donde éstas pueden encontrarse, y de esta manera cada uno pueda hacer su lectura personal y adelantar sus propias indagaciones. En el Bicentenario de la Independencia en 2010 la Universidad de Antioquia acuñó un lema: "La Historia Somos Todos", y ello requiere que el legado de las generaciones anteriores esté disponible para la consulta actual y así proseguir las lecciones exitosas o corregir los errores del pasado.

- Principio de prudencia o cautela. A pesar de los trabajos de investigación adelantados por historiadores locales, regionales y aún del exterior, y de la recopilación emprendida por los ResguardosindígenasyporlaAdministración Municipal, quedan muchas lagunas sobre el pasado de Riosucio. Aún se está lejos de una versión, no digamos "verdadera", porque en temas de historia nadie se puede atribuir la última palabra, sino de una versión integral, comprensiva del pasado del municipio, pues, por ejemplo, entre documento y documento a veces pasa medio siglo, cuando no es que a un documento le podemos estar dando una importancia mínima o desmesurada respecto de su contexto y de su significado. De ahí que la presente reseña, aunque útil como insumo para el proceso de revisión del PBOT, es básicamente una aproximación, una síntesis razonable de la historia del territorio riosuceño, sin perjuicio de que otros enfoques o nuevos documentos arrojen mejores luces sobre los acontecimientos del pasado, y siempre con la esperanza puesta en que la apropiación social del conocimiento posibilite acercarse un día a la construcción de una historia general del municipio. 


\section{SIGLO XVI}





\section{Marco geográfico. Pueblos originarios. La llegada de los españoles. La organización colonial. Los reales de minas, los pueblos de indios y los resguardos}

\section{Marco geográfico}

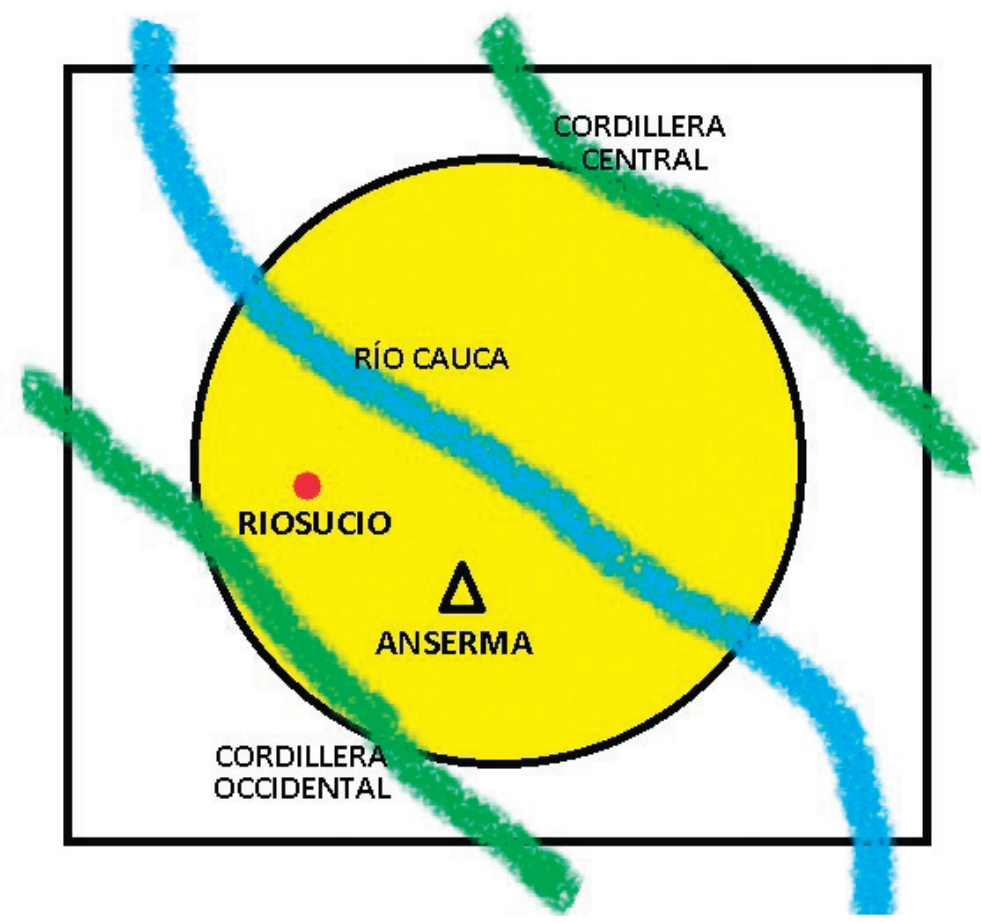

Ubicación de Riosucio en la región del Cauca Medio

Como hoy, el territorio pertinente para el siglo XVI es la macrocuenca del río Cauca en su curso medio, entre el río de La Vieja al Sur y los ríos Arma y Arquía al Norte. A lo ancho, la cima nevada de la Cordillera Central al Oriente y al Occidente la cima de la Cordillera Occidental. No es todo el Cauca Medio, el cual baja hasta Ituango (Antioquia), sino la parte que recorre el Viejo Caldas.

El territorio así delimitado constituía el hábitat de varias naciones indígenas con rasgos culturales comunes a lado y lado del río Cauca, caracterizadas por ser sociedades agrícolas y mineras, sedentarias, organizadas en Señoríos que centralizaban múltiples cacicazgos, con poblaciones o aldeas de viviendas juntas y plazas, con idiomas que 
abarcaban grandes extensiones, con relaciones de comercio y de guerra entre los pueblos de ambas riberas, etc.

Estas naciones se distinguían, tanto en su hábitat ecológico como en su forma de vida, de las naciones circunvecinas, ubicadas en los actuales Valle del Cauca, Antioquia, Chocó y Oriente Caldense.

A diferencia del actual territorio antioqueño, donde predominaban las montañas quebradas y cubiertas de selva y los indígenas vivían dispersos o en muy pequeñas aldeas, en el actual Centro-Occidente Caldense las montañas eran más bien cerros "sin monte" y en ellos construían sus pueblos los nativos. Los "arcabucos de cañas gordas" (guaduales) constituían el paisaje predominante. Los habitantes no se establecían a la orilla del río Cauca, por malsano, sino en la vertiente de las dos cordilleras.

Aproximándonos más a Riosucio, el municipio hace parte del territorio del Cauca Medio comprendido en la margen izquierda del río Cauca, desde donde terminan las sabanas del Valle del Cauca (hoy Ansermanuevo) hasta Marmato, límite con Antioquia.

En cuanto al territorio comarcano del actual Municipio de Riosucio, él corresponde a las microcuencas de los ríos Supía (“Zupía”) y Risaralda ("Sopinga”), que hacen parte de la macrocuenca del río Cauca, y durante los tres siglos de la época de la Colonia fue conocido por los españoles como La Montaña, en la parte alta, y la Vega de Supía, en la parte baja.

\section{Pueblos originarios}

En la subregión de la margen izquierda del río Cauca no existió una nación unificada como los Quimbaya, los Carrapa o los Arma de la orilla opuesta del río, sino pequeños pueblos que compartían el territorio y la lengua pero sin un gobierno unificado, aunque con dos Señores principales: Ocuzca y Humbruza. Esta dispersión hizo que, a su llegada, los españoles designaran la subregión con el nombre genérico de "Anserma".

"Anserma" no es, por tanto, una palabra nativa sino un vocablo acuñado por los españoles en 1536, como lo explica el propio Jorge Robledo:

... la cual se dice Ancerma; porque cuando la primera vez entramos en ella con el capitán Benalcázar, entramos sin lenguas o sea, indígenas traductores y con muy grande falta de sal, e cuando se tomaba algún indio, le preguntábamos por señas por sal, a la cual ellos en su lengua nombraban "ancer", y por este vocablo de ancer, como no aprendimos otro, la llamamos Ancerma, que su natural nombre de la provincia es Humbra ${ }^{3}$.

3 Jorge Robledo, Descripción de los pueblos de la provincia de Anserma, 1543, aprox. 
En la misma crónica Robledo describió los pueblos indígenas que podía identificar hacia 1543 en torno de la ciudad de Santa Ana de los Caballeros (Anserma Viejo):

Los pueblos que hay alrededor de la ciudad de Santa Ana de indios, son los siguientes, que están en la provincia de Humbra, la cual se dice Ancerma (...).

Está en el valle de Amiceca, el cual yo puse el valle de Santa María, ques un valle muy poblado; está este valle tres leguas de la ciudad, hacia la parte del Norte; están en este valle muchos pueblos e de muchos nombres; entre medias dél y de la ciudad está el pueblo del Peñol y ansí en comarca está el otro valle de muchos pueblos que se dice Chanvuruqua, questá una legua de la ciudad, en el cual hay muchos pozos de agua salada, de donde se hace sal: el cual dicho valle nasce de donde nasce el de Santa María, sino que corre hacia donde nasce el sol.

Están, a la parte donde nasce el sol, los pueblos de Irra, e Angasca, e Guacayca, e Aconchare e otros muchos, a cuatro o cinco leguas de la ciudad.

Está, a la parte del Poniente, Guarma, el valle de Apía, Chatapa, Andica, Humbría y la provincia de Taupa; fuera destas, hay otras provincias, que son anexas a esta ciudad, que son Carantama [Cartama] e Caramanta e otros pueblos que están así apartados; y pasada la cordillera que va por la cima de la ciudad de Santa Ana hacia la mar del Sur [Océano Pacífico], está la provincia de Chocó ${ }^{4}$.

El siguiente cuadro, elaborado en $1560^{5}$, veinte años después de la entrada de los españoles, y coincidente con la visita a la zona del oidor Tomás López Medel y de Juan del Valle, obispo de Popayán, permite conocer los nombres de las naciones originarias (salvo las que desaparecieron con la guerra), así como las primeras encomiendas:

4 Ídem. Jorge Robledo: “Descripción de los pueblos de la provincia de Anserma”, 1543.

5 “Relación de Popayán y del Nuevo Reino" de 1559-1560 (en Cespedesia, revista de la Universidad del Valle, Nos. 45-46, suplemento No. 4, enero-junio de 1983) (Ver Anexo 2). Juan Friede, en el libro Vida y luchas de don Juan del Valle, primer obispo de Popayán (Popayán, 1961) trae una lista de pueblos encomendados muy similar a la presente. 


\section{Cuadro de Encomiendas en La Provincia de Anserma 1560}

\begin{tabular}{|c|c|c|c|c|c|}
\hline $\begin{array}{l}\text { Fanegas } \\
\text { de sem- } \\
\text { bradura }\end{array}$ & Vecinos & Pueblos de indios & $\begin{array}{l}\text { No. de } \\
\text { indios }\end{array}$ & $\begin{array}{l}\text { Tasas de } \\
\text { mantas }\end{array}$ & $\begin{array}{l}\text { Indios de } \\
\text { minas }\end{array}$ \\
\hline 16 & $\begin{array}{l}\text { Gaspar de Loaiza, soltero, } \\
\text { conquistador y poblador }\end{array}$ & $\begin{array}{l}\text { Carpa } \\
\text { Supía }\end{array}$ & $\begin{array}{l}300 \\
100 \\
\end{array}$ & $\begin{array}{r}400 \\
- \\
\end{array}$ & 40 \\
\hline 16 & $\begin{array}{l}\text { Lázaro Martín, soltero, } \\
\text { conquistador y poblador }\end{array}$ & Upirama & 400 & 450 & 30 \\
\hline 3 & Juan Pérez, difunto & Ipa & 60 & 60 & 20 \\
\hline 6 & $\begin{array}{l}\text { Andrés Pérez, soltero, } \\
\text { conquistador y poblador }\end{array}$ & Ocanchara & 150 & 150 & 20 \\
\hline 16 & $\begin{array}{l}\text { Francisco Díaz, soltero, } \\
\text { conquistador y poblador }\end{array}$ & $\begin{array}{l}\text { Napura } \\
\text { Irra } \\
\text { Tabuya }\end{array}$ & $\begin{array}{r}250 \\
60 \\
200 \\
\end{array}$ & $\begin{array}{r}500 \\
- \\
-\end{array}$ & $\begin{array}{r}60 \\
-\end{array}$ \\
\hline 16 & $\begin{array}{l}\text { Gil Rengifo, conquistador y } \\
\text { poblador }\end{array}$ & $\begin{array}{l}\text { Guática } \\
\text { Tusa } \\
\text { Indipia }\end{array}$ & $\begin{array}{r}350 \\
80 \\
20\end{array}$ & $\begin{array}{r}250 \\
- \\
-\end{array}$ & $\begin{array}{r}30 \\
-\end{array}$ \\
\hline 12 & $\begin{array}{l}\text { Bartolomé de la Rosa, } \\
\text { casado, conquistador y } \\
\text { poblador }\end{array}$ & $\begin{array}{l}\text { Curumbi } \\
\text { Curupancha } \\
\text { La Provincia }\end{array}$ & $\begin{array}{r}200 \\
50 \\
50 \\
\end{array}$ & $\begin{array}{r}300 \\
- \\
-\end{array}$ & $\begin{array}{r}40 \\
-\end{array}$ \\
\hline 14 & $\begin{array}{l}\text { Antón de Sequera, casado, } \\
\text { conquistador y poblador }\end{array}$ & $\begin{array}{l}\text { Cumba } \\
\text { Andica } \\
\end{array}$ & $\begin{array}{l}300 \\
100 \\
\end{array}$ & $\begin{array}{r}400 \\
- \\
\end{array}$ & 40 \\
\hline 12 & $\begin{array}{l}\text { Miguel Dávila, casado, } \\
\text { conquistador y poblador }\end{array}$ & $\begin{array}{l}\text { Chátaga } \\
\text { Ocanchare }\end{array}$ & $\begin{array}{l}150 \\
160 \\
\end{array}$ & $\begin{array}{r}- \\
300 \\
\end{array}$ & 50 \\
\hline 4 & $\begin{array}{l}\text { Juan de Moreta, casado, } \\
\text { conquistador y poblador }\end{array}$ & Guacaica & 80 & 80 & 30 \\
\hline 20 & $\begin{array}{l}\text { Lorenzo de Serrano, soltero, } \\
\text { conquistador y poblador }\end{array}$ & Apía & 600 & 500 & 50 \\
\hline 16 & $\begin{array}{l}\text { Gómez Hernández, casado, } \\
\text { conquistador y poblador }\end{array}$ & $\begin{array}{l}\text { Pirsa } \\
\text { Supinga }\end{array}$ & $\begin{array}{r}400 \\
50 \\
\end{array}$ & $\begin{array}{r}500 \\
- \\
\end{array}$ & 50 \\
\hline 14 & $\begin{array}{l}\text { Lucas Dávila, soltero, } \\
\text { conquistador y poblador }\end{array}$ & Supía & 400 & 400 & 40 \\
\hline 8 & $\begin{array}{l}\text { Hernando Benítez, casado, } \\
\text { conquistador y poblador }\end{array}$ & Apía & 200 & 200 & 25 \\
\hline 8 & $\begin{array}{l}\text { Juan de Zúñiga, casado, } \\
\text { conquistador y poblador }\end{array}$ & $\begin{array}{l}\text { Gorrones } \\
\text { Atilla }\end{array}$ & $\begin{array}{l}100 \\
100 \\
\end{array}$ & $\begin{array}{r}- \\
200 \\
\end{array}$ & 25 \\
\hline 10 & $\begin{array}{l}\text { Antón de Pantoja, casado, } \\
\text { conquistador y poblador }\end{array}$ & $\begin{array}{l}\text { Gorrones } \\
\text { Umbría }\end{array}$ & $\begin{array}{r}200 \\
50 \\
\end{array}$ & $\begin{array}{r}250 \\
-\end{array}$ & 25 \\
\hline 6 & $\begin{array}{l}\text { Hernando de Pardo, soltero, } \\
\text { conquistador y poblador }\end{array}$ & Guarma & 150 & 150 & 20 \\
\hline 4 & $\begin{array}{l}\text { Alonso Gómez, casado, } \\
\text { poblador }\end{array}$ & Chatapa & 100 & 100 & 20 \\
\hline 201 & 16 & 30 & 5.410 & 5.190 & 615 \\
\hline
\end{tabular}


A los veinticinco pueblos enumerados en este cuadro habría que agregar otros dos, Sima y Chancos, que una nota del autor del informe dice que aún no habían sido sometidos:

Dos provincias de naturales están junto a las que sirven a esta ciudad [Anserma], de los cuales reciben daño, porque continuamente vienen a hacer asaltos en ella y matan algunos, y asimismo salen a los caminos a los caminantes que van por tierra a Cali. Llámanse estas provincias la una Sima y la otra Los Chancos; habrá en ellas mil y quinientos indios 6 .

Se calcula que a la llegada de los españoles (1536-1539) había 40.000 indígenas en la provincia de Anserma. Para 1560, 6.025 indígenas. Y para 1580 sólo entre 800 y $1.500^{7}$. Es decir, en 40 años pereció el 95\% de la población nativa.

Estos datos no se incluyen en esta reseña para eternizar la Leyenda Negra ni para refregar neciamente el imaginario político de los 500 años, sino para entender la historia que siguió, puesto que el exterminio generalizado o la crisis demográfica, como se le quiera llamar, determinó que para garantizar la sobrevivencia de la población nativa (y por ende de su mano de obra y de su capacidad de tributo), la Corona española tomara dos medidas cuyos fines y efectos perduran hasta el día de hoy en Riosucio y el territorio adyacente, como fueron: 1) la concentración de los restos de la población nativa en "pueblos de indios" con sus respectivos Resguardos, y 2) la introducción de población africana en condiciones de esclavitud".

6 Ídem. Los cronistas identifican a "Sima" como la montaña existente entre Riosucio y Mistrató. Los indios Chancos vivían entre Tuluá y Buga, en un sitio donde en el siglo XIX se libró la batalla de los Chancos, en la cual participó un grupo de indígenas riosuceños, quienes al regresar le pusieron el nombre de "Chancos" a su comunidad, en el Resguardo de La Montaña (dato suministrado por don Julián Bueno).

7 Un informe de 1582 de fray Jerónimo de Escobar para el obispo de Popayán indica: "Los indios de cuando entraron los españoles eran muchos y grandes señores, porque solo esta provincia de Anserma tenía más de cuarenta mil indios; pero hanse asolado por juicio secreto de Dios, de tal suerte que no hay ochocientos indios, y como la riqueza de las minas es grande, han metido grandes cuadrillas de negros y es de suerte que entre veinte y cuatro vecinos habrá más de mil esclavos en las minas" ("Relación de Popayán”, 1582, por fray Jerónimo de Escobar; en: Cespedesia, revista de la Universidad del Valle, Nos. 45-46, suplemento No. 4, enero-junio de 1983). $\mathrm{Al}$ año siguiente otro español, Francisco Guillén Chaparro, calcula en 1.500 los indígenas de Anserma: "El pueblo [de Anserma] está poblado en una loma no muy grande y no tiene el pueblo más de una calle; hay once encomenderos; habrá en toda la provincia mil y quinientos indios escasos" ("Memoria sobre Popayán, 1583", de Francisco Guillén Chaparro; en: Cespedesia, revista de la Universidad del Valle, Nos. 45-46, suplemento No. 4, enero-junio de 1983).

8 El exterminio generalizado de indígenas en la cuenca del río Cauca, desde Antioquia hasta Popayán, fue denunciado en su tiempo ante la Corte de España por fray Bartolomé de las Casas. Para remediarlo, el mismo religioso propuso reemplazar la mano de obra nativa por negros africanos (Fray Bartolomé de las Casas. Brevísima relación de la destrucción de las Indias [1551]. Buenos Aires, Ediciones Mar Océano, 1953, págs. 98100) 
La antropóloga Inés Lucía Abad Salazar, alumna de Luis Duque Gómez, escribió, en el ya lejano año de 1955, la única obra dedicada de manera específica a los pobladores originarios de esta provincia, titulada, precisamente, Los Ansermas.

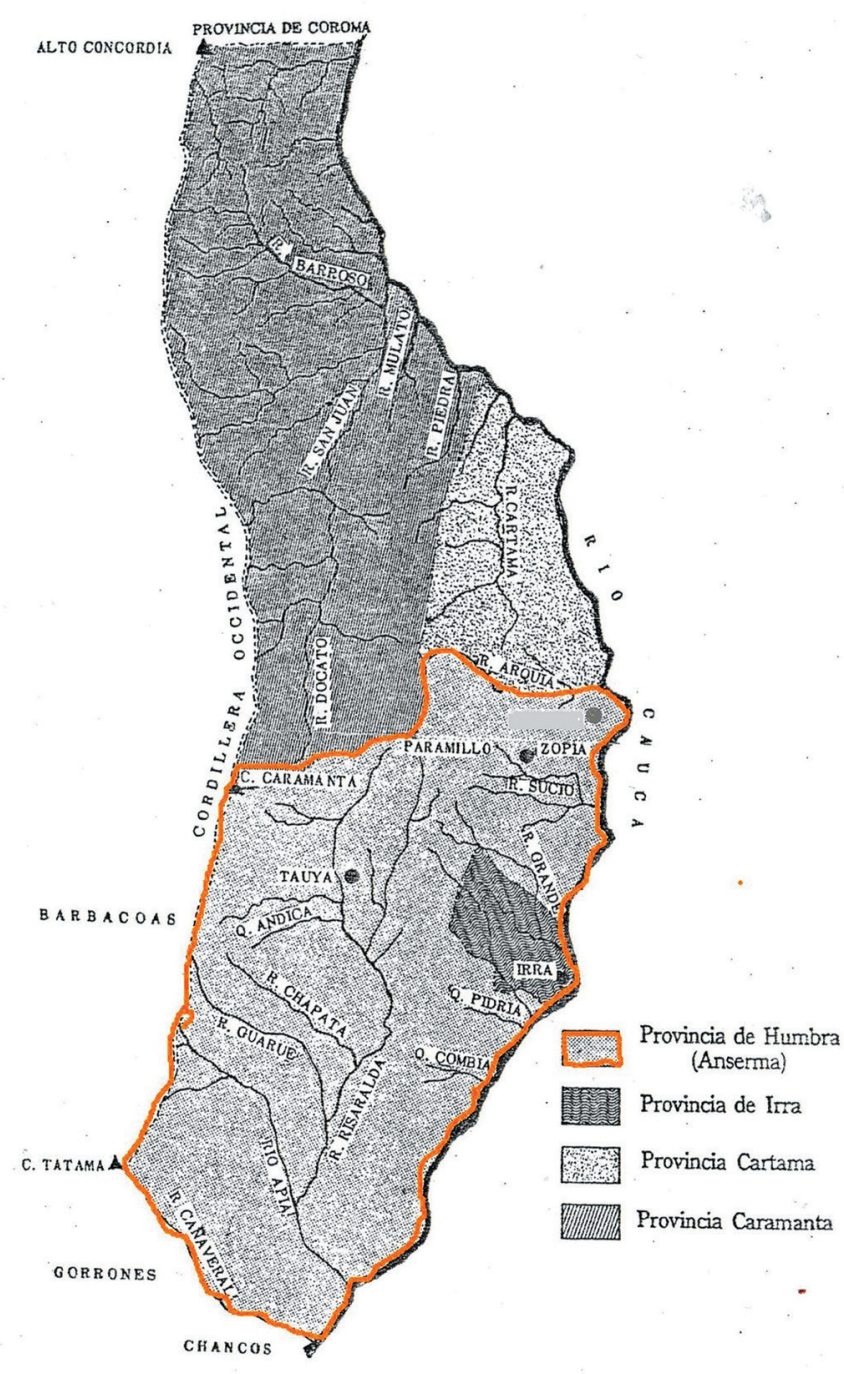

\section{TERRITLRIO HABITADO PDR LDS} ANSERMAS Y SUS COMARCANDS

Mapa del territorio Anserma. Inés Lucía Abad

9 Inés Lucía Abad Salazar. Los Ansermas, Tesis de grado, Bogotá, Universidad Javeriana, 1955. Esta obra fue publicada en 2012 en Bogotá, por el editor Carlos Arturo Ospina Hernández. 
Por medio de los textos de los cronistas la autora reconstruye cómo eran el territorio, la filiación lingüística, la población, la organización social y política, las costumbres, el mundo espiritual, las prácticas de guerra y la costumbre de apoderarse del alma de los vencidos mediante el consumo de su carne. También incluye la conclusión de que la llegada de los españoles interrumpió el proceso de unificación política alrededor de los caciques Ocuzca y Humbruza.

Sobre los caciques existentes en la provincia de Anserma al momento de la llegada de los españoles en 1539, las crónicas mencionan a Ocuzca (al norte de ciudad de Anserma), Humbruza (al sur, hacia el valle de Apía, que era la zona más poblada de la provincia), Cananao (Irra), Ciricha (Pirza), Riteron (Pirza), Cauromá (Caramanta), entre otros.
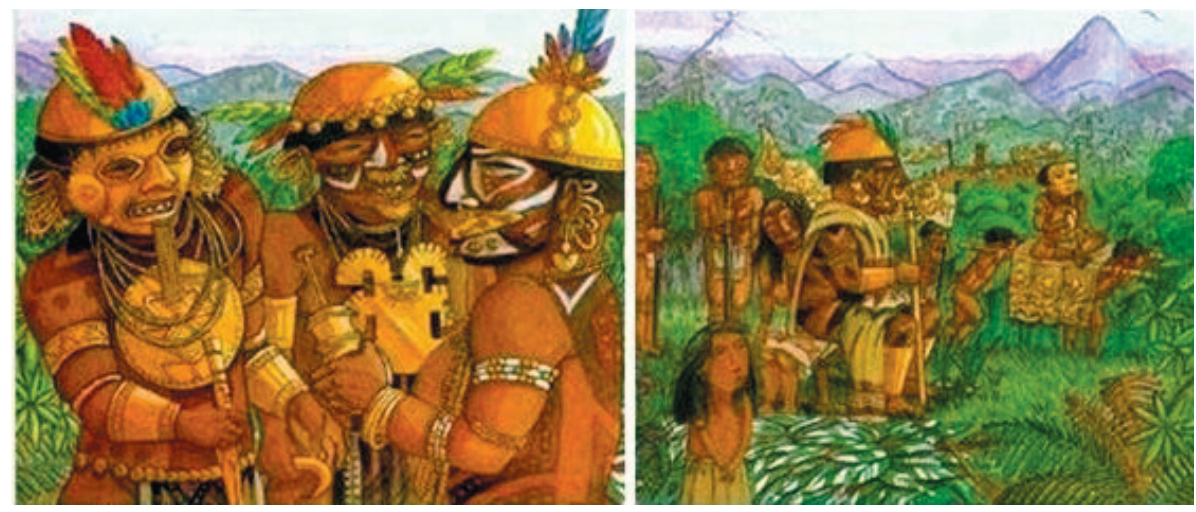

Caciques de la región ${ }^{10}$

Robledo describió así el estado de los cacicazgos:

En esta provincia hay dos señores principales, aunque no les obedece toda la comarca; porque hay otros que casi son tan grandes como ellos. Dícese el uno Humbruza y el otro Ocuzca. El pueblo de Irra, que confina con estos y está tres leguas de la cibdad, es de otra lengua; el señor dél se dice Cananao, sustentábase con todos estos, porque tenía por fuerza un brazo de río por la orilla dél ${ }^{11}$.

Pero también han llegado hasta nosotros los nombres de los caciques de la provincia para 1557, a saber:

10 Ilustración en: María de la Luz Giraldo de Puech y Diana Castellanos. Así éramos los Quimbayas. Bogotá, Fundación de Investigaciones arqueológicas Nacionales, Banco de la República, 2010, disponible en internet. Los dibujos de este libro ilustran con bastante aproximación la sociedad indígena descrita por los cronistas españoles del siglo XVI en los territorios Quimbaya y Anserma, lo que es una herramienta importante para que en los colegios de esta región no se vista a los niños de Aztecas o de Incas, sino como eran.

11 Jorge Robledo: “Descripción de los pueblos de la provincia de Anserma”, 1543. 
Aytamara, hermano del cacique de Mapura.

Azisqunga, señor del pueblo del Piojo y de la provincia de Carambra.

Atucifra, señor de la provincia de Mayma.

Don Francisco, cacique del pueblo de Acochare.

Don Francisco, señor de la provincia de Pirsa.

Guatica, señor del valle de Santa María.

Ocupirama, de las provincias del "Pueblo de la Sal".

Opirama, hijo y heredero "de la cacica, señora de Andica".

Tuzacurara, hermano del cacique de Acochare.

Tuzarma, señor del pueblo de Mapura.

Utayca, señor de la provincia de $\mathrm{Ypa}^{12}$.

\section{La llegada de los españoles}

Los españoles ingresaron al Cauca Medio caldense por el Norte, provenientes de Cartagena, y por el Sur, llegados desde el Perú, por lo que la conquista de esta región fue objeto de una disputa entre las Gobernaciones de Cartagena y del Perú (luego Popayán desde 1540).

12 Juan Friede. Los Quimbayas bajo la dominación española. Bogotá, Talleres Gráficos del Banco de la República, 1963, págs. 82-91. Este listado corresponde al momento de la rebelión de los indígenas del lado Quimbaya en 1557. Cuando los rebeldes se aprestaban a pasar a la provincia de Anserma, el capitán Luis de Guevara, se enteró del plan y mandó llamar a todos los caciques de la jurisdicción y una vez reunidos los apresó "con grillos y cadenas con colleras y cepos, para no perturbar esta villa”. 


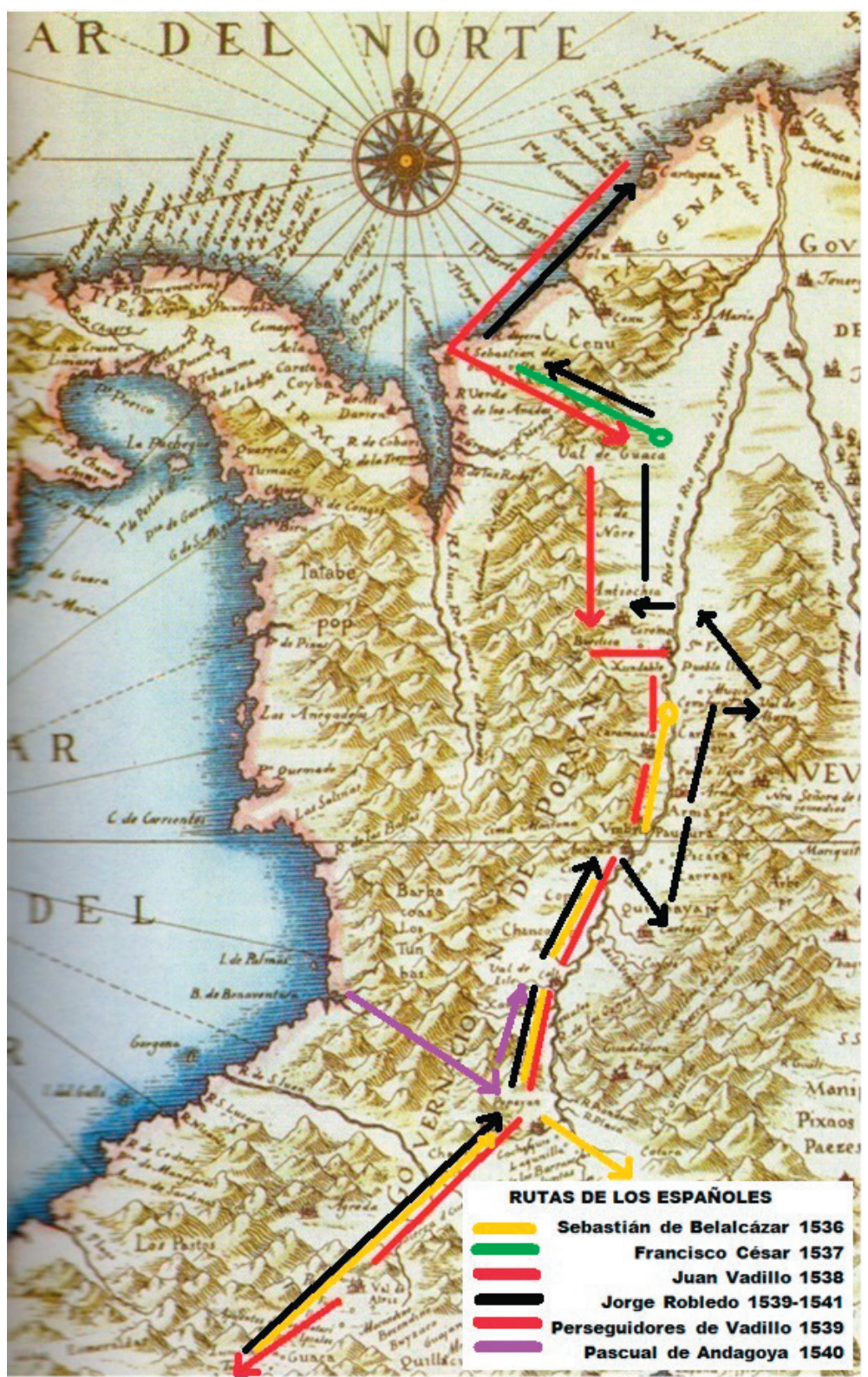

Mapa de las rutas de la conquista del Cauca Medio (1536-1541)

De Cartagena los escarceos de ingreso los hizo el gobernador Pedro de Heredia, quien envió al explorador Francisco César a buscar la fuente del oro de que se surtían los indios del Sinú para su magnífica orfebrería. César entró desde Urabá hasta el valle de Guaca (cerca de Dabeiba, Antioquia), donde supo que más al sur estaban las minas de oro del cerro Buriticá. Entretanto, la Gobernación de Cartagena fue usurpada por el licenciado (juez) Juan Vadillo, a quien César, a su regreso, le dio los informes con 
base en los cuales este licenciado organizó una gran expedición para internarse en Tierra Firme con 200 soldados, 300 caballos, 2 curas y muchos indios y negros de servicio. Esta expedición salió en enero de 1538 de Urabá y llegó en diciembre a Cali, donde se desbarató y sus soldados se pasaron a las tropas del Perú. En el camino, Vadillo halló las minas de Buriticá pero no fundó población en ellas, aunque sí tuvo tiempo de quemar vivo al cacique. También pasó por el actual territorio de Riosucio, donde encontró la aldea de Birú, al parecer sede del cacicazgo Pirza, y donde, según la tradición, le cambió el nombre al río Imurrá por el de río Sucio.

Del Perú vino Sebastián de Belalcázar, de las huestes de Francisco Pizarro. Belalcázar fundó Quitó, Pasto, Popayán y Cali. En 1536 exploró el territorio del norte, al que le dio el nombre de provincia de Anserma, y llegó hasta Supía, de donde se regresó para Cali, aunque sin fundar ciudad. De aquí se fue a buscar "El Dorado" en las tierras del cacique Bogotá. El mando de las tropas de Cali lo tomó Lorenzo de Aldana, agente encubierto de Pizarro, a quien le tocó recibir la maltrecha expedición de Vadillo. Enterado de la riqueza de las minas de Buriticá, Aldana envió al capitán Jorge Robledo a poblar la provincia de Anserma, donde debía fundar una ciudad que se llamara Santa Ana de los Caballeros, que tuviera jurisdicción hasta Buriticá.

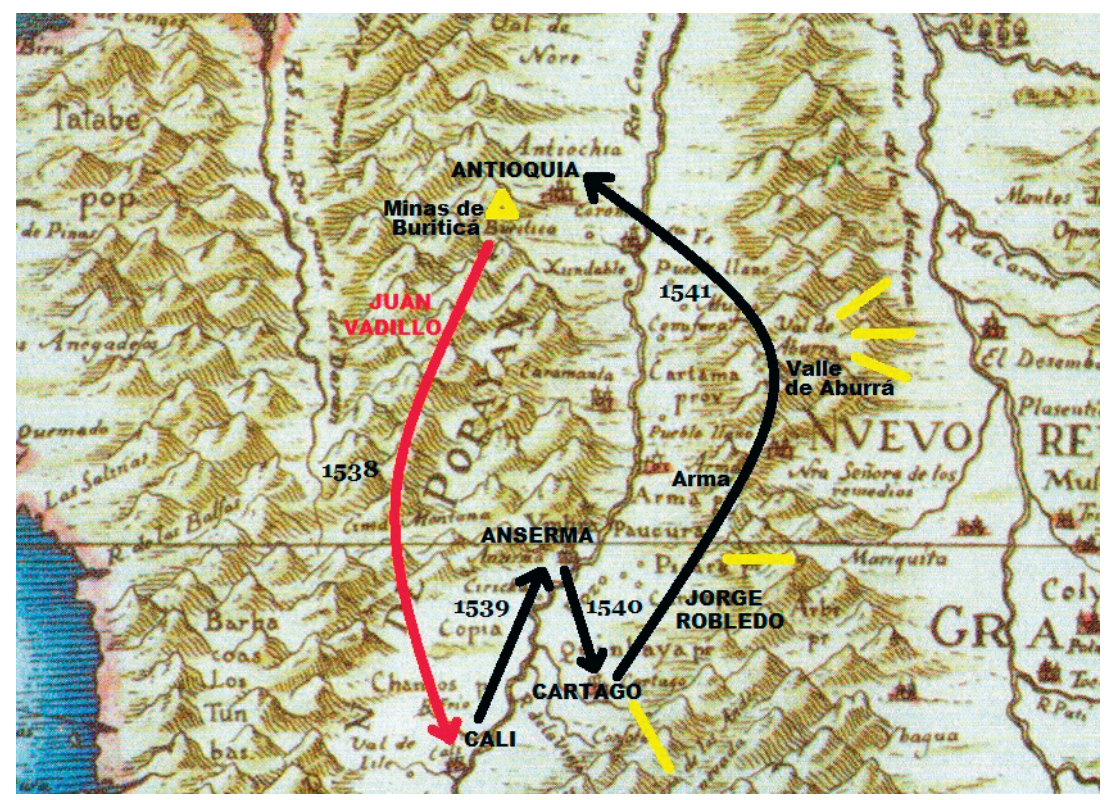

Mapa del ciclo fundacional de las cuatro ciudades del Cauca Medio

Robledo fundó Santa Ana el 15 de agosto de 1539, un año después fundó Cartago (donde hoy es Pereira) y en diciembre de 1541 fundó Antioquia (donde hoy es Peque, en cercanías de las minas de Buriticá). En 1542 Belalcázar envió a Miguel Muñoz a fundar la ciudad de Arma (hoy en Aguadas). Con base en estas cuatro ciudades quedó completa entre 1539 y 1542 la base militar para la conquista de los pueblos 
indígenas del Viejo Caldas y Antioquia, a la vez que la organización administrativa colonial de la zona norte de la Gobernación de Popayán, que se mantendría hasta la Independencia.

\section{La organización colonial}

El fundamento de la organización colonial fue la "Ciudad", la cual no era solo un caserío sino una amplia jurisdicción territorial, por lo cual se trataba de "Ciudades Provincia”. La Provincia de Anserma tuvo en un principio, cuando en 1539 se fundó la ciudad de Santa Ana de los Caballeros, una desmesurada extensión, que por el norte iba hasta Buriticá y al oriente se extendía hasta los nevados de la cordillera central. Pero al fundarse las otras tres ciudades su territorio quedó circunscrito a la margen izquierda del río Cauca, entre los actuales municipios de Ansermanuevo (Valle) al Sur y Marmato (Caldas) al Norte.

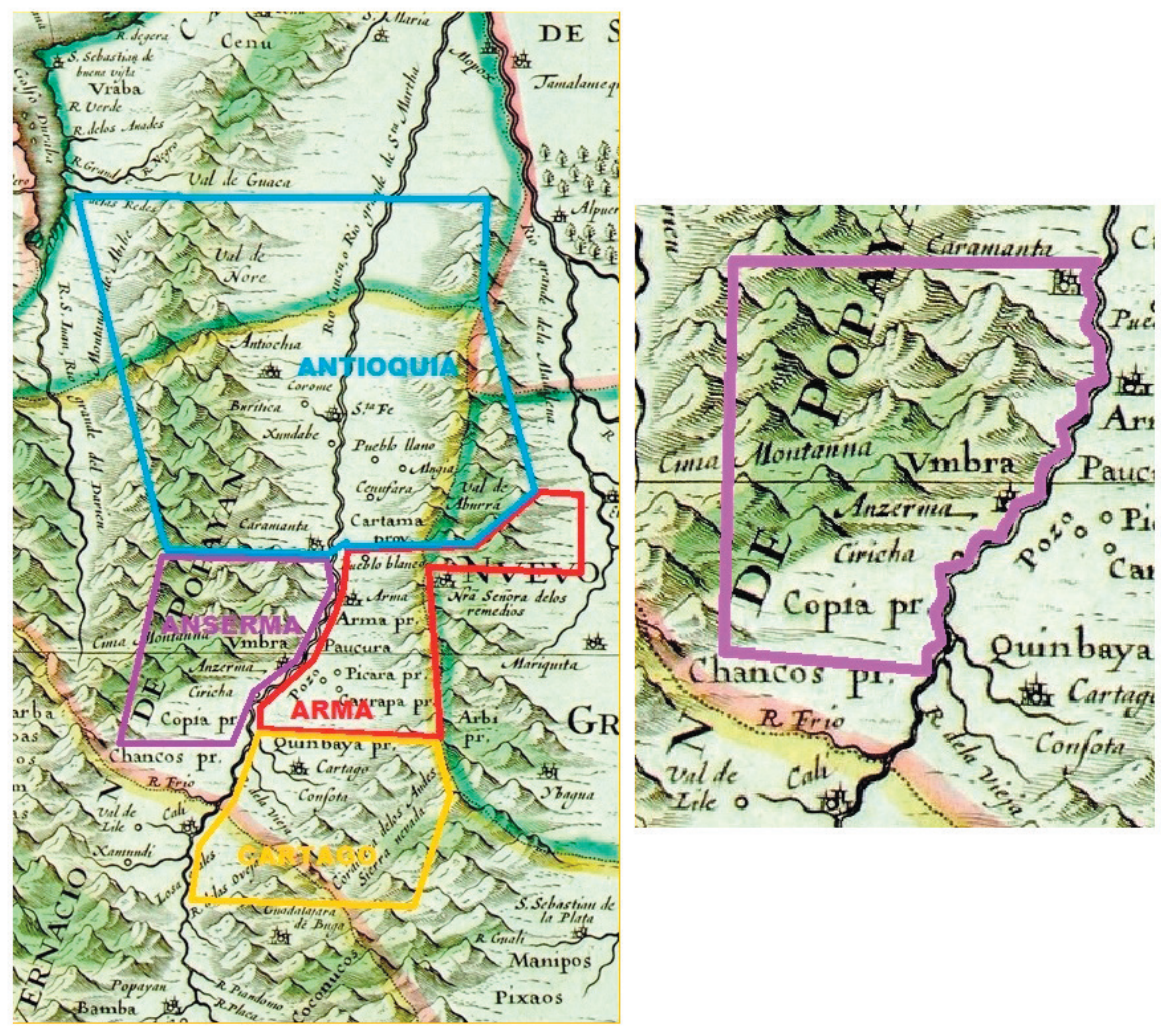

Mapa aproximado de la Provincia de Anserma y su ubicación respecto de las demás provincias del norte de la Gobernación de Popayán para 1542

Otro factor a tener en cuenta es que durante la época colonial se daba el fenómeno de las "Ciudades móviles", o sea, del traslado de un punto a otro de una Ciudad pero dentro de los límites de la respectiva Provincia. De este modo la ciudad de 
Anserma Viejo, fundada en 1539 en la loma de los Umbras, fue trasladada en 1717 para Anserma Nuevo, cerca del río de La Vieja, en cercanías a donde ya se había trasladado Cartago desde 1691.

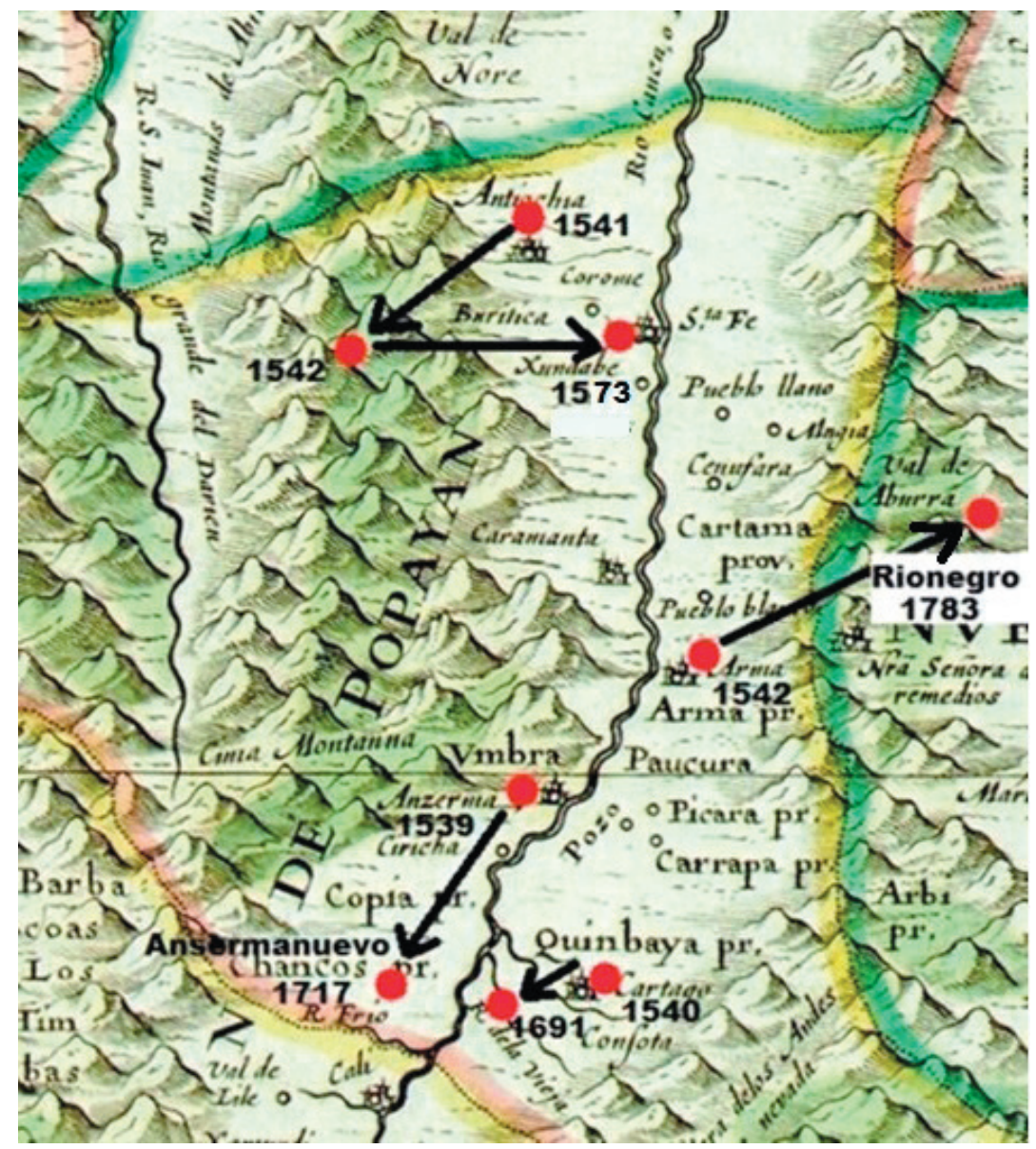

Mapa de los traslados de las Ciudades Robledanas

Durante la Colonia española, el territorio del actual municipio de Riosucio, Caldas, hizo parte de la Provincia de Anserma. Y en la medida que el pueblo de Riosucio (el casco urbano) fue fundado apenas en 1819 , la historia antigua del municipio hay que buscarla enmarcada en la Provincia de Anserma, donde cobran sentido los reales de minas y los pueblos de indios, protagonistas del escenario pre-riosuceño, ya que al interior de las provincias se contaban las Villas, los Reales de Minas, los Pueblos de Indios, los Sitios y los Lugares, todos ellos sufragáneos o dependientes de la Ciudad capital de la Provincia. 


\section{Los Reales de Minas, los Pueblos de Indios y los Resguardos}

En el siglo XVI surgen varias instituciones que serían fundamentales para la territorialidad y poblamiento de la Provincia de Anserma: Los "reales de minas", los "pueblos de indios" y los "resguardos".

Los "reales de minas" eran campamentos mineros autorizados por el rey, donde no sólo se explotaban las minas (oro, plata) sino que se recogía el "quinto real" o regalía, por lo que en dicho lugar tenían asiento funcionarios españoles. También se ubicaban en ellos las parroquias. La mayoría de población, sin embargo, era negra o mulata, pues los blancos españoles vivían casi todos en la Ciudad, ya que estaba prohibido a los encomenderos vivir fuera de ella. Los reales de minas no contaban con "términos" o territorio adscrito. Pero sí contaban con "pueblos de indios" anexos o agregados.

En lo que hoy es Riosucio se estableció desde los primeros años de la conquista, entre 1540 y 1550, el Real de Minas de San Sebastián de Quiebralomo. Un relato posterior se refiere al origen de este nombre ${ }^{13}$ :

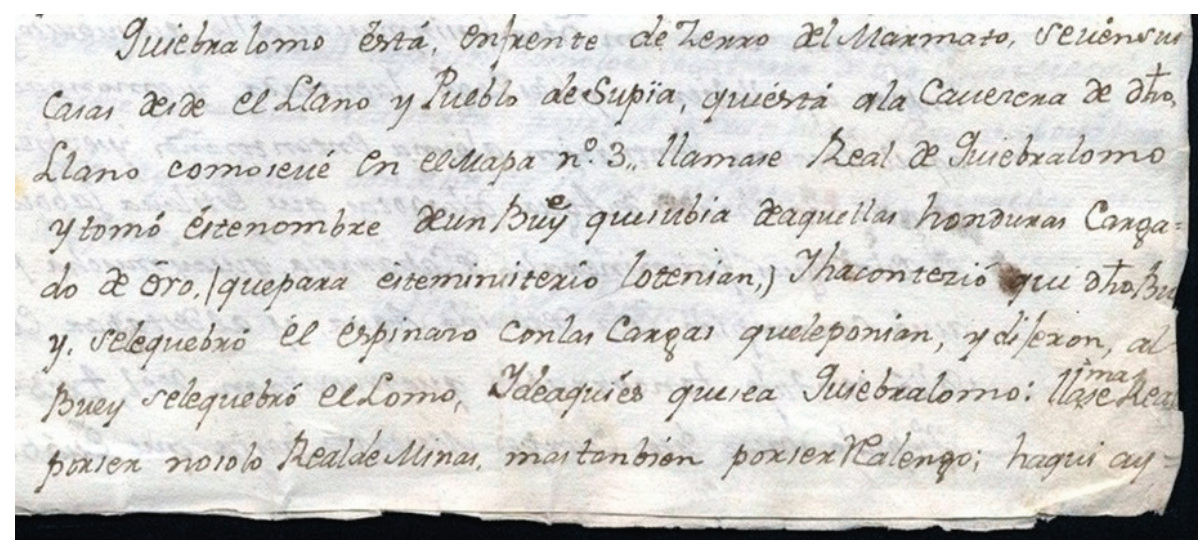

Relato del origen del nombre de Quiebralomo

En general, como corresponde a la codicia que alentó el sueño europeo, en la provincia de Anserma antes que haber resguardos indígenas hubo reales de minas por doquier, como lo señala un documento de 1583:

A otro lado del cerro de Quiebra-Lomo hay otro río que llaman Zupiasí, que está abajo de las minas dichas; ansimismo sacan oro. A dos leguas y media de

13 "Quiebralomo está enfrente del cerro de Marmato. Se ven sus casas desde el llano y pueblo de Supía, que está a la cabecera de este llano como se ve en el mapa $N^{\circ} 3$. Llámase Real de Quiebralomo y tomó este nombre de un buey que subía de aquellas honduras cargado de oro (que para este ministerio lo tenían) y aconteció que a este buey se le quebró el espinazo con las cargas que le ponían, y dijeron: al buey se le quebró el lomo, y de aquí es que sea Quiebralomo: Llámase Real por ser no solo Real de Minas, mas también por ser Realengo" ("Descripción de la Vega de Supía, Provincia de Popayán”. Quito, anónimo, cerca de 1680. Archivo General de Indias, Sevilla, España. Tomado de la página web del AGI). 
este cerro hay otras minas que llaman del Río Grande [río Cauca], tierra muy poblada de muchos cañaverales e pásase un pedazo de montaña; es un cerro altísimo. El oro que aquí se saca es oro el marmato que llaman; tiene de ley nueve, diez y once quilates, que sale destas leyes. E más debajo destas minas hay otras en que también se saca oro más bajo de ley y a un tiro de arcabuz deste cerro del Marmato hay otro cerro [Echandía], asimesmo muy alto, que se saca oro en él por socavones, que así los tenían hechos los naturales cuando los españoles entraron; tiene ley de catorce quilates y a diez y seis quilates. Asimesmo hay otro cerro a tres leguas de las minas de Quiebra-Lomo que llaman el cerro de Picara [al lado del actual Bonafont], sácase oro en él; tiene diez y siete e diez y ocho quilates. A dos leguas deste propio cerro hay otras minas que llaman Mapura; sácase muy buen oro de diez y ocho quilates; hay en este cerro muy pocas aguas e como no llueva sácase poco oro. Una legua destas dichas minas hay otras que se ha sacado y saca bueno oro, que se llaman las minas de Guacayca; tiene de ley veinte y dos quilates y medio y es oro granado. Hay también en el cerro de Quiebra-Lomo minas de azogue [mercurio o plata viva]. Abajo destas minas hay algunas zabanas, donde se cría ganado vacuno e yeguas ${ }^{14}$.

Los "pueblos de indios" fueron mandados formar por el rey Carlos I de España, mediante las cédulas reales del 9 de octubre de 1549, dirigida a Nueva España (hoy México), y del 21 de marzo de 1551, dirigida a Tierra Firme o Nueva Castilla (hoy Colombia).

Estas cédulas fueron dictadas con el fin de liberar a los indígenas del poder de los encomenderos, respondiendo así a las frecuentes quejas de maltratos y esclavización. Las mencionadas cédulas dispusieron que los indios ubicados en distintas encomiendas fueran reunidos en un solo sitio de casas juntas, donde vivieran "en policía" (bajo un orden municipal), nombraran sus propias autoridades (alcaldes, regidores y alguaciles), tuvieran capilla para su adoctrinamiento religioso y se les asignaran "términos competentes" para sus cultivos y ganados.

14 “Memoria sobre Popayán”, 1583, de Francisco Guillén Chaparro, en: revista Cespedesia de la U. del Valle, Nos. 45-46, suplemento No. 4, enero-junio 1983. 


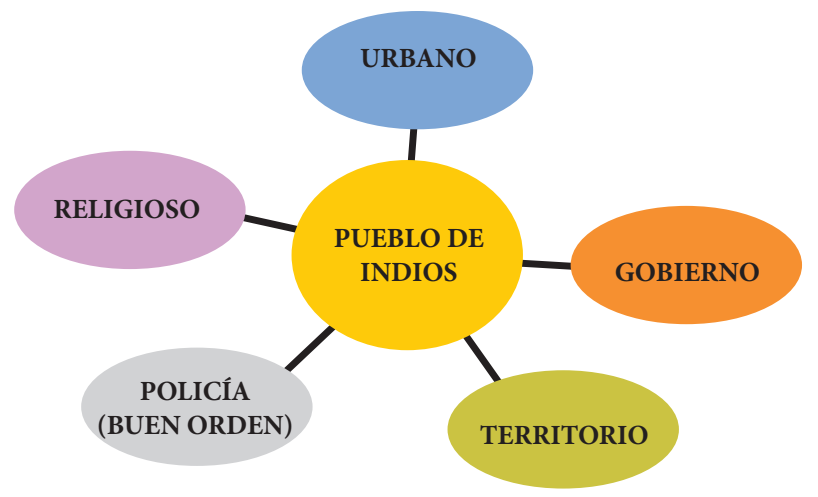

Elementos que integran la institución hispana del Pueblo de Indios

A los pueblos de indios les estaban asociados los siguientes elementos:

a) Un elemento urbanístico: Construir un pueblo de casas juntas, con plazas, calles, barrios, cárcel, coso para animales, tiendas de suministro para los viajeros. Esto casi no se cumplió, pues rompía los patrones ancestrales de asentamiento de los naturales, por lo que en general los nuevos habitantes se dispersaron dentro de los términos del pueblo, aunque hubo alguna centralidad alrededor de la capilla y del sitio de paso en el camino real.

b) Un elemento religioso: La capilla doctrinera.

c) Un elemento político: Un gobierno propio designado por cada parcialidad, con los cargos de alcaldes, regidores y alguaciles, y en varios lugares subsistieron los caciques (los Cabildos son muy posteriores).

d) Un elemento de derecho administrativo: Normas de policía para el buen vivir.

e) Un territorio anexo ("términos convenientes", luego "tierras de Resguardo") para los cultivos, el ganado y la población futura.

De lo anterior se desprende que durante la época de la Colonia la institución indigenista más importante eran los "Pueblos de indios", aunque obviamente el territorio es el sustento físico de la existencia de aquellos, y en este sentido Felipe II dispuso en 1791 que se entregaran tierras tanto a los lugares de españoles como a los indios, dando lugar a los resguardos indígenas como tales ${ }^{15}$.

15 La Cédula de El Pardo del 1º de noviembre de 1591, dirigida a Antonio Gonzáñez, gobernador y presidente de la Real Audiencia del Nuevo Reino de Granada, mandó que la Corona retuviera las tierras de este territorio, previo el reparto de las necesarias para las ciudades y los indios: "reservando ante todas las cosas lo que os pareciere necesario para plazas y ejidos, propios, pastos y baldíos de los lugares y consejos que estén poblados, así por lo que toca al estado presente en que se hallan como al porvenir y al aumento y crecimiento que puede tener cada uno, y repartiendo a los indios lo que buenamente hubiere menester para que tengan en qué labrar y hacer sus sementeras e crianzas, confirmándoles en lo que tienen de presente y dándoles de nuevo hasta los que le fuere necesario" (Indalecio Liévano Aguirre. Los grandes conflictos sociales y económicos de nuestra historia. Tomo I. Bogotá, Tercer Mundo, 1972). 


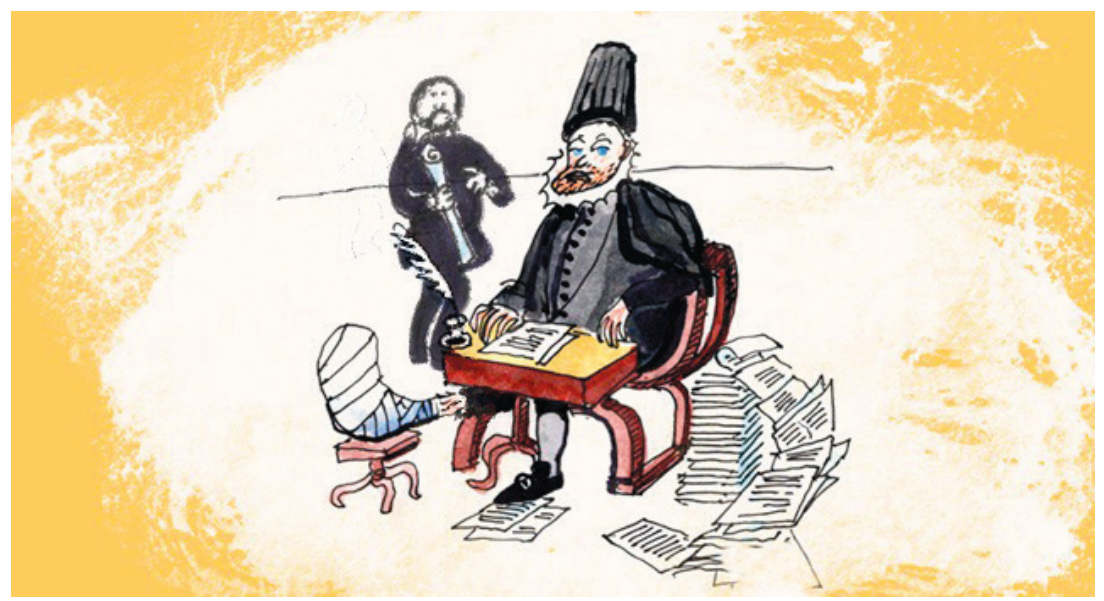

Felipe $I I^{16}$

En la provincia de Anserma los primeros resguardos fueron creados por Pedro de Alvarado en 1597, o por lo menos el de Supía, como se verá en la visita de Lesmes de Espinosa ${ }^{17}$.

16 http://www.bibliotecanacional.gov.co/proyectos_digitales/historia_de_colombia/capitulo3.htm)

17 A este hecho se refiere el novelista riosuceño Rómulo Cuesta en su obra Tomás: "No fue poco el humillo de orgullo que sintió en el corazón al contemplar cómo unas pocas decenas de castellanos (porque de origen castellano se consideraban) pudieron someter en un corto espacio de tiempo y de poner a su servicio como esclavos tribus tan belicosas como los Quinchías y los Pirsas, y, cómo vinieron a considerar estos como gran merced el pedazo de tierra que con el nombre de Resguardos les repartió el Capitán Pedro de Alvarado, de orden de su Majestad Felipe II, allá por los años de 1597, merced hecha a quiénes no tenían antes con qué medir la extensión de sus dominios" (Cuesta, Rómulo. Tomás. Bogotá, Editorial de Cromos, 1923). 
SIGLO XVII 



\section{Visita de Lesmes de Espinosa y Saravia a las provincias de Anserma, Cartago, Arma y Toro (1627). Fundación de los pueblos de indios y los resguardos en la Provincia de Anserma, en especial de La Montaña y la Vega de Supía. Tierras entregadas a los españoles. Las Ordenanzas de Anserma}

\section{Visita de Lesmes de Espinosa y Saravia a las provincias de Anserma, Cartago, Arma y Toro (1627)}

En general, la conformación del territorio del actual municipio de Riosucio proviene de la visita que realizó Lesmes de Espinosa y Saravia, quien fundó los pueblos de indios y creó los Resguardos Indígenas de la zona.

A comienzos del siglo XVII, y con notable atraso respecto de la parte oriental del Nuevo Reino de Granada, la Real Audiencia de Santafé de Bogotá (establecida desde 1550) dispuso la visita de la región noroccidental del país, correspondiente al Cauca Medio antioqueño y caldense. Entre 1614 y 1616 el oidor Francisco Herrera Campuzano realizó la visita de Antioquia, que desde finales del siglo XVI había sido separada de Popayán ${ }^{18}$. Diez años después de la visita de Herrera a Antioquia, el oidor Lesmes de Espinosa y Saravia visitó las provincias de Anserma, Cartago, Arma y Toro, además de las ciudades de "tierra caliente" (Ibagué, Tocaima y Mariquita). Los documentos de esta visita se encuentran en el Archivo General de la Nación, pero aún no han sido publicados ${ }^{19}$.

La comisión de Lesmes de Espinosa y Saravia a las provincias del norte de la Gobernación de Popayán fue aprobada por la Real Audiencia el 16 de noviembre de 1626. Llegó a la provincia de Anserma el 12 de febrero de 1627, permaneciendo en ella hasta el 17 de abril.

18 Juan David Montoya Guzmán y José Manuel González Jaramillo, transcriptores. Visita a la provincia de Antioquia por Francisco de Herrera Campuzano, 1614-1616. Medellín, Universidad Nacional de Colombia, 2010, 458 págs. Colección Bicentenario de Antioquia.

19 AGN VISITAS-CAU:SC.62,1,D.1 /Anserma, Cartago, Arma, Toro: diligencias de visita a minas (1627). Folios: 1-480. Las dos visitas tuvieron como escribano a Francisco Zapata. 
En Anserma el visitador registró la presencia de 18 encomenderos y 538 indios útiles, sin contar a los caciques, a los reservados, a los ausentes, a las mujeres y los niños, que si se contaran (a razón de cinco por cada indio útil) serían en total 2.690 indígenas. También contó 231 negros esclavos en todas las minas de la provincia.

a la [ciudad] de Anserma donde llego a doce de febrero pasado de este presente año y luego publico la visita general de los indios naturales de ella y la hiso y las discreptiones de todos ellos de los encomenderos de la dicha ciudad de Ansserma y sus rreales de minas de oro y su juridicion donde huvo dies y ocho encomenderos y quatro sientos y treynta y tres indios utiles presentes de rrepartimientos y siento y sinco de minas y saca de oro de ellos asi de los que antes avia como de otros que se ausentaron de nuebo que todos unos y otros fueron quinientos y treynta y ocho indios utiles sin sus caciques y rreservados ausentes mugeres y sus hijos y familias $=(\ldots)$

Asimismo se manifestaron y hiso lista de todos los negros esclavos que avia y se hallaron en las dichas minas y saca de oro que tenian los señores de quadrillas de ellos con distincion en cada Real que aviendo hecho rregulacion de los dichos negros esclavos consto que fueron duçientos y treynta y uno [al margen: negros 231] ${ }^{20}$

\section{La fundación de los pueblos de indios y los resguardos en la Provincia de Anserma, en especial de La Montaña y la Vega de Supía}

Como se dijo atrás, la historia de la conformación del territorio de Riosucio no se comprende sólo con base en el mapa del actual Municipio, sino que hay que remitirse al territorio de la provincia de Anserma, lo que se pone en evidencia al observar el ordenamiento que de ella hizo el visitador Lesmes de Espinosa, quien trasladó no sólo indios sino también españoles de un lado a otro de la provincia, particularmente en la Vega de Supía.

La labor de Lesmes de Espinosa obedeció al doble objetivo de fortalecer la ciudad de Anserma (Viejo) como capital de la provincia y residencia de los encomenderos, y de organizar la zona minera del norte de la provincia, para lo cual dispuso dos grandes ordenamientos:

Por el primero se concentró toda la población indígena de la zona sur de la provincia (Chatapa, Usma, Apía, Supinga, Andica, Cumba, Guacaica, Curumbi y La Provinçia, Tabuya y El Peñol, que sumaban 166 indios útiles) alrededor de la ciudad de Anserma, en el Resguardo Tabuyo (hoy vereda San Pedro, Anserma, Caldas), y se pusieron a su servicio los pueblos cercanos de Guática, Tusa y La Sabana.

20 Resumen de la visita de Lesmes de Espinosa (Ibagué el 20 de mayo de 1627), transcrito por José Manuel González Jaramillo, y presentado en Riosucio el 22 de septiembre de 2013 en el Foro "475 años del nombre de Riosucios" (inédito). 
Por el segundo ordenamiento Lesmes de Espinosa fundó u organizó los pueblos de indios del norte ansermeño, los cuales se agregaron o anexaron a los reales de minas de Opiramá, Mápura, Buenavista (cerro Batero), Quiebralomo, Supía y Marmato, estando el nuevo pueblo de La Vega de Supía destinado a ser el más importante, como lo expresara el propio Lesmes:

en esta poblazion y doctrina de la Bega quedo actualmte ocupado y con deseo de que sea la mejor de toda esta Probinzia porque me persuado que assi ynporta al serbizio de Dios Nro Sr y al aumento de los Reales Quintos ${ }^{21}$.

A su salida de la provincia, Lesmes dejó establecidos los pueblos de indios de La Montaña, La Vega, Marmato, Opirama, Tabuya, Guatica, Savana y Tusa, con la orden imperiosa de no trasladarlos sin autorización de la Real Audiencia:

1 Primeramente ordeno y mando que el governador ni su lugarteniente ni otras qualquier justicia no de liçençia para que los yndios que quedan poblados en los pueblos de La Montaña, La Vega, El Marmato, Opirama, Tabuya, no las poblaciones de Guatica, la Çavana y Tuça muden los asientos en que quedan ni los encomenderos //[fol 312v]// los puedan mudar en todo ni en parte ni los yndios de su autoridad lo puedan haçer porque qualquier mudança en caso que por algunos suçesos convenga esta se a de haçer con orden y por mandado de los señores presiedente y oydores de la Real Audiencia del Nuevo Reyno de Granada y no de otra manera ${ }^{22}$.

En otro documento el secretario del visitador hace una descripción de las cuatro nuevas poblaciones fundadas en la zona norte de la provincia por Lesmes de Espinosa y Saravia, información sintetizada en el siguiente cuadro:

\begin{tabular}{|l|l|l|l|l|}
\hline \multicolumn{1}{|c|}{ Población } & \multicolumn{1}{|c|}{ Indios } & Total indios & \multicolumn{1}{|c|}{ Encomiendas } & Esclavos \\
\hline Real de Minas de Marmato & 11 útiles & 55 & $\begin{array}{l}\text { Catalina Cano } \\
\text { Cristóbal Blandón }\end{array}$ & 70 \\
\hline $\begin{array}{l}\text { Pueblo de indios de La } \\
\text { Montaña }\end{array}$ & $\begin{array}{l}55 \text { útiles } \\
\begin{array}{l}\text { reservados } \\
168 \text { familia }\end{array}\end{array}$ & 226 & $\begin{array}{l}\text { Francisco de } \\
\text { Herrera }\end{array}$ & 51 \\
\hline Pueblo de indios La Vega & 80 útiles & 400 & & 116 \\
\hline Real de Minas Quiebralomo & 20 útiles & 100 & & \\
\hline
\end{tabular}

Cuadro resumen de las poblaciones fundadas por Lesmes de Espinosa en el norte de la provincia de Anserma ${ }^{23}$

21 Documento sin título, 20 de marzo de 1627, transcrito por José Manuel González Jaramillo, y presentado por éste en Riosucio, Caldas, el 22 de septiembre de 2013 en el Foro "475 años del nombre de Riosucio".

22 Ordenanzas de Anserma (Anserma, 14 de abril de 1627), documento transcrito por José Manuel González Jaramillo. 
El 15 de marzo de 1627, como se mencionó, el oidor Lesmes de Espinosa fundó el pueblo de indios de La Montaña, con los naturales de la encomienda de Francisco Llorente, y le hizo entrega al cacique Sebastián, en calidad de Resguardo, de las tierras que siempre habían ocupado:

En el repartimiento de la Montaña de la encomienda de Francisco Herrera, jurisdicción de la ciudad de Anserma, a 15 días del mes de marzo de 1627 años, el señor doctor Lesmes de Espinosa y Sarabia, del Consejo de su majestad y su oidor más antiguo de la Real Audiencia del Nuevo Reino de Granada y visitador general de los partidos de Anserma y Cartago y los demás de su comisión, habiendo visto por vista de ojos las tierras y montañas, sitio y asiento de este pueblo, y que está informado es sano y de buen temple, fresco y de buenas aguas, y que los indios están contentos y se huelgan de quedarse ahí por hallarse bien: mandaba y mando que estos indios de la Montaña, así de repartimiento como de mina se queden y sean poblados en este pueblo de la Montaña donde están, los cuales, con los demás que en cualquier manera se agregaren a estos de estos términos de la Montaña, hagan población y doctrina 24 .

De La Montaña, Lesmes de Espinosa se trasladó a inspeccionar las tierras de la Vega de Supía:

VISTA DE LOS HATOS DE LA VEGA. el 20 de marzo de 1627 años, el dicho oidor visitador partió de los aposentos de Francisco Llorente para ver por vista de ojos los hatos de ganados mayores que hay en la Vega y su contorno, y habiéndose llegado a ella (...) se vio el resguardo de los indios de Supía la Baja que le dio Pedro de Alvarado, Juez de Tierras, y estancias, y se vio ocularmente con vista de ojos los términos y tierras de él, y se vio la ramada y bohío que es grande y buena para la iglesia de la nueva población de la Vega ${ }^{25}$.

Y el 22 de marzo procedió a entregar dichas tierras de La Vega a los pueblos Sonsón, Supía, Pirza y Umbra:

En los aposentos de Francisco Llorente, jurisdicción de Anserma, a 22 días del mes de marzo de 1627, el señor doctor Lesmes de Espinosa y Sarabia del Consejo de su majestad y su oidor más antiguo de la Real Audiencia del Nuevo Reino de Granada y visitador general de los partidos de Anserma y Cartago y los demás de tierra caliente, dijo que su merced ha mandado reducir y poblar en el nuevo sitio de la Vega los indios de Sonsón que se trajeron de la

24 Transcripción tomada del libro Los títulos de San Lorenzo. publicado en 2010 por el Cabildo Indígena de San Lorenzo.

25 Cabildo Indígena de San Lorenzo. Los títulos de San Lorenzo, 2010. Habría que averiguar si en esta visita se crearon otros resguardos 
jurisdicción de la ciudad de Arma, y los de Supía la alta, y los indios de Supía la baja y los de Pirza y Umbría, para que sean doctrinados todo el año, y para que con efecto se ejecute [haga] esta población y los ganados se echen fuera y se demuelan los hatos donde están ${ }^{26}$.

La distribución específica de cada uno de estos pueblos a lo ancho de la Vega es asunto debatible, debido a la dificultad de identificar hoy los mojones antiguos. Cuando llegó Lesmes de Espinosa ya los indios de Supía tenían resguardo, entregado por Pedro de Alvarado (en 1597), que les fue ratificado por el oidor, sólo que por petición de los mismos Supías, ubicó unos en la parte alta (al pie del cerro Tacón y donde hoy queda el casco urbano) y a otros en la parte baja (el llano y hasta Marmato).

Sobre los Sonsones el escribano de Espinosa consignó:

Mando sacar de una rancheria que avia en la juridicion de la ciudad de Arma unos indios que se llamavan de Sonson que estavan retirados y oprimidos y ser pocos los demas de ella naturales de otras partes casados y enparentados mucho tienpo a con los de Sonson y los mando poblar y reducir a la dicha nueba ppoblacion de La Vega con otros para que sean dotrinados y por no tener encomendero los puso en la Corona Real de Su Magestad ${ }^{27}$

Respecto de los Pirzas, éstos habían sido trasladados en los días anteriores de su territorio ancestral en el valle del río Imurrá (o río Riosucio) para la Vega de Supía, pues Lesmes de Espinosa ya había visitado el 12 de marzo el pueblo de Pirza, de la encomienda de María Redondo. En esta visita, el oidor reunió a todos los indígenas y les informó que por orden del rey los iba a trasladar para la Vega de Supía con el fin de que formaran un pueblo con otras tribus y tuvieran una mejor doctrina en el cristianismo. Sobre este traslado se conoce la declaración que le tomó el visitador al indio Marcos, 30 años de edad, ladino y mandador del pueblo de Pirza:

A la cuarta pregunta dijo que habiendo de ser poblados y reducidos estos indios de Pirsa con otros para que sean dotrinados, como el señor oidor se lo ha dado a entender, estarán bien en la Vega y Llano donde hay buenas tierras para sus labranzas y sementeras y es tierra tenplada y sana y con muchas aguas y leña y pasto para sus bestias y ganados y se juntarán con los indios de Supía la Baja y con los de Supía la Alta porque son amigos y conocidos y que desde el dicho pueblo de Pirsa a la dicha Vega habrá una legua de camino y que todos los dichos indios son ladinos y hablan la lengua española y esto responde ${ }^{28}$.

26 Transcripción tomada del libro Los títulos de San Lorenzo.

27 Resumen de la visita de Lesmes de Espinosa. Ibagué 20 de mayo de 1627 (citado).

28 Visita al pueblo de Pirza, transcrita por José Manuel González Jaramillo (inédito). 
Uno de los documentos de la visita contiene la relación de cuáles fueron las tierras que se les entregaron en calidad de resguardo a los indígenas de cada uno de los pueblos instalados en la Vega de Supía. También hay disposiciones sobre tierras comunales (ejidos) y sobre el orden en que debían ubicarse las cuatro naciones indígenas en la iglesia:

Fol 140v, Repartición de tierras

A los yndios de Sonson se le señala la estançia de Miguel Morillo Labrador $[\ldots]$ para $q$ las rrepartan entre si y sus familias [...]

A los yndios de Supia la Alta y Arquia les da señala y adjudica todas las tierras q tenian y poseian y an goçado y poseido antes de este reduçion y poblaçion y an tenido por terminos y rresguardos y se les ampara en ellos y en sus huertas çercados y platanares yucales y arboles frutales[...]

A los yndios de Supia la Baja les deja anpara y adjudica en todas las //[Fol 141r]// tierras y rresguardos y sus terminos que an tenido goçado y poseido hasta el dia desta rreduçion hasta la roça que actualmente tiene el cazique don Gaspar y de alli corriendo la loma arriba atravesando el camino rreal q va a el rio Grande $[\ldots]$ y assi mismo les ampara en los sitios de su pueblo viejo casa huertas y çercas platanares yucales y batatales[...]

A los yndios del pueblo de Pirsa se les da y señala desde la dha rroza del cazique don Gaspar [...]

Y el potrero grande q esta linde con las tierra señaladas a los yndios de Sonson son vertientes de la dha loma queda por comunidad a todos los dichos quatro repartimientos en que ençierren sus bestias y ganados[...]

Y toda la tierra que ay en el llano de la Vega //[Fol 141v]// por bajo del dho pblo nuevo hacia el camino de Pirsa se señala a todos los dhos ynos de sus nombrados para exido comun de sus bestias y ganados[...]

Y las sobras de tierras que ay en la dha nueva poblaçion se aplican a cada uno de los dhos pueblos conforme estan plantados y situados.

Y se manda a todos los dhos yndios que en los asientos de la dha yglesia guarden la orden q por Su Mrd se a dado que es que a la mano derecha de las puertas que estan frontero una de otra hazia el altar se sienten los yndios de Supia la Baja y al lado yzquierdo los de la Alta y de las puertas abajo los yndios Pirsas y Unbrias al lado derecho y los ynos de Sonson a la yzquierda $[\ldots]^{29}$ 


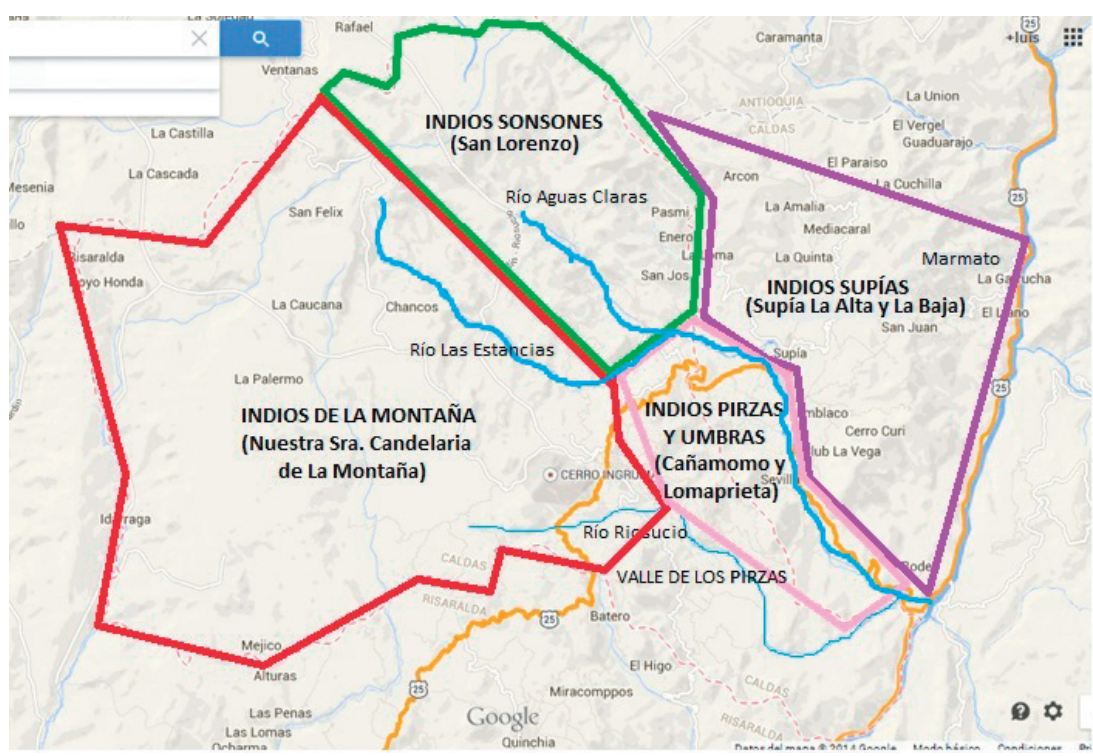

Mapa aproximado de la entrega de tierras a los indígenas en la Vega de Supía por Lesmes de Espinosa, Año de 1627

En el año 1990 las comunidades de Riosucio tuvieron acceso a una copia de esta relación, expedida el 4 de octubre de 1978 por el director del entonces Archivo Nacional, localizada en el archivo del Juzgado Civil del Circuito de Riosucio. Este documento fue protocolizado en la Notaría Única de Riosucio el 21 de noviembre de 1990, mediante la Escritura Pública No 600 de 1990, por los gobernadores de los Resguardos de La Montaña (Miguel Antonio Largo Pescador), Cañamomo Lomaprieta (Faustino Rotavista) y San Lorenzo (Darío Bañol) ${ }^{30}$.

\section{Las tierras entregadas a los españoles}

Como en las tierras que se le entregaron a los indígenas en la Vega de Supía estaban establecidos varios españoles con sus hatos de ganado, Lesmes de Espinosa ordenó su desalojo y el consiguiente traslado para el Valle de los Pirzas:

...estando presentes los dichos Cristóbal Sánchez Hellín y Francisco Romero, el dicho señor oidor les preguntó que cuyo era el ganado que había vacuno en la dicha vega, y respondieron que era de los susodichos y les mandó que dentro de tercero día lo saquen de ahí y lleven al valle de Pirza, en las tierras que han de dejar los indios Pirzas, que en ellas les ofrece en nombre de su majestad, recompensa de las que les quita para hacer la dicha población ${ }^{31}$.

30 Esta escritura se encuentra publicada en el libro Los títulos de San Lorenzo (Cabildo de San Lorenzo, 2010).

31 Los títulos de San Lorenzo, citado. 
Esto explica por qué, un siglo después, en 1759, cuando un grupo de indígenas del pueblo de La Montaña quiso asentarse en el Valle de los Pirzas le debieron comprar los terrenos a la española Catalina Jiménez Gamonares.

\section{Las Ordenanzas de Anserma}

La labor de Lesmes de Espinosa no se limitó a la fundación de los pueblos de indios y a la entrega de los resguardos. La visita se ocupó de la organización de todos los aspectos de la provincia. A este efecto el visitador expidió el 14 de abril de 1627 las "Ordenanzas de Anserma" para el gobierno, no solo de los indios sino también de la "República de españoles", e igual expidió ordenanzas sobre minas:

Nombro persona por protector y administrador general de los indios de la dicha ciudad de Anserma y hiso ordenansas para su buen govierno y bien comun de la republica [testado: pañoles] de los españoles y les proveyo del servicio conpetente de indios mitaayos y consertados e indios de servisio [...] Asimismo hiso ordenansas para el buen govierno de las dichas minas y saca de oro de ellas en que se an de ocupar por mita los indios [...] y las dichas tasas y ordenansas fueron leydas publicadas y notificadas y se asentaron en el libro del cavildo de la dicha ciudad de Anserma para que fuesen notorios y se guardasen y de algunos de ellas dichas ordenansas y otras cosas se apello por algunas de las partes para la dicha Real Audiencia y sin envargo los mando executar $=$ Nonbro por executor de las dichas ordenansas y tasas al teniente de governador de la dicha ciudad de Anserma y en su ausencia al alcalde ordinario mas antiguo de ella y en ausencia de amvos al otro alcalde ordinario de modo que solo aya un executor y no mescla de muchos jueses ques causa de grandes incovinientes para los indios [repetido: para los indios] [... $]^{32}$.

Para el momento actual tiene gran importancia la primera de las disposiciones de estas ordenanzas, que prohibió a las autoridades civiles, a los encomenderos, a los curas y a los caciques trasladar los pueblos de indios fundados por Lesmes de Espinosa sin orden de la Real Audiencia, aboliendo así la costumbre de los ochenta años anteriores, la cual fue una de las causas de la desaparición física o cultural de muchas comunidades:

1 Primeramente ordeno y mando que el governador ni su lugarteniente ni otras qualquier justicia no de liçençia para que los yndios que quedan poblados en los pueblos de La Montaña, La Vega, El Marmato, Opirama, Tabuya, no las poblaciones de Guatica, la Çavana y Tuça muden los asientos en que quedan ni los encomenderos //[fol 312v]// los puedan mudar en todo ni en parte ni los yndios de su autoridad lo puedan haçer porque qualquier mudança en caso que por algunos suçesos convenga esta se a de haçer con orden y por mandado 
de los señores presiedente y oydores de la Real Audiencia del Nuevo Reyno de Granada y no de otra manera - so pena que si el governador teniente y justiçias lo hiçieren y permitieren en qualquier manera se despachara a su costa juez de la dicha Real Audiencia con dias y salarios y se proçedera contra ellos a execuçion de otras penas - y el encomendero que los mudare yncurra en privacion de la encomienda la qual por el mismo hecho la declaro por vaca y desde luego la pongo en la Real Corona y mando que constando de los susodicho los ofiçiales reales de la çiudad de Cartago pongan en ella administrador para que recoja las demoras y tributos y los metan en la Real Caxa por quenta de Su Magestad y dello den aviso a los dichos señores presidente y oidores y se ruega y encarga a los padres doctrineros que al presente son y adelante fueren no yntenten haçer mudança de los yndios poblados y agregados a sus doctrinas sin la dicha orden y liçençia de los dichos se;ores presidente y oidores y los yndios que se ausentares o despoblaren de su autoridad sean presos y detenidos en la prision y en el çepo diez dias y le sean dados en el rrollo çinquenta azotes publicamente para escarmiento de otros y si fuere casique sea privado de su cazicazgo ${ }^{33}$.

Esta ordenanza les dio estabilidad a los pueblos de indios de La Montaña, Cañamomo y San Lorenzo, lo que les permitió mantenerse durante toda la época de la Colonia y pasar a la República conservando su integridad territorial y poblacional. Los Supías no corrieron con igual suerte, o al menos no se conoce mucho qué pasó con los indios de Supía la Alta y Supía la Baja durante el resto de la Colonia, aunque se sabe que en 1819, el mismo año de la fundación de Riosucio, un derrumbe del cerro Tacón sepultó el pueblo de Supía La Alta. 

SIGLO XVIII 

Intento fallido de trasladar a los indios de Lomaprieta para Supía la Baja en 1701. El pueblo de Cañamomo le gana el sitio de Riosucio al pueblo de La Montaña en 1721. En 1751 el pueblo de La Montaña recupera el sitio de Riosucio. En 1758 se declara la unión de los pueblos de Cañamomo y Supía la Baja. Los indígenas de La Montaña compran los terrenos de Pirza en 1759. Los quiebralomeños se introducen al sitio de Riosucio. Cómo era el territorio de Riosucio en 1771.

1. Intento fallido de trasladar a los indios de Lomaprieta para Supía la Baja en 1701

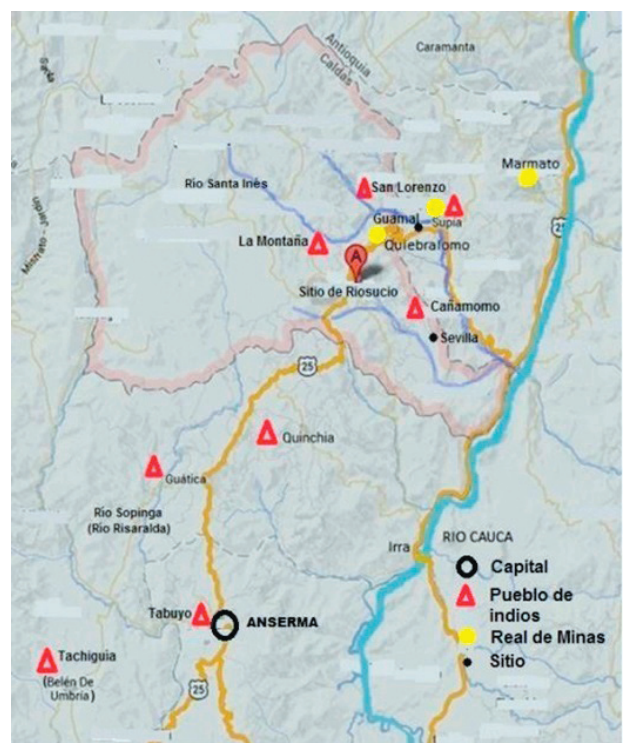

Mapa aproximado de la zona norte de la Provincia de Anserma en el siglo XVIII

El nuevo pueblo de Supía mandado construir por Lesmes de Espinosa en 1627 a costa de los encomenderos parece que no se construyó, o por lo menos no en su concepción original, con iglesia donde se sentaran de manera separada las cuatro 
tribus mandadas poblar en él ${ }^{34}$. En su lugar, cada tribu construyó su pueblo por aparte. Los Supías ubicaron su pueblo al pie del cerro Tacón. Los Pirzas se ubicaron en el sitio conocido con el nombre de "Partido de Lomaprieta" y los Umbras como que se fueron para otra parte, porque setenta años después de la visita de Lesmes de Espinosa el partido de Lomaprieta estaba habitado por las parcialidades de Pirzas y Cumbas. Este dato se conoce porque está incluido en una demanda que puso en 1701 el protector de indios ante el virrey de Santafé contra el teniente de la ciudad de Anserma por estar éste trasladando a los indios de Lomaprieta para la hacienda de su papá en el pueblo de Supía la Baja:

don Antonio de la Lana, y censarelator de la Real Audiencia y protector nombrado de los naturales de este reino por los indios de Lomaprieta en la jurisdicción de la ciudad de Anserma, Gobierno de Popayán, dice le informan que se compone dicho pueblo de Lomaprieta de dos parcialidades, la una llamada Pirza y la otra Cumba y todos se llaman Curicamayos, el cual dicho pueblo lo pobló de dichas parcialidades nuestro oidor visitador que fue de aquella provincia don Lesmes de Espinosa y Saravia, por esta Lomaprieta, media legua distante del Real de Minas de San Sebastián de Quiebralomo que dicha población la hizo por el año de mil setecientos [seiscientos] y veinte y siete. ${ }^{35}$.

Las que sí se cumplieron fueron las "Ordenanzas de Anserma", porque en el mismo expediente consta que los indios de Lomaprieta fueron obligados a trasladarse para Supía la Baja, pero ante el reclamo de los alcaldes indígenas la Corona lo impidió, ordenó el retorno de los afectados y sancionó al teniente de la ciudad de Anserma que había cometido la arbitrariedad:

Pedro Manzano de Leanos y Valdés, teniente general de la ciudad de Anserma [nortificó] a los indios curicamayos dejasen el sitio de la Lomaprieta, en que les había puesto nuestro oidor visitador, derrumbándoles tres casas, mandándoles se fuesen a poblar el pueblo de San Lesmes de Supía la baja, y aunque dichos indios le replicaron a dicho teniente que eran nacidos y criados todos en dicho pueblo de Lomaprieta y que no habían conocido otro pueblo, en donde habían sido amparados por todos los gobernadores y que habían sido recomendados

34 En el siglo XVIII aparecen memoriales firmados en La Vega y también en la agregación de Sevilla, que es un pueblo de vecinos, es decir, de blancos.

35 Apartes de la petición de Antonio de la Lana, relator de la Real Audiencia de Santafé, al Virrey para que ordene que los indios Curacamayos (Pirzas y Cumbas), que fueron trasladados al pueblo de San Lesmes de Supía la Baja por Pedro Manzano de Leanos y Valdés, teniente general de la ciudad de Anserma, sean retornados al sitio de Lomaprieta, donde fueron poblados por el visitador Lesmes de Espinosa y Saravia en 1627 (Santafé, 20 de mayo de 1701). Archivo Nacional. Escritura No 263 de 1903 de la Notaría de Riosucio. Valgan dos anotaciones: que "Curicamayo" no es una etnia sino una palabra derivada del Quechua que significa indios de minas o expertos en el laboreo de minas de oro, y que los Cumbas dejaron de existir como pueblo difereciado desde el siglo XVIII, mezclándose con los Pirzas en el pueblo de Cañamomo, denominación que tampoco es un vocablo originario. 
al ayudante Antonio de Serqueda, y por su fin y muerte, en Bernabé Benítez, su yerno, y por la de éste estaban pagando sus tributos con toda puntualidad, a vuestra real persona, y que nunca habían conocido por su pueblo al dicho de Supía baja, ni a su encomendero, y sin embargo de estas reconvenciones pasó a derribarles dichas tres casas, mandándoles se fuesen a poblar a dicho pueblo de Supía baja, de donde es encomendero el maestro de campo Diego Manzano, padre de dicho teniente, y habiendo ido contra su voluntad algunos a dicho pueblo de Supía, que dista de dicha Lomaprieta cerca de dos leguas, con la circunstancia de haber de pasar dicho río de Supía, que es muy caudaloso, y el temple de dicho pueblo de Supía muy cálido y el de Lomaprieta muy templado y que habiendo llevado a Pascual Lengua y sus hijos al otro pueblo de Supía, experimentaron el mal temple, pues luego les dio el ataque de fríos y calenturas, que se halló precisado a volverlos al otro pueblo de Lomaprieta, en que se conoce la mala calidad del temple del otro pueblo de Supía y el exceso que cometió dicho teniente de haber pasdo [sic] a querer mandar otro pueblo de Lomaprieta, sin mandárselo nuestra Alteza en dicha real provisión, por lo cual pide el protector sea castigado severamente y más cuando está prevenido por ley real que de ninguna manera sean mudados los indios de tierra fría a templada o a la caliente, y por otro si manda que ningunos corredores [sic] tenientes ni alcaldes ordinarios muden pueblo alguno de indios sin expresa licencia de nuestra real persona ${ }^{36}$

\section{El pueblo de Cañamomo le gana el sitio de Riosucio al pueblo de La Montaña en 1721}

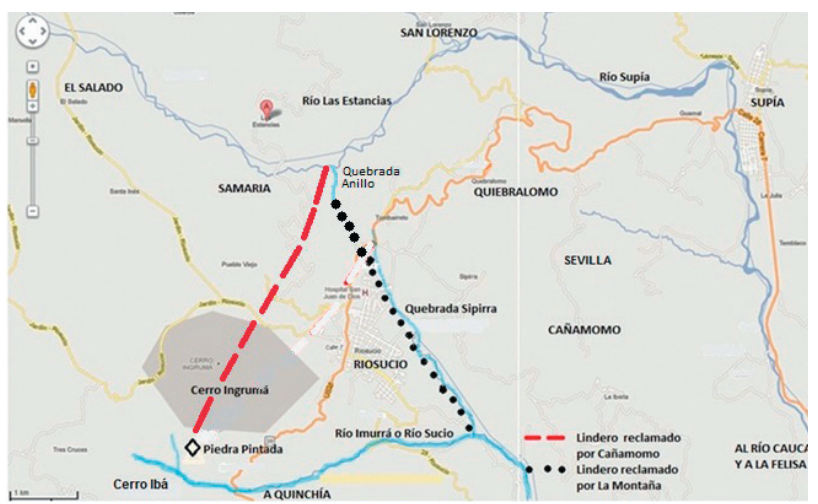

Mapa de la disputa por el sitio de Riosucio. La línea roja significa el lindero reclamado por Cañamomo Lomaprieta en 1721, que subía hasta la Piedra Pintada. Los puntos negros señalan el lindero reconocido por el Virrey José Alfonso Pizarro a La Montaña en 1751 
Como se dejó dicho atrás, el nombre de río Sucio lo puso en 1538 el conquistador Juan Vadillo al río que los nativos llamaban "Imurrá". De ahí dicho nombre recorrió dos kilómetros al norte hasta el pie del cerro Ingrumá, sitio que ya a comienzos del siglo XVIII se conoce con el nombre de "Riosucio".

Para 1721 el sitio de Riosucio estaba ocupado por rozas y labranzas de los indios Cañamomos, aunque su pueblo estaba en el partido de Lomaprieta, mientras los indígenas de La Montaña tenían su pueblo cerca del río Santa Inés (hoy Montaña Vieja o Samaria). Aquel año los indígenas de La Montaña, liderados por el cacique Andrés Motato (posiblemente secundado por el cura doctrinero), decidieron pasarse para el sitio de Riosucio, construyendo allí tres ranchos. Las autoridades de Cañamomo se opusieron porque decían tener la posesión de dicho sitio desde hacía 70 años. Los alcaldes de ambos pueblos viajaron a Santafé de Bogotá, donde el 17 de julio de 1721 el virrey Jorge Villalonga decidió el pleito a favor de los indios de Cañamomo.

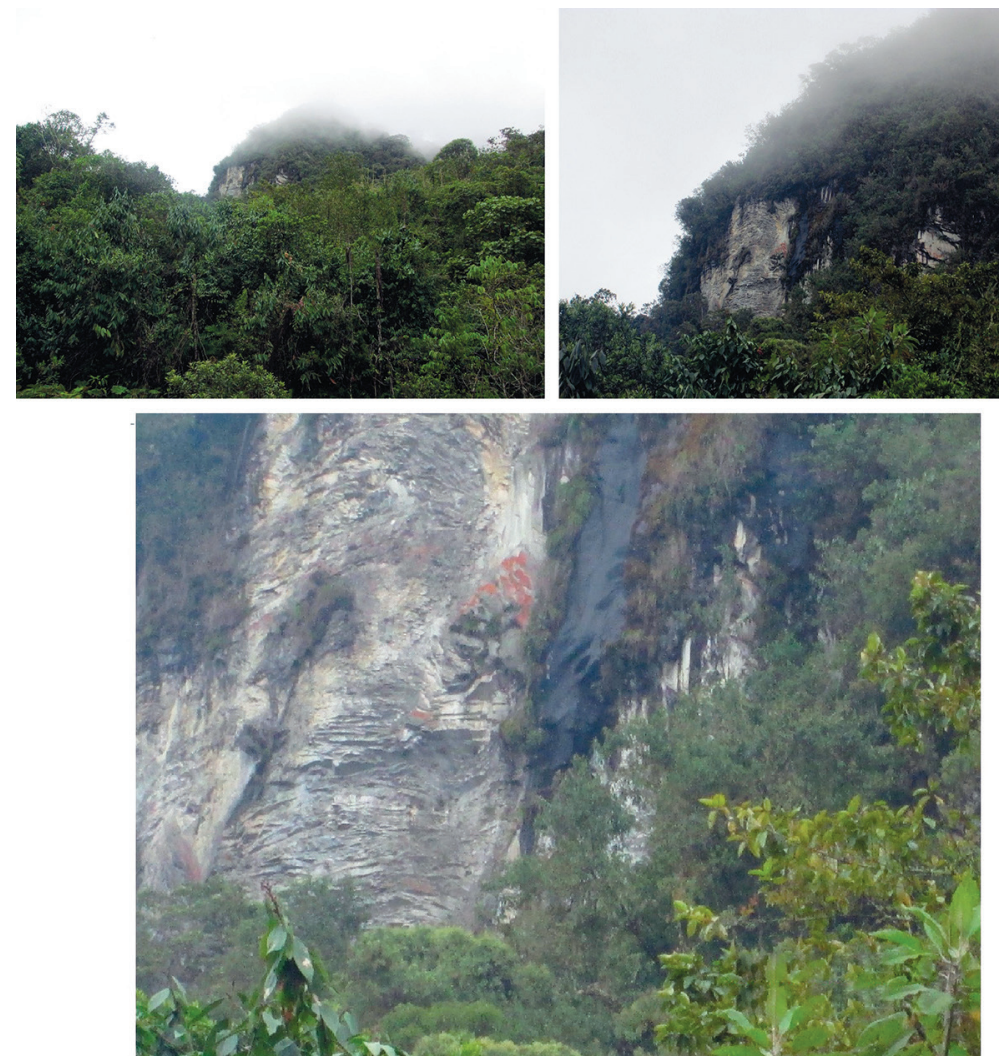

La Piedra Pintada, en los nacimientos del río Riosucio

En Santafé, el citado protector, Antonio de la Lana, hizo las siguientes peticiones:

en su vista [de las pruebas] y de los demás instrumentos demandar se libre despacho cometido al capitán Diego Martín de Guevara, alcalde mayor 
provincia del Anserma, o a la persona que vuestra excelencia fuese servido nombrar para que ampare a los indios de Lomaprieta en la antigua posesión de su resguardo, que siempre ha corrido por una quebrada que llaman "Anillo" hasta dar con la Piedra Pintada, con cuyo lindero confinan los términos del pueblo de la Montaña el partido de Lomaprieta, y que los de la Montaña no los inquieten ni se introduzcan en dichos resguardos, y se contengan dentro de los suyos sin perjuicio de los de Lomaprieta, para cuyo efecto se les quemen y derriben los dos o tres ranchos que han fabricado en dicho sitio de Riosucio, y funden el pueblo en la parte que les parece más cómoda dentro de sus linderos o lo retrotraigan al paraje donde se fundó dentro de su principio.

El 17 de julio de 1721 el virrey Jorge Villalonga le dio la razón al protector, ordenando amparar a los indios de Cañamomo en la posesión sobre el sitio de Riosucio:

Respecto de que la licencia concedida para la mutación de pueblos debe entenderse sin perjuicio de terceros, líbrese despacho más inmediatos con vista de los instrumentos de estas partes y sumario conocimiento de su derecho los ampara en la posesión de sus resguardos de que hubiese habido despojo, y que si los contrarios tuvieren que pedir lo hagan en forma en este superior Gobierno (...) En la ciudad de Santa Fe, a diez y siete de julio de mil setecientos y veintiún años.- Jorge de Villalonga.- Por mandato de su excelencia, don Martín Carlos Sáenz de Pontón, para que las justicias más inmediatas al partido de Lomaprieta ejecuten lo que aquí se les ordena a pedimento del protector nombrado de los naturales de este reino por los indios de Lomaprieta ${ }^{37}$.

El 4 de noviembre de 1722 el alcalde de la ciudad de Anserma, Juan Jiménez Gamonares, les hizo entrega material de los terrenos de Riosucio a los alcaldes de Cañamomo, Julián Blandón y Manuel y José Cumba, en la forma acostumbrada en el derecho Español para trasmitir la propiedad, consistente en tomar de la mano el juez a los dueños del predio y pasear con ellos recogiendo yerbas y tirando piedras en señal de posesión real de dueños:

En el sitio de Riosucio, jurisdicción de la ciudad de Anserma de la Gobernación de Popayán, en cuatro del mes de noviembre de mil setecientos y veinte dos años, parecieron ante mí el sargento mayor Juan Jiménez Gamonares, alcalde ordinario de la ciudad de Anserma, por el Reino de su señor, Manuel Cumba y Julián Blandón y Joseph Cumba, habiéndome requerido por un despacho de su excelencia el señor Virrey, en el que manda dé posesión a los dichos indios del partido de Loma prieta. Y de los resguardos que comprenden desde la quebrada que llaman Anillo hasta la piedra pintada, cogiendo desde dicha piedra pintada la quebrada abajo vertiente al río Sucio, y río Sucio abajo hasta el desemboque del río Supía, de aquí río arriba hasta la quebrada Anillo, les 
doy la posesión a dichos indios del partido de Loma prieta, sin perjuicio del patronato real ni de tercero que mejor derecho tenga a ellas, y se las doy judicial. Y estando en dichas tierras cogí de la mano a Manuel Cumba y a Julián Blandón, y las pasearon conmigo y después arrancaron unas yerbas en señal de posesión, las cuales les di, y apreciaron actual Corporal Velquase sin contradicción ninguna, y en ella interpuso mi autoridad y decreto judicial, y en cuanto puedo según derecho los amparo en dicha posesión. Y para que conste lo firmo con testigos que se hallaron presentes a falta de escribano público ni real.- Juan Jiménez Gamonares.- Nicolás Díaz.- Joseph de la Serna ${ }^{38}$.

De esta manera el sitio de Riosucio, quedó para los indios de Cañamomo Lomaprieta. Pero no por mucho tiempo.

\section{En 1751 el pueblo de La Montaña recupera el sitio de Riosucio.}

El cacique Andrés Motato y demás mandones de La Montaña no se resignaron a perder el sitio de Riosucio, pues según ellos el visitador Lesmes de Espinosa se lo había entregado a su pueblo y no al de Lomaprieta, por lo que continuaron el pleito. En 1745 el caso estaba en manos de Simón Pablo Moreno de la Cruz, teniente gobernador de las Cuatro Ciudades de Toro, Cartago, Anserma y Arma y corregidor de los naturales de ellas, quien encontró la relación de la visita de Lesmes de Espinosa, la cual se hallaba perdida por maquinaciones dolosas de algunos españoles y de los curas de la Vega, y con base en estos instrumentos le dio la posesión del sitio litigado al pueblo de La Montaña en el año 1748. Los Cañamomos reclamaron, pero solo consiguieron que en 1750 el virrey José Alfonso Pizarro confirmara la posesión dada por el teniente a los Montañas y que al año siguiente el mismo Moreno de la Cruz fijara con precisión los linderos entre los dos resguardos por el zanjón de Gasparillo y la quebrada Sipirra:

En el sitio de la Vega jurisdiccion de la ciudad de Anserma en catorce de agosto mil setecientos cincuenta y un años Don Simon Pablo Moreno de la Cruz Teniente Gobernador Justicia Mayor Corregidor de naturales y Alcalde mayor de minas de las Cuatro Ciudades, de Anserma, Cartago, Toro y Arma, digo que vistas las informaciones antecedentes y en virtud de lo mandado por su excelencia en que ampara a los Indios del pueblo de la montaña asi al Paraje del Rio Sucio en las tierras según los linderos que les señale en la posesion y tambien el año de cuarenta y ocho en virtud de Real Provision por los mismos linderos que los habia dado Don Antonio Bartolome de Rio y Malo cuando fue teniente cuyos instrumentos originales los remiti a la ciudad de Anserma y los citados linderos son del Rio de Supía por el canalón de Gasparillo, a dar a la ciénaga de Tumba Barreta, corriendo por el filo de la cuchilla de Terraplén que

38 Ídem. La figura jurídica se conoce como "posesion real, corporal vel cuasi". Una tradición riosuceña se refiere a este suceso y dice que las yerbas se recogieron en el sitio donde hoy está el Centro de la Música y las Artes. 
era el camino real antiguo a dar en la quebrada de Sipirra, quebrada abajo hasta donde se encuentra con Rio Sucio, a donde declaran los testigos esta la Piedra [Pintada] y expresan en la informacion dentro de los cuales linderos como lo manda su excelencia ampara manteniendo en la posesion que desde el año de cuarenta y ocho cuyos linderos son los expresados a los indios de la Montaña el cual pedazo de tierras es el que han litigado no obstante de no haberse verificado cual sea la Piedra Pintada por ninguno de las partes y en el interes que no se justifica plenamente persona alguna inquiete a dichos indios ni los perturbe en manera alguna pena del interes de las partes y de veinte y cinco pesos de buen oro aplicado para la camara de su Majestad y mediante amparar su excelencia a los indios de Cañamomo o Lomaprieta en las tierras que les señalo el Señor Doctor Don Lesmes de Espinoza y Sarabia oidor que fue de la Real Audiencia de Santa Fe visitador General de estos partidos a los Indios de Supía Pirsas y Sonsones del pueblo de Supía de los que dicen ser descendientes dichos Cañamomos a los que se amparan en dichas tierras de Supía que los hara saber para si quisieren darles posesion la que podrian pedir ante mi o otro juez que se les dara según la asignacion de los instrumentos insertos en dicho despacho asi lo probeo mando y firmo yo Teniente con testigos actuando por falta de escribano=Simon Pablo Moreno de la Cruz=Salvador Ignacio de Rio y Malo $=$ Pedro Garcia del Oyo $={ }^{39}$.

Los indígenas de Cañamomo terminaron por aceptar la pérdida del sitio de Riosucio, aunque se demoraron dos siglos en consignar dicha pérdida en sus títulos. En 1936, siendo gobernador de la parcialidad Israel Tapasco, y ante un nuevo extravío de los instrumentos originales, el Cabildo de Cañamomo tramitó una prueba supletoria del título del Resguardo, como lo permite el artículo 12 de la Ley 89 de 1890, mediante las declaraciones de cinco testigos, a saber: Jesús María Taborda, Juan Francisco Cataño, Miguel Flores, Manuel Quintero y Clímaco Lemus, todos los cuales declararon en el mismo sentido que lo hizo el primero de ellos, Jesús María Taborda:

Es muy cierto que yo oí decir a mis mayores que el resguardo y la parcialidad de indígenas de Cañamomo era por los siguientes linderos \# De la quebrada que llaman de Anillo a la piedra pintada; de allí a la quebrada vertiente al río Riosucio; Río Riosucio abajo hasta su desemboque en el río Supía; Río de Supía arriba hasta el desemboque de la quebrada de Anillo, punto de partida; pero que por una disputa con la parcialidad de la Montaña quedaron los linderos por la quebrada de Sipirra, alto de Terraplén y el zanjón de Gasparillo ${ }^{40}$.

39 "Los indios del Supía con algunos de los de Cañamomo sobre haberse introducido estos en las tierras de sus resguardos", en: Archivo General de la Nación (AGN), "Indios de Supía: pleitos por tierras de resguardo" RESANT-CAU-TOL: SC.53,1,D.25, págs. 673v, 674r, subrayas fuera del texto.

40 Escritura No.79 de 1936 de la Notaría de Riosucio. Después de la muerte del cacique Motato, ocurrida en 1742 (dato suministrado por Álvaro Gartner), el pueblo de Nuestra Señora Candelaria de la Montaña siguió con la 


\section{En 1758 se declara la unión de los pueblos de Cañamomo y Supía la Baja.}

El reconocimiento en 1751 del dominio del pueblo de La Montaña sobre el sitio de Riosucio dejó en muy mala situación territorial a los indios Cañamomos, que quedaron reducidos al mero sitio de Lomaprieta (La Iberia). Esta situación determinó que en 1757 los Cañamomos, asesorados por Simón Pablo Moreno de la Cruz (antes teniente de Gobernación de Popayán y ahora alcalde de la ciudad de Anserma), volvieran los ojos hacia las tierras que les fueron despojadas en la Vega de Supía, iniciando así un nuevo pleito, esta vez con el pueblo de Supía la Baja, que estaba en posesión de toda la Vega ${ }^{41}$.

Por este pleito se conoce que los Cañamomos eran los mismos Pirzas que habitaban en el valle del río Sucio (río Imurrá); que en la visita del oidor Lesmes de Espinosa y Saravia de 1627 fueron trasladados para la Vega de Supía, donde se les dieron suficientes tierras de resguardo; que los vecinos de la Vega ocultaron los títulos dejados por el visitador y les vendieron las tierras a los curas de Supía; que por este hecho los Pirzas tuvieron que desplazarse hacia la parte montañosa, al sitio de Lomaprieta o Cañamomo, de cual tomarían el nombre que los identificaría en adelante.

El pleito comenzó por un cobro de impuestos que el corregidor de indios de Supía, Francisco Javier de Borja, le hizo al pueblo de Cañamomo, y éstos respondieron que se cobrara con las rentas producidas por el arriendo de las tierras llanas de la Vega que usufructuaban los Supía pero que les pertenecían a los Cañamomos:

Señor Teniente de oficial real, y de corregimiento. Juan de Blandon Alcalde de los Indios de Lomaprieta por mi, y en nombre de todos los indios de mi parcialidad en el grado que aya lugar en derecho y al nuestro convenga parecemos ante vuestra merced y decimos, que nosotros teníamos nuestro Pueblo, en el Valle de Pirsa y por resguardos de tierras todo el dicho valle de donde nos sacó señor oidor Don Lesmes de Espinosa y Sarabia visitador general de esta Provincia para las fundaciones de Pueblos, y repartimientos de sus resguardos y nos fundó en las cabeceras de esta Vega, cuatro parcialidades en esta forma a los naturales de Supía la Baja de la Iglesia para arriba, a los de Supia la alta en donde se hayan hoy, y a nosotros en el Llano del Molino señalándoles a cada uno sus linderos; a los sonsones desde la quebrada de pasabanda y esta que divide la Loma de Quitambre y la de Velasques hasta las caídas de la Loma que cae a la quebrada inmediata al Pueblo de Supía la Baja,

causa en Santafé. El 14 de agosto de 1759 el virrey José de Solís Folch de Cardona expidió copia del título a su favor , el cual se limita a reproducir los linderos que aparecen en la relación de Lesmes de Espinosa y Saravia del 15 de marzo de 1627, sin mencionar la posesión dada por Moreno de la Cruz en 1751.

41 Pleito de los indios de Supía con los de Cañamomo por haberse introducido éstos en las tierras de sus resguardos (1757-1759). Archivo General de la Nación (AGN), "Indios de Supía: pleitos por tierras de resguardo," RESANT-CAU-TOL:SC.53,1,D.25, 136 págs. 
a estos desde dichas caídas hasta las estancias que tenían Cristobal Sanches en donde se alla hasta hoy un nacedero, que han conservado por lindero q esta debajo de la casa que hoy tiene Don Agustin de Castro, en derechura a las tierras altas que van para el Marmato, a los Supías la Alta la Bega arriba hasta las sierras altas que hasta hoy poseen, $y$ a nosotros toda la tierra llana, y faldas de debajo de las dos estancias de Cristobal Sanchez Ellin las cuales tierras eran

$590 v$

de Doña. Elvira Ramirez a quien las quito para nosotros, y a dicha Señora le remuneró en las tierras que dejamos nosotros en el Valle de Pirsa en cuya posesion nos mantuvimos hasta que ocultándonos nuestros títulos nos las quitaron injustamente y se las dieron a las Iglesias, y en el tiempo que estas las poseyeron según hemos oído decir de arrendamiento del Llano para la seba de los ganados produjeron más de diez y ocho mil pesos de oro de los cuales solo se han aprovechado las tierras que hay circumvecinas que se han comprado con dichos arrendamientos lo que plenamente justificaron los naturales del Pueblo de Supia el año de cincuenta y por habérsenos quitado dichas nuestras tierras nos retiramos a un sitio que llama Cañamomo en donde nos hemos mantenido con grandes necesidades, y este sitio linda hoy en dia con parte de las tierras que se han comprado con los usufructos de nuestro Llano el que a pedimento de los Naturales del Pueblo de Supia en vista de las Ordenanzas de dicho Sr. Oidor Visitador en donde constan todo lo que llevo relacionado el año de cincuenta que pudieron hallar los instrumentos el excelentísimo Sr. Virrey de este reino declaro ser nuestro dicho Llano, y en virtud de despacho de Su excelencia Don. Francisco Antonio Lopes de Vicuña siendo Alcalde ordinario nos dio posesion y después en otro despacho manda su excelencia que se nos ampare en dicha asignación, y siendo Don Simon Pablo Moreno siendo Teniente y nuestro corregidor lo que producía dicho nuestro Llano de arrendamientos de las entradas de ganados, y que se perdían informo al excelentísimo señor Virrey, y su excelencia fue servido de mandar se funde caja de comunidad cuya orden vino cuando ya dicho Don Simon había cesado en su empleo, y hasta lo presente no se ha dado su cumplimiento en grabe perjuicio de toda la comunidad, y de su majestad a quien le somos deudores de muchos pesos de resagos de nuestras tasas que no hemos

$591 \mathrm{r}$

podido pagar por nuestra pobreza, y porque aviendo caja de comunidad de ella debe salir se ha de servir vuestra merced de sacar de dicho dinero lo que estubieramos debiendo de resagos por las cuentas que hubiere dado dicho Don Simón, y los recibos que tubieremos, que pagamos con dicho dinero, que contemplamos sea cantidad crecida asi por las entradas de ganados que ha habido como por estar mandado por los SS. De la Real Audiencia de Santa Fe 
desde en tiempo que fue Teniente don Jose de Abila paguen arrendamientos todos los que ocuparen nuestras tierras según la costumbre, y en todo el mundo se paga el que vive en ajenas tierras, y aquí no hay otras que las relacionadas de los resguardos $(\ldots)^{42}$.

Borja se opuso a esta solicitud y entabló el pleito ante la Real Audiencia, donde en un primer momento el fiscal protector de los Supías solicitó "el exterminio de la parcialidad de los Cañamomos y su reduccion a uno de los pueblos mas inmediatos al sitio donde hoy habitan" ${ }^{43}$; pero muchos testimonios, en especial el de Simón Moreno de la Cruz, alcalde Anserma, y el de Diego Joseph de Ayala, cura de Quiebralomo, fueron determinantes para que el fiscal desistiera de su determinación, y propusiera, en cambio, que los dos pueblos compartieran el Resguardo en calidad de "juntos pero no revueltos". Para ello el fiscal reunió en Santafé, en febrero de 1758, a Miguel Batero y Juan Blandón, indios principales de Supía y Cañamomo, y redactaron un convenio de unión. Para asegurar el cumplimiento de éste, se le prolongó el mandato por seis años a cada uno y se ordenó recompensarlos por los gastos en que incurrieron en defensa de sus comunidades. Este convenio fue aprobado por el virrey José Solís Folch de Cardona el 3 de marzo de 1758, cuando dispuso:

Vistos con lo expuesto por el Señor Fiscal Protector y que la transaccion y convenio a que ha reducido a los indios de Supia y Cañamomo es muy favorable a unos y a otros con lo que se evitan continuados recursos a este Superior Gobierno, y se consigue vivan en quietud, se aprueban las capitulaciones que se contienen en el escrito de dicho Fiscal Protector y para su cumplimiento, con su inserción, se libre el despacho correspondiente al Teniente Oficial Real o a cualquiera Juez que se halle en el sitio de Supía y el dicho Teniente o cobrador de Reales derechos hara satisfagan los Cañamomos los tributos que buenamente debieren caidos sino solo los que pudieren satisfacer en toda equidad y asegurar los venideros respecto de concederseles tierras para labores $\mathrm{y}$ crianza de ganados $=(\text { Solís }- \text { Monroy }- \text { Dr. Rocha })^{44}$.

Esta provisión dio lugar a que los pueblos de Supía y Cañamomo formaran un solo Resguardo, que subsistiría más de cien años, pues solo vino a ser disuelto en virtud de la Ley 44 de 1973 del Estado Soberano del Cauca, en cuyo desarrollo los terrenos del Resguardo de Supía y Cañamomo fueron repartidos en tres partes: una para el Distrito de Marmato, otra para el Distrito de Supía y una tercera quedaba para los indígenas, como se verá más adelante, al tratar del gran despojo al pueblo de Cañamomo.

42 Memorial de Juan Blandón, alcalde de Lomaprieta, a Francisco Javier de Borja, corregidor de indios de la Vega de Supía y cobrador de tributos, agosto de 1957. Ídem, págs. 590-591. 


\section{Los indígenas de La Montaña compran los terrenos de Pirza en 1759}

El mismo año que el virrey Solís le renueva los títulos del resguardo a los indígenas de La Montaña, un grupo de veinticuatro comuneros de este pueblo se junta y reúne la suma de trescientos patacones para repoblar el Valle de los Pirzas, colindante con su resguardo. Estos indígenas pertenecían a diez familias, a saber: Ladino, Bañol, Guapacha, Gaspar, Motato, Tabarquino, Largo, Pescador, Morales y Durán. Para dicho repoblamiento o expansión de su resguardo, los indios de La Montaña le deben comprar los terrenos a la española Catalina Jiménez Gamonares, posiblemente hermana de Juan Jiménez Gamonares, mencionado alférez de Anserma en 1721.

El 24 de octubre de 1759 la señora Jiménez se presenta ante Manuel Lozano, alférez real de la ciudad de Anserma, para expresar que le había vendido un derecho de tierras que tenía en el sitio de Pirsa a Adrián Guapacha:

En el sitio de la Vega, jurisdicción de la ciudad de Anserma, en veinticuatro días del mes de octubre de mil setecientos cincuenta y nueve años, ante mí, don Francisco Antonio López de Vicuña, alférez real y alférez ordinario más antiguo de dicha ciudad, y testigos con quienes actúo por falta de escribano, pareció [compareció] presente doña Catalina Jiménez Gamonares, viuda, a quien certifico que conozco, y dijo que vende realmente y con efecto a Adrián Guapacha, natural del pueblo de la Montaña, un derecho de tierras que tiene en el sitio de Pirsa, en cantidad de trescientos patacones que le tiene entregados y por no parecer de presente la entrega, para que yo, dicho alférez, certifique [...] en cuyo testimonio así lo digo y otorgo, y por no saber firmar lo hizo a su ruego uno de los testigos con quienes actúo por falta de escribano-Francisco Antonio de Vicuña -- A ruego de doña Catalina Jiménez Gamonares, Francisco Javier de Borja-Testigo Manuel González - Testigo Tomás de Villanueva ${ }^{45}$.

Catalina Jiménez, por su parte, había adquirido los terrenos de uno de los curas de la zona, pues aportó al negocio una escritura de compromiso del 3 de julio de 1699 otorgada por Juan de Segueira y Serna, cura del real de minas de Quiebralomo, y Pedro León de la Peña Minaya, cura del pueblo de la Montaña, para definir el dominio de los terrenos de Pirza a ambos lados del río Riosucio sin acudir a pleito judicial.

El "Testimonio" también da cuenta de las gestiones adelantadas en 1763 por parte de Adrián Guapacha, Emeregildo Bañol, Manuel Bañol y Juan Manuel Guapacha, "indios principales del pueblo de Nuestra Señora de la Candelaria de la Montaña" ante MANUEL LOZANO, alférez real de la ciudad de Anserma, para que este funcionario les hiciera la entrega real de dichos terrenos de Pirza, e incluye la providencia de la

45 “Testimonio a favor de los terrenos de Pirsa, año de mil ochocientos sesenta y seis". Archivo General de la Nación. CO.AGN.SR.60a.30.12.1.1 / [Resguardo Indígena de Pirsa y Bonafont (Caldas): Existencia] (1939/1939). Folios; 1-26. Las citas que siguen son tomadas del mismo documento. 
respectiva entrega, la cual tuvo un costo de seis patacones. El 29 de agosto de 1763 tuvo lugar la diligencia de entrega, en presencia de las autoridades del pueblo de Quinchía y de algunos españoles, vecinos de los terrenos de Pirza:

En el sitio de Pirsa de la Vega de Supía, jurisdicción de la ciudad de Anserma del gobierno de Popayán, en veintinueve días del mes de agosto del año de mil setecientos sesenta y tres, don Manuel Lozano, alférez ordinario más antiguo de dicha ciudad y jurisdicción por su Majestad, en conformidad de lo mandado en el decreto de veintidós (22) del presente mes y año, estando presentes Manuela Pérez y sus hijos, y Agustín del Pozo, dueños de dichas tierras, José Rufiano y Luis Aricapa, alférez y regidor del pueblo de Quinchía, respectivamente, al sitio de Pirsa con los instrumentos que me manifestaron y tuve presentes con todo acuerdo y vistos y que constaron en el compromiso que hicieron don Juan de Segueira y Serna, cura del real de Quiebralomo, y el doctor don Pedro León de la Peña Minaia, a los dos días del mes de julio de mil seiscientos noventa y nueve años, ante don Francisco de Borja y Espeleta, siendo alférez ordinario, según consta de él, tocándole al señor don Juan de Segueira desde la quebrada que llaman del Guadual hacia Juandíaz, corriendo para arriba a la quebrada primera de mano derecha, y en ancho hasta el sitio que llaman de Las Cuevas, lindando con las que poseen los naturales del pueblo de Quinchía, en cuya conformidad, y dándoles a los presentantes las que les pertenecen, cogí de la mano puesto en dicha quebradilla que ahora llaman Ochala, desaguando dicha quebrada de Juandíaz, a Manuel Bañol, Ermeregildo Bañol, Adrián Guapacha, y en nombre de Bernardo Bañol y Juan Manuel Guapacha, les di posesión a los cinco dichos como propios dueños de ellas, en cuya señal pasearon, arrancaron yerbas y movieron piedras de un lado a otro, e hicieron otros apuntes en señal de verdadera y legítima posesión, en cuya consecuencia se las di corporal actual del casi [posesión real, actual , corporal vel cuasi] sin perjuicio del patrimonio real ni de otro tercero que mejor derecho tenga, por lo cual ordeno y mando a todos y cualquiera persona del estado, condición o calidad que sean no inquieten a los dichos naturales en su posesión hasta no ser oídos y vencidos, lo que cumplirán puntualmente, so pena de cien pesos de buen oro, aplicados en la forma ordinaria; y es de advertir que desde la dicha quebrada de Ochala desde su cumbre hasta donde desagua a Juandíaz abajo le quedan por linderos pertenecen, por todo lo que y para que conste lo firmo con testigos por falta de escribano. Manuel Lozano. Testigo, José Fernando Montaño Ortiz. Testigo, Pedro Antonio García.

En dicho día, mes y año hice saber esta posesión a Manuel Bañol, Juan Bautista Motato y a Bernardo Bañol, y a éstos en nombre de Emeregildo Bañol y Adrián Guapacha, quienes lo firmaron conmigo y testigos por falta de escribano. Lozano. Manuel Bañol, Juan Bautista Motato, Bernardo Bañol. Testigo, José Fernando Montaño Ortiz. Testigo, Pedro Antonio García. 
"Y luego yo, dicho alférez ordinario, les hice saber la posesión por mí dada a Manuela Pérez y sus hijos y [a] Agustín del Pozo, como a los naturales de Quinchía en sus personas que lo oyeron y entendieron, y para que conste, lo firmo con testigos por falta de escribano. Lozano. Testigo, José Fernando Montaño Ortiz. Testigo, Pedro Antonio García"

Al final del "Testimonio" aparecen unas disposiciones que tomó el pequeño Cabildo de La Montaña para el reparto de esas tierras entre los descendientes de los indígenas que hicieron la compra en 1759.

\section{Los quiebralomeños se introducen al sitio de Riosucio.}

Volviendo al sitio de Riosucio, pese a que el pueblo de La Montaña ganó el dominio sobre el sitio de Riosucio en 1759, frente al pueblo de Cañamomo, dicho sitio permaneció durante el resto del siglo XVIII en disputa, pero ya no con los indígenas de Cañamomo, sino con los mulatos de Quiebralomo, quienes debido a la estrechez en que estaban en el real de minas se metieron a las tierras de Riosucio y Tumbabarreto, provocando las correspondientes protestas de parte de los indígenas de la Montaña ante las autoridades del Reino, a la vez que los quiebralomeños pedían se les reconociesen su asentamiento en dichos sitios, en una situación que sólo vino a resolverse con la fundación de Riosucio en 1819.

En este interregno el sitio de Riosucio no permaneció desocupado. Se alcanzan a construir casas y aún una iglesia en el sitio de Riosucio, en un poblamiento de alguna permanencia, que hace decir a Álvaro Gartner que Riosucio no se fundó en 1819 sino que es un pueblo del siglo XVIII:

Se creía que antes de esa fecha, el terreno que hoy ocupa Riosucio estuvo desocupado e ignorado. Es fácil imaginarse que mientras las tropas libertadoras derrotaban a los españoles en el río Teatinos en Boyacá, una fila de indios cargados con su bártulos asomaba por el Alto del Chocho, al pie del cerro Ingrumá. Y al mismo tiempo, un pueblo de mulatos se desperdigaba por las mangas de Tumbabarreto para construir entre todos un nuevo pueblo.

La historia tiene una versión distinta. Entre otras, que el 7 de agosto de 1819 no fue el comienzo de una fundación, sino el final de un período de 107 años, muy conflictivo. El proceso de fundación de Riosucio es producto de los litigios por la propiedad de su terreno sostenidos durante el siglo XVIII entre los indios de la Montaña y de Cañamomo y los mulatos de Quiebralomo. A la sombra de esa pelea fue surgiendo un pueblo al que sólo se aceptó como tal en el siglo XIX, pero que tenía vida desde casi cien años atrás ${ }^{46}$.

46 Álvaro Gartner Posada. "Fundación de Riosucio. Un pueblo del siglo XVIII". Cali, agosto de 1999, mimeo, incluido en el CD "Cátedra Riosuceña" 
En 1768 los mineros quiebralomeños acudieron al virrey Pedro Messía de la Cerda para solicitar que les cedieran a ellos los terrenos del sitio de Riosucio y además los que iban hasta Quiebralomo, desconociendo que ya desde 1751 se había tomado decisión sobre el lindero entre La Montaña y Cañamomo. Gartner informa que los mineros incluso pagaron de su bolsillo una comisión que dictaminara sobre el asunto. Este despojo fue impedido por la oportuna llegada a Santafé de Bogotá de una delegación de los indios de Cañamomo, quienes buscaron la protección de Francisco Antonio Moreno y Escandón, el fiscal que con anterioridad los había representado en el pleito con el pueblo de La Montaña.

En un enérgico memorial del 18 de enero de 1769, el fiscal Moreno y Escandón alegó que por pleitos anteriores (el de 1750-1751), en que habían participado dos fiscales, uno por La Montaña y él por Cañamomo, ya era cosa juzgada que el sitio de Riosucio pertenecía al pueblo de La Montaña, por lo que "no se alcanza el motivo de que los mulatos agregados a Quiebralomo pretendan despojarlos con el especiero nombre de mineros", por lo que desposeer a los Montañas "sería alterar todas las reglas del derecho". Finalmente, el fiscal propuso que la solución solo "es exequible en una visita" al terreno por parte de la Audiencia.

Dada la determinante influencia del Fiscal sobre el virrey, éste decidió abstenerse de tomar una decisión de fondo en el caso, y en su lugar el 17 de febrero de 1769 dictó una medida provisional, por la cual estableció un "statu quo" (que queden las cosas como están), para que los indios de La Montaña y los mulatos de Quiebralomo compartieran mancomunadamente el sitio de Riosucio, mientras viajaba a la zona "algún señor Ministro, con cuya presencia y reconocimiento pueda darse la última mano en este enredado negocio" 47 .

Álvaro Gartner muestra, en el artículo citado, cómo hasta el final del siglo se suceden los memoriales, unas veces solicitando el traslado de La Montaña para el sitio de Riosucio; otras veces el traslado de Quiebralomo para el mismo sitio; otras más los propios quiebralomeños oponiéndose al traslado; peticiones que en ocasiones respondían a intrigas de los curas, de las autoridades o de las compañías mineras que empezaban a llegar a la región luego de una prolongada crisis en este ramo económico.

47 Tanto el alegato del Fiscal Moreno como el Decreto de estatu quo constan en copia expedida por Ambrosio Peña J., Archivero Nacional, el 16 de septiembre de 1907, "tomada del Protocolo - Tomo Seis - 'Tierras del Cauca' que reposa en el Salón Colonial”. Localización: Archivo del Cabildo Indígena Cañamomo Lomaprieta. 


\section{Cómo era el territorio de Riosucio en $\mathbf{1 7 7 1}$}

Pero ¿cuál era el escenario en el cual desenvolvía esta disputa? Para saberlo se cuenta con la detallada relación que hicieran de la provincia de Anserma en el año 1771 los dos alcaldes de ella (Juan José Gutiérrez del Toral y Diego Joseph Leonín de Estrada) por orden del virrey Pedro Messía de la Cerda, y cuyo estado se sintetiza así:

Cuadro de población de la Ciudad-Provincia de Anserma 1771

\begin{tabular}{|c|c|c|c|c|}
\hline Centros poblados & Habitantes & Cantidad & Total & $\%$ aprox. \\
\hline Anserma la Nueva & $\begin{array}{l}8 \text { eclesiásticos } \\
230 \text { españoles } \\
40 \text { esclavos de la iglesia } \\
230 \text { esclavos de los españoles } \\
280 \text { mestizos } \\
220 \text { pardos y negros libertos } \\
60 \text { indios }\end{array}$ & 1.068 & 1.068 & $30 \%$ \\
\hline Anserma Viejo & $\begin{array}{l}170 \text { personas ( } 3 \text { blancos, } 11 \\
\text { esclavos, y el resto mestizos y } \\
\text { mulatos o pardos). }\end{array}$ & 170 & \multirow[t]{4}{*}{2.464} & \multirow[t]{4}{*}{$70 \%$} \\
\hline Pueblos de indios: & $\begin{array}{l}\text { Tachiguía: } 69 \text { indios } \\
\text { Guática: } 269 \text { indios } \\
\text { Quinchía: } 128 \text { indios } \\
\text { Supía (incluye Marmato): } \\
188 \text { indios } \\
\text { Cañamomo: } 91 \text { indios } \\
\text { La Montaña: } 353 \text { indios } \\
\text { San Lorenzo: } 114 \text { indios }\end{array}$ & 1.212 & & \\
\hline $\begin{array}{l}\text { Real de Minas de } \\
\text { Quiebralomo }\end{array}$ & $\begin{array}{l}1 \text { eclesiástico } \\
701 \text { pardos (mulatos) } \\
10 \text { blancos } \\
55 \text { mestizos } \\
11 \text { negros esclavos } \\
2 \text { indios (no se cuentan aquí) } \\
16 \text { domésticos } \\
12 \text { zambos } \\
14 \text { sin raza definida }\end{array}$ & 822 & & \\
\hline Población negra: & $\begin{array}{l}\text { Marmato: } 100 \\
\text { Guamal: } 130 \\
\text { Anserma Viejo: } 30\end{array}$ & 260 & & \\
\hline Total & & & 3.532 & $100 \%$ \\
\hline
\end{tabular}

Fuente: "Informe general de los pueblos del Cauca", en: Cespedesia, revista de la Universidad del Valle, Nos. 45 y 46, suplemento $N^{\circ}$ 4, enero-junio 1983, págs. 409423. Para este informe el detallado censo de Quiebralomo, San Lorenzo y Cañamomo lo hizo Diego Joseph de Ayala, cura del real. 
$\mathrm{Al}$ interior de este escenario, vale la pena detenerse a leer la descripción que hizo en su informe el alcalde Leonín de Estrada del actual territorio riosuceño, fechada el 14 de mayo de 1771, que comprende, en su orden, los pueblos de Quiebralomo, Cañamomo, La Montaña y San Lorenzo:

Yo, don Diego Joseph Leonín de Estrada, alcalde ordinario de la ciudad de Anserma, en virtud de lo preceptuado en la superior orden, paso a hacer denominación (según mi capacidad) pudiere pintar lo que se me ha hecho cargo por el señor alcalde, mi compañero, desde el río nombrado Sopinga [hoy río Risaralda] al paso de Cauca, nombrado Caramanta, cuyas aguas dividen esta jurisdicción ${ }^{48}$, la que se compone desde el citado río de Sopinga a este sitio de La Vega de seis pueblos de indios, un real de minas, nombrado Quiebralomo, una agregación de indios a él anexos, llamado 'Cañamomo'; otro real de minas, nombrado Marmato, una agregación llamada Sevilla y otra nombrada Anserma la Vieja, la que se halla en la cima de un cerro, en el que estaba fundada la antigua ciudad, la que se halla contiguo al pueblo de Chaim [Chamí] (...).

Y de la agregación citada, Sevilla, sigue un cerro que tendrá por elevación hasta su cumbre poco más de una legua, todo él compuesto de algunas cañadas muy profundas e inútiles por ser chaparrales, en cuyos ámbitos ni se puede criar ni sembrar por lo pendiente y estéril, en el que, a la similitud de un atril, se halla fundado el real de minas nombrado San Sebastián de Quiebralomo; sus casas, aunque en aquella cima, de paja, muy ordenadas; su iglesia la más decente que hay en todo este territorio; el cura de dicho pueblo es el doctor don Diego Joseph de Ayala, quien con su celo de buen pastor y el fervor y devoción de aquellos pardos, tiene la iglesia con la decencia que se manifiesta el día de hoy, siguiendo lo mismo con el culto divino, lo que no se experimenta en otros lugares de gente blanca y de comodidades, pues siendo el número tan copioso de vecinos tan sumamente pobres y la estrechez en que se hallan por no tener en donde sembrar y criar, pues a citado cerro en donde están plantados, además de lo dicho, se compone de minerales de vetas antiguos y presentes, por lo que tienen a un día de camino que transitar con sus familias para conseguir algún fruto, como es el de maíz para poderse mantener, siguiendo la misma pariedad con las maderas y pajas, por no tenerlas en el alto cerro en que se hallan fundados, en cuya cima se halla un pedazo muy corto de llano nombrado Tumbabarreto, en el que caben muy cortas reses de cría o bestias caballares. El número de dichos vecinos se demuestra por el padrón adjunto; su natural muy humilde y obedientes a la real justicia, en que se muestran leales vasallos de su Majestad; su ejercicio y modo de mantenerse es por lo común trabajar en sus minitas; sus huertas que consiguen de legumbres, 
plátanos y caña dulce son muy cortas por no darles más lugar el ámbito de la tierra, que a no derrotarse a un día de camino a distinto territorio a sembrar el pan común, como es el maíz, murieran de hambre.

Y mirando al oriente desde dicho real está una cañada muy corta, a mano derecha, llamada Cañamomo, en la que tienen su población los indios llamados cañamomos, su cura es el del citado real, a cuya iglesia concurren a cumplir con los preceptos de nuestra santa madre iglesia y educación de la doctrina cristiana, así por la inmediación como por no poder éstos fundar iglesia, así por lo pobre de ellos como por lo oprimido en que se hallan; su natural es jovial, muy pobres, pues no tienen más ministerio para pagar el tributo y alimentar la vida, que son las cortas rozas de maíz que hacen, sus platanares y algunas matas de caña dulce, constando el número de dichos indios de dieciséis tributarios, cuatro reservados y de sesenta y nueve indias, chinas y chinos.

Y siguiendo para el poniente se encuentra el citado llano nombrado Tumba Barreto, el que confina con las tierras de los indios del pueblo de la Montaña, las que son inmensas e incapaces de poderle dar regulación en su latitud y longitud, mediante a que por el poniente confinan a modo de respaldo con las cabeceras de la provincia del Chocó, de cuyas serranías salen dos ríos nombrados San Juan; el uno sigue su curso por la orilla de un pueblo adelante de Chamí de este nombre y desagua al Tadó y de ahí a la mar; y el otro del mismo nombre corre por el costado izquierdo mirando al norte a encontrarse con el río nombrado de Cauca, y por el lado derecho confina en dichos resguardos con los indios del pueblo de Guática, quedando las citadas tierras de los expresados indios a la similitud de una caja, las que son muy abundantes de aguas por tener varias quebradas y riachuelos, muy abundantes de frutos, ojos de agua sal, y para mayores y menores; su temperamento muy ameno y saludable para conservar la vida, mayormente a los naturales, como se experimenta en éstos que es el pueblo más populento de todos los que comprende esta jurisdicción, y así todo este gobierno, pues consta su número de sesenta y nueve tributarios o reservados y reservados por enfermos quince, $\mathrm{y}$ de doscientas treinta y nueve personas que, entre indias, chinos y chinas, los que sin incluir los domésticos y familiares del cura que pasarán de treinta, los que están fundados en una cuchilla, por cuyo pie corre un río nombrado Santa Inés [hoy Las Estancias]; a poco trecho se halla el citado pueblo, sus casas de paja muy ordenadas, las que se componen de una calle en largo y en los dos extremos se halla en el uno una iglesia de bahareque y su cubierta de paja, con la moderada decencia para el culto divino y Señor Sacramentado, el que tienen colocado; y en el otro una capilla del mismo material muy corta; los naturales de dicho pueblo son devotos al culto divino, de no mala índole; su ejercicio es frecuentar los más de ellos la provincia del Chocó con algunas 
legumbres que producen sus tierras, para con el fruto de ellas (o con lo que les pagan algunos que les hablan para cargar [personas] a dichas provincias o a la ciudad de Mariquita) satisfacen sus tributos, además de tener el ejercicio en sus sementeras de maíces, platanares y cañaduzales, para sus chichas y guarapos por ser bastantemente inclinados a la embriaguez; siendo por el contrario los indios más acomodados, pues pocos de ellos dejan de tener sus reses de cría. Su cura es el doctor Bernardo Cataño, el que por tener sobre noventa años y no poderles administrar el pasto espiritual, su Señoría Ilustrísima ha puesto de cura ecónomo de dicho pueblo al doctor don Francisco de Rentería.

Y siguiendo de dicho pueblo, mirando al norte a mano izquierda, sigue un cerro en cuya falda se encuentra el citado río de Santa Inés y otro riachuelo pequeño [hoy Aguas Claras] por cuya conjunta le dan la denominación del río de Supía, el que viene siguiendo por un costado del cerro de Quiebralomo, por medio de una cañada, en la que está un muy corto llano, y en él fundado el pueblo de San Lorenzo, el que se compone de catorce tributarios, cinco reservados y setenta indias, chinos y chinas; éstos son muy pobres, su iglesia muy limitada con la decencia que les permite sus fuerzas; el cura de dichos indios es el doctor don Diego Josef de Ayala, cura del real de Quiebralomo, al que está muy inmediato del citado pueblo, no habiendo más intermedio que una bajada de a un cerro, que constará de seis a ocho cuadras, en el que está fundado el real de Quiebralomo; el ejercicio de dichos indios y modo de vida en sus sementeras de maíces en los cortos montes que tienen en aquel pavimento, por ser los lados del corto llano en que se hallan fundados unos riscos de montaña ásperas; no tienen más bienes que son unas cortas matas de plátanos y a su respectiva una estancia con unas matas de caña dulce, por lo que son de común muy pobres ${ }^{49}$.

Para terminar este siglo es pertinente mencionar que para finales del mismo el pueblo de Nuestra Señora Candelaria de La Montaña conservaba el cacicazgo, en cabeza de la familia Motato. El Archivo General de la Nación conserva el expediente seguido ante el virrey de Santafé de Bogotá entre los años 1796 y 1797, relativo a la solicitud que hizo don Matías Motato, indio del pueblo de La Montaña, hijo de Alejo Motato y de Martina Morales, y nieto del cacique don Andrés Motato, a quien la tradición identifica como "Chiraka Matata", para que se le reconociera el derecho al cacicazgo de su pueblo ${ }^{50}$.

49 Ídem.

50 Álvaro Gartner. "Caciques de La Montaña", ponencia presentada en el Foro"475 años del nombre de Riosucio" en 2013. El facsímil es tomado del expediente aportado por César Augusto Taborda, bajado de la página web del AGN. 


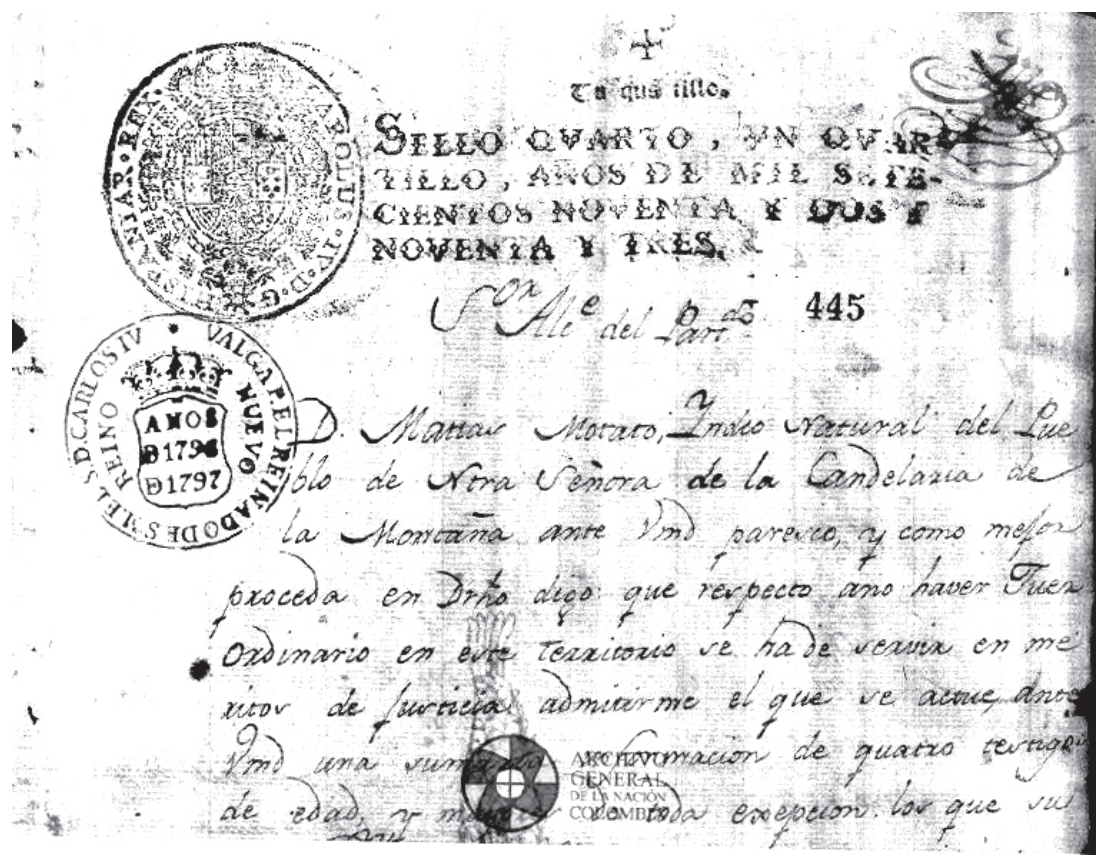

Facsímil de la primera página del expediente sobre el cacicazgo de La Montaña 

SIGLO XIX 

El último proyecto territorial de la Corona española en la Vega de Supía. Proceso de fundación de Riosucio (18141819). Riosucio visto por J. B. Bousingault en 1825-1830. El mestizaje. Los nombres que ha tenido Riosucio. Reposición del título de San Lorenzo en 1836. Erección de Riosucio en Distrito Municipal (1846), unificación de las dos parroquias y surgimiento del Carnaval. Continuidad de los resguardos indígenas en la República. El recorte del gran Resguardo de Supía y Cañamomo (1874). Registro de la Comunidad de Escopetera Pirza (1884). El área de población de Riosucio (1873-1890). La colonización antioqueña, la Oraida y el pueblo de El Rosario. La ley 89 de 1890 y las aprensiones de San Lorenzo.

Sin duda el acontecimiento que marca este siglo para la historia del territorio riosuceño es la fundación del pueblo de Riosucio entre 1814 y 1819, que conlleva a dos hechos igualmente importantes como son su erección en Municipio en 1846 y la consiguiente pérdida de importancia de La Montaña y de Quiebralomo.

1. El último proyecto territorial de la Corona española en la Vega de Supía

El siglo comenzó con un proyecto fallido de pasar los indios de la Vega de Supía para Anserma Viejo, con la excusa de los atrasos de los indios en el pago de los tributos, deuda que sería pagada con la venta de los terrenos a los mineros que empezaban a llegar a la región. El relato es de Albeiro Valencia Llano ${ }^{51}$ :

- En la agonía del régimen colonial (1805) las autoridades españolas (alcalde de Anserma Nuevo, cura de Anserma Viejo, corregidor de indios de la provincia de Anserma y alcalde de Quiebralomo) concibieron un plan para trasladar los pueblos de indios de Supía, San Lorenzo y Cañamomo para las cercanías de Anserma Viejo.

51 Albeiro Valencia Llano. Colonización: Fundaciones y conflictos agrarios (Gran Caldas y Norte del Valle), $2^{\mathrm{a}}$. ed. Manizales, 2000, págs. 340-350. 
- «En el día se venderán muy bien las tierras que aquellos poseen y de que tienen necesidad los sujetos que en esos territorios comienzan a entablar sus minerales, y con ese producto que es efectivo, cubren sino en todo, gran parte de sus rezagos» (Antonio de Velasco, cura de Anserma Viejo).

- El proceso de traslado comenzó a tramitarse, pero se opusieron los indios de Supía («Los vecinos blancos lo que quieren es aprovecharse de nuestras tierras privándonos de la legítima y antigua posesión que en ella tenemos...»), siendo apoyados por el vicario de la Vega.

- El proyecto de traslado terminó por envolatarse, pero puso de presente la estrechez en que estaban los quiebralomeños y la presión que ejercían éstos sobre los terrenos del sitio de Riosucio:

- «Quiebralomo necesita con tanta precisión como la Vega [de Supía] de población porque los muchos desórdenes que se notan dimanan de la dispersión de las casas, que las más se hallan en el monte donde no suelen salir en el espacio de años. El terreno de Río Sucio por su plan, aguas, leña y temperamento, es el único que hay donde puede poblarse pero éste hace más de 80 años (según dicen los ancianos) que lo litigan con los Montañas. En este sitio tienen los indios por sólo mantener la propiedad, una u otra casimba de cría de cerdos con lo que están echando a perder aquel terreno, consumiendo los pastos y montándolo de escoba y abrojos...» (Tomás Valencia, alcalde de Quiebralomo, 12 de abril de 1805).

El motivo de haberse envolatado el proyecto no fue tanto la oposición de los indios y sus curas sino el inicio de la Revolución de Independencia. En 1810 se dio el Grito de Independencia en Bogotá. En 1811 la provincia de Anserma hizo parte de las Ciudades Libres Confederadas del Valle del Cauca. La nueva República se enfrascó en su primera Guerra Civil, entre centralistas y federalistas (las provincias se rebelaron contra Santafé que quería conservar los privilegios de la Colonia), la cual terminó en 1814 y dejó debilitado el país para enfrentar la reconquista de 1816, comandada por el general español Pablo Morillo. 


\section{Proceso de fundación de Riosucio (1814-1819)}

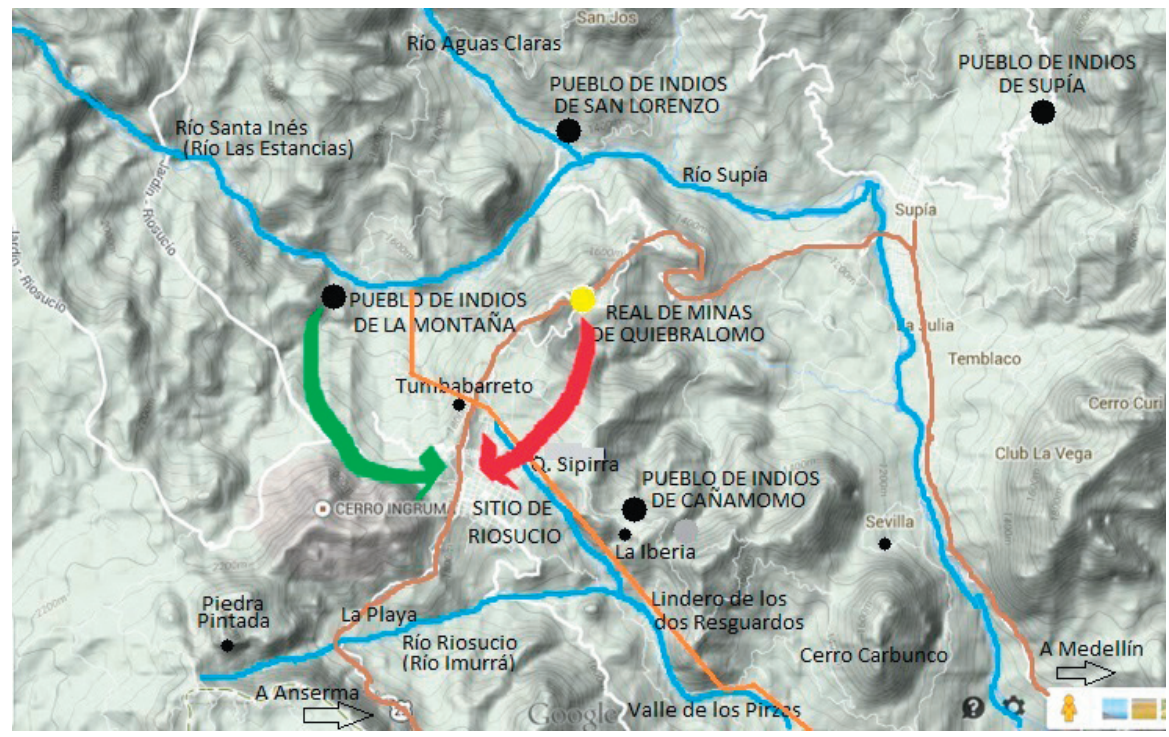

Mapa del traslado de La Montaña y Quiebralomo al sitio de Riosucio

En el paso de la Colonia a la República se dio un hecho de gran importancia local, que facilitaría llegar al fin del conflicto entre los pueblos de La Montaña y Quiebralomo, como fue la llegada a la región de los sacerdotes José Ramón Bueno y José Bonifacio Bonafont:

En enero de 1809 asumió su curato [de Quiebralomo] el sacerdote José Ramón Bueno Certucha, quien en diciembre de ese año tomó simultánea e interinamente la doctrina de La Montaña, hasta agosto de 1814. Era la primera vez en más de 200 años que las dos comunidades quedaban bajo un guía espiritual. Aunque temporal, fue un paso decisivo en la unión de las dos parroquias. En 1810 se hicieron en la Diócesis de Popayán gestiones al respecto, entre 'San José' (?) de La Montaña y Quiebralomo. Ese mismo año fue nombrado para La Montaña el sacerdote socorrano José Bonifacio Bonafont. Tal vez estaba destinado a ser el primer párroco de las comunidades unidas, porque el 4 de septiembre de 1810 otorgó en Popayán un poder general, en su calidad de 'cura del pueblo de La Montaña de Quiebralomo'. El padre Bonafont sólo asumió el 30 de agosto de $1814^{52}$.

52 Op cit., Álvaro Gartner. "Fundación de Riosucio. Un pueblo del siglo XIII”. 


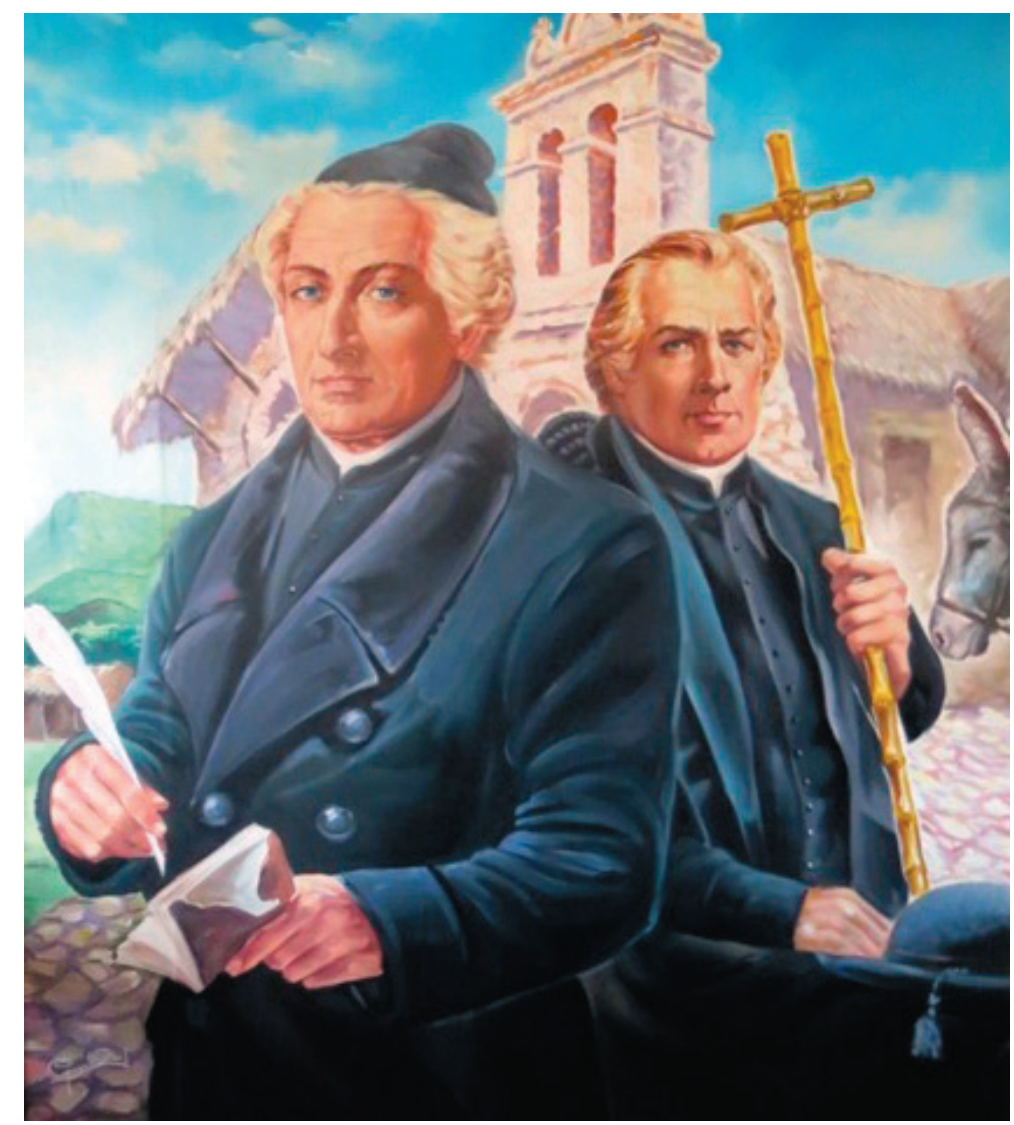

Los fundadores. Óleo de Gonzalo Díaz. Concejo Municipal.

José Ramón Bueno (n. Popayán, ? - m. Cartago, 1842)

José Bonifacio Bonafont (n. El Socorro, 1763 - m. Riosucio, 1845)

El padre Bonafont llega entonces en el periodo conocido como la "Patria Boba" a hacerse cargo de la parroquia de La Montaña, ubicada cerca al río Santa Inés (río Las Estancias, donde hoy es Samaria), encontrando el pueblo de La Montaña y su iglesia casi en ruinas, lejos del Camino Real, mientras el mejor sitio para poblar, el pequeño plan al pie del cerro Ingrumá, que pertenecía al Resguardo, estaba invadido por los habitantes de Quiebralomo, quienes, como se vio, eran muy numerosos en las lomas donde vivían y estaban estrechos de tierras para cultivos y ganados, porque los reales de minas no tenían territorio propio. La Revolución de Independencia, como toda revolución, alteró el orden de las cosas, y Bonafont, que era un activo militante patriota, aprovechó el momento para impulsar la solución del viejo pleito entre montañas y quiebralomeños, cuyo nudo gordiano eran las leyes coloniales que prohibían que en los pueblos de indios vivieran otras razas. 
En una carta del 17 de mayo de 1825 dirigida a monseñor Salvador, obispo de Popayán, el padre Bonafont relata en detalle cómo fue el proceso de fundación de Riosucio desde $1814^{53}$.

Esta carta es tan importante para la historia de Riosucio que suple la falta del acta de fundación, porque cuenta el surgimiento del pueblo como fue en la realidad (un proceso de varios años, complejo en lo político, económico, social, jurídico, eclesiástico y militar) y no el mito que a veces se narra.

El relato del padre Bonafont, escrito en medio de una disputa con el cura que asistía en Quiebralomo para 1825, Francisco de Paula Sáenz ${ }^{54}$, es el siguiente:

Segundo: afirma el señor Juez Político con imprudencia, que la Parroquia de La Montaña, está situada dentro del terreno de Quiebralomo, siendo tan constante que Quiebralomo jamás ha tenido tierras propias, pues los principios de su fundación, fueron del modo siguiente.

Cuando en estos territorios no había más curatos que el de Anserma, el de Supía y La Montaña, Quiebralomo sólo era un mineral [un real de minas], que se laboraba con cuadrillas de esclavos por varios individuos, entre éstos vino una señora de Popayán a posesionarse con sus registros, bajo los cuales se estableció en el antiguo Quiebralomo, distante de este sitio de Riosucio más de una o dos leguas así de Supía. Los esclavos de la cuadrilla de este mineral se fueron libertando y quedándose en el mismo sitio, y aumentándose aquellas gentes comenzaron a extenderse y posesionarse en las tierras de los indios de La Montaña, en cuyos límites estaban aquellas minas de Quiebralomo, y habiéndose puesto allí un cura minero se aumentó más la población con este motivo, por vecinos a extenderse más en las tierras de los de La Montaña, hasta introducirse en este sitio de Riosucio; y no pudiendo los vecinos de La Montaña sufrir más usurpación de sus tierras, representaron sus derechos ante el superior Gobierno; los de Quiebralomo fueron lanzados por dos o tres ocasiones, y posesionados los indios en sus tierras; pero aquellos fueron tan contumaces que quisieron mantener su usurpación, hasta introducirse por la fuerza armada, como es constante, y patrocinados por los curas de Quiebralomo

53 Fuente: Archivo Central del Cauca. Popayán. Signatura: 6970 (Ind. C III -2 g). Transcrita en: Álvaro Gartner Posada. Tras las huellas del padre Bonafont en el Archivo Central del Cauca. Elementos para una nueva visión de la fundación de Riosucio, ensayo leído en el Centro de la Música y las Artes en 1994, con motivo del 175 aniversario de la fundación.

54 En 1825 el padre Bonafont estaba enfrentado al padre Francisco de Paula Sáenz, cura de Quiebralomo, quien estaba apoyado por José N. Betancur y Bonilla, juez político de Supía. La discordia llegó al punto que el padre Sáenz le solicitó al obispo de Popayán que suprimiera la parroquia de La Montaña y dejara sólo la de Quiebralomo. En su reivindicación, el padre Bonafont le escribió al obispo una extensa carta en la que hace una enérgica defensa de su parroquia, relatando en detalle cómo fue el proceso de fundación de Riosucio desde 1814 y justificando porqué debían seguir existiendo las dos parroquias. 
se prolongó el pleito de su intensa posesión por más de cien años, arruinándose uno y otro vecino en costas y gastos, hasta que últimamente se determinó por la superioridad que vivieran en este sitio los vecinos de Quiebralomo que ya tenían sus posesiones, en mancomunidad con los indios, en inter se finalizaba el pleito.

En ese estado comenzó la revolución [de Independencia], y unos y otros vecinos permanecieron en paz, y el año de 14 [1814] en que entré yo a servir en propiedad este curato de La Montaña, viendo la mala situación en que se hallaba el pueblo, y que no podía progresar, le hice presente al señor Juez Mayor [de Anserma Nuevo], que lo era en aquel tiempo el señor Manuel José Lozano, quien me ofreció tratar de sacar el pueblo al lugar más cómodo, y pareciéndole este sitio de Riosucio, convocó en él a ambos vecindarios de Quiebralomo y La Montaña, y haciéndoles ver que estaban viviendo de mancomunidad y las ventajas que resultaban al pueblo de La Montaña de la traslación a este sitio, les pidió su consentimiento con respecto al terreno que ocupare la Iglesia y casas de los vecinos, quedando lo demás en terreno litigado, como estaba determinado, a lo que se negaron los vecinos de Quiebralomo, y propusieron que se reunieran las dos parroquias en este sitio; que cada vecindario reconociere su cura, y que todas las tierras quedaran comunes para los dos vecindarios, lo mismo que las minas, exceptuando las que fueran de propiedad de particulares, e igualmente los derechos de tierras que tuvieren legítimos propietarios. A esta propuesta accedieron los vecinos de La Montaña, y se celebró el convenio [el 28 de noviembre de 1814] con asistencia de los respectivos curas y jueces de ambos vecindarios y testigos fidedignos prevenidos al efecto, con los que se otorgó una escritura protocolizada, cuyo convenio aprobó el superior Gobierno Provincial a petición del muy ilustre Cabildo de la ciudad de Anserma, mandándose verificase la traslación y unión de las parroquias en este sitio dentro del término de seis meses.

En esta virtud solicité licencia del orden eclesiástico para trasladar mi iglesia parroquial a este sitio de Riosucio, y se me concedió con la facultad de visitarla y bendecirla; y habiendo construido otra iglesia el año de 15, se verificó su bendición el primero de febrero del año de 16, como consta de las diligencias, y desde este tiempo se comenzaron a construir casas conforme al reglamento dado por el superior Gobierno y cometido el señor Juez Mayor, que lo era el señor Joaquín Venancio Álvarez Ramírez, quien asistió a delinear las plaza $\mathrm{y}$ calles [sic] ${ }^{55}$. Y trasladada la parroquia de La Montaña enteramente a este sitio, permaneció Quiebralomo en su antigua situación, hasta el año de 18, en que el cura y los vecinos fabricaron iglesia en este sitio, sin previa licencia del orden para su construcción y bendición, y sin observar el arreglo prevenido 
por el superior Gobierno, ni el fundamento que había de población por parte de los vecinos de La Montaña, los que han edificado muchas más casas que los vecinos de Quiebralomo, pues aún el mismo señor Juez Político, ni su hermano el señor Alcalde Ordinario, no tienen casa poblada, y la Iglesia su mala construcción y materiales se halla cuasi arruinada, que se sostiene solo en los puntales con que la mantienen ${ }^{56}$.

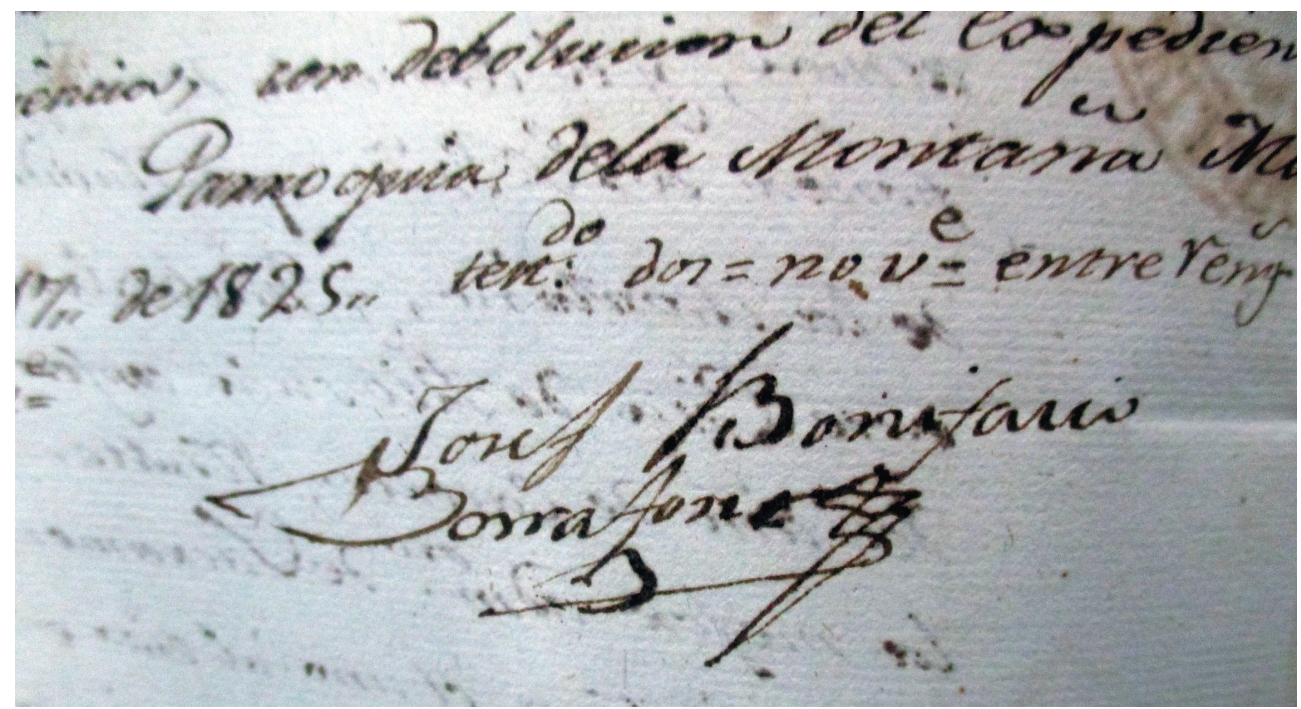

Facsímil de la carta del padre Bonafont del 17 de mayo de 1825 (Foto: Luis Caicedo)

En conclusión, el proceso de fundación de Riosucio puede resumirse en que el $\mathbf{2 8}$ de noviembre de 1814 los vecinos del pueblo de Nuestra Señora Candelaria de La Montaña y del Real de Minas de San Sebastián de Quiebralomo firmaron el Convenio de Unión para realizar el traslado de los dos pueblos y de las dos parroquias al sitio de Riosucio, y así acabar con medio siglo de conflictos entre los indígenas y los mulatos de uno y otro pueblo. La reunión fue convocada por el juez mayor de Anserma Nuevo, Manuel José Lozano, por gestión de los curas José Bonifacio Bonafont, cura de La Montaña, y José Ramón Bueno, cura de Quiebralomo. Después de la firma, el Convenio de Unión fue aprobado por el Cabildo de la ciudad de Anserma y por el gobernador de la Provincia del Cauca. Al año siguiente, el vicario general de la Vega de Supía, Andrés Ordóñez y Cifuentes, autorizó el traslado de las iglesias. El padre Bonafont trasladó su iglesia de Montaña Viejo al sitio de Riosucio en 1815, correspondiendo a la actual iglesia de La Candelaria, que fue bendecida el $\mathbf{1}^{\circ}$ de febrero de 1816; mientras que sólo en 1818 se dio el traslado de la iglesia de Quiebralomo, hoy iglesia de San Sebastián.

56 Álvaro Gartner Posada. Tras las huellas del padre Bonafont, citado. 
Es importante agregar que la fecha del Convenio de Unión (28 de noviembre de 1814) se conoce porque está mencionada en la carta del vicario Ordóñez en que autoriza el traslado de los templos.

Presbítero Doctor Andrés Ordóñez y Cifuentes, Canónigo Penitenciario de la Santa Iglesia Catedral, Provisor y Vicario General de la Vega de Supía, como habiéndosenos dirigido por la ilustre Municipalidad de Anserma, con oficio de veinticinco de enero último una acta celebrada por los vecinos de los pueblos de Quiebralomo y La Montaña en veintiocho del anterior Noviembre convocados por el Juez Mayor de aquel territorio, y con presencia de los Curas propios de ambas poblaciones, en que unánimemente convinieron en la necesidad y utilidad de trasladar ambos dos poblados al sitio de Riosucio por varias razones que aparecen en ella: cuyo convenio y resolución aprueba y recomienda dicha ilustre Municipalidad, interesándose a fin de que por nuestra parte se franquee la correspondiente licencia para trasladar ambas Iglesias al citado sitio de Riosucio $(\ldots)^{57}$.

Con el traslado efectivo de los dos pueblos y los dos templos al sitio acordado, quedó completo el ciclo fundacional, por lo cual los riosuceños convinieron en celebrar como fecha de fundación el 7 de agosto de $1819^{58}$.

57 Purificación Calvo de Vanegas, Riosucio, 1963, págs. 77 y 78.

58 Una importante contribución de esta carta a la historia de Riosucio es mostrar que la fecha de fundación de Riosucio (1819) corresponde a la época en que los pueblos y los templos de La Montaña y de Quiebralomo consolidan su traslado al sitio de Riosucio, pero que la unión como tal se pacta en 1814, año en que los padres Bonafont y Bueno eran los párrocos. Por los avatares propios de la guerra, estos curas no estuvieron presentes en Riosucio en 1819, pues para este año el primero estaba fugitivo en Arma por defender la causa patriota (como lo dice él mismo en la carta de 1825) y el segundo estaba en Bogotá rindiéndole cuentas al general Santander por la ayuda que le prestó a los realistas (esbozo biográfico del padre Bueno escrito por Julián Bueno Rodríguez). 


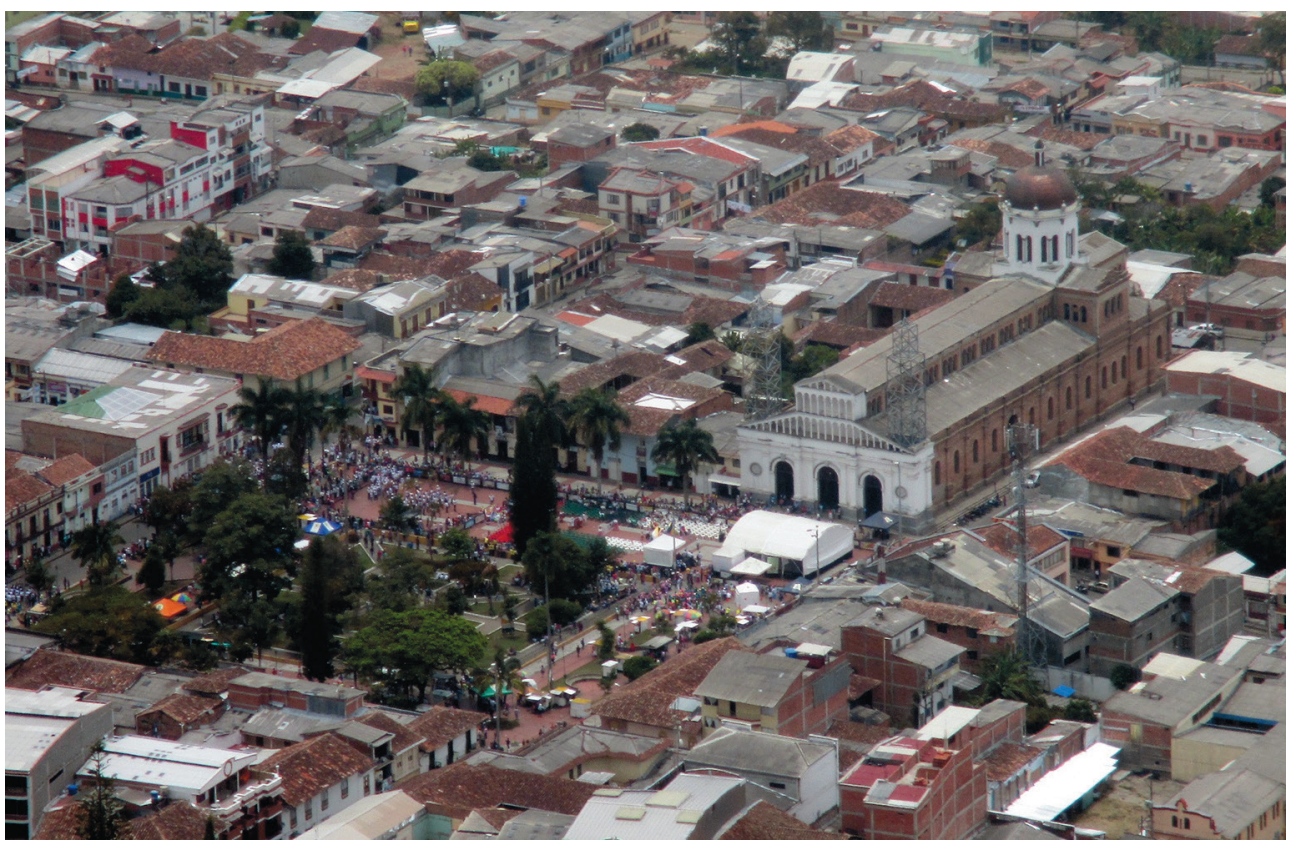

Desfile del 7 de agosto de 2015, visto desde el cerro Ingrumá.

$196^{\circ}$ aniversario de la fundación de Riosucio

Para 1917, poco antes del Centenario, cuando el viajero Rufino Gutiérrez visitó la población, ya estaba consagrada la fecha del 7 de agosto de 1819 "como la de fundación de Riosucio" 59 .

59 “En 1814 el Cura de Quiebralomo, doctor José Bonifacio de Bonafont y el de La Montaña, presbítero José Ramón Bueno, empezaron a conferenciar con el objeto de formar una sola población de las dos que administraban, y encontraron tantos tropiezos, nacidos en parte de la conducta que observaba el Padre Bonafont como decidido partidario de la independencia en lo eclesiástico y en lo civil, que solo el 7 de agosto de 1819 (fecha que los vecinos consideran como la de fundación de Riosucio) pudieron realizar su proyecto, y para ello empezaron por derribar las iglesias que había en los dos caseríos. El nuevo asiento lo dividieron equitativamente, demarcaron las dos plazas a una cuadra de distancia la una de la otra, y empezaron a construir en ellas sendas iglesias para las dos parroquias, conservando a cada una de ellas la advocación que tenía. Quedaron dos jurisdicciones en lo civil y no lo eclesiástico, y el poblado en conjunto comenzó a llamarse c, [sic] Mientras este estado de cosas subsistió, la rivalidad entre las dos ocasiones [sic], que no ha desaparecido del todo, ocasionó graves dificultades a las autoridades" (Rufino Gutiérrez. Monografías, tomo II, Biblioteca de Historia Nacional, tomo XXXVIII, Bogotá, Imprenta Nacional, 1921. Disponible en internet. Este viajero era hijo del poeta Gregorio Gutiérrez González, autor de la tesis de grado escrita en verso "Memoria del cultivo del maíz en Antioquia"). 


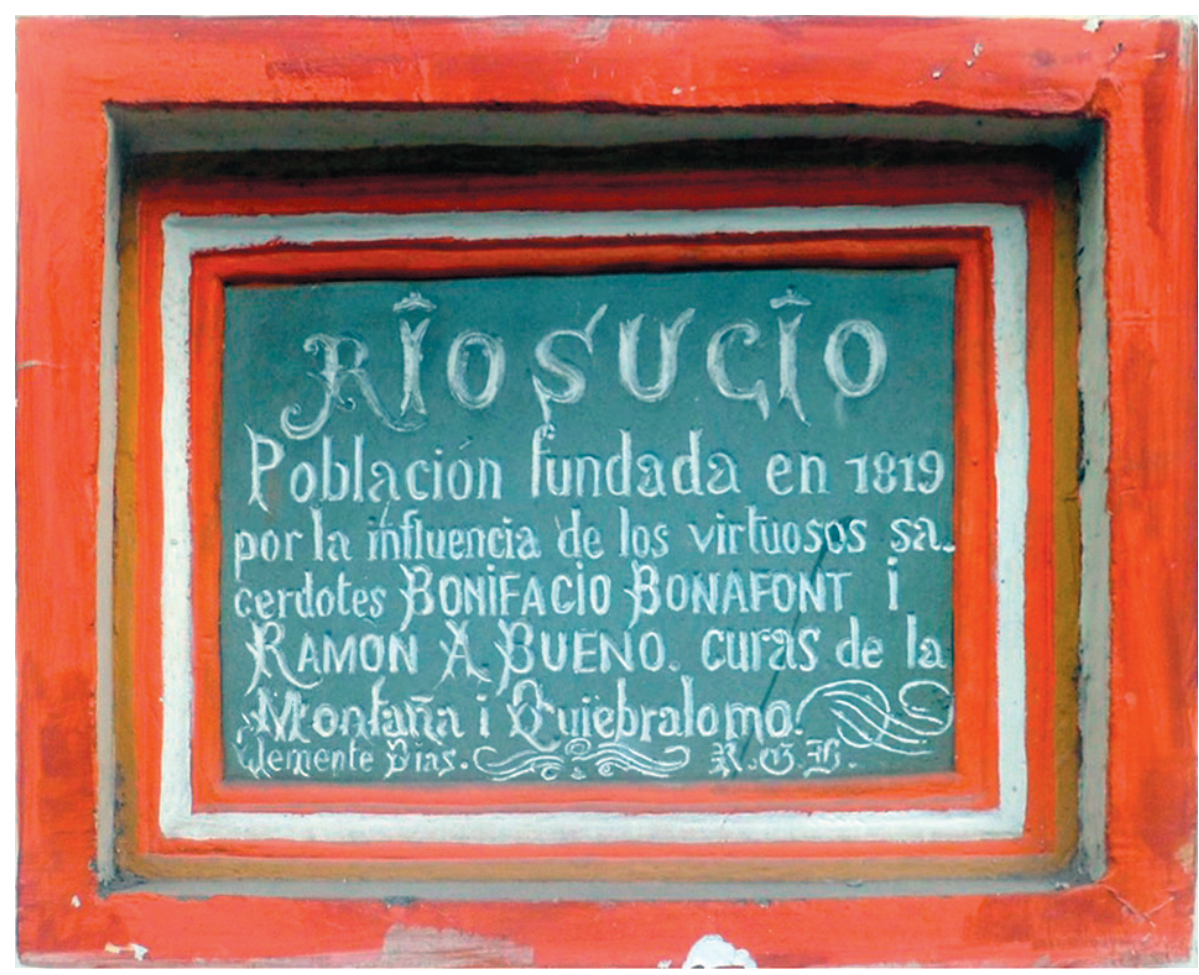

Placa ubicada en la Calle del Comercio de Riosucio.

La fecha coincide con la Batalla de Boyacá, que selló la independencia definitiva de Colombia, para simbolizar que Riosucio «floreció al amanecer de la libertad de un gran país», como lo expresa el himno del municipio:

"Honra y honor a nuestro pueblo es

La gesta de toda emancipación.

Riosucio floreció al amanecer

De la libertad de un gran país".

Este es un hecho que no se ha resaltado suficientemente: Riosucio nació al fragor de la Guerra de Independencia:

- El Convenio de Unión del 28 de noviembre de 1814 entre Quiebralomo y La Montaña se firmó cuando todavía se escuchaban los ecos de la Batalla de los Ejidos de Pasto, ocurrida el 10 de mayo anterior, en la que los patriotas salieron derrotados frente al español Juan Sámano, siendo hecho prisionero el general Antonio Nariño. 
- Cuando en 1816 regresan los españoles, Riosucio queda en la frontera de guerra entre el Cauca realista y Antioquia patriota.

- En 1819 el padre Bonafont fue obligado a exiliarse en Arma (Aguadas) y el ejército realista quemó el archivo parroquial.

- Después de la batalla de Boyacá al que le tocó irse desterrado fue al padre José Ramón Bueno.

- La región de Riosucio tenía un valor agregado, pues el oro de Marmato sirvió de garantía ante la banca inglesa para financiar la guerra, y por eso vino Boussingault a Riosucio, a cobrar la deuda.

- En 1824 un contingente de indígenas riosuceños estuvo combatiendo en la Batalla de Ayacucho (Perú).

El hecho que haya surgido de la guerra, emparenta a Riosucio con Ciudades de la Independencia del rango de Bogotá, Mompox, Ocaña o Cartagena, y que su fundación se celebre el 7 de agosto de 1819 le valió que el maestro Germán Arciniegas lo catalogara como "la imagen de la República":

¿Por qué me entusiasmo por Riosucio? Sencillamente porque en cierto modo es la imagen de la República. Es el municipio que nace en el día en que comienza realmente la vida independiente de Colombia ${ }^{60}$.

Si se fuera a dibujar el mosaico integral de los fundadores de Riosucio habría que decir que en el Convenio de Unión de 1814 intervinieron los curas de La Montaña (José Bonifacio Bonafont) y de Quiebralomo (José Ramón Bueno), así como las autoridades civiles y eclesiásticas de Anserma (Ansermanuevo) y de Popayán. Los nombres de algunos vecinos aparecen en la diligencia de notificación del permiso diocesano para el traslado de los templos (30 de junio y 3 de julio de 1815$)^{61}$.

60 García Mejía, Hernando y otros. “Germán Arciniegas a Otto Morales Benítez", en VI Encuentro de la Palabra, Manizales, Biblioteca de Escritores Caldenses, 1990, pág. 29.

61 Purificación Calvo, obra citada. 


\section{CUADRO DE INTERVINIENTES EN LA FUNDACIÓN DE RIOSUCIO}

\begin{tabular}{|c|c|}
\hline LOS FUNDI & E RIOSUCIO \\
\hline $\begin{array}{c}\text { PUEBLO DE INDIOS DE } \\
\text { NTRA SRA. CANDELARIA DE LA MONTAN̂A }\end{array}$ & $\begin{array}{c}\text { REAL DE MINAS DE } \\
\text { SAN SEBASTIAN DE QUIEBRALOMO }\end{array}$ \\
\hline $\begin{array}{l}\text { JosÉ BoNIFACIO BONAFONT } \\
\text { Cura }\end{array}$ & $\begin{array}{c}\text { JosÉ RAMón BuENo } \\
\text { Cura }\end{array}$ \\
\hline $\begin{array}{c}\text { MANUEL VELASCO } \\
\text { JOSÉ PIO GUAPACHA } \\
\text { FELIPE VINASCO } \\
\text { BERNABÉ MOTATO } \\
\text { FERNANDO MOTATO } \\
\text { EUSTAQUIO BUENo } \\
\text { FRANCISCO VINASCO } \\
\text { BASILIO GUAPACHA } \\
\text { Vecinos }\end{array}$ & $\begin{array}{c}\text { AGUSTÍN JIIÉNEZ } \\
\text { JoSÉ N. BETANCUR Y BONILLA, } \\
\text { FRANCISCO A. BETANCUR } \\
\text { RAFAEL BUENo } \\
\text { MANUEL JOSÉ CHAURA } \\
\text { PEDRO JUAN CALVO } \\
\text { JUAN PER } \\
\text { BUENAVENTURA BUENo } \\
\text { MANUEL MARIA BUENO } \\
\text { PRUDENCIA HERNANDEZ } \\
\text { SEBASTIÁN GUEVARA } \\
\text { VEcinOS }\end{array}$ \\
\hline $\begin{array}{l}\text { MANUEL JosÉ LozANo } \\
\text { Juez mayor de Anserma Nuevo } \\
\text { ANDRÉs ORDóÑEz Y CIFUENTES } \\
\text { Canónico de la catedral de Popayán }\end{array}$ & $\begin{array}{l}\text { Fuente: } \\
\text { Purificación Calvo de Vanegas. } \\
\text { Riosucio, } 1963 \text {, págs. } 77-78 .\end{array}$ \\
\hline
\end{tabular}

A este cuadro habría que agregar los protagonistas (o antagonistas) del traslado del templo de Quiebralomo en 1818: Francisco de Paula Sáenz, cura del real de minas, y José N. Betancur y Bonilla, juez político de Supía.

En cuanto a los vecinos de La Montaña y de Quiebralomo, primeros habitantes de Riosucio, se conocen los nombres de más de 300 personas cabezas de familia o solteros independientes económicamente que habitaban el naciente pueblo en $1824^{62}$. Ellos también son fundadores, porque la historia la hacen los pueblos, no los individuos.

62 Lista de contribuyentes de Quiebralomo y La Montaña para el pago de maestro en el pueblo de Riosucio en el Cantón de Supía, 1824. Transcrita en: Álvaro Gartner Posada, Tras las huellas del padre Bonafont en el Archivo Central del Cauca. Citado. 


\section{CUADRO DE FAMILIAS FUNDADORAS DE RIOSUCIO}

\section{FAMILIAS QUE HABITABAN EN EL NUEVO PUEBLO DE RIOSUCIO EN 1823}

$\begin{array}{ll}\text { Bañol } & 1 \\ \text { Bartolo } & 3 \\ \text { Bonafont } & 1 \\ \text { Bueno } & 2 \\ \text { Castro } & 1 \\ \text { Cataño } & 3 \\ \text { Chaves } & 1 \\ \text { Delgado } & 1 \\ \text { Durán } & 2\end{array}$

Fiscal
Flórez
Gallego
García
Gaspar
Guapacha
Guevara
Hernández
Ladino

Parroquia de La Montaña

$\begin{array}{lrl}\text { Alcalde } & 2 & \text { Cruz } \\ \text { Alcántara } & 1 & \text { Daraviña } \\ \text { Andica } & 10 & \text { Dávila } \\ \text { Aricapa } & 1 & \text { Díaz } \\ \text { Bañol } & 1 & \text { Escobar } \\ \text { Barra } & 1 & \text { Espinosa } \\ \text { Becerra } & 2 & \text { Flórez } \\ \text { Benitez } & 1 & \text { Franco } \\ \text { Berena } & 2 & \text { Gallego } \\ \text { Betancur } & 3 & \text { Gañán } \\ \text { Blandón } & 1 & \text { García } \\ \text { Bolaños } & 1 & \text { Giraldo } \\ \text { Bueno } & 5 & \text { González } \\ \text { Calvo } & 15 & \text { Guapacha } \\ \text { Caña } & 6 & \text { Guerrero } \\ \text { Cardeño } & 1 & \text { Guevara } \\ \text { Castro } & 1 & \text { Hernández } \\ \text { Castro } & 5 & \text { Ichimía } \\ \text { Cedeño1 } & & \text { Idárraga } \\ \text { Chaburra } & 3 & \text { Iglesia }\end{array}$

$\begin{array}{lll}1 & \text { Largo } & 12 \\ 1 & \text { Lozano } & 2 \\ 1 & \text { Machado } & 1 \\ 1 & \text { Melchor } & 3 \\ 2 & \text { Montaño } & 1 \\ 14 & \text { Morales } & 7 \\ 1 & \text { Motato } & 5 \\ 1 & \text { Nonatos } & 1 \\ 6 & \text { Pescador } & 8\end{array}$

$\begin{array}{ll}\text { Ramirez } & 1 \\ \text { Taba } & 1 \\ \text { Tabarquima } & 1 \\ \text { Taborda } & 1 \\ \text { Trejo } & 3 \\ \text { Vallejo } & 1 \\ \text { Vinasco } & 7\end{array}$

\section{Parroquia de Quiebralomo}

Fuente: Listado de contribuyentes para el pago de los maestros en el nuevo pueblo de Riosucio Tomado de: Alvaro Gartner Posada, Tras las huellas del padre Bonafont en el Archivo Central del Cauca. Elementos para una nueva visión de la fundación de Riosucio. Riosucio, 1994.

¿En qué consistieron los acuerdos de la fundación? No se ha localizado el texto del Convenio de 1814; pero la citada carta del padre Bonafont permite conocer las bases de la Unión, a saber:

a) "Que se reunieran las dos parroquias en este sitio [de Riosucio]; que cada vecindario reconociere su cura, y que todas las tierras quedaran comunes para los dos vecindarios, lo mismo que las minas, exceptuando las que fueran de propiedad de particulares, e igualmente los derechos de tierras que tuvieren legítimos propietarios".

b) Que "por lo tocante a las demás tierras usurpadas por los de Quiebralomo, está a favor de los de La Montaña el reglamento del señor Libertador, del año de 20 [Decreto del 20 de mayo de 1820], en que se manda integrar a los indígenas sus tierras, como las tuvieron en el primer repartimiento".

c) Que en el nuevo pueblo no sólo vivirían los indígenas y mulatos que le dieron origen, sino que estaría abierto al ingreso de forasteros: "Por lo que es de esperar que dentro de breve tiempo estos dos vecindarios se aumentarán considerablemente, no solo de los naturales sino también de otras gentes 
forasteras, atraídas por la fertilidad de las tierras y abundancia de minas de todos los metales.

El vicario Ordóñez, al autorizar el traslado de las Iglesias en 1815, agregó una instrucción más, que merece consagrarse como epígrafe en los Planes de Ordenamiento Territorial de todos los municipios:

Mediante a que la buena disposición de los pueblos, no solo los hermosea sino que contribuye para la sanidad y para el incremento de la población, influirá el Cura en cuanto alcance, para que los vecinos formen un poblado lucido y bien arreglado conforme a las órdenes del superior gobierno.

Un último hecho relevante de la época de la fundación, es que el mismo año que se funda el pueblo de Riosucio una avalancha arrasó con el pueblo de indios de Supía, que había sido fundado en 1627 por Lesmes de Espinosa y Saravia. La villa de San Lesmes de Supía "fue tumba de los cañamomos primero, y de la totalidad de la población en 1.819, cuando por virtud del derrumbamiento del cerro de Tacón, formó la quebrada de Rapás enorme borrasca que arrastró el caserío" ${ }^{63}$. El Parque de la Cruz, en el vecino municipio, recuerda esa tragedia, porque se dice que esa cruz detuvo el avance de la avalancha.

\section{Riosucio visto por J. B. Bousingault en 1825-1830}

Juan Bautista Boussingault (n. París, Francia, 1802 - m. París, Francia, 1887), un científico y humanista francés, llega en 1822 a la naciente Gran Colombia, entrando por Venezuela. En 1825 arriba a la Vega de Supía por el camino del Páramo de Herveo (Alto de Letras), con el fin de reactivar la explotación del oro en las minas de Marmato, Supía y Quiebralomo, que habían sido concedidas a los ingleses en pago por los empréstitos que habían otorgado los bancos para financiar la Guerra de Independencia. El mineralogista toma el naciente pueblo de Riosucio como base de operaciones, trabando amistad con el padre Bonifacio Bonafont. Son amplias las observaciones que hace en sus Memorias respecto de Riosucio, Supía, Marmato y el Chamí, en aspectos geográficos, mineros, sociales y culturales. Aquí una selección de ellas referentes a su estadía en Riosucio ${ }^{64}$ :

63 Rómulo Cuesta. Novela Tomás. Citado por Julián Bueno Rodríguez. Historia de Riosucio.

64 Boussingault, Jean Baptiste (edición original 1824). Memorias. Tomo II. Bogotá, Banco de la República, Biblioteca V Centenario, 1994. Disponible en internet. 


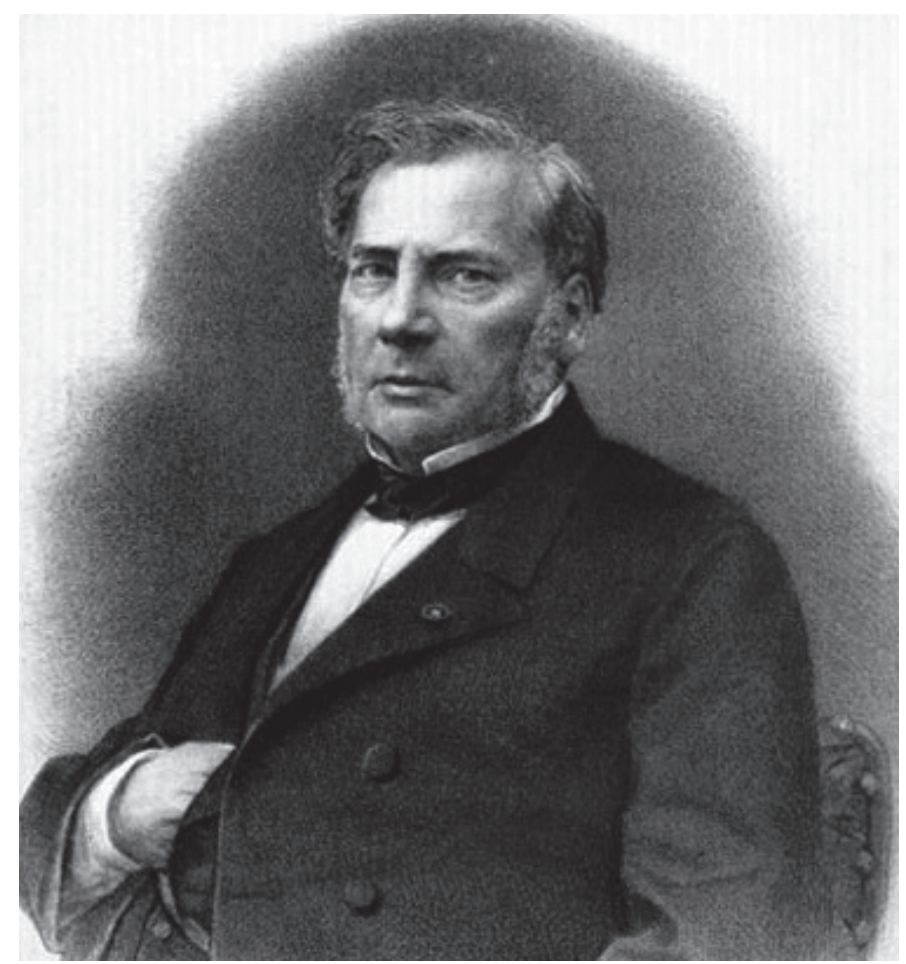

Boussingault

- «El 28 [de julio de 1825] pasé la noche en Quiebralomo y el 29 me instalé en la población, o más bien la misión de Río Sucio de Engurumí, centro de mis observaciones.

- «Yo había gastado 12 días para ir de Mariquita a La Vega [de Supía], acampando 7 veces en la selva.

- «Río Sucio, en donde me proponía centralizar las operaciones [de mejorar la minería del oro], se encuentra sobre la vertiente oriental de la Cordillera Occidental y la localidad era conveniente en relación con el clima bastante húmedo debido a la proximidad de la selva.

- «La altitud es de 1.818 metros y el promedio de temperatura de $20^{\circ}$; es una explanada poco tendida a donde llegaba por el Sur un camino que la comunicaba con Cartago; por el Norte el camino conducía a la población india de Chamí, cerca de los límites del Chocó. Río Sucio está en la base de una magnífica roca de sienita porfídica.

- «Las casas, construidas en madera recubierta de tapia, techadas con hojas de palmera, están dispuestas de manera que encierran un gran espacio, la plaza, tal como sucede en la mayoría de las misiones. La iglesia, que no difiere de las 
habitaciones sino por su tamaño, tiene una torre en donde está suspendida una campana.

- «Me alojé en una casa bastante limpia y necesariamente vacía, cerca de la cual, en una gran cabaña, pude establecer la oficina con una mesa de dibujo que fue tallada no sin dificultad, en el tronco de un árbol varias veces centenario. Me prestaron, del presbiterio, un sillón del siglo XVI, mesa de madera trabajada, guarnecida de cuero de Córdoba. Para dormir me dieron una barbacoa de guadua y en fin, pude conseguir el aparato indispensable de toda casa americana; una bella jarra de barro cocido que puede contener cerca de un hectolitro de agua y suficientemente permeable para refrescar el líquido al funcionar a la manera de las alcarrazas.

- «No estaba enterado de que hubiera minas en explotación en Río Sucio, sino muy cerca de allí, un poco más abajo en Quiebralomo (altitud 1.768 metros). Las minas que debía visitar estaban repartidas en la siguiente forma, de Oriente a Occidente:

$\bullet$

10. Quiebralomo

2o. Llanos de La Vega de Supía

3o. Marmato, Casa Morena
Altitud

1.768 metros

1.225 metros

1.474 metros.

- «Las minas de Quiebralomo eran explotadas a mano por mestizos y mulatos, a veces ayudados por un esclavo o una esclava (...)

- «En Río Sucio encontré al doctor [Desiderio] Roulin y al notario Escobar, quienes habían llegado de Bogotá por el Quindío hasta Cartago y de allí por la selva que va a lo largo del Cauca.

- «El cura de Río Sucio nos dio la bienvenida con una gran comida que se sirvió en Quiebralomo. Las autoridades municipales, toda gente de color, asistieron convenientemente vestidos aunque descalzos.

- «La cena fue pantagruélica, digna del siglo XV y tuvo lugar en una casa cubierta de teja, relativamente un palacio. Lo que sirvieron fue grandioso: se comenzó por ollas podridas (pucheros) excelentes, pero que nos hicieron sonreír porque para servirlos utilizaron vasos de noche [bacinillas] de porcelana de Wegdwood a manera de soperas, los cuales estaban vírgenes porque se ignoraba su legítimo destino.

- «Las gentes pudientes de Río Sucio habitaban en casas cubiertas de paja que formaban una gran plaza. Los pobres, los indios puros y los zambos vivían aislados en los claros de las selvas, cultivando maíz y criando gallinas; estas chacras se extendían a grandes distancias. Los días de fiesta estos dispersos 
habitantes, se reunían en el pueblo y traían sus productos: gallinas, huevos y raíces de yuca. Estas reuniones eran curiosas: cada persona tenía en su rostro un tinte característico de su raza; entre esta agrupación de familias, dignamente paseaban desnudos los indios chamis, mis buenos amigos, con los cartílagos de la nariz, las orejas o los labios adornados con anillos de oro y portando un arco o una cerbatana, con su provisión de flechas envenenadas.

- «Cuando el padre Bonafonte iba a mi casa, lo que más admiraba eran mis instrumentos; el teodolito, las brújulas, el sextante, los barómetros y los termómetros.

- «La distancia de Río Sucio a Marmato es de cerca de tres leguas en dirección occidente-oriente. Aunque las diferencias de altitud son moderadas, el espacio comprendido entre los dos puntos extremos es muy accidentado, pues el terreno es ondulado. Río Sucio se encuentra sobre sienita porfídica; se sigue esta roca más o menos modificada, más allá de Quiebralomo, en donde desaparece bajo un depósito de apariencia arenácea con partículas finas de cuarzo, de feldespatos y de anfibol, una arenisca con capas inclinadas sobre las pendientes de sienita. He vuelto a encontrar casi en todas partes esos depósitos singulares que se presentan como en pedazos. Me ha costado mucho trabajo fijar su edad y aún no lo he logrado; allí no se encuentran restos de seres orgánicos. Sin embargo, cerca de Río Sucio, se han encontrado delgadas capas de lignito; ¿serían esas areniscas arcosas derivadas de los pórfidos? Es posible. Para los mineros esta es una roca estéril, en donde jamás se encuentran filones metálicos.

- «Antes de llegar a Río Sucio, ya se está sobre el aluvión aurífero, que cubre el fondo del valle con altitudes de 500 a 600 metros por encima del Cauca.

- «Las minas son explotadas en galerías que se abren sobre el río de Santa Inés [Las Estancias] y el trabajo se ejecuta con barra, instrumento de hierro que tiene en su extremidad una punta para picar y en la otra un filo cortante, herramienta de los mineros en toda la América meridional, que manipulada por un hombre robusto, reemplaza ventajosamente los picos que se usan en Europa».

En otra oportunidad Boussingault llegó a Riosucio por el lado de Cartago, consignando observaciones de esta visita:

- "Dejé a Cartago para ir al distrito de la Vega de Supía por la selva que bordea la orilla izquierda del Cauca; este es un trayecto difícil puesto que hay que atravesa torrentes impetuosos y barrizales y además es el camino de las recuas de mulas que van de la Provincia de Popayán a la de Antioquia." 
- "Rio Sucio, a donde se llega saliendo de la selva, estaría en línea recta a 12 o 13 leguas al norte de Cartago. Sin embargo son tales las dificultades que presenta el camino, que en mula se gastan de 5 a 8 jornadas (...)"

- "Cerca de la Vega de Supía se señala un sitio conocido por la frecuencia de las caídas de rayos: es Tumbabarreto, sobre el camino de la mina de Botafuego, cerca de Quiebralomo. Aseguran que muchos habitantes habían perdido la vida allí (...)"
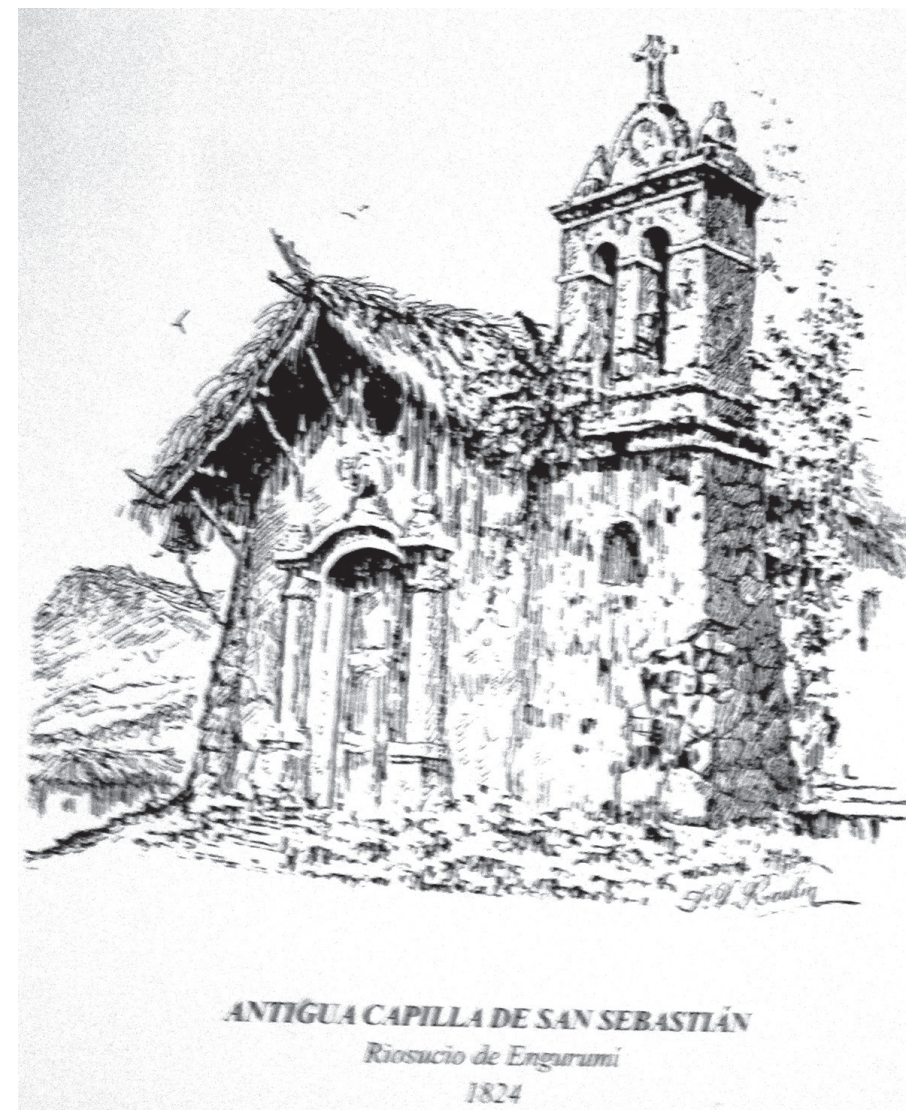

Capilla en Riosucio, 1824. Dibujo de Roulin ${ }^{65}$

En 1829 el científico francés se internó en la zona aurífera y platinífera del Chocó, entrando por Anserma Nuevo y saliendo por la misión de Chamí (hoy Mistrató). En 1830 lo cogió en Cartago la noticia de la muerte de Bolívar y el mismo año dejó el país.

65 Desiré Roulin fue compañero de Boussingault. Una copia de este dibujo se halla en la Iglesia de San Sebastián de Riosucio, cerca del altar. 


\section{El mestizaje}

En su carta de 1825 el padre Bonafont destaca que con la fundación del nuevo pueblo de Riosucio, los indios y mulatos que se juntarían en él se mezclarían y civilizarían, perdiendo su rusticidad y fiereza, proceso que se incrementaría con la apertura al ingreso de otros habitantes:

Son manifiestas las ventajas en beneficio público, pues desde la Unión de estos dos vecindarios han cesado los frecuentes pleitos suscitados por la posesión de las tierras y odios particulares conque se miraban unos vecinos con otros, de lo que resultaban riñas e injurias cuasi cotidianas; se ha aumentado la población con los muchos matrimonios que se contraen entre unos y otros vecinos; han perdido su antigua rusticidad y fiereza, se ha aumentado más la opinión de la libertad, y hoy se ven más civilizados y se presentan al público más decentes, por lo que es de esperar que dentro de breve tiempo estos dos vecindarios se aumentarán considerablemente, no solo de los naturales sino también de otras gentes forasteras, atraídas por la fertilidad de las tierras y abundancia de minas de todos los metales ${ }^{66}$.

Esta invitación abierta del padre Bonafont habría de cambiar sustancialmente la composición de los habitantes de Riosucio. El pueblo indio y mulato de 1819 recibe en sus primeros años una corriente colonizadora proveniente del Cauca (maestros, jueces, etc.) y también se establecen en él familias de orígen europeo vinculadas a la explotación de las minas de oro de Marmato, Supía y Quiebralomo. A mediados del siglo empieza la inmigración antioqueña en la zona de La Oraida. Esta transformación social se puede apreciar cien años después de la fundación al comparar los apellidos de los montañas y los quiebralomeños que componían la naciente ciudad en 1824 con las rúbricas de las personas del casco urbano designadas en mayo de 1916 como calificadores de las escuelas y colegios de Riosucio, que en ese momento llevaba el nombre de Municipio de Hispania y pertenecía al Departamento de Caldas, el que recién había sido creado en 1905, durante la reforma administrativa del general Rafael Reyes: 

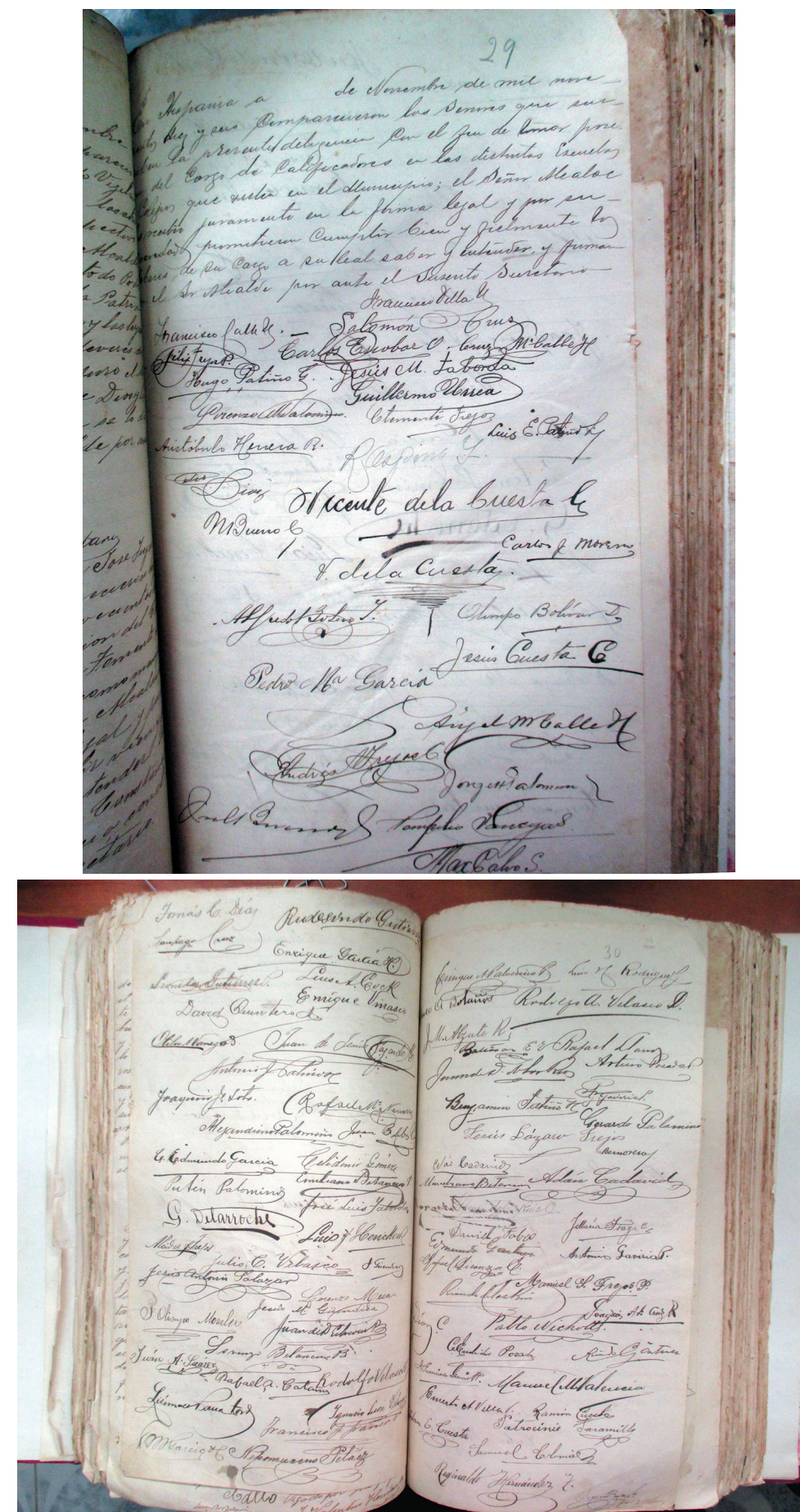

Acta de posesión de los calificadores de las escuelas y colegios del Municipio de Hispania (Riosucio), mayo de 1916 (Archivo Municipal de Riosucio. Libro de Posesiones) 


\section{Posesión de Calificadores Escolares de Riosucio en 1916}

[Hoja 29 verso]

En Hispania a [en blanco] de noviembre de mil novecientos dieciséis comparecieron los señores que suscriben la presente diligencia con el fin de tomar posesión del cargo de calificadores de las distintas Escuelas y Colegios que existen en el Municipio; el señor Alcalde les recibió el juramento en la forma legal y por su gravedad prometieron cumplir bien y fielmente los deberes de su cargo a su leal saber y entender, y firma el señor Alcalde por ante el suscrito Secretario.

Francisco Villa U.

[Los posesionados]

\begin{tabular}{|c|c|c|}
\hline Francisco Calle G. [?] & Luis E. Patiño & Pedro M. García \\
\hline Salomón Cruz & Aristóbulo Herrera R. & Jesús Cuesta G. \\
\hline Félix Trejos P. & R. Ospina Y. [?] & Ángel M. Calle H. \\
\hline Carlos Escobar O. & [Ilegible] Díaz & Andrés Trejos C. \\
\hline Cruz María Calle H. & Vicente de la Cuesta & Jorge Palomino \\
\hline Hugo Patiño G. & M. Bueno C. & [Ilegible] [tal vez: Bueno] \\
\hline Jesús María Taborda & Carlos J. Moreno & Pompilio Vanegas \\
\hline Guillermo Urrea & V. de la Cuesta & Max Calvo S. \\
\hline Lorenzo M. Palomino & Alfredo L. [?] Botero & \\
\hline Clemente Trejos & Olimpo Bolívar D. & \\
\hline & [Hoja 29 anverso] & \\
\hline Tomás C. Díaz & Alejandrino Palomino & Lorenzo Mesa \\
\hline Rudecindo Gutiérrez & Juan B. de los R [tal vez: & Jesús M. Güendica \\
\hline Sanrtiago Cruz & Ríos] & J. Olimpo Morales \\
\hline Enrique García & C. Edmundo García & Juan de D. Echeverri B. \\
\hline Leonidas Gutiérrez & Celedonio Gómez & Lorenzo Betancur B. \\
\hline Luis A. Cock & Emiliano Betancur P. & Juan A. Suárez \\
\hline Enrique Vinasco & Rubén Palomino & Rafaela Castaño \\
\hline David Quintero & José Luis Taborda & Rodolfo Velasco \\
\hline Otilio Vanegas & G. Delarroche & Lisímaco Vana Toro [?] \\
\hline Juan de Jesús Fajardo M. & Luis [ilegible] Hencken & Ignacio León Velasco \\
\hline Antonio J. [ilegible] & Alcides Trejos & Francisco J. Franco \\
\hline Joaquín F. Soto & Julio C. Velasco & M. García \\
\hline Rafael María Navarro & J. Güenberg [?] & Nepomuceno Peláez \\
\hline
\end{tabular}


Hoja 30]

\begin{tabular}{|c|c|c|}
\hline Enrique A. Palomino P. & Noé Cadavid & Ricardo [?] Gartner \\
\hline Luis M. [?] Rodríguez & Marceliano Betancur & Francisco García H. \\
\hline Francisco [?] A. Bolaños & Adán Cadavid & Manuel M. Valencia \\
\hline Rodolfo [o Rodrigo?] A. & Daniel Taba & Ernesto A. Villa \\
\hline Velasco D. & J. María Isaza C. & Ramón Cuesta [?] \\
\hline J. M. Alzate R. & Edmundo [?] Gartner [?] & Patrocinio Jaramillo \\
\hline Baltazar E. V. & Antonio Gaviria P. & Esteban E. Cuesta \\
\hline Rafael Llanos & Rafael Liranza C. [?] & Samuel Colonia N. [?] \\
\hline Arturo Posada & Manuel G. Trejos P. & Reginaldo Hernández Z \\
\hline Juan de D. [ilegible] Ríos & Ricardo de los Ríos & \\
\hline Benjamín Patiño & [Ilegible] Díaz C. & \\
\hline P. Gaviria & [Ilegible] [ilegible] Cruz & \\
\hline Gerardo Palomino & $\mathrm{R}$. & \\
\hline Jesús Lázaro Trejos & Pablo Nicholls & \\
\hline Bermoreno [?] & CeEuclides [?] Posada & \\
\hline
\end{tabular}

Total: 104 calificadores

Fuente: Libro de Posesiones. Tomo 1. 1895-1920. Archivo Municipal de Riosucio.

\section{Los nombres que ha tenido Riosucio}

Si Anserma Caldas es una ciudad de cuatro nombres (Umbra, Santa Ana de los Caballeros, San Juan y Anserma), Riosucio la aventaja: Imurrá, Riosucio, Bolívar, Polonia, Hispania, Sevilla y al parecer otro más. El mencionado viajero antioqueño Rufino Gutiérrez, que visitó Riosucio en 1917, dejó consignado en sus notas el siguiente anecdotario de nombres:

Dice la tradición que el nombre que tenía la población fue confirmado por el presidente de la República y por el obispo de la diócesis y que le fue dado porque el riecito cercano -que antes se llamaba Imurrá- lo bautizó Ríosucio el conquistador Juan de Badillo por haberlo encontrado turbio a causa de derrumbamientos en la cuchilla de Iba.

Pero los habitantes de aquella próspera población no se conforman con nombre tan prosaico y por eso han conseguido que se cambie tantas veces que solo la República le lleva ventaja en ese sentido: en documentos oficiales de la notaría se ve que de diciembre de 1856 a noviembre de 1857 se llamó distrito parroquial de Bolívar, y que después siguió llamándose distrito parroquial de Ríosucio.

La Legislatura del Cauca le cambió el nombre en 1866 por el de Polonia, en recuerdo del combate que se dio en el lugar de este nombre, en el cual 
fueron derrotados los revolucionarios, entre quienes había bastantes vecinos de Ríosucio; no sé si esa disposición fue derogada oficialmente o si le sucedió al nuevo bautizo lo que a otros oficiales que se han hecho entre nosotros, que no fue aceptado por el público, lo cierto es que siguió llamándose como antes, hasta que la Asamblea de Caldas, en 1916 por Ordenanza número 20, de 8 de abril, mandó que se llamara Hispania; pero vino la Asamblea del presente año [1917], y por Ordenanza número 20, de 21 de abril, derogó la anterior, y esto con gran sentimiento de muchos de los vecinos ${ }^{67}$.

\section{Reposición del título de San Lorenzo en $\mathbf{1 8 3 6}$}
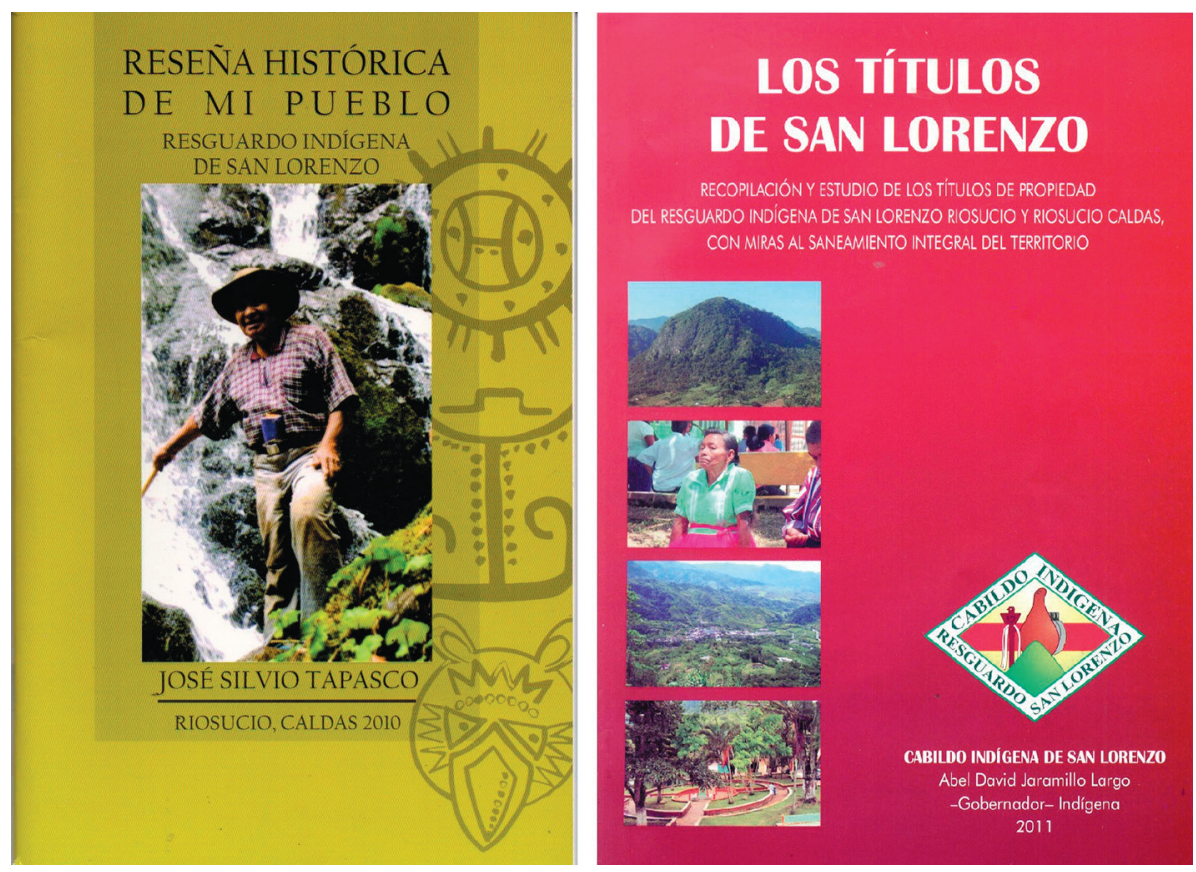

Los títulos del Resguardo de San Lorenzo

Otro hecho que ocurrió durante la época de la Independencia fue la reposición del título del Resguardo Indígena de San Lorenzo entre 1835 y 1836, el que tuvo como protagonistas al Cabildo de esta parcialidad, al comunero Juan de la Cruz Andica y al general Francisco de Paula Santander. El relato de este evento sigue el texto de la Escritura No 506 de 1920 de la Notaría de Supía, por la cual se protocolizó el título de propiedad del Resguardo Indígena de San Lorenzo del 18 de marzo de $1836^{68}$.

67 Rufino Gutiérrez, obra citada.

68 Cabildo Indígena de San Lorenzo. Los títulos de San Lorenzo, 2010. 
El pueblo de San Lorenzo venía poseyendo con tranquilidad el Resguardo que les había entregado Lesmes de Espinosa y Saravia en 1627 en la Vega de Supía a los cerca de 70 indios Sonsones que andaban sin Dios ni ley en jurisdicción de la ciudad de Arma. Pero en 1780 algunos vecinos de Quiebralomo (mulatos mineros y no indios de Cañamomo) invadieron una parte del resguardo por el lindero del río Arcón. Aunque los alcaldes indígenas hicieron diligencias de reclamo ante las autoridades españolas, ellas fueron paralizadas por la Guerra de Independencia. Cuando se estabilizó el nuevo Gobierno, los sanlorenceños reemprendieron la defensa de su territorio, pero cuando fueron en 1835 a la ciudad de Anserma Nuevo, capital de la antigua Provincia de Anserma, a buscar el título, se encontraron con que éste había sido destruido para hacer cartuchos de fusil, como lo certificó el 18 de marzo el alcalde de dicha ciudad:

Felipe Durán, Alcalde Cantonal primero de primera instancia (...) certifico (...) cómo habiéndose gastado treinta horas en este archivo en la busca de los papeles que se solicitan por el anterior pedimento no han sido hallados, por lo que se infiere los sacarían los soldados de comandante Antonio Alais en la época del año ochocientos veinte, como sucedió con muchos de los que dañaron en este archivo para hacer cartuchos, habiendo forzado la puerta.

Entonces la comunidad empezó un juicio reivindicatorio para desalojar a los quiebralomeños. Para ello tuvo primero que reconstruir el título perdido, acudiendo al efecto a presentar cinco testigos ante el Juez de Supía, quienes declararon bajo juramento la existencia del título, la posesión inmemorial y los linderos del resguardo del pueblo de San Lorenzo.

Hecha la reconstrucción judicial del título de propiedad en siete hojas útiles, la comunidad envió al comunero Juan de la Cruz Andica a Bogotá, para que pidiera la protección del Resguardo ante el presidente de la República, para entonces el general Francisco de Paula Santander, a quien Andica le escribió:

Excelentísimo señor Presidente de la Republica.= Juan de la Cruz Andica, por sí y a nombre de los demás indígenas de la parroquia de San Lorenzo, cantón de Supía, a su excelencia humildemente expongo que, aconsejado en aquella parroquia por personas notables para que viniese a la capital he emprendido un largo viaje que tiene por objeto reclamar los atentados de despojo hechos a mis compañeros en su tierras, y vistos allí indefensos anteriormente. $=[\ldots]$ En muchos lugares no se ha hecho repartimiento alguno; duermen las leyes y solo está vigilante la avaricia y el espíritu de conquista y oposición que anima a los perversos a privar a los desgraciados descendientes de los dueños primitivos de este país y parece señor que con los manejos de que informo no se olvidarán los animosos trastocamientos de los descamisados conquistadores. $=[\ldots]$ Reclamo en fin los derechos que el tiempo, la ley, la justicia y la utilidad pública nos han consagrado, y su excelencia complacerá su corazón haciendo bien a 
quien mejor lo merece.= Bogotá, tres de octubre de mil ochocientos treinta y cinco $=$.

En Bogotá el delegado indígena se entrevistó personalmente con Lino de Pombo, secretario del Interior, quien por orden de Santander comisionó la solución del caso al gobernador del Cauca. Este, a su vez, lo remitió al alcalde de Supía. El alcalde encargó del caso al Personero, y éste, en su calidad de protector de indígenas, se dirigió al Juez del Cantón de Supía pidiéndole ordenar el desalojo de los quiebralomeños:

[...] los vecinos de la parroquia de Quiebralomo no les molesten sus tierras de comunidad prohibiéndoles al efecto el que se introduzcan a las tierras expresadas a trabajar en ellas, cortar maderas y empotrerar ganados de ninguna especie, como hasta aquí lo tienen de costumbre, con violencia del sagrado derecho de propiedad de los indígenas por quienes hablo, la cual está legitimada por todos los títulos que la ley requiere, buena fe, tiempo inmemorial de posesión y justo título, que aunque no presentan, está comprobado en la adjunta documentación que solemnemente acompaño en nueve hojas útiles [...] debe ponérseles por el juzgado en una inalterable posesión de las tierras que cuestionan como único patrimonio, como el solo bien que les legó la tiranía de los conquistadores, los cuales quiere el Supremo Gobierno que se les conserve, guardándoles todas las consideraciones a que los hace acreedores su miserable condición a que los condenó la política española, de la cual quiere elevarlos nuestro gobierno en desagravio de la justicia.

Con base en esta petición, el juez de Supía abrió el respectivo proceso, para lo cual hizo fijar un cartel en el pueblo de Riosucio, que recién se había fundado:

Manuel Ángel Betancur y Bonilla.= Juez primero de primera instancia de este Cantón.= Hago saber a todos los vecinos de las Parroquias de Quiebralomo y Montaña, unidas en Riosucio, como colindantes con los resguardos de los indígenas de San Lorenzo, que habiéndose presentado el síndico personero público pidiendo se les ponga a dichos indígenas en propiedad de sus resguardos y que ninguno les ocupe sus terrenos ni en sementeras ni con crías de animales, y en vista de la orden del señor Gobernador de la Provincia y documentos que se me han presentado, designo por linderos de dicho resguardo colindando con los vecinos de la vega de Supía por la quebrada nominada Arcón, colindando con los vecinos de Quiebralomo de la boca de la quebrada de Arcón por el río nominado Supía, agua arriba hasta la boca de la quebrada nombrada Agua Salada, quebrada arriba hasta la cima de la cuchilla alta. $=$ Si hay quien represente derecho o tenga que alegar bajo esta demarcación, lo hará dentro de nueve días contados de esta fecha en adelante, en que se procederá a ponerlos en posesión de sus resguardos.= Parroquia de Quiebralomo, veinte y dos de febrero de mil ochocientos treinta y seis.= Manuel Ángel Betancur y Bonilla. 
Finalmente, no habiéndose presentado alguno a contradecir, el juez de Supía procedió el 18 de marzo de 1836 a la diligencia de renovar la propiedad de las tierras a los indígenas de San Lorenzo, así:

...yo dicho juez procedí a poner en posesión de sus resguardos a los indígenas de la viceparroquia de San Lorenzo, en la forma siguiente: Por el lado de la vega de la cuchilla alta bajando a coger la quebrada de Arcón, por esta quebrada agua abajo hasta la entrada al río Supía; río arriba hasta la boca de la quebrada Agua Salada; de esta quebrada al alto de Ipá; de éste al de Buenavista; de éste al de Sisirrá; de este a la cuchilla alta; cuchilla abajo a cerrar con el primer lindero nombrado. En cuyos punto, yo, dicho juez, mandé a los expresados indígenas pusieran buenos mojones de piedra permanentes, con lo que queda encerrado dicho resguardo [...] cuyo resguardo se le ha entregado a los interesados, quienes lo han recibido y tomado posesión en presencia del señor personero y testigos, sin haber habido contradicción ninguna de parte de los colindantes que allí estaban presentes.

\section{Erección de Riosucio en Distrito Municipal (1846), unificación de las dos parroquias y surgimiento del Carnaval}

Ganada la independencia, la nueva República abolió la administración colonial y adoptó una nueva división político-administrativa, tanto a nivel macro como a nivel local. En 1824 la extensa Gobernación de Popayán se convirtió en el Departamento del Cauca, subdividido en cuatro Provincias, una de ellas la Provincia de Popayán, que a su vez se dividió en cantones, siendo los del norte el Cantón de Toro y el Cantón de Supía. Los Cantones, a su vez, fueron subdivididos en Distritos y éstos en Parroquias. La República también abolió los "reales de minas" y los "pueblos de indios".

La naciente aldea de Riosucio quedó incluida en el Distrito de Supía, capital del Cantón del mismo nombre, y a su interior quedó conformada por dos parroquias (Candelaria y San Sebastián), separadas por una sola calle y una cerca.

Riosucio se segregó del Distrito de Supía y fue elevado a la categoría de Distrito Municipal por Decreto del 17 de junio de 1846, expedido por Laureano Mosquera, Gobernador de Popayán, por iniciativa de Pedro Alcántara Herrán, político y militar payanés, yerno de Tomás Cipriano de Mosquera, quien pasó por el lugar en 1842 en tiempos de la famosa cerca que dividía las dos parroquias y, «sorprendido entre la coexistencia de dos entidades civiles y eclesiásticas en una población aún incipiente, inició de inmediato las gestiones tendientes a unificarlas administrativamente» ${ }^{69}$. El decreto señaló los límites del nuevo distrito, pero San Lorenzo siguió perteneciendo al de Supía.

69 Julián Bueno Rodríguez, Historia de Riosucio, sin fecha, 1977 aprox. 
Pese a la importancia de este decreto (la partida de bautismo del pueblo), su texto no se consigue en Riosucio, o por lo menos no está a disposición del público.

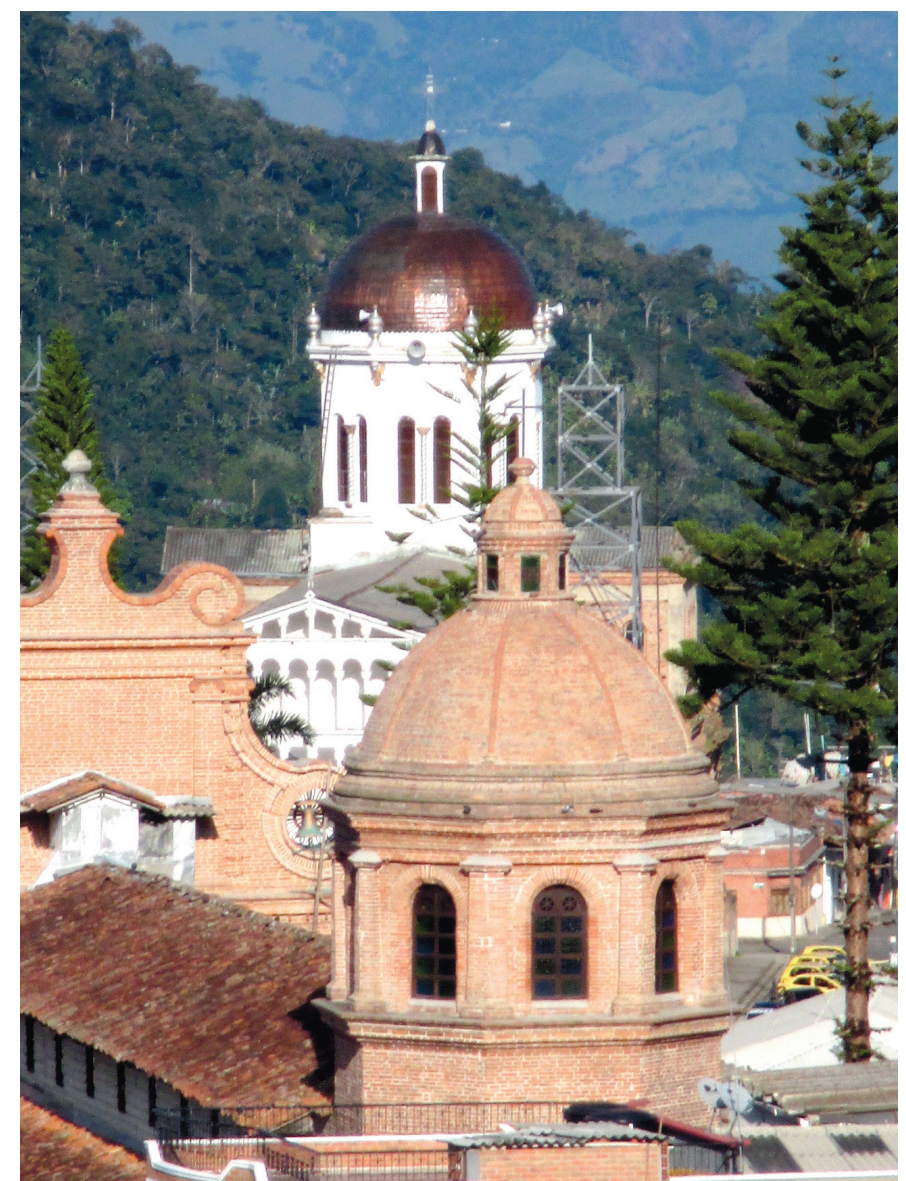

Templos de San Sebastián y La Candelaria, vistos desde la subida a Las Guacas

En cuanto a la unión de las parroquias, el ya citado Rufino Gutiérrez informa:

Por su parte el Obispo de Popayán, señor Caicedo y Cuero, dispuso el 30 de julio que aquellas dos parroquias formaran una sola con el nombre de Ríosucio, y para ello tuvo en cuenta que desde diciembre de 1845 había muerto el Cura doctor Bonafont, sacerdote de grandes méritos por sus virtudes, saber y patriotismo y mandó que la nueva parroquia quedara a cargo del presbítero Manuel Velasco, que hasta la fecha ha estado encargado de este curato con este carácter de la de Quiebralomo. El 31 del mismo mes de julio se abrieron los nuevos libros parroquiales por haberse refundido ya las dos parroquias ${ }^{70}$.

70 Op cit., Rufino Gutiérrez. 
De alguna manera se puede decir que, tras la muerte del padre Bonafont, el pueblo de La Montaña perdió la pelea frente al de Quiebralomo, que se quedó con la parroquia.

Por la misma época surgió el Carnaval de Riosucio (el Diablo, como efigie, lo hace por 1915), que desde entonces se erige como un ritual colectivo de unificación. Sin embargo, de esta unificación estuvieron excluidos en principio los antioqueños:

En 1.905, la creación del Departamento de Caldas halló seria oposición en Riosucio, pues ello significaba unirse con una sección antioqueña. Y todavía en 1.933, un matachín (José Trejos) exclamaba con sorna amarga:

Óyeme, Diablo, una cosa:

por qué hay tantos hombres blancos, bien parecidos, barbados, que parecen importados de Jericó o El Jardín?

Dime, Diablo, con qué fin trajiste gente semita, si aquí no se necesita quien nos mestice la cría? No te basta esta indiería tan bonita? por qué has puesto tánto empeño en que se mezcle la sangre de pirseña y jardineño? (...)

Piensas que es moco de pavo el injerto de indio bravo con maicera? $\mathrm{Si}$ siendo indígena puro se te montan, satanás, cuando se cruce la raza nos quemarán esta plaza y algo más ${ }^{71}$.

\section{Continuidad de los Resguardos indígenas en la República}

Simón Bolívar, Francisco de Paula Santander y el Congreso de Cúcuta fundaron un orden opuesto al colonial: el orden republicano, basado en la igualdad de los ciudadanos, tomando como prototipo de tal al "criollo", descendiente de españoles, destinado a reemplazar la organización social basada en razas, para lo cual se debía

71 Saludo del Diablo 'Polimétricas', en: Julián Bueno Rodríguez, Historia de Riosucio, sin fecha, 1977 aprox. 
extender gradualmente la ciudadanía a los negros, aboliendo la esclavitud, y a los nativos o naturales americanos, aboliendo los pueblos y resguardos de indios. Sobre estos últimos la equiparación empezó por cambiar la denominación española de "indios", que se consideraba despectiva, por la de "indígenas".

La Ley del 11 de octubre de 1821 dispuso: "Quedan abolidos los nombres de pueblos con que eran conocidas las parroquias de indígenas... En las parroquias de indígenas podrán establecerse cualesquiera otros ciudadanos, pagando el correspondiente arrendamiento por los solares que ocupen sus casas".

En cuanto a los Resguardos o tierras entregadas en comunidad por la Corona española a los indígenas, la República partió de reconocer su vigencia como propiedad colectiva $^{72}$, pero al mismo tiempo propugnó por la división o repartimiento de los terrenos entre los comuneros, para que cada indígena tuviera acceso al derecho a la propiedad privada, y así pudiera tener el pleno ejercicio de la ciudadanía (en esa época, además, sólo tenían derecho al voto los propietarios). Otra medida paralela consistió en la abolición de los Cabildos, aunque se les permitió funcionar mientras se repartían los resguardos (Decreto del 20 de mayo de 1820 del Libertador, Ley del 11 de octubre de 1821 del Congreso de Cúcuta o de la Gran Colombia, Ley del 6 de marzo de 1832 del Congreso de la Nueva Granada, etc.).

La política indigenista de la República se cumplió eficazmente en el centro del país. Para 1860 no quedaban resguardos en Boyacá y Cundinamarca, pero al costo del despojo de los nativos, quienes por su impericia en los negocios terminaron de jornaleros en sus antiguas posesiones, colonizando las tierras hacia el valle del río Magdalena o consumiéndose en las chicherías de Bogotá ${ }^{73}$.

En el occidente colombiano la situación fue diferente, ya que la Ley del 6 de marzo de 1832 permitía suspender el repartimiento de los resguardos en aquellos cantones donde lo solicitaran las provincias. La dirigencia caucana era opuesta al repartimiento aduciendo que los indígenas no estaban preparados para asumir la ciudadanía plena:

La división de las propiedades es uno de los pasos de la civilización progresiva de los pueblos [...] Pero las más bellas teorías caen a veces por circunstancias particulares en defecto, al aplicarlas a la práctica: y el estado actual de embrutecimiento de los indígenas, que en trescientos años no habían recibido de sus avarientos conquistadores otro beneficio, en compensación de tantas matanzas y esclavitud, sino el agua del bautismo; y el hallarse esta raza infeliz rodeadas de otras más inteligentes y fuertes, acostumbradas a deprimirla y

72 “Se devolverá a los naturales, como propietarios legítimos, todas las tierras que formaban los resguardos, según sus títulos, cualesquiera que sea el que aleguen para poseerlos los actuales tenedores" (artículo $1^{\circ}$ del Decreto del 20 de mayo de 1820 de Simón Bolívar). 
devorarla; hacen defectuosa por desgracia la aplicación de principios muy racionales y justos, en el caso de que tratamos ${ }^{74}$.

En 1834 la Asamblea Provincial del Cauca solicitó y obtuvo que el Gobierno Nacional suspendiera el repartimiento en todos los cantones de su jurisdicción, incluido el Cantón de Supía. La petición del Gobernador a la Asamblea expuso entre los motivos la resistencia de los indígenas a la división de sus tierras:

Desde que se publicó la ley de 6 de marzo 1832 [...] preví que aquella quedaría sin efecto, tanto por la falta de agrimensores, como porque los jefes políticos encargados inmediatamente de su ejecución, no podían contraerse a ella con la debida exactitud [...] No menos que la falta de agrimensores, presenta un obstáculo insuperable la localidad de los mismos resguardos; porque casi todas las parroquias están situadas en terrenos, ásperos montuosos e inaccesibles [...] Debo también hacer presente a la cámara que los indígenas de esta provincia han manifestado una grande oposición al repartimiento de sus resguardos, así porque su rusticidad no les deja conocer aún el beneficio que la ley les procura, como porque sus antiguos hábitos, e inclinaciones no están en consonancia con esta medida ${ }^{75}$.

Las medidas anteriores (el decreto del Libertador que en 1820 aceptó la vigencia de los títulos coloniales de los Resguardos y la suspensión del repartimiento de éstos en la Provincia del Cauca en 1834) explican la continuidad de los Resguardos indígenas en Riosucio y demás municipios de la comarca.

74 El Constitucional del Cauca, N²3, Popayán, 5 de enero de 1833, citado en Fernando Mayorga, "La propiedad territorial indígena en la Provincia de Popayán (1831-1857): continuidad del proteccionismo, situación de excepción frente a lo dispuesto en otras provincias". Revista Precedente, vol. 2, enero-junio de 2013, Universidad Santiago de Cali, págs. 73-128 (disponible en internet).

75 Carta de Rafael Diago, gobernador del Cauca, a la Cámara Provincial, 17 de septiembre de 1833, citada por Mayorga, Op cit. 


\section{El recorte del gran Resguardo de Supía y Cañamomo (1874)}

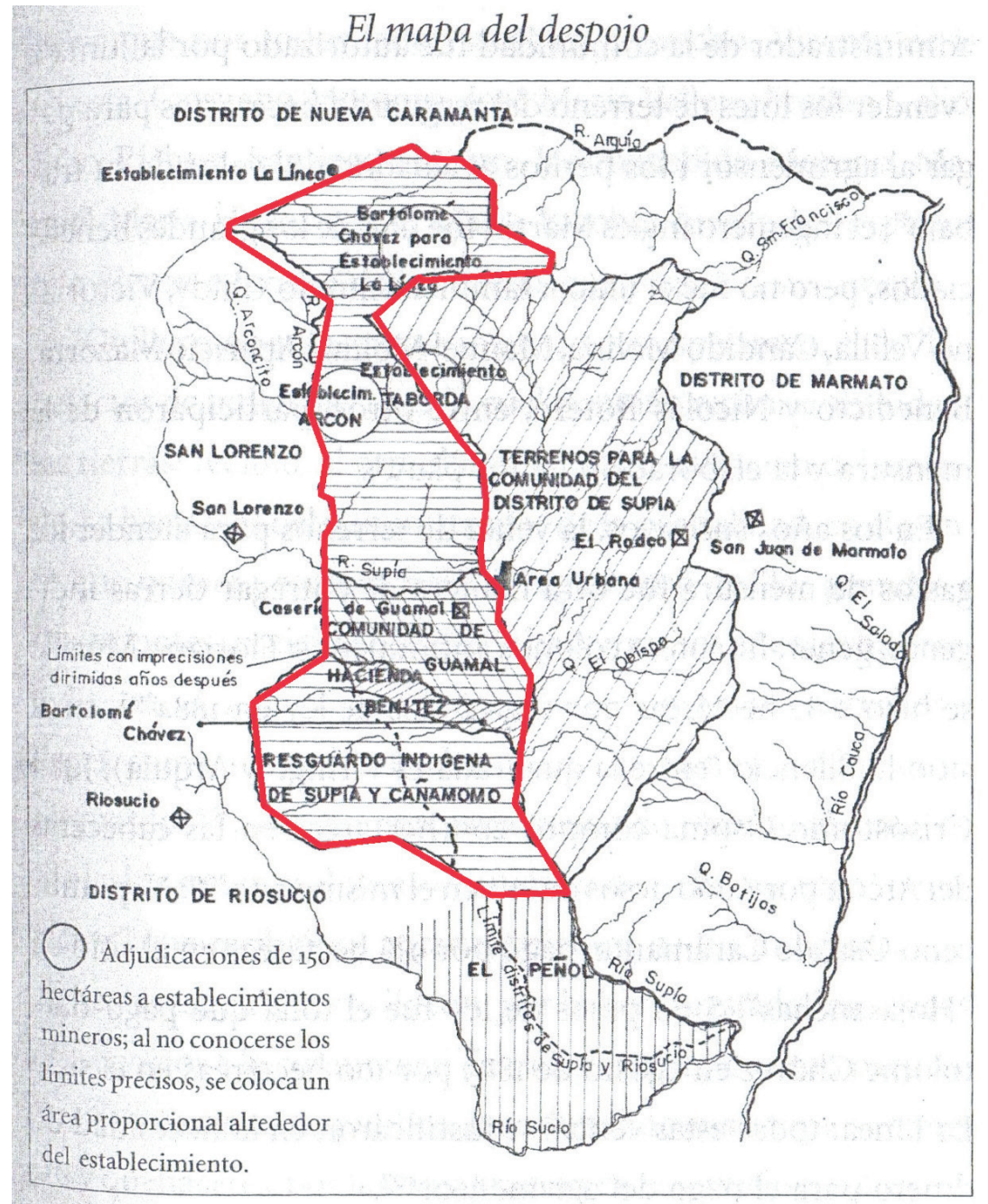

Las adjudicaciones según los arreglos de 1878. Mapa elaborado a partir de los documentos de la Notaría Única de Supía, escrituras No 10, 8 de mayo de 1878; No 43 de 1873; y No 88, 26 de mayo de 1879.

Mapa del despojo del Resguardo de Cañamomo Lomaprieta, 1874 (L. F. González) En rojo la porción que le correspondió a la Parcialidad Indígena (fuera del original)

En la época federal, la dirigencia caucana cambió de opinión, como quedó plasmado en la Ley 44 de 1873 del Estado Soberano del Cauca sobre "administración y división de los resguardos de indígenas", dictada con el objeto de poner fin a los pleitos entre los colonos y los indígenas y dar títulos definitivos a los resguardos. La ley ordenó hacer el padrón de los indígenas y la mensura de los terrenos, para darle nuevos 
linderos a los resguardos y proceder a enajenar porciones de ellos. La ejecución de esta Ley impactó de manera contundente la antigua provincia de Anserma, donde desaparecieron los resguardos de Pindaná de los Cerritos (cerca de Pereira) y Tachiguí (hoy Belén de Umbría); mientras el Resguardo de Supía y Cañamomo perdió el 80\% de su territorio.

En la Vega de Supía se unieron en uno solo los Resguardos de Cañamomo y de Supía la Baja, que Lesmes de Espinosa había constituido por separado. De ahí que para 1873 existía un gran Resguardo que se extendía desde Tumbabarreto (Riosucio) hasta el río Arquía (Marmato), con el nombre de Resguardo de Supía y Cañamomo.

Para 1874 Riosucio, Supía y Marmato están erigidos como Distritos (equivalentes a Municipios) y hacen parte de la Provincia de Toro $^{76}$. El territorio es de los indígenas hasta Marmato, pero, explica Luis Fernando González Escobar, la ocupación y el manejo del espacio han dejado de funcionar bajo el esquema colonial, abriéndose paso plenamente el orden republicano a beneficio del criollato, es decir las nuevas élites surgidas del negocio minero y de la ocupación de las tierras:

En la segunda mitad del siglo XIX todos los elementos conspiraron contra los intereses de los indígenas y en beneficio del criollato: las guerras civiles, las revueltas o alzamientos. Los idearios políticos, las leyes surgidas de los anteriores, los intereses de clase, el ímpetu comercial y minero, y el discurso de civilización y progreso del criollato; todos en su conjunto terminaron por apabullar a las comunidades, determinando el paso de lo que María Teresa Findji y José María Rojas llaman la transición de territorios coloniales a territorios republicanos ${ }^{77}$.

Este criollato no es antioqueño sino caucano. El mismo autor señala que la colonización antioqueña en el norte del Gran Cauca comenzó en forma lenta pero luego se desplegaría de forma masiva sobre los resguardos de Anserma, Guática, Quinchía y la zona alta occidental de Riosucio (resguardo de La Montaña); mientras no fue tan intensa en la Vega de Supía, donde más bien se presentó un violento encuentro de ethos entre los caucanos o "bicheros" y los antioqueños o "maiceros"78.

76 La República mantiene el régimen administrativo español de tipo provincial en la región, bajo distintas denominaciones y comprensiones jurisdiccionales: primero como los cantones de Supía, Anserma y Cartago (1824-1855); luego como los distritos de Bolívar, Supía y Marmato (1855-1863); después como la provincia de Toro (1863-1890), y finalmente como la provincia de Marmato (1890). Cuando en 1905 se crea el Departamento de Caldas, Riosucio entra a él siendo la capital de la Provincia de Marmato.

77 Luis Fernando González Escobar. Ocupación, poblamiento y territorialidades en la Vega de Supía, 1810-1950. Ministerio de Cultura. Premio de historia del Departamento de Caldas, 2002, pág. 245. Cabría agregar que la formación del "territorio republicano" en esta zona acusó una profunda ausencia del Estado central, que arbitrara los intereses de los indígenas y de las clases emergentes. 
El abogado Ramón Elías Palau, natural de Cartago, era promotor tanto del ingreso de colonos como de la enajenación de las tierras de resguardo. En 1874 era jefe municipal de Toro y en tal carácter impulsó la reestructuración del Resguardo, para lo cual contó con el apoyo del administrador de la comunidad indígena, Gregorio Trejos. Éste, con aprobación del Cabildo, y en cumplimento de la Ley 44 del año anterior, cedió el 80\% de las tierras del Resguardo, así: una parte para el Municipio de Marmato, otra parte para el Municipio de Supía y otra para el abogado. Todas estas cesiones se hicieron a título gratuito. Los indígenas no recibieron nada a cambio, al contrario, se les autorizó para que también vendieran la poca tierra que les había quedado ${ }^{79}$.

El reparto de tierras favoreció a los caucanos y a mineros tanto colombianos como extranjeros (Bartolomé Chávez, The Western Andes Mining, entre otros).

En menos de treinta años se cumplió la transición del espacio colonial al espacio republicano, en donde los indígenas quedaron reducidos a una pequeña porción territorial que representaba menos del $20 \%$ del total que tenían legalmente en el decenio de los setenta. La mayoría de tierras pasaron de tierras comuneras de indígenas dentro de un resguardo, a fincas y/o mejoras de campesinos mestizos y a grandes extensiones de 'bosques' de los terratenientes, las sociedades y los establecimientos mineros, en un distrito parroquial o municipal ${ }^{80}$.

\section{Registro de la Comunidad de Escopetera Pirza (1884)}

Son variopintas las versiones acerca del origen del nombre "Escopetera y Pirza", pero una explicación con más solidez se encuentra en el libro Historia de Guacuma, de reciente aparición:

El porqué del nombre de Escopetera y Pirza, se remonta a partir de 1860 cuando se inició la colonización antioqueña por todo el contorno del Viejo Caldas. Fue así cuando apareció una rivalidad entre dos caciques en la región de Pirza. Uno vivía en el sector de Palenque, o sea el cacique Palenque al norte del territorio Pirza y el otro en el sector de Quimbayo y que se denominaba el cacique Quimbayo, al sur del territorio Pirza. Los colonizadores antioqueños y caucanos que necesitaban apoderarse de las tierras armaron al cacique Quimbayo con escopetas hechizas o de fistol, aspecto este que colocaba en inferioridad al cacique Palenque, puesto que se vio obligado con su tribu a huir del territorio Quimbayo. Los que ayudaron a los Quimbayos a derrotar al cacique Palenque avanzaron en la usurpación de terrenos pertenecientes a los Pirzas; los Escopeteros se expandieron a un sector de terreno entre Caldas

79 Escritura No. 54 del 8 de octubre de 1874 de la Notaría de Supía. 
y Risaralda, que actualmente comprende las veredas de Ginebra, Risaraldita, Sausaguá, Trojes, El Naranjo, Sardinero, La Peña, Moreta y Mina Rica. A partir de 1884 el gobernador indígena de Escopetera, Valeriano Largo, viendo los atropellos cometidos por los colonos, buscó audiencia en los tribunales de Riosucio y Anserma para que solucionaran el problema, y fue así como un juez de Tierras de la Ciudad de Anserma, hizo el deslinde de tierras de tal forma que las dos regiones: Escopetera y Pirza hicieran parte de un solo territorio, quedando un solo título con el nombre de Escopetera y Pirza ${ }^{81}$.

Consistente con el relato anterior, Valeriano Largo, gobernador o tal vez administrador de la comunidad, promovió un proceso de deslinde y amojonamiento del territorio tradicional, el comprado en 1759, ante el Juzgado de Circuito de Riosucio. La diligencia judicial de deslinde se efectuó el 17 de octubre de 1884 y el 23 de octubre siguiente el mismo personaje la hizo registrar en la Oficina de Instrumentos Públicos de Riosucio, en cuyos libros quedó inscrita con el $\mathrm{N}^{\circ} 161$ de ese año.

161.- Hoy veinte y tres de Octubre de Mil Ochocientos Ochenta y Cuatro, se me ha presentado por VALERIANO LARGO vecino de esta ciudad, copia auténtica de la Diligencia de deslinde de los terrenos de "PIRZA Y ESCOPETERA" ubicados en este distrito, expedida por el Secretario del Juzgado de este Circuito, con fecha diez y siete de los corrientes.- En ella consta que el Juez de este Circuito, a virtud de haber promovido deslinde, la comunidad de "Escopetera y Pirza" se trasladó a dicho punto el día diez y siete de los corrientes, y dio posesión de tales terrenos a dicha Comunidad bajo estos linderos: // Del chorro de Las Cuevas, punto de partida siguiendo quebrada abajo hasta un árbol de 'Nacedero' situado en 'Piedra Ancha'; de aquí en línea recta hasta las vertientes de la quebrada de 'Congo'; ésta abajo hasta el río de Riosucio; este arriba hasta el desagüe de la quebrada 'Juan Díaz'; esta arriba hasta sus nacimientos; de aquí tomando en línea recta hasta ponerse en dirección de otra recta que partiendo de los nacimientos de la quebrada de 'Chupadero', la cual desciende de la Cuchilla del Roblal, termina en el alto a que hoy se le ha dado el nombre del 'Convenio' (en este alto descuella un árbol de dos copas que se halla en el lado izquierdo de la cañada cuando se desciende); de este punto por todo el filo de la cuchilla hasta el alto de 'Higueronal'; de aquí en línea recta al Alto de Guarva; de este en línea recta al del 'Lazo'; de aquí al de 'La Unión'; y de aquí por el filo de 'Moreta', hasta el Chorro de las Cuevas primer lindero. // Se puso la Nota respectiva al testimonio y se devolvió al presentante - Entre líneas $=$ del Juzgado= Vale. El Registrador Interino, Firmado: JUAN C. VASQUEZ.

81 Alejandro Ugarte Rico, Merardo Largo y Fernando Uribe. Historia de Guacuma. Quinchía, Risaralda, Servimpresos publicidad, 2013, págs. 20 y 21. Guacuma, por su parte, es el nombre antiguo del territorio de Quinchía, como se deduce de las Elegías de Juan de Castellanos. Los nombres de Quimbaya y Palenque corresponden a sectores del territorio de Escopetera Pirza (Palenque mudó el nombre por "El Olvido"). 
Cien años después, el Instituto Geográfico Agustín Codazzi (IGAC) delimitó la extensión de los terrenos registrados a favor de la Comunidad de Escopetera Pirza en 3.600 hectáreas:

"3.2. Análisis de la documentación. No se ha encontrado documento que dé el título de resguardo a la comunidad Escopetera-Pirza, razón por la cual no se realizó acta de deslinde, la identificación cartográfica del terreno que puede considerarse en el caso de conformación de resguardo, se basó en el registro 161 de 1884 de la diligencia de deslinde de los terrenos de la comunidad Escopetera-Pirza, practicada por un Juez del Circuito de Riosucio (...) El área en consideración, de acuerdo al registro número 161 de 1884 es de 2.446 Has, con 1.287 Has [sic] en jurisdicción del municipio de Riosucio y 1.159 Has en jurisdicción del municipio de Quinchía"82.

\section{El área de población de Riosucio (1873-1890)}

Como se ha visto, el pueblo de Riosucio fue fundado en 1819 sobre terrenos del Resguardo Indígena de La Montaña, y el padre Bonafont se encargó de recordárselo a los quiebralomeños cuando el cura de éstos le quiso quitar su parroquia:

“y por lo tocante a las demás tierras usurpadas por los de Quiebralomo, está a favor de los de La Montaña el reglamento del señor Libertador, del año de 20, en que se manda integrar a los indígenas sus tierras, como las tuvieron en el primer repartimiento" ${ }^{83}$.

En 1846 el poblado de Riosucio fue erigido Distrito o Municipio, separándolo del Distrito de Supía. Pero hasta entonces no se había separado la cabecera municipal del Resguardo.

Para separar las cabeceras municipales de las tierras de los resguardos indígenas, el Congreso Nacional, la Asamblea Provincial del Cauca y la Legislatura del Estado Soberano del Cauca, dictaron a lo largo del siglo XIX numerosas normas que establecían que los Cabildos debían segregar una parte de sus resguardos para el establecimiento y desarrollo de las cabeceras municipales, llamada "área de población", que iba desde 10 fanegadas hasta 70 hectáreas de extensión, debiendo definirse dichas áreas mediante convenio con los respectivos Cabildos indígenas (Leyes nacionales del 6 de mayo de 1832 y del 23 de junio de 1843; Ordenanzas provinciales del Cauca $\mathrm{N}^{\circ} 27$ del 6 de octubre de 1848 y N 143 del 23 de octubre de 1852; Leyes 90 de 1859

82 IGAC. "Informe de límites de la Comunidad Escopetera-Pirza. Municipio de Riosucio - Departamento de Caldas. Municipio de Quinchía-Departamento de Risaralda”. Santafé de Bogotá, 1994, págs. 6 y 15.

83 Carta de Bonafont del 17 de mayo de 1825, en: Álvaro Gartner Posada. "Tras las huellas del padre Bonafont”. citado. 
y 44 de 1873 de la legislatura del Cauca; Ley 89 de 1890) ${ }^{84}$. En particular, la Ley 90 de 1859 del Estado del Cauca dispuso:

Artículo 13.- Las Corporaciones municipales de aquellos distritos en que haya resguardos de los cuáles no se haya segregado la porción correspondiente con arreglo a las leyes para el área de población; llenarán este deber, destinando a tal objeto de diez a sesenta hectáreas, según la extensión del resguardo y las necesidades de la población.

Artículo 14.- Los indígenas que estuviesen en posesión de solares dentro del área de población serán respetados en ella. Solamente podrán ser arrendados o enajenados a reconocimiento de un cinco por ciento anual aquellos solares abandonados o que hayan permanecido incultos por cinco años antes de la adjudicación.

Artículo 15.- Los solares de que pueda disponerse serán adjudicados por la Corporación municipal al mejor postor en pública licitación; y los productos de la adjudicación serán destinados al sostenimiento de las escuelas públicas del distrito.

Segregada el área de población, la propiedad de los terrenos de dicha área de población quedaba radicada en los Municipios; y luego los Concejos y Alcaldes determinaban la forma de arrendar o vender los lotes a los vecinos.

El área de población de Riosucio sólo vino a establecerse en 1873, 54 años después de la fundación, por un convenio celebrado entre el Alcalde y el Procurador (hoy Personero) del Distrito, de una parte, y el pequeño Cabildo del Resguardo de La Montaña, de otra. Dicho convenio fue acogido por el Acuerdo Municipal número 3 del 11 de octubre de 1882, y posteriormente por el Acuerdo $\mathrm{N}^{\circ} 2$ del 8 de octubre de 1890 del Concejo Municipal de Riosucio, expedido siendo alcalde César F. Vallejo y presidente del Concejo Alejandro Palomino. Son los considerandos de este último acuerdo (único texto que se conoce de los citados) los que informan de estos sucesos cuando expresan como motivación:

« $1^{\circ}$. Que el área correspondiente a esta cabecera del Distrito o Municipio está demarcada desde el 11 de Octubre de 1882, según aparece del acuerdo num. 3 expedido por el cabildo de este Distrito, el cual hace relación al convenio celebrado el 25 de agosto de 1873 entre el pequeño Cabildo de indígenas de "la Montaña" y el Alcalde y Procurador del Distrito.

«2 ${ }^{\circ}$. Que tal área está demarcada desde entonces para esta población por los siguientes linderos: por el sur, a partir del alto denominado de los "Guerreros",

84 Normas contenidas en Fernando Mayorga, "La propiedad territorial indígena en la Provincia de Popayán 18311857”, citado, y en Álvaro José Mejía Arias, “Legislación indígena del Estado Soberano del Cauca”, inédito. 
en línea recta, hasta el alto denominado de "las Cruces", por el oriente a partir de este último punto línea recta a "Ventanita", de aquí al alto de "QuitaFresares"; por el norte de este último punto, siguiendo el filo de la cuchilla de "Tumbabarreto", hasta el alto de "Terraplén"; y por el occidente a partir de este punto siguiendo el filo de la cuchilla del "Chocho" hasta el camino que va para "El Oro" y de aquí en línea recta al alto de los "Guerreros" primer lindero.

« $3^{\circ}$ Que dentro de tales linderos hay solares libres y unas mangas cercadas sin títulos legales, puesto que el Distrito es el dueño de esa propiedad y no los ha expedido en su mayor parte» ${ }^{85}$.

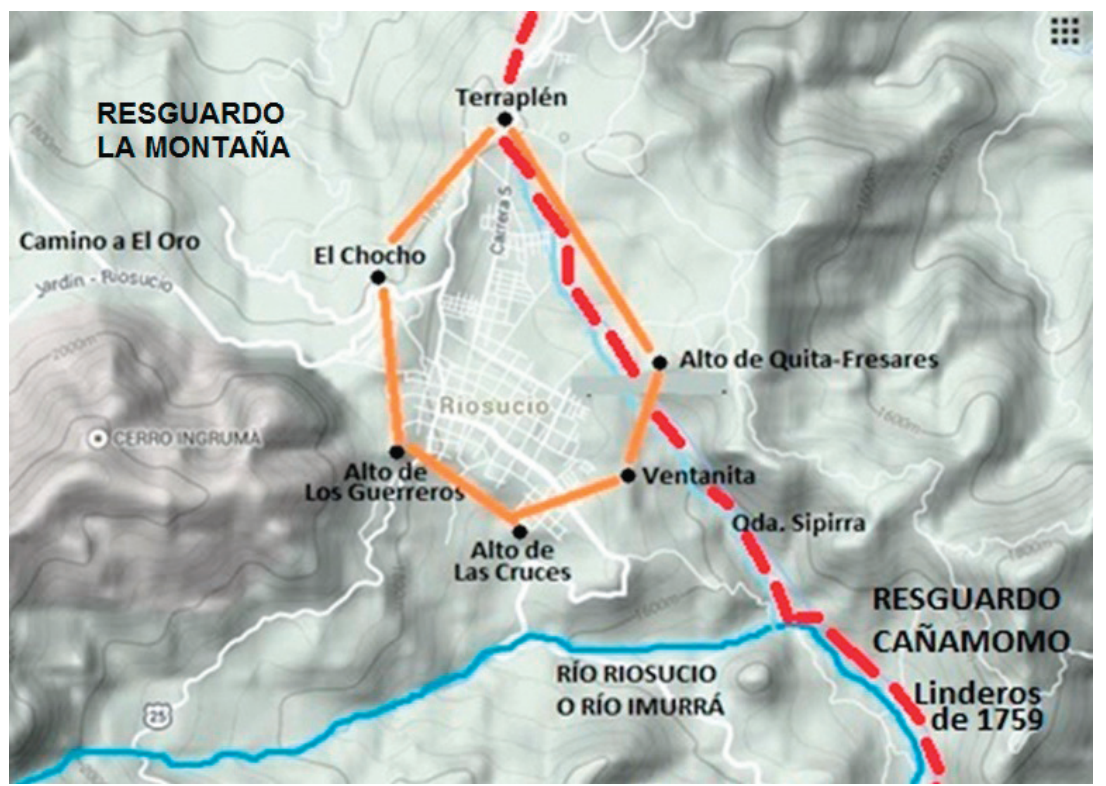

Mapa del área de población de 1890, aproximado porque los nombres de los mojones que señalan los linderos Sur y Oriente no corresponden a nombres vigentes hoy.

En su parte resolutiva, el Acuerdo $\mathrm{N}^{\circ} 2$ de 1890 adopta normas para el arreglo del poblado, como "demarcar las calles más urgentes", ordenar edificar los solares vacíos y obligar a los vecinos a costear el empedrado y cercamiento de las calles inmediatas a las plazas de San Sebastián y de La Candelaria. Igualmente reglamenta la manera de reconocer la propiedad de los vecinos sobre los lotes:

Art. $1^{\circ}$. Desde la sanción del presente acuerdo se contará un término de dos meses durante el cual todos los propietarios de fincas raíces ubicados dentro del

85 Archivo Central del Cauca. Año 1890, paquete 189, legajo 40. Popayán. Transcrito por Luis Javier Caicedo, noviembre de 2014. Este Acuerdo se encuentra copiado parcialmente en: Jaime Enrique Sanz Álvarez. Historia Judicial de Caldas. Libro primero. Manizales, sin editor, 2013 aprox. Prólogo de Otto Morales Benítez. Disponible en la Biblioteca Municipal. 
área de población indicada, presentarán los títulos en que apoyen la propiedad de tales fincas.

$\$$ - La presentación de los títulos de que habla este artículo, se hará ante el Alcalde del Municipio para que este empleado los pase al Concejo, a fin de que sean visados y refrendados, quedando anotados en un registro que en copia se pasará al empleado dicho.

Art. $2^{\circ}$. Los que no tuvieren título legal podrán presentar la prueba testimonial o sumaria, consistente en tres testigos idóneos que declaren ante autoridad competente, y que aseveren de una manera indudable que el interesado ha poseído la finca de que se trate por más de diez años sin interrupción de ninguna clase.

Art. $3^{\circ}$. Concluido el término señalado en el presente acuerdo, el Alcalde, previo conocimiento del registro que debe pasársele por el concejo, procederá a averiguar qué fincas no están incluidas en él y dará cuenta al concejo para que este resuelva lo conveniente a fin de que sean arrendadas las que queden libres en pública almoneda.

Las implicaciones del contenido de este Acuerdo Municipal serían: que desde hace más de cien años el casco urbano de Riosucio dejó de hacer parte del Resguardo de La Montaña, y que el área de población descrita en el Acuerdo 2 de 1890 constituye el fundamento legal de la propiedad privada dentro del casco urbano.

Por ejemplo, la propiedad de los terrenos sobre los que hoy se levanta el Barrio Obrero, dos cuadras detrás de la iglesia de La Candelaria, fue adquirida por Cipriano Calvo en 1891 mediante la declaración de testigos que pedía el Acuerdo 2 del año anterior para legalizar las posesiones dentro del área de población, como aparece en la solicitud que hace al alcalde, que a la sazón era Rafael Garcés:

Señor Alcalde Municipal del Distrito:

Cipriano Calvo, mayor de edad, natural y vecino de este distrito, a usted con el debido respeto digo: Que para dar cumplimiento a lo ordenado por el Concejo Municipal en su acuerdo sobre área de población, y con citación del Personero Municipal, se sirva examinar con juramento a los señores Cirilo Vallejo y Manuel A. Trejo, bajo lo siguiente:

Sobre su edad, [ilegible] y generales de la ley con el peticionario.

Digan si es verdad y les consta y lo pueden asegurar, que hace más de diez años soy poseedor en quieta y pacífica posesión de una casa pajiza con su correspondiente solar, alinderada así: por el oriente, con solar del señor Anacleto Mejía, por el norte, con el mismo señor Anacleto Mejía y con Antonio 
Flores, por el occidente con casa y solar de Pantaleón Cruz, y por el sur con una calle pública que gira de la Plaza de la Candelaria al Ojo de Agua.

Digan si es verdad que dicha casa y solar, poco más o menos, vale cincuenta pesos.

Hecho que sea, se me devuelva..."

[Recortado el final de esta página. El resaltado es fuera del original] ${ }^{86}$.

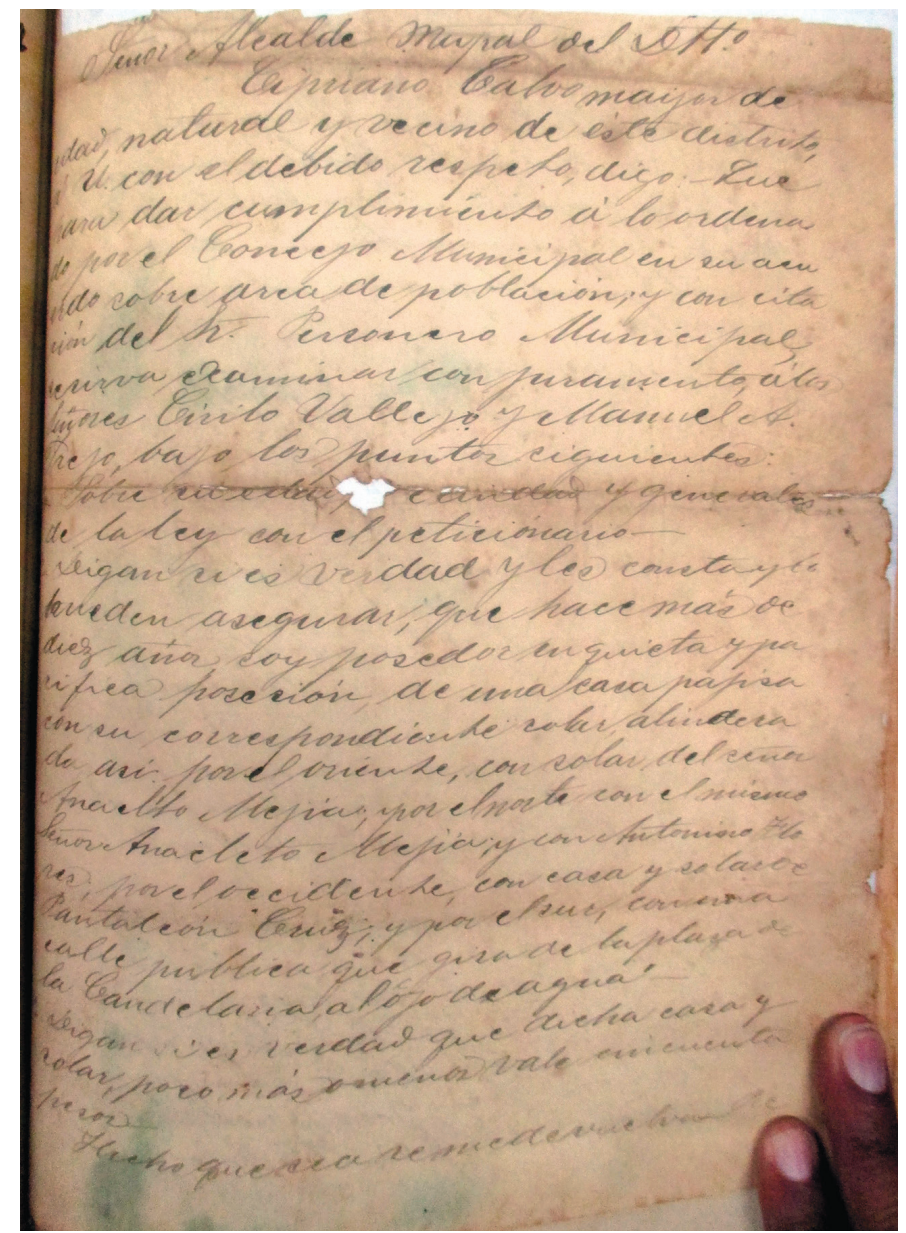

Memorial de Cipriano Calvo al alcalde de Riosucio

86 Escritura $\mathrm{N}^{\circ} 105$ del 30 de marzo de 1912 de la Notaría de Riosucio. Libro de Escrituras Públicas. Personería Municipal. Archivo Municipal de Riosucio. Otra escritura posterior sobre el mismo predio (329 de 1948) precisa que el ojo de agua que se menciona aquí es el "de la Olla" y no el del Carmen. 
La existencia del Acuerdo 2 de 1890 y el mismo hecho que en Riosucio se hubiera aplicado alguna vez la figura del "área de población" (tan común en los municipios del Departamento del Cauca) eran desconocidos. Actualmente los linderos señalados en el Acuerdo no coinciden con nombres de hitos geográficos actuales y no aparece constancia notarial ni registral del convenio de cesión de las tierras por parte del Cabildo de la Montaña.

El caso es que haber dejado de lado dicha figura es uno de los principales factores del Desordenamiento Territorial que hoy aqueja al municipio, en que no se sabe dónde termina el casco urbano y dónde comienzan los resguardos indígenas.

\section{La colonización antioqueña, la Oraida y el pueblo de El Rosario}

A partir de la fundación de Sonsón en 1800, se erigen sucesivamente Abejorral, Aguadas, Pácora, Salamina, Aranzazu, Neira y Manizales (1848) en la margen derecha del río Cauca, antiguos territorios de la Provincia de Arma, cooptados por Antioquia en 1783. De ahí los colonos siguieron para el Tolima, el Quindío y el Valle del Cauca. Para mediados del mismo siglo otra oleada de colonización penetró en el Estado del Cauca por el Municipio de Riosucio.

La colonización antioqueña operó sobre ambas bandas del río Cauca. La diferencia entre uno y otro proceso radica en que a la derecha del río los pueblos indígenas habían desaparecido hacía 200 años y los colonos se enfrentaron a selvas deshabitadas (salvo la población de Arma), dando lugar a legendarias gestas fundacionales, ampliamente estudiadas ${ }^{87}$. La margen izquierda del río Cauca, en cambio, estaba habitada por varias parcialidades indígenas y existían distritos municipales organizados de vieja data.

87 Otto Morales Benítez. Testimonio de un pueblo. Bogotá, Antares, 1951; Jame Parsons. La colonización antioqueña en el occidente colombiano. Medellín, Imprenta departamental de Antioquia, 1950, con prólogo de Emilio Robledo; etc. Los armeños se resistieron en solitario y hasta donde pudieron a perder los derechos sobre las tierras de la antigua ciudad, activismo que se expone en: Ricardo de los Ríos Tobón. Historia del Gran Caldas, volumen 1, orígenes y colonización hasta 1850. Biblioteca de Autores Caldenses. Manizales, Imprenta Departamental, 1983. 


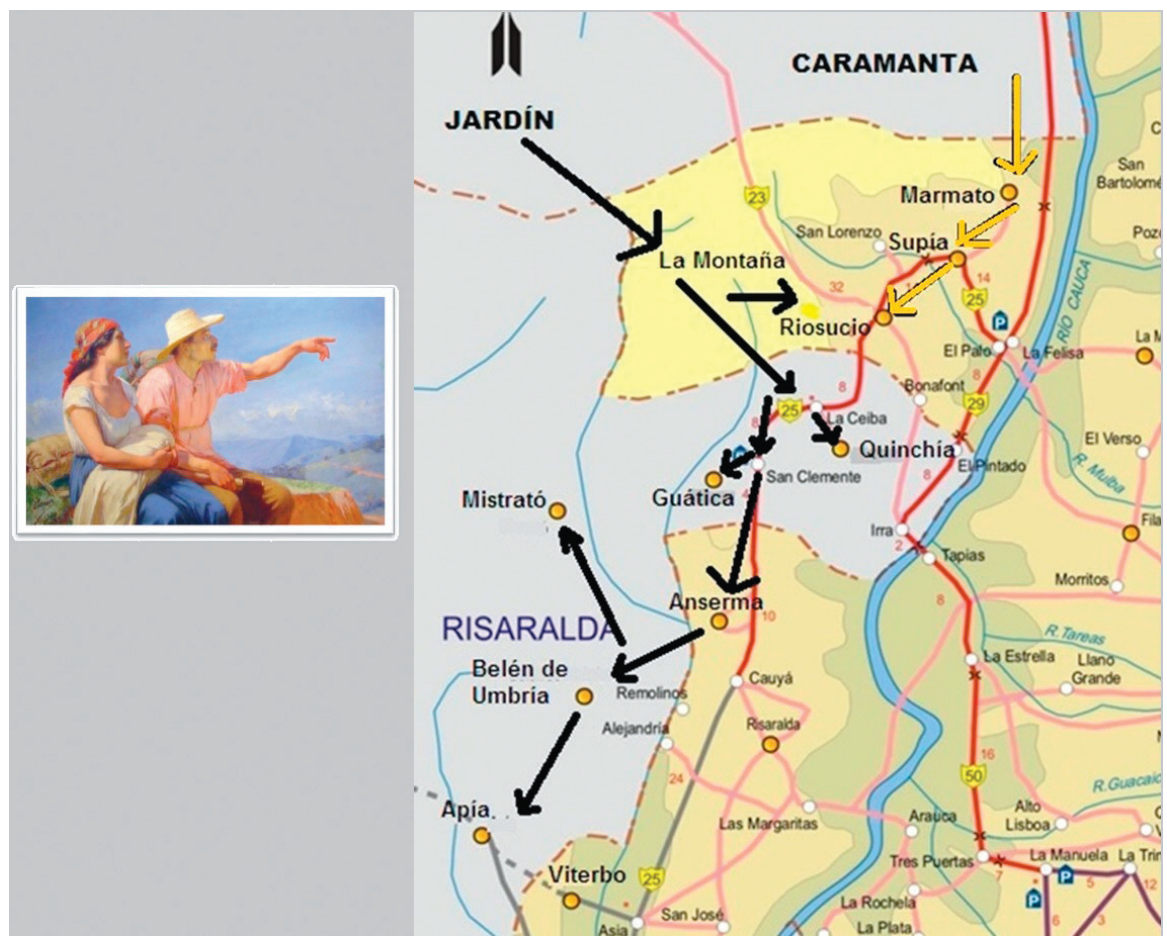

"Horizontes", óleo de Francisco Antonio Cano, 1913. Museo de Antioquia, y mapa de la colonización en el occidente del Viejo Caldas

Los nuevos colonos traspasaron la frontera caucana abriendo camino desde el Municipio de Jardín y entraron a Riosucio por la parte alta del Resguardo de Nuestra Señora Candelaria de la Montaña. Partiendo de allí, la colonización se desplazó hacia los resguardos de Quinchía, Guática, Anserma y Chamí. La dirigiencia riosuceña, de origen caucano, estimuló el avance de los nuevos colonos.

Alfredo Cardona Tobón relata cómo la colonización en la banda izquierda del río Cauca o antigua provincia de Anserma comenzó con la aldea de la Oraida en Riosucio:

Como lo afirma Boussingault en sus memorias, mineros antioqueños llegaban a trabajar por temporadas, hacia el año 1825, en las minas de Marmato; permanecían un tiempo y luego regresaban a su tierra sin establecerse en la zona.

Los primeros paisas que entraron para quedarse en la zona lo hicieron por la tierra fría del Resguardo de La Montaña [Riosucio]. Fueron barequeros y ganaderos que con la aquiescensia de las autoridades del Cantón de Supía ocuparon tierras ajenas pertenecientes a los indígenas de La Montaña y por el año 1843 fundaron el caserío de Oraida, que fue erigido en Aldea en septiembre 30 de 1954. Los primeros pobladores de Oraida llegaron de las poblaciones de 
Andes, Támesis, Carmen de Viboral y de Marinilla con apellidos Jaramillo, Naranjo, Navarro y Hoyos ${ }^{88}$.

El mismo autor explica cómo desde Riosucio se le sacó provecho político al asentamiento de la Oraida, lo que añade un elemento más a los móviles estudiados de la colonización: la pobreza unida a la fecundidad de los primeros campesinos que parten hacia el sur, y el ánimo de lucro de los empresarios que salieron detrás de ellos:

Clemente Díaz y otros dirigentes conservadores de Riosucio, entonces capital de la provincia de Toro, apoyaron la colonización de la gente de Oraida y en la década de los setentas del siglo XIX trajeron numerosas familias labriegas de Carmen de Viboral y de Marinilla de claro ancestro conservador para darle aliento a Pueblo Nuevo [luego San Clemente], erigirlo en corregimiento y establecer en ese punto una cuña paisa y conservadora en medio de los resguardos liberales de Quinchía, Guática y Arrayanal ${ }^{89}$.

Otro hito de la colonización antioqueña en Riosucio lo constituye el pueblo de El Rosario, hoy llamado "Pueblo Perdido", cuya fundación es narrada en el periódico Hola Riosucio, cercano a la Corporación Encuentro de la Palabra:

Todos los riosuceños crecieron conociendo la leyenda de que en la 'Tierra Fría', allá donde llegaron los antioqueños a buscar mejor vida, existió un pueblo próspero y grande que murió por causa de una maldición y terminó consumido por la maleza. Dice la tradición oral que el sacerdote Marco Antonio Tobón, presionado por escándalos sexuales y por los celos e intereses politicos de los riosuceños que veían con desconfianza el florecimiento de la naciente aldea, debió abandonar El Rosario y 'al sacudirse el polvo de sus zapatos' condenó a la comarca a ser 'un rastrojero enlagunado'.

Es verdad que el Padre Tobón debió abandonar la aldea de El Rosario y que su fundador, el supieño Rafael Tascón, debió vender o ceder sus derechos sobre esas tierras y establecerse en Anserma Viejo, con lo que se perdió el impulso con el que habia arrancado la población. Más que una maldición provocada por los chismes de alcoba del presbítero, lo que ocasionó el languidecimiento del pueblo fue la separación física de Riosucio, su dificil acceso y el bloqueo al que lo sometieron los dirigentes de la región al observar con desconfianza que familias antioqueñas, algunas de filiación liberal, se establecieran en su

88 Alfredo Cardona Tobón. "La ocupación paisa de los resguardos indígenas del norte caucano”, conferencia leída en el Congreso La Colonización Antioqueña, Medellín 5 al 8 de junio de 2015. En: Repertorio Histórico de la Academia Antioqueña de Historia”, Año 109, Núm. 30 (Nueva Etapa). Julio-septiembre de 2015, págs. 119-130. Disponible en internet. Una de las conclusiones de la mesa coordinada por José Nevardo García Giraldo en este Congreso consistió en que "Igualmente hacen falta más estudios sobre el impacto de esta colonización sobre las comunidades indígenas existentes en los territorios colonizados” (Ídem, pág. 186), 
territorio y progresaran. Sumado a lo anterior la hostilidad de los indígenas de La Montaña, quienes aunque en un principio consintieron en su fundación, con el tiempo empezaron a dudar de las 'buenas intenciones' de los colonos blancos.

\section{Por los lugares de Riosucio - El Rosario}

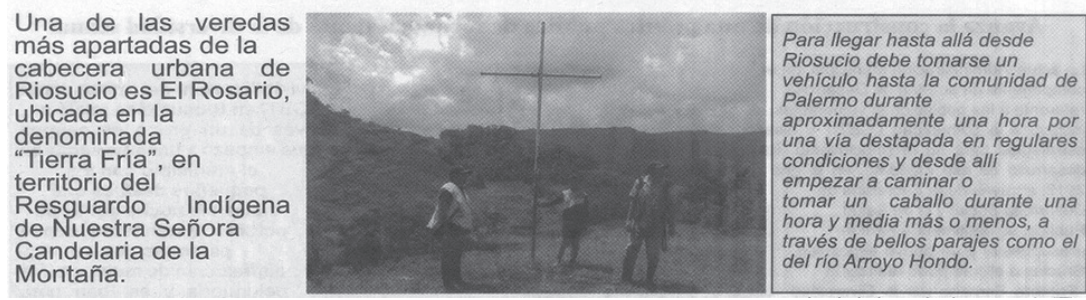

Crónica sobre El Rosario, paraje conocido hoy como "Pueblo Perdido"

La fundación de El Rosario data de finales del siglo XIX. Rafael Tascón de la Roche, hijo de Francisco Senén Tascón Londoño, el hombre dueño de minas e importantes negocios que tuvo un banco particular en Supía, adquirió las tierras de la parte más alta de la cordillera occidental del territorio del Cabildo de La Montaña a través de compra efectuada a los indígenas, negocio que si bien fue consentido por los nativos, violó la ley que prohibía la compra y venta de los derechos sobre las tierras de los resguardos.

Al parecer, la motivación de los dirigentes del cabildo para vender su tierra, pese a la prohibición legal, se debió a que ese territorio se lo disputaban con el Cabildo de Arrayanal [actual Mistrató, Risaralda] y creyeron que los colonos blancos ayudarían a controlar sus fronteras. Sin embargo, el establecimiento de El Rosario atrajo a decenas de familias antioqueñas que llegaron para terminar de despojar de sus tierras a los indigenas y ese lugar pasó a depender exclusivamente de personas ajenas a la Parcialidad.

Los conflictos con los indígenas por la posesión de la tierra y por el afán de instaurar a las malas las costumbres de los blancos generaron fricciones $\mathrm{y}$ violentos enfrentamientos entre los nativos y los colonos, los que fueron aplastados con 'mano dura' por parte del Inspector de Policía, curiosamente hermano del Padre Tobón. Además la dirigencia conservadora de Riosucio veía con recelo el progreso de esa alejada comarca y temía a la prosperidad de conservadores progresistas y liberales en esa región, por lo que buscaron bloquearla por todos los medios.

En 1906 Rafael Tascón fue nombrado Prefecto (Alcalde) de Riosucio y debió trasladarse a la cabecera urbana, en donde sufrió un atentado con dinamita que lo hizo abandonar sus intereses en El Rosario y partir hacia Anserma en donde murió en la pobreza en 1926. 
El Padre Tobón también debió abandonar el pueblo por la inseguridad, los rumores y las presiones, seguido de las familias antioqueñas que le dieron origen. El pueblo se marchitó para siempre, dando lugar a la leyenda de la maldición que todos los riosuceños conocemos ${ }^{90}$.

La investigadora Nancy Appelbaum aporta nuevos datos a esta historia. Escribe que en 1895 Justiniano Pescador, gobernador del Resguardo de La Montaña proponía cercar o construir una pared en una gran parte del resguardo

para cortar e impedir la grande, arbitraria y notable usurpación que los particulares de aquí y muy especialmente de varios oriundos del departamento vecino de Antioquia hacen de los terrenos de nuestro resguardo, sin legítimo título de propiedad, adueñándose arbitrariamente de varias porciones de él ${ }^{91}$.

Pero un par de años después el gobernador suplente autorizó el ingreso:

En 1898 el negociante de tierras Rafael Tascón compró derechos del resguardo de indígenas en forma individual y en 1899 presentó una solicitud al cabildo para que se le otorgara el lote que se encontraba en la esquina noroccidental del resguardo. El documento notarial, por medio del cual el cabildo aprobó el loteo de tierra a Tascón, consistió en la acta escrita de una reunión oficial del cabildo, presidida por el Gobernador Suplente, Braulio Largo. Al aprobar la asignación de tierra a Tascón, el documento se refiere a él como a un 'accionista en los terrenos del resguardo de la parcialidad, por compra que ha hecho de derechos a indijenas legalmente reconosidos' [sic]. Parece que este acuerdo violó la Ley 89 la cual había prohibido la compra y venta de derechos del resguardo.

El documento del cabildo también sostenía que la tierra asignada a Tascón no había sido ocupada por comuneros. Más aún, el documento señalaba que el Señor Tascón 'ha fomentado...el Establecimiento de la población de El Rosario, situada en la porción de terreno que ocupa, con lo cual los terrenos del resguardo en jeneral ha aumentado el valor produciendose asi un benefisio, a los intereses de la Parsialidad' [sic ${ }^{92}$.

90 Sin autor. “Por los lugares de Riosucio. El Rosario”, en: Hola Riosucio. № 3. Riosucio, junio 2015.

91 Nancy Appelbaum. Dos plazas y una nación, Raza y colonización en Riosucio, Caldas, 1846-1948. Bogotá, U. del Rosario / U. de los Andes, 2007.

92 Nancy Appelbaum. "Las parcialidades indígenas de Riosucio y Quinchía frente a la Ley 89 de 1890 (18901920)", tradución de María Monterroso, en: Impronta, órgano de la Academia Caldense de Historia, 14 de julio de 2011(http://academiacaldensedehistoria.blogspot.com.co/2011/07/las-parcialidades-indigenas-deriosucio_14.html). 
La penetración antioqueña no fue ajena a la observación de los viajeros. Por ejemplo, Alfred Hettner, quien recorrió la región entre 1882 y 1884, describió el estado en que encontró la antigua provincia de Anserma, en especial desde el punto de vista étnico:

Marmato y sus alrededores tienen para su desarrollo el único freno de no pertenecer al Estado de Antioquia sino al del Cauca, muy decaído como tal (...)

Un ciudadano británico, que era residente de la región hace unos decenios, me había pintado a Riosucio como puro pueblo indio. Pero gracias a la inmigración antioqueña, que pasando por la frontera de su Estado, venía penetrando al del Cauca, desde entonces debido a su empuje aquellos pueblos indios han despertado de su estancamiento. Comparado con el interior de Antioquia, con su mezcla casi completa entre blancos e indios, aquí estamos ante el inusitado fenómeno de vernos enfrentados a un alto porcentaje de indios puros o poco mezclados. Recordando mis observaciones hechas en los pueblos de la Cordillera Oriental, habría esperado todo lo contrario.

La aldea de Quinchía, situada media jornada al sur de Riosucio, todavía se halla en el estado antiguo descrito, es decir, de casi puro pueblo indio, caracterizándose por su estructura nada común, de una sola vía de larga extensión, con una iglesia de aspecto pobre, construida a su final al través de la vía, para así dejarla como callejón sin salida. No hace mucho había venido el primer antioqueño para establecer su tienda en el pueblo y ganar pronto, gracias a su experiencia e inteligencia sobresalientes, marcada influencia sobre sus conciudadanos.

En cambio, a Ansermaviejo, ubicado a otra media jornada hacia el sur, los antioqueños todavía no han penetrado. Población antigua, fundada por los españoles en 1539 bajo el nombre de Santa Ana de los Caballeros, fue abandonada más tarde por una parte de sus habitantes, presentándose hoy como localidad miserable, llena de pasto su plaza y con caballos y burros como comensales nocturnos $(\ldots)^{93}$.

\section{La Ley 89 de 1890 y las aprensiones de San Lorenzo}

El siglo XIX termina con la expedición de la Ley 89 de 1890, que había sido precedida por un ambiente de zozobra en las parcialidades indígenas del abolido Estado Soberano del Cauca. Cuando finalizó la Guerra Civil de 1885, el presidente Rafael Núñez (liberal pasado a conservador) declaró abolido el sistema federal y tramitó la expedición de la Constitución de 1886, que centralizó el país. En Riosucio, los

93 Alfred Hettner. "Viaje por los Andes colombianos (1882-1884)", en: Viajeros por el antiguo Caldas, Academia Caldense de Historia, 2008. También disponible en: http://www.banrepcultural.org/blaavirtual/historia/viaand/ viaand29.htm 
indígenas de San Lorenzo, que eran liberales, temiendo que la Regeneración acabara su Resguardo, puso sus terrenos en comunidad civil, mediante la Escritura $\mathrm{N}^{\circ} 93$ de 1889, otorgada ante el notario de Supía, del Circuito de Toro, en la que se lee:

Expresan los otorgantes aquí presentes: que como en virtud de la nueva legislación del país vinieron a quedar vulneradas las leyes sobre protección de indígenas y sujetas por eso mismo éstos a iguales condiciones de gente civilizada, aunque por otra parte la causa de la expedición de aquellas benéficas leyes no haya desaparecido de la mayor parte de tribus de raza indígena que aún existen diseminadas en Colombia, muy especialmente en el territorio caucano, han resuelto de su libre y espontánea voluntad organizase en comunidad por medio de la presente escritura, con el exclusivo fin de dar carácter legal a su entidad y seguir explotando en conjunto el lote de terreno que les corresponde por herencia de sus mayores, con la misma libertad, derechos y obligaciones con que lo han poseído y explotado desde tiempo inmemorial, bajo las bases y condiciones que van a expresarse (... ${ }^{94}$.

Las dudas se despejaron con la expedición de la Ley 89 de 1890, "por la cual se determina la forma como deben ser gobernados los salvajes que vayan reduciéndose a la vida civilizada", la cual organizó el régimen de Parcialidades, Resguardos y Cabildos indígenas para la República unitaria, siguiendo el texto de la Ley 90 de 1859 del Estado del Cauca ${ }^{95}$. La nueva ley nacional concedió un plazo de 50 años a los indígenas para que se integraran a la vida civilizada, bajo el gobierno de la Iglesia, vencido el cual los Resguardos debían dividirse entre los comuneros. Mientras tanto, los indígenas seguirían siendo considerados menores de edad, que requerían autorización judicial para vender sus parcelas dentro del Resguardo, so pena de nulidad de las ventas.

Sin embargo, esta ley no tuvo la suficiente eficacia para garantizar la integridad de los Resguardos indígenas en Riosucio y demás distritos del norte del Gran Cauca. Fue como si se aplicara el célebre aforismo español de "Se obedece pero no se cumple", como concluye la investigadora estadounidense Nancy Appelbaum:

Los funcionarios e inversionistas locales de Riosucio no lograron derogar la Ley 89 de 1890, pero sí hallaron la manera de eludirla y de estirar sus límites con el fin de aprovechar el auge cafetero y el incremento en la demanda nacional de productos agropecuarios (...) En Riosucio, sin embargo, las instancias locales del Estado -alcaldías, juzgados, y otros funcionarios- mostraron ser inconsistentes, en el mejor de los casos, en imponer la legislación protectora.

94 Los títulos de San Lorenzo.

95 Sobre los antecedentes legislativos de la Ley 89, véase: Fernando Mayorga García. "Norma general, norma especial: el Código Civil de 1887 y la Ley 89 de 1890. Un caso de regulación protectora de las minorías durante la Regeneración", en: Revista Mexicana de Historia del Derecho, $\mathrm{N}^{\circ} 27$, UNAM, Instituto de Investigaciones Jurídicas, 2013. 
En el ámbito local no fue el Estado el mejor guardián de los intereses de los indígenas, por la sencilla razón de que estaba controlado por personas que sentían que la legislación indígena iba directamente contra sus intereses (...) Los mismos individuos que invertían en tierras y en minas controlaban también las cortes [juzgados] locales ${ }^{96}$.

96 Nancy Appelbaum. Dos plazas y una nación, Op cit. 

SIGLO XX 

La creación del Departamento de Caldas (1905). Escopetera Pirza se separa del Resguardo de La Montaña y elige Cabildo propio (1913). Monografía de Riosucio en el Centenario. El proyecto nacional para disolver los resguardos indígenas coloniales, empezando por los de Riosucio y en particular por San Lorenzo (1939-1943). La posición de los Cabildos de Riosucio frente a la disolución (San Lorenzo, Nuestra Señora Candelaria de la Montaña, Cañamomo Lomaprieta, el caso de Escopetera Pirza). Visita antropológica de Luis Duque Gómez a Riosucio en 1943. La reforma urbana de los años treinta a cincuenta y sus efectos sobre la existencia de los resguardos. Del cambio de política indigenista del Estado en 1958 a la Constitución de 1991.

\section{La creación del Departamento de Caldas (1905)}

El fenómeno de la colonización antioqueñallegó a su punto más alto bajo la presidencia de Rafael Reyes con la creación del Departamento de Caldas (Viejo Caldas) en 1905, conformado mediante la segregación de provincias del norte del Cauca y del sur de Antioquia, a las que luego se anexaron el Quindío y porciones de Tolima y Chocó. 


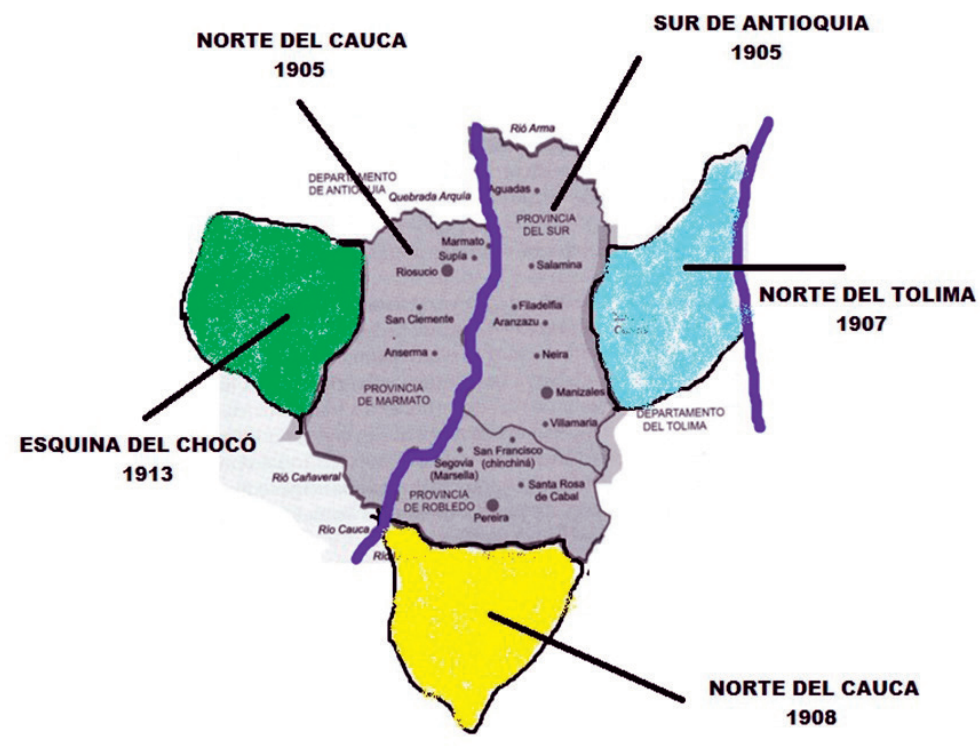

Mapa del ensamble del Departamento de Caldas

La Guerra de los Mil Días (1899-1901) y la separación de Panamá (1903) demostraron que si bien la Constitución de 1886 había logrado centralizar el país, no había detenido la saga de guerras civiles que había caracterizado al siglo XIX y por el contrario había afectado la integridad nacional. Reyes entendió que para lograr la paz duradera había que quitarle el agua al pez, es decir, eliminar las grandes entidades territoriales que fueron los Estados Soberanos (Cauca, Antioquia, Cartagena, Bolívar, Cundinamarca, Santander y Tolima), cuya inmensidad proveía de escenario, población y recursos a los caudillos regionales para iniciar y proseguir sus revoluciones. Con este objetivo fraccionó el país en más de treinta departamentos, uno de ellos el de Caldas, el que entraba a cumplir la función de poner una cuña entre las belicosas Antioquia y Cauca. Adicionalmente, la creación del nuevo departamento consolidaba la colonización antioqueña, dándole una base administrativa y política.

No fueron fáciles los consensos para armar la Mariposa Verde, o mapa del Viejo Caldas, como lo muestra la anécdota de su denominación. Los antioqueños quisieron llamarlo Departamento Córdoba por el general José María Córdoba, hijo de Santuario (Antioquia), pero los caucanos condicionaron la segregación de la Provincia de Marmato a que el nuevo departamento llevara el nombre del ilustre hijo de Popayán Francisco José de Caldas. Con su proverbial pragmatismo, los antioqueños cedieron en el nombre y se quedaron con el territorio.

En Riosucio, entonces capital de la Provincia de Marmato, no cayó bien la anexión al nuevo Departamento, porque, como se decía en una cita anterior, significaba plegarse a los antioqueños, sus eternos contrarios, y porque sus habitantes aspiraron 
hasta último momento a que le fuera otorgada la capitalidad a Riosucio en vez de a Manizales, como se dice que lo había concebido el general Rafael Uribe Uribe años atrás.

En la lógica de vencedores y vencidos, una vez creado el nuevo departamento, desde Manizales se impuso a rajatabla la identidad paisa para todo el nuevo ente territorial, invisibilizando sus componentes caucano, tolimense y chocoano. Con el tiempo, quedó la impresión de que Anserma, Guática, Quinchía, Riosucio y Marmato integraron Antioquia la Grande, cuando lo cierto es que dichos municipios nunca hicieron parte de Antioquia sino del Cauca.

Con los antioqueños en el poder la colonización sobre los resguardos indígenas careció de control desde el Departamento, excusado bajo los argumentos del progreso y del mestizaje. Diez años después de creado el Departamento de Caldas, otro viajero, esta vez antioqueño de Sonsón, el ya citado Rufino Gutiérrez, escribió que en su concepto la inmigración sobre los resguardos de Riosucio y municipios vecinos constituía una invasión civilizatoria que no afectaba los derechos de los indígenas:

Riosucio, julio 18 de 1917 (...) No hace muchos años que estas regiones estaban pobladas casi exclusivamente por indios que vegetaban en lastimoso abandono. Hoy, gracias a la invasión antioqueña, todas las tierras están cultivándose, y los antiguos pobladores en lugar de perder sus predios y convertirse en siervos mejoran de día en día y son hoy agricultores acomodados y ciudadanos que conocen sus derechos y gozan de ellos. El cruzamiento, el ejemplo y la nueva vida que llevan va mejorando la raza rápidamente ${ }^{97}$.

Pero una cosa percibió el hijo del poeta Gregorio Gutiérrez González y otra muy distinta la dirigencia nacional y regional. Después de los desastres de la Guerra de los Mil Días y de la separación de Panamá, la clase dirigente colombiana buscó compensar su fracaso con una modernización acelerada y una reapropiación territorial del país, que en el occidente, especialmente en el naciente Departamento de Caldas, tomó la forma de una campaña dirigida a dinamizar el mercado de tierras y a homogenizar como mestiza a toda la población, y ello significaba disolver la propiedad colectiva de los resguardos indígenas y desintegrar el componente indígena de la población.

En este sentido son más que elocuentes las palabras que Tomás O. Eastman (marmateño, ministro de Hacienda en 1910 y 1911) le dirigió a la Asamblea Republicana de Caldas en 1916:

En un siglo de constantes esfuerzos no ha logrado el Congreso resolver un problema sencillísimo, y ahí están todavía las parcialidades y sus resguardos, como ruinas de un edificio antiguo, inútiles hoy para todo el mundo y molestos

97 Rufino Gutiérrez, obra citada 
para la industria, el comercio y la agricultura. Fueron medios de civilización; la República los convirtió en simples estorbos ${ }^{98}$.

En Riosucio, Quinchía y Guática se documentan para la época muchos reclamos parecidos de parte de quienes apenas con treinta o cincuenta años de llegados a estos municipios pedían la disolución de las tierras indígenas.

\section{Escopetera Pirza se separa del Resguardo de La Montaña y elige Cabildo propio (1913)}

Poco se conoce de las dinámicas del territorio de Escopetera Pirza y de los terrenos ribereños del río Cauca a lo largo del siglo XIX, como tampoco de la situación de titulación del dominio, toda vez que no eran terrenos baldíos de la Nación sino mercedes de tierra entregadas a los españoles por la Corona, una parte de los cuales compraron los indígenas en 1759. A finales de ese siglo el territorio estaba siendo objeto de una doble colonización, por parte de familias de Riosucio (fundado en 1819) y de antioqueños (que están en auge colonizador), que "cogían" lo que abarcara la mirada o de un cerro a otro, comprando en algunos casos derechos reales o posesiones a los indígenas, quienes en ese entonces no tenían ni idea del valor de la tierra, y luego pasaban a formar parte de la masa de cosecheros que trabajaban bajo arriendo en las nuevas fincas, para, después de haber abierto los montes y haber recogido un par de cosechas, devolver las tierras arrendadas en aptitud de ser empleadas en agricultura o ganadería por el arrendador.

La Comunidad de Escopetera Pirza como propiedad privada colectiva, adquirida legalmente por los indígenas de La Montaña en 1759 y amparada en las normas del Código Civil, sufrió un duro revés en 1909 al disponerse desde los gobiernos municipal de Riosucio y departamental de Caldas la creación del Corregimiento de Bonafont, en memoria del padre José Bonifacio Bonafont, uno de los fundadores de Riosucio.

El cambio de nombre implicó de por sí invisibilizar la naturaleza ancestral y étnica del territorio, al ocultar los topónimos que recordaban el poblamiento ancestral Pirza y el más reciente apelativo de Escopetera. Aunque se mantuvo la figura del administrador de la comunidad, el territorio pasó a manejarse por las normas municipales generales de los corregimientos y las inspecciones de policía.

Preocupados por el ingreso de foráneos al territorio y por las ventas que hacían los comuneros de sus parcelas, en 1913 los indígenas tomaron la decisión de separarse del Resguardo de La Montaña, de someter los terrenos comunales de Escopetera Pirza a la legislación indígena y de conformar Cabildo propio. El nuevo Cabildo fue elegido el 13 de abril por una asamblea de 77 comuneros, celebrada ante el inspector

98 Citado en Luis Fernando González Escobar, Op cit., pág. 431. 
de policía, y al final del acta respectiva le piden a la Alcaldía y a la Notaría de Riosucio que hagan cumplir la Ley 89 y no inscriban aquellas ventas sin concepto previo del Cabildo.

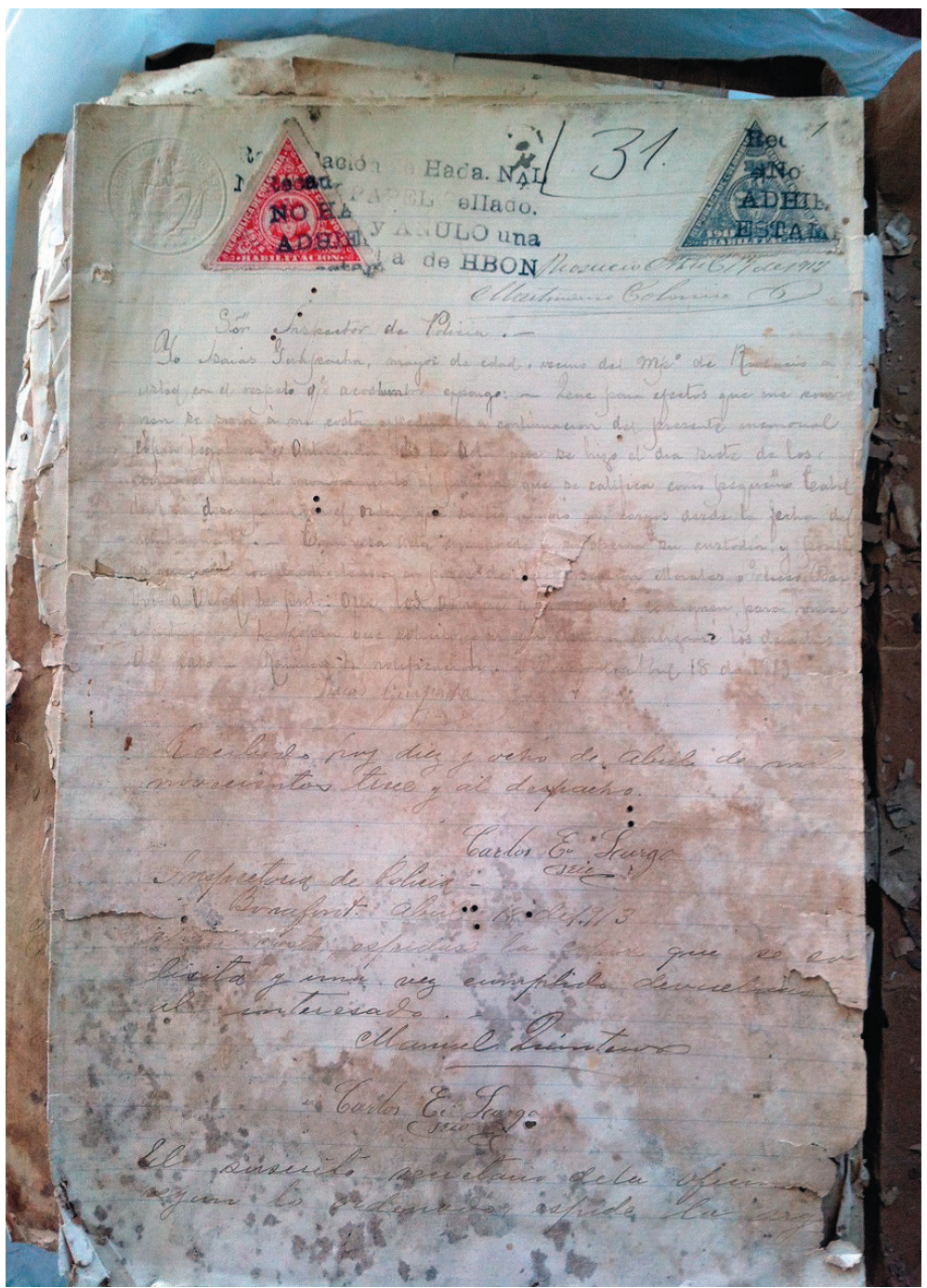

Acta de posesión del Cabildo de Escopetera Pirza en 1913. Archivo del Cabildo

En el corregimiento de Bonafont, a siete de abril de mil novecientos trece, en local adecuado, ante el señor Inspector de Policía de dicho corregimiento, se reunieron en común acuerdo todos los individuos partícipes del resguardo de Escopetera Pirza, hoy Bonafont, por sus antiguos linderos y cuyos terrenos al ser resguardo puramente de indígenas no está interrumpido por propiedad particular. Que el hecho de la presente reunión consiste en formar un Cabildo que separado de los demás resguardos [de] que hacían parte, hoy 
queda independizado, como lo dispone la ley en sus artículos procedentes sobre indígenas y en la forma como proveen [sic] sus resguardos con títulos legales debidamente registrados $=$ Procedióse pues al efecto, contando con la voluntad de todos sus miembros, que no excediendo de 77 individuos que a continuación firmarán, a la elección de Gobernador, Alcalde $1^{\circ}$, Alcalde $2^{\circ}$, Regidor $1^{\circ}$ y $2^{\circ}$, y tres miembros para componer el pequeño Cabildo; se hizo la elección así: Por el Gobernador, voto unánime, obtuvo la mayoría el señor ASCENSIÓN MORALES.- Por el Alcalde $1^{\circ}$, voto unánime, obtuvo la mayoría el señor VALERIO LARGO.- Por el Alcalde $2^{\circ}$, voto unánime, obtuvo la mayoría el señor PEDRO P. BUENO.- Regidor primero y segundo, voto unánime, obtuvieron la mayoría los señores MANUEL MORALES y JOSÉ ALBERTO LARGO.- Por los tres vocales miembros que vienen a componer el Consejo del Cabildo, voto unánime, obtuvieron la mayoría los señores MANACES [sic] BUENO, BONIFACIO LADINO y LUCIANO GUAPACHA.-----Acto continuo, obtenida la mayoría, y habiendo salido electos los señores indicados N N N N N, se dispuso que en presencia del señor Inspector de Policía, a quien le correspondió presenciar dicho acto, por ausencia del señor Alcalde Municipal, sean posesionados en dicho acto, para los efectos de la ley. Dispúsose además para terminar el presente acto que por conducto del señor Inspector de Policía se obtenga del señor Alcalde su aprobación o registro, como darle cuenta por nota oficial al señor Notario Público de Riosucio, para que se cumplan las disposiciones indicadas en la Ley 89 de 1890 y decretos en materia de Resguardos, como en relación a ventas [ilegible] que están en un todo prohibidas, acción que toca al Cabildo, según aviso del Notario Público desvirtuar toda acción pretendida a este respecto.- Como se da por terminado el presente acto firman enfrente los que intervinieron en ella con el señor Inspector de Policía y secretario. Manuel Quintero [Inspector de Policía]. Eliseo Bartolo [Secretario]. Sobra decir que ni el alcalde inscribió el Cabildo en el Libro de posesiones del Municipio ni el notario dejó de autorizar las ventas de cuotas pro-indiviso como si fueran propiedades plenas.

\section{Monografía de Riosucio en el Centenario}

Una ilustrativa descripción de la apariencia del Municipio de Riosucio para la época del Centenario de su fundación se encuentra en la monografía escrita por Rufino Gutiérrez en 1917 y publicada en 1921, la cual puede consultarse en la biblioteca virtual del Banco de la República (babel.banrepcultural.org/cdm/res/collection/ p17054coll10/id/2506) 

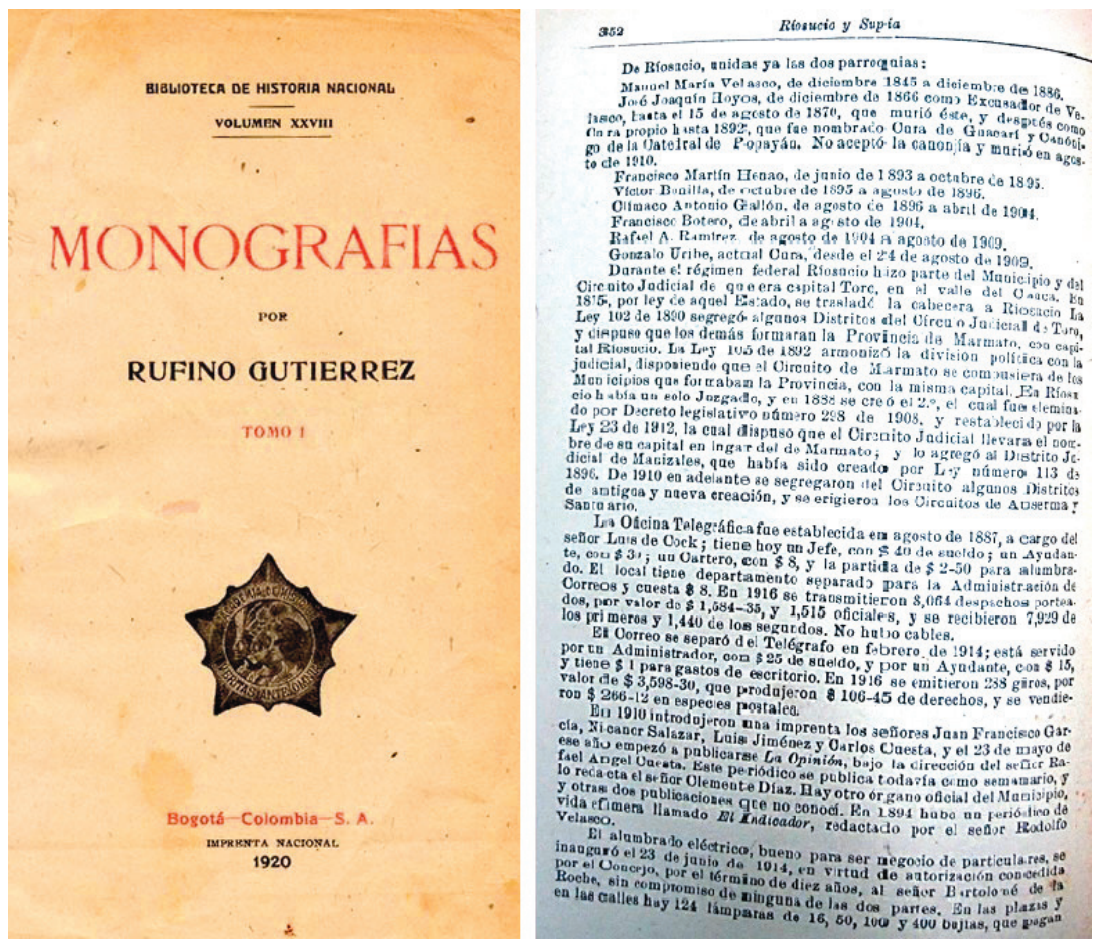

\section{El proyecto nacional para disolver los resguardos indígenas coloniales, empezando por los de Riosucio y en particular por San Lorenzo (1939-1943)}

Antes de cumplirse el plazo de cincuenta años concedido por la Ley 89 de 1890 para dividir los Resguardos indígenas provenientes de la época de la Colonia, la Ley 19 de 1927 ordenó disolver todos los resguardos indígenas del país. La medida legislativa fue iniciativa de Francisco José Chaux y Luis C. Iragorri, senadores por el Departamento del Cauca. La ponencia correspondió a la misma de un proyecto anterior presentado en 1924 por los senadores también caucanos Guillermo Valencia y Manuel Caicedo Arroyo.

En dicha ponencia, la pluma del maestro Valencia pintó con trazos vivos y gran fuerza expresiva la mentalidad que dio lugar a la expedición de la citada Ley 19, para la cual la propiedad privada "es biológica" y los indígenas son una "fuerza perdida", "un peligro latente a la tranquilidad social", "un lastre inoficioso en la economía nacional", "una raza indolente, rutinera y desprovista de toda iniciativa" y motivo de incomodidad para "los desdichados blancos"; mientras los resguardos constituyen "bastiones de resistencia contra la raza blanca". 
Argumentaba Valencia que:

Es urgente la asimilación de aquellos grupos, su inserción en nuestra vida orgánica. Es menester acabar con aquellas costumbres ancestrales que paralizan en ellos toda iniciativa, que los lleva a borrar en sus hijos las huellas de civilización que penosamente les imprimimos en las almas y cuerpos. Es menester transformar en colombianos aptos aquellos exponentes de inutilidad aborigen, que se consumen en la desidia, el rencor y el desaliento.

A renglón seguido, el notable escritor parnasiano y simbolista propone al Congreso emprender la cruzada por la abolición de los Resguardos Indígenas:

Para esto es indispensable ir con mano resuelta a la división delos resguardos que virtualmente anula el régimen privilegiado concedido a aquellos compatriotas por las leyes vigentes. Cuando aparezcan en condición de propietarios, tendrán por fuerza que abandonar el temor reverencial a sus caciques, y será más fácil, extinguidos sus privilegios actuales, educarlos y civilizarlos. Hay que traerlos a convivir en los cuarteles, al lado de nuestros soldados y en el mismo pie de igualdad de éstos, y hacerlos partícipes de algunas funciones de la vida civil bajo el gobierno de autoridades comunes (...) Esta obra de liberación ofrece un doble aspecto: el de provecho para los indígenas, víctimas involuntarias de un régimen sedicente protector, y de emancipación para los desdichados blancos que han tenido la desventura y mal acierto de levantar vivienda, cerca de tan agresivos y desapacibles propietarios.

Finalmente el maestro abandona el simbolismo poético y revela que no es tanto la intención redentora de la raza indígena, sino un interés concreto económico lo que motiva el proyecto de ley. Abolidos los Resguardos, concluye el poeta legislador,

la República se sorprenderá cuando sepa de qué es dueña en las mejores tierras del macizo andino, sobre todo en la Cordillera Central. Minas de oro, fuentes saladas, caleras, bosques preciosísimos, mantenidos hoy bajo siete llaves por quienes son incapaces de beneficiarlos, se abrirán francos a la competencia nacional ${ }^{99}$.

La ejecución de la Ley 19 de 1927, expedida en las postrimerías de la Regeneración conservadora, le correspondió a la República Liberal, como un complemento de la Ley de Tierras (Ley 200 de 1936).

99 A.N.C. Poblaciones del Cauca, tomo 2, f. 1011, citado en: Presidencia de la República. Fuero Indígena Colombiano. Bogotá, 1990. Roque Roldán Ortega, compilador, págs. 84-86. 


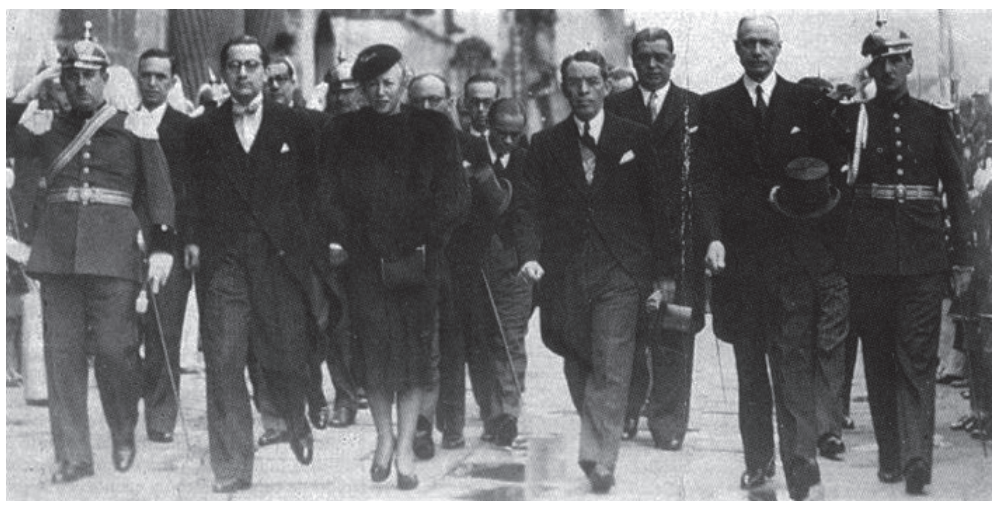

Posesión del presidente Eduardo Santos Montejo, 1938

El gobierno del presidente Eduardo Santos (1938-1942) emprendió la ejecución de la Ley 19, a través del Ministerio de la Economía Nacional, entonces a cargo de Jorge Gartner de la Cuesta, riosuceño con ancestro en los alemanes que llegaron al país a trabajar minería en Marmato. En su memoria al Congreso de 1939 el ministro dejó claro que para los personeros del Estado los indígenas ya no eran pueblos sino meros explotadores individuales de la tierra y sus Resguardos habían dejado de ser "las tierras que cuestionan como único patrimonio, como el solo bien que les legó la tiranía de los conquistadores" (palabras del personero de Supía en 1836), quedando reducidos a la categoría de bienes económicos, mercancías objeto del cambalache propio del siglo XX:

Resguardos de indígenas. Esta institución derivada de la Colonia y mantenida con escasas modificaciones por la República, presenta en el estado actual del país serios inconvenientes a su desarrollo agrícola; la división de grandes resguardos donde los indígenas han adquirido capacidad para el manejo y explotación de la tierra, es en concepto del Gobierno una medida de carácter trascendental que sacará del estancamiento económico grandes regiones propias para la agricultura y colocadas hoy fuera del comercio, desprovistas del uso del crédito, a causa de la comunidad (...) El problema es principalmente grave en Cauca y Nariño donde existen 53 y 89 resguardos, pero también se presenta aunque menos agudo en otras secciones. En el Departamento de Caldas hay regiones de plena vida civilizada aún sometidas a este régimen y detenidas en su progreso ${ }^{100}$.

Como se anuncia en la última parte del mensaje, el proyecto liquidacionista habría de comenzar por los Resguardos de Caldas, y en efecto el Resguardo de San Lorenzo, en Riosucio, fue tomado como plan piloto para la medida que se extendería a todo el país. 
El expediente del Ministerio de la Economía Nacional 1939-1943, que se conserva en el Archivo General de la Nación (169 páginas), permite reconstruir la manera como se dio el proceso de disolución en el Municipio de Riosucio. La narración y las citas textuales que siguen corresponden a este expediente.

\begin{tabular}{|c|c|c|}
\hline $\begin{array}{l}\text { ARCHIVO } \\
\text { GENERAL } \\
\text { DE LA NACIÓN } \\
\text { COLOMBIA }\end{array}$ & $\begin{array}{l}\text { Contiene documentos relacionados con el } \\
\text { proceso jurídico que siguió el resguardo indígena } \\
\text { de San Lorenzo, municipio de Riosucio (Caldas), } \\
\text { para que sus terrenos no fueran entregados a } \\
\text { los habitantes del resguardo según lo ordena el } \\
\text { decreto } 2454 \text { de } 1939 \text {, por el cual se decide la } \\
\text { división del resguardo de manera proporcional } \\
\text { al número de habitantes, sino que se proceda a la } \\
\text { titulación de terrenos según las adjudicaciones } \\
\text { que el cabildo había realizado con anterioridad. } \\
\text { Entre la documentación hay un estudio jurídico } \\
\text { que describe los problemas de titulación que } \\
\text { se presentan en los resguardos de San Lorenzo } \\
\text { en el departamento de Caldas, y Silvia en el } \\
\text { departamento del Cauca. }\end{array}$ & $\begin{array}{l}\text { CO.AGN. } \\
\text { SR.60A.30.12.2.1 / } \\
\text { [Resguardo de San } \\
\text { Lorenzo, Municipio } \\
\text { de Riosucio, Caldas. } \\
\text { Planos del resguardo } \\
\text { y trascripción de } \\
\text { documentos del año } \\
\text { 1935] (1939 / 1943). } \\
\text { Folios 1-169 } \\
\text { Signatura de } \\
\text { procedencia } \\
\text { Caja antigua 265, } \\
\text { Carpeta antigua 2519 } \\
\text { (AGN7) } \\
\text { Escaneada en lo } \\
\text { referente a Caldas }\end{array}$ \\
\hline
\end{tabular}

Por resolución 421 de 3 de agosto de 1939 el ministro de la Economía Nacional comisionó al abogado Adolfo Romero B. para que "levantara las documentaciones de los resguardos ubicados en el occidente del departamento de Caldas", con el objeto de "acometer la división de los resguardos de indígenas del Departamento de Caldas, especialmente de los municipios de Quinchía, Guática, Riosucio, Mistrató y Supía”.

Para el caso de Riosucio, el abogado recogió la siguiente información:

El alcalde municipal estuvo de acuerdo porque los indígenas ya se habían civilizado; la privatización de los resguardos aumentaría la riqueza pública, y se acabarían los pleitos de los indígenas con los nuevos propietarios:

Conceptúo y considero provechoso y conveniente para los intereses de este Municipio, que las parcialidades indígenas que funcionan dentro de él, se liquiden mediante la división de los respectivos terrenos de resguardo de las mismas, pues la [ilegible] liberación de la propiedad que tal hecho traerá como inmediata consecuencia, aumentará la riqueza pública, y al terminar el estado de inseguridad motivado por los constantes pleitos ocasionados por la indivisión, los propietarios podrán dedicarse al establecimiento y fomento de empresas de alguna consideración sin el temor de ser lesionados en sus derechos ni de que sean obstaculizadas sus labores ${ }^{101}$. 
El Concejo Municipal opinó que los Resguardos eran del Municipio, según la Ley 55 de 1905, y por tanto era éste y no la Nación quien debiera repartirlos (J. Eduardo Orozco Ochoa, presidente del Concejo, $1^{\circ}$ de septiembre de 1939).

Los Cabildos de La Montaña y de Cañamono no aceptaron la división porque la ley no resolvía el tema de los colonos.

El Cabildo de San Lorenzo, con menos presencia de foráneos, aceptó la división, pero pidiendo que el reparto no se hiciera por medida sino por las parcelas que cada indígena tuviera adjudicadas.

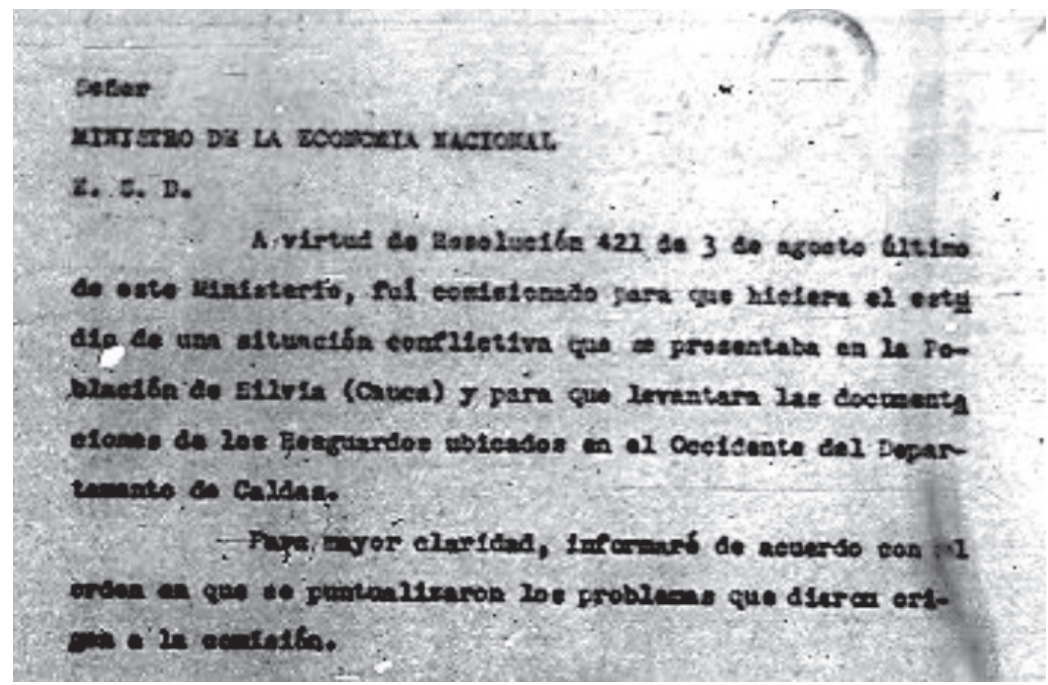

Facsímil del encabezamiento del informe del abogado Romero. AGN Bogotá.

Después de consultar a los alcaldes y personeros de todos los municipios del Viejo Caldas, así como a los Cabildos indígenas, Romero rindió su informe en Bogotá el 29 de septiembre de 1939, llegando a las siguientes conclusiones:

a) Se impone la división de los Resguardos del Occidente del Departamento de Caldas, a saber: 'San Antonio del Chamí' en Mistrató; 'Santana' en Guática; 'Quinchía' en el Municipio del mismo nombre; 'San Lorenzo', 'La Montaña' y 'Cañamomo y Lomaprieta' en Riosucio.

b) Debe principiarse por el resguardo de 'San Lorenzo', ubicado en Riosucio, por estas razones: Porque su división la reclaman los parcelistas; porque es el que menos tiene problemas pendientes; porque el Municipio citado es el que más necesita esa medida, dada su importancia; y porque la división de este resguardo puede encauzar la de 'Cañamomo' y 'La Montaña', que fueron de concepto adverso. 
c) Posteriormente puede decretarse la división del de 'Quinchía', no sólo por las razones que se dieron para la parcelación del de 'San Lorenzo' sino para liquidar las desavenencias que existen en la actualidad entre la Alcaldía de ese lugar y el Cabildo de la Parcialidad.

En su informe, el abogado no olvidó advertir al Ministerio sobre la situación irregular de los colonos al interior de los Resguardos:

Muchos indígenas enajenaron y enajenan sus parcelas sin llenar los requisitos del artículo 40 citado [de la Ley 89 de 1890 sobre pedir autorización judicial para las ventas]. Esas ventas, como lo dispone el inciso $2^{\circ}$ del mismo artículo, son nulas y de ningún valor y no pueden sanearse por el trascurso del tiempo (...) [Otro es el caso de particulares que] "han ocupado de hecho terrenos de los Resguardos. En esas posesiones han sido tolerados por los parcialistas y ellas se operaron desde hace muchos años: 10, 20 y 30 años. Actualmente tienen mejoras de valor apreciable. Siendo así que no pueden alegar prescripción, por las razones antes expuestas, ¿cómo quedarían estos poseedores al llevarse a cabo la división?

Con base en este informe, el Ministerio de la Economía Nacional expidió el Decreto 2454 de 1939 (Diciembre 27), "Por el cual se provee lo conducente a la división del Resguardo de Indígenas de San Lorenzo, en el municipio de Riosucio, del Departamento de Caldas".

Sin embargo, para el gobierno Santos la Ley 89 de 1890 y la Ley 19 de 1927 constituían un marco legal insuficiente para resolver la cuestión de los resguardos, por lo que, en un claro abuso de poder, hizo uso de las facultades extraordinarias que le concedió la Ley 54 de 1939 para conjurar los efectos de la II Guerra Mundial, para expedir el Decreto-Ley 1421 de 1940, "por el cual se toman algunas medidas tendientes a facilitar la división de los Resguardos Indígenas". El decreto, que lleva también la firma de Jorge Gartner, quien había pasado de la cartera de Economía a la de Gobierno, autorizó al Ministerio de la Economía Nacional a declarar inexistentes los resguardos, hasta que un juez no decidiera lo contrario:

Artículo 14. El Ministerio de Economía Nacional, declarará, previo el correspondiente estudio, si un Resguardo existe o ha dejado de existir, de acuerdo con las leyes que rigen estas instituciones. La respectiva providencia administrativa tendrá fuerza obligatoria mientras no sea rectificada por medio de sentencia judicial ejecutoriada.

Para comienzos de 1942 la disolución del Resguardo de San Lorenzo no había podido concluir debido a las dificultades prácticas para su implementación en la forma prevista en la Ley 89 . Se buscaron varias salidas jurídicas. Incluso hubo un proyecto 
de ley para el caso específico de San Lorenzo ${ }^{102}$. En la demora hasta se llegó a extraviar el expediente en las oficinas del Ministerio.

Un nuevo jefe de la Sección de Tierras del Ministerio de la Economía Nacional, Honorio Pérez Salazar, se empeñó en llevar el proceso a su fin, para lo cual le pidió una copia del expediente al ingeniero Gabriel Llanos G., miembro de la comisión divisoria de Resguardo de San Lorenzo y luego personero municipal de Riosucio, quien más se demoró en recibir la solicitud que en contestarla:

En este momento 6 de la tarde [del 13 de febrero de 1942] recibo su atenta comunicación $\mathrm{N}^{\circ} 1206$ y no obstante mis múltiples ocupaciones, con mucho gusto le doy los datos que me pide, pues estoy convencido de que los Resguardos son la rémora para el adelanto de los Municipios [...]

El trabajo es difícil, duro y peligroso, pues la disparidad de posesiones por parte de los indígenas, unido a las picardías que los tinterillos de ellos saben hacer desde hace años, entraban la cosa en grado máximo, pero el Gobierno está en el imperativo de dar fin a tales situaciones en cualquier forma sea legal o arbitraria (subrayas fuera del original).

El Gobierno optó por la arbitrariedad: Si San Lorenzo no se podía disolver como resguardo, había que quitarle la calidad de tal, declarándolo inexistente y, en consecuencia, baldías esas tierras. La Resolución $\mathrm{N}^{\circ} 01$ del 20 de mayo de 1943 del Ministerio de la Economía Nacional, firmada por el ministro Santiago Rivas, ya en el segundo gobierno de López Pumarejo, dispuso:

Declarar que el llamado Resguardo de San Lorenzo, situado en el Municipio de Riosucio, Departamento de Caldas, y cuyos linderos se transcriben a continuación, carece de la titulación necesaria para tener tal calidad y que, en consecuencia, sus terrenos no han salido del patrimonio del Estado.

Para el Ministerio, el defecto jurídico consistió en que el título de 1836 que exhibió la comunidad (pruebas de testigos ante el Juez de Supía y diligencia de posesión por el mismo juez) no era el original expedido por Lesmes de Espinosa y solo probaba la posesión pero no la propiedad sobre el supuesto resguardo. Esto a pesar que el propio Hombre de las Leyes le había reconocido valide $z^{103}$. La realidad era que para

102 Proyecto de ley "Por la cual se dictan disposiciones especiales que faciliten la división del resguardo de la Parcialidad de Indígenas de 'San Lorenzo' del Municipio de Riosucio del Departamento de Caldas”, presentado a la Cámara de Representantes y publicado en Anales del Congreso del 22 de agosto de 1942.

103 Los argumentos de la resolución fueron: "La simple diligencia de entrega, cuyo texto se transcribió atrás, no es prueba alguna de propiedad, pues no se hizo con ocasión de un juicio contradictorio de dominio, sino en virtud de una simple querella de policía con base en una perturbación de la posesión de la parcialidad de San Lorenzo por parte de otras parcialidades vecinas. Es decir, fue un simple reconocimiento de posesión carente de todo alcance dominical". Desconoció el Ministerio que en el Derecho Español (ni siquiera en el de Indias) la forma de perfeccionar la propiedad sobre un terreno era la diligencia de "posesión real, actual, corporal vel cuasi" de la cual se habló atrás, y esa ceremonia fue la que efectuó el Juez de Supía el 18 de marzo de 1836 en San Lorenzo. 
el Gobierno, después de cuatro años de demora en un proyecto de gran interés para el notablato nacional, la única forma de dividir el Resguardo de San Lorenzo era debilitando la posición jurídica de la comunidad, y así quedó expresado en los considerandos de la resolución:

Por eso, puede decirse que para las parcialidades que, como la de San Lorenzo, anhelan la división, es más favorable la carencia de sólidas titulaciones, porque (...) la división de las parcialidades sin títulos ciertos, se opera automáticamente con la declaratoria de inexistencia.

La Resolución del 20 de mayo de 1943 fue manifiestamente inconstitucional, no sólo porque vulneró el derecho de propiedad de la parcialidad, conseguido conforme a las leyes de la época, sino porque se basó en facultades otorgadas para conjurar los efectos de la II Guerra Mundial, conflicto en que nada tenían que ver los Resguardos indígenas.

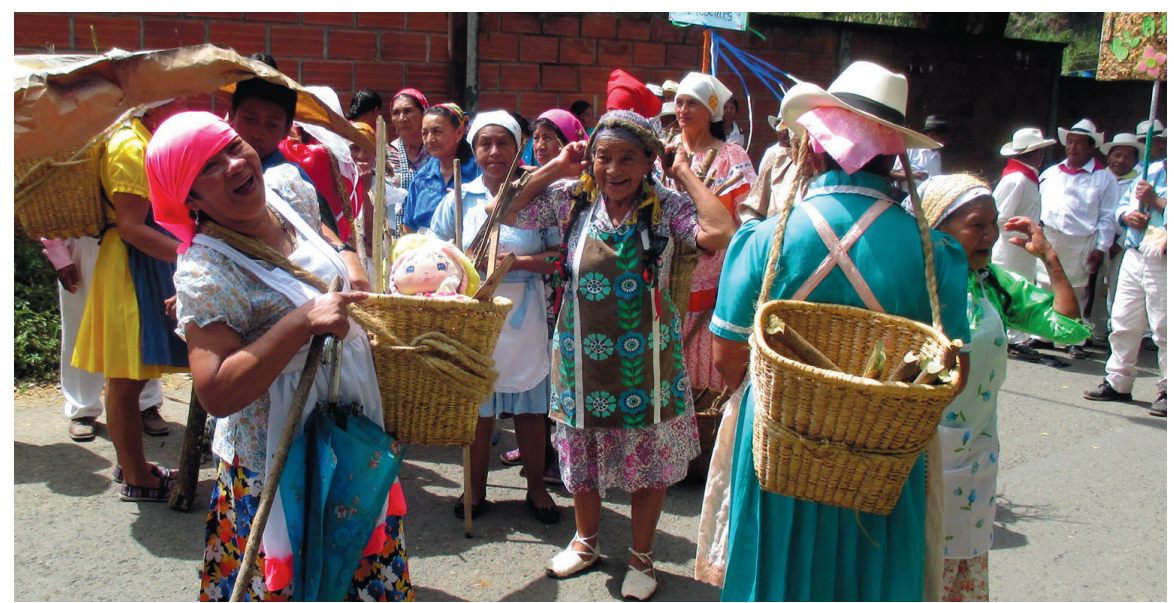

Fiestas de San Lorenzo, agosto de 2015

Además de repartir las tierras del resguardo como si fueran un baldío de la Nación, metiéndolas al mercado, la Resolución del Ministerio tuvo otros dos efectos: De un lado, inexistente el resguardo, cesaron también las funciones del Cabildo de San Lorenzo, creando un vacío que desde 1962 llenaron las Juntas de Acción Comunal. De otra parte, si no había Resguardo, entonces se saneaba la nulidad que afectaba las ventas hechas por los indígenas, con lo que se resolvió el tema de los colonos a favor de éstos.

Un caso concreto ilustra esta gabela contingente. El 14 de marzo de 1943, dos meses antes de la resolución de inexistencia, el gobernador de San Lorenzo acudió al Ministerio en busca de protección para el Resguardo frente a los colonos y a los propios indígenas que vendían sus parcelas, invocando al respecto la Ley 89 de 1890: 
me permito de la manera muy respetuosa y comedida solicitar del Señor Ministro, si el Cabildo de esta mencionada Parcialidad, de conformidad con la Ley 89 de 1890, puede adjudicar terrenos que están dentro de sus resguardos que han sido quitados injustamente por acaudalados y poderosos extraños que no son indígenas y que no están con cultivos o mejorados ni con condición especial de escrituras, como sucede con el señor Santiago González que ha quitado muchas adjudicaciones empleando la usura, a muchos indígenas adjudicados, dejándolos casi desamparados sin donde trabajar. También me veo en el caso de preciso de comunicarle o informarle a Ud. que varios indígenas no están contentos con la división de los terrenos de esta parcialidad, tales indígenas son aconsejados malamente por ambiciosos de los terrenos que no son indígenas (es decir, consejos de extraños ambiciosos) y los varios y [ilegible] indígenas de esta Parcialidad se han dado en la tarea de vender lotes de tierra que hacen parte de las adjudicaciones, vendiéndolas a menos precio a esos ambiciosos extraños.

El Ministerio respondió, mediante un memorando, que como el Resguardo no existía, no valía la pena demandar al señor González porque saldrían perdiendo los indígenas, y que al no existir resguardos, no se aplicaba la Ley 89 y por tanto las ventas que hicieran los indígenas no eran nulas:

No siendo suficientes los títulos que el resguardo alega para su existencia, no podría invocar la Ley 89 citada para reivindicar esos terrenos, y sólo haría con eso entrar en gastos a la comunidad, sin probabilidades de éxito, como ya le ha ocurrido. Tampoco beneficiaría a los presuntos adjudicatarios indígenas, a quienes colocaría en trance de seguros litigios sin el consiguiente beneficio que para ellos debe traer la correspondiente adjudicación que les haga el Cabildo. Por lo tanto, debe abstenerse de adjudicar esos terrenos.

En cuanto a las ventas que dice el Cabildo que están llevando a cabo algunos indígenas, de terrenos adjudicados en su calidad de parcialistas, se observa: No teniendo existencia legal el resguardo las ventas que los indígenas hagan de sus parcelas no deben reputarse como nulas a la luz de la Ley 89 de 1890. En este caso, sólo valdrían como enajenaciones de mejoras en terrenos baldíos.

Cuarenta años después de abolido el Resguardo de San Lorenzo, Honorio Pérez Salazar, mencionado ex jefe de la Sección de Baldíos del Ministerio de la Economía Nacional en 1943, reveló la forma como operaban las ventas subrepticias al interior de los Resguardos de Riosucio: los indígenas tenían que vender a precios irrisorios porque el comprador asumía el riesgo de la nulidad del negocio. Pero para el Gobierno el problema no era el despojo de la tierra que sufrían los indígenas, sino la desdichada situación de los compradores por culpa de la Ley 89 de 1890 que impedía la circulación de la propiedad: 
Hablamos de nuestra experiencia personal al respecto, y al decirlo queremos aludir concretamente a la disolución del resguardo de 'San Lorenzo', en el Municipio de Riosucio, Caldas, disolución ordenada por la Resolución del Ministerio de Economía Nacional Número 1 de 20 de mayo de 1943 (...)

Raro es el [indígena] que ha vendido su parcela y el que lo ha hecho ha sido porque se ha visto obligado a ello por alguna necesidad apremiante, o porque ha querido libertarse del régimen de oprobioso, pues es otra singularidad del curioso e injurídico estatuto [la Ley 89 de 1890] (...) un estatuto arcaico, imperfecto, altamente deficiente, que solo crea trabas, vallas y dificultades, manteniendo absolutamente paralizadas las relaciones jurídicas de los infelices parias que se debaten dentro de ese cepo aberrante y que han hecho de ellos seres sin dignidad, sin nociones de su valor humano (...)

Y es que en nuestro sentir, la causa de las ventas subrepticias en los resguardos, no ha sido otra cosa, aunque parezca paradójico, sino la misma restricción a las mismas ventas. Aún más: La causa de que estas ventas hayan sido hechas a precios irrisorios que han dejado la impresión de que el indígena ha sido engañado por el blanco, y que se exhiba a aquel como incapaz de manejar sus bienes, no ha sido otra que lo aleatorio del derecho que impide su libre circulación y retrae toda demanda, ya que el comprador queda sometido al riesgo de la nulidad, y naturalmente ha de compensarlo con un precio menor 104.

La solución de inexistencia adoptada para el Resguardo de San Lorenzo, como caso piloto que era, se replicó en el resto del país. Así lo informó el ministro de la Economía Nacional al Congreso en 1946:

Resguardos de indígenas. Desde cuando se inició por este Despacho la sana política de la disolución y división de estas arcaicas instituciones, cuya subsistencia es un peso muerto para la economía de ciertos Departamentos, como los de Cauca y Nariño, en los que su número es muy grande, varios de estos resguardos han sido ya disueltos, y algunos totalmente divididos mediante la adjudicación de las parcelas ocupadas por los indígenas integrantes de cada uno de ellos, como el de San Lorenzo, en el Departamento de Caldas. Los resguardos declarados disueltos hasta hoy, además del antes indicado, son: Tangua, Catambuco y Pandiaco, en Nariño; Turminá, Tálaga y Guanacas, en el Cauca ${ }^{105}$.

104 Honorio Pérez Salazar, "Emancipación del indígena de resguardo", en: Gustavo Ardila Urueña, La problemática indígena en Colombia Katío, Pereira, Fondo Editorial de la Gobernación de Risaralda, 1984.

105 José Luis López. Memoria del Ministro de la Economía Nacional al Congreso de 1946. Tomo I. Bogotá, Imprenta Nacional, pág. 122. 
Con posterioridad a 1943 se registraron las siguientes disoluciones de Resguardos en el Departamento del Cauca ${ }^{106}$ : Yanaconas, Pueblillo, Julunito, Puelenje, Calibío y Santa Bárbara (Popayán); Los Achintes, Pandiguando, Piagua y Chapa (El Tambo); San Sebastián (Santiago), y Tunía (Tunía).

\section{La posición de los Cabildos de Riosucio frente a la disolución}

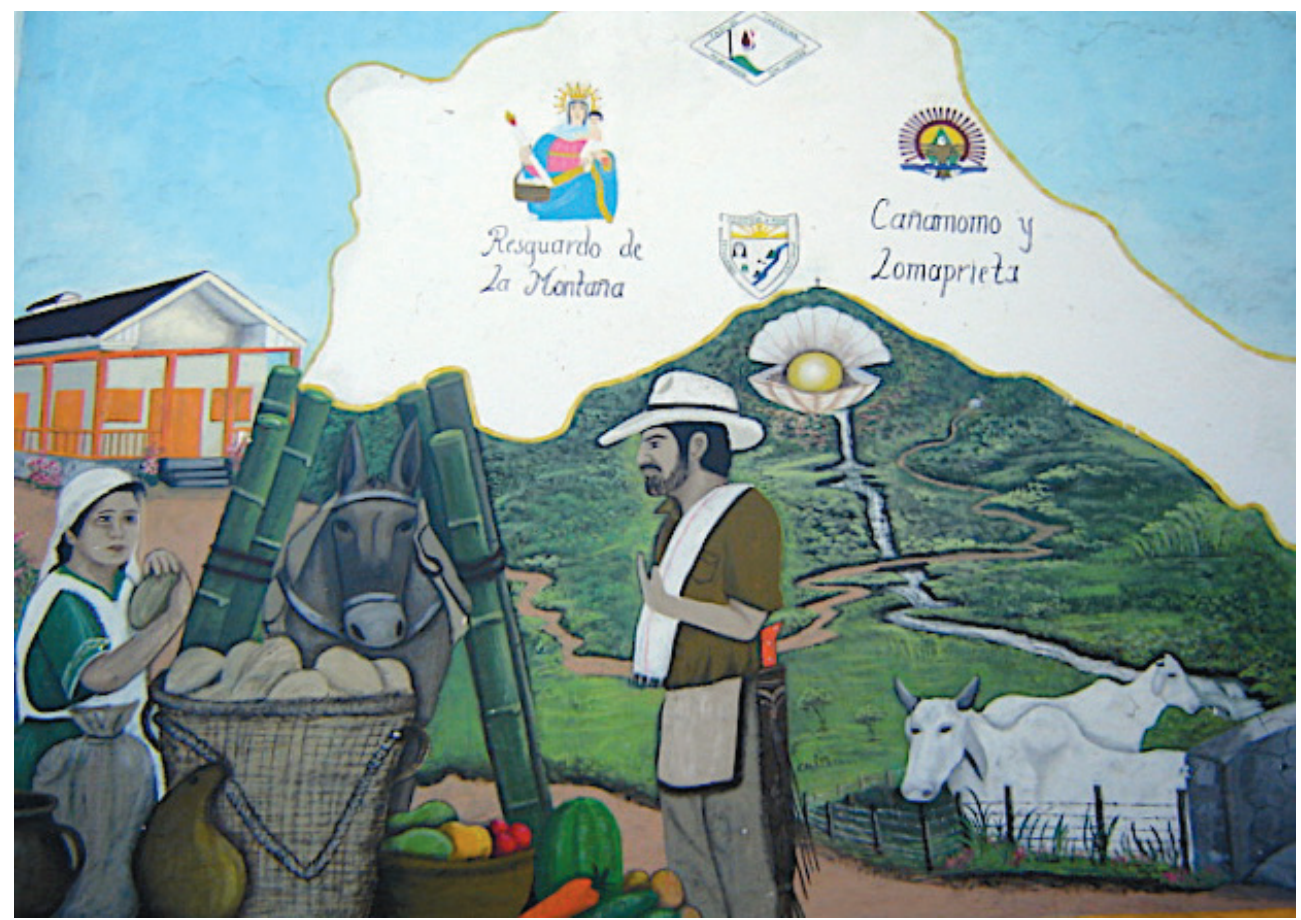

Mural en la Galería de Mercado de Riosucio

Los Resguardos de Riosucio no tomaron una posición unificada. Cada Cabildo fue entrevistado por separado por el abogado del Ministerio. La fuente del siguiente relato son los documentos conservados en el Archivo General de la Nación y catalogados como quedó dicho atrás.

\section{San Lorenzo}

En 1939 el Cabildo de San Lorenzo aceptó entrar en el proceso de división del Decreto 2454 de 1939 (Dic. 27), con condiciones.

A comienzos de enero de 1940, en carta al ministro Jorge Gartner, el Cabildo expresó: "la parcialidad contempla con regocijo la hora llegada de su extinción". Pero el 27 de ese mes Isidro Gañán, gobernador, con la firma del Cabildo en pleno y las de 275

106 Luis Carlos Iragorri. Apuntes para un estudio económico y fiscal del Cauca. Popayán, 1962, pág. 59. El autor agrega que estaban en turno de disolución 46 parcialidades, antes que en 1958 se suspendiera esta política. 
comuneros, rechazan que se haga la partición por el Decreto 2454, el que consideran que "lesiona gravemente nuestros intereses y los del Municipio a que pertenecemos" y piden que se derogue.

El 21 de julio de 1941 el Cabildo protesta porque Gabriel Llanos, ingeniero de la Comisión Divisoria, "nos informó también verbalmente que los bosques (o montañas como nosotros los nombramos) no serán repartidos porque ellos dizque se los reserva la Nación", exigiendo "que cada familia reciba lo que legalmente le corresponde teniendo en cuenta toda la extensión territorial de la parcialidad demarcada por los linderos que constan en su título de propiedad"

El 8 de junio de 1942 le piden al Ministerio: 1) Que la división no se haga por medida sino de hecho, dejando a cada indígena en dominio y posesión de lo que tiene; 2) "Que se reconozca a los particulares también el dominio y posesión de sus inmuebles pero únicamente a los que presenten títulos bien legalizados y que paguen el valor del terreno"; 3) "Que los terrenos adquiridos de mala fe pasen al dominio de la parcialidad para adjudicarlos a sus miembros que no lo hayan sido", y 4) Que los dineros que se recauden sean para pagar deudas de la administración de la parcialidad, el fomento de la agricultura y el arreglo de los establecimientos de educación. Firman, además del Cabildo en pleno, 478 indígenas.

Pasó todo el año de 1942 y la disolución del Resguardo de San Lorenzo seguía sin resolver, por lo que el 3 de febrero siguiente un nuevo ministro de la Economía Nacional, Santiago Rivas, envió a Riosucio al abogado Rey Zúñiga con amplios poderes para acceder a las peticiones de la parcialidad, con base en una nueva teoría jurídica: que el Resguardo no existía y por tanto la división de las tierras podía hacerse sin sujeción a la Ley 89.

Luego de entrevistarse en el casco urbano con el ingeniero Gabriel Llanos, ahora Personero Municipal, el abogado se desplazó a San Lorenzo el $1^{\circ}$ de marzo, "siendo como era día lunes, día de lo que ellos llaman 'el mandado", donde habría de celebrarse la última reunión de lo que hoy se llamaría de "consulta previa" y "protocolización" de la misma.

A su regreso a Bogotá, el abogado le informó detalladamente al ministro cómo hizo para convencer a los indios de San Lorenzo para aceptar la división del Resguardo. El informe tiene fecha del 29 de marzo de 1943 y es prolijo en narrar los detalles de la reunión, que se resumen como sigue:

1) Que practicó visitas a San Lorenzo, Riosucio y Manizales; 2) Que con quien primero se contactó fue con el ingeniero Gabriel Llanos G., Personero Municipal, por quien percibió que "la situación en un principio presentaba caracteres difíciles y sombríos debido a la resistencia que los indígenas ofrecían a la disolución del resguardo y sus constantes manifestaciones de oponerse por todos los medios a la partición de la tierra, influidos ciertamente por corifeos 
políticos y espirituales del lugar"; 3) Que Llanos le facilitó copia de la carta que le había enviado el Cabildo al Concejo Municipal oponiéndose al reparto y la que él como personero envió al Procurador General; 4) Que en el pueblo quiso percibir la opinión general sobre la disolución entre las diversas clases sociales y políticas "y pude comprobar que la mayoría de esas clases, grupos o bandos era opuesta" y de ello provenía la oposición de la parcialidad; 5) Que varios jefes políticos locales se ofrecieron a acompañarlo para hacer fracasar el entendimiento entre el Cabildo y el comisionado del Gobierno, pero él declinó la oferta; como también declinó la del alcalde -Antonio J. Arango- de prestarle un piquete de policía, pues "cuando se trata más bien de persuadir que de imponer, toda medida que pueda interpretarse como amenaza o provocación suele ser inconducente"; 6) Que en las primeras reuniones con los indígenas unos le tenían repugnancia a la disolución y otros callaban pero se les notaba que tampoco estaban de acuerdo; 7) Que en el pueblo se entrevistó el domingo 28 de febrero con el inspector de policía y con el gobernador indígena; 8) Que el día siguiente bajó a San Lorenzo, "siendo como era día lunes, día de lo que ellos llaman 'el mandado", donde se reúnen grupos de indígenas a tratar asuntos comunes y tomar determinaciones, "las que generalmente terminan en zambras espantosas por la cantidad de guarapo (caballo) que toman", por lo que se apresuró a hacer la reunión antes que empezara la libación; 9) Que la reunión se llevó a cabo en la sede del Cabildo donde el gobernador, J. Francisco Betancur, manifestó que no estaban dispuestos a permitir la división porque "actualmente cada indígena tenía los medios para atender a sus necesidades propias y a las de su familia; más tarde, con la partición que pretendía llevar a cabo el Gobierno, muchos de los actuales poseedores serían desposeídos de sus tierras, y que los menores de 18 años, al salir de esa edad nada encontrarían porque ya el Gobierno lo habría adjudicado todo" y porque "estando también la parte inculta [la zona de bosques] dentro de los linderos del resguardo, el gobierno no les adjudicara esos terrenos a los que muchos indígenas habían ya vinculado su esfuerzo"; 10) Que "acto seguido (...) les hice ver que el resguardo no tenía existencia legal por carecer de un título jurídico, y por consiguiente la existencia del Cabildo y sus decisiones no podían encontrar acogida en el Gobierno si aquel se empeñaba en su política de saboteo a las medidas de éste"; 11) Que les explicó los beneficios de ser propietarios de sus parcelas para mejorar los cultivos y construir casas higiénicas "con préstamos de la Caja Agraria”; 12) Que les dijo que sus temores eran infundados, y sólo obedecían a insinuaciones malévolas de candidatos electorales; 13) "Que nadie podría sufrir perjuicio, ya que el Gobierno a nadie que tuviera derechos reconocidos pensaba despojarlo, y muy por el contrario, quería fortalecer los títulos ya creados y creárselos a quienes no los tuvieran"; 14) "Que el Gobierno pensaba declarar baldíos los terrenos pertenecientes al resguardo" para así adjudicarles como tierras baldías de menor cuantía a quienes estuvieran establecidos y 
tuvieran mejoras; 15) Que la parte inculta sería reservada por el Gobierno para ser adjudicada sólo a los indígenas, en especial a los menores cuando fueran mayores y tuvieran familia, eliminando así el fantasma de la mendicidad y la prostitución; 16) Que cuando tuvieran dudas se dirigieran al Gobierno y no a los políticos; 17) Que después de esta intervención hablaron los cabildantes Nemesio Gañán y Manuel Santos Tapasco, a quienes absolvió las inquietudes; 18) Que "cuando finalicé, el ambiente denotaba una radical transformación; todos se mostraban satisfechos con las medidas del Gobierno, y me advirtieron que su actitud se había debido al engaño en que los mantenían algunos interesados de la región", y 19) Que él solicitó que consignaran este acuerdo en un acta en tres copias, la que se redactó con el consentimiento del inspector de policía que estaba presente.

En efecto, al final de esa consulta se firmó la siguiente declaración:

Los suscritos miembros del Cabildo de la Parcialidad Indígenas SAN LORENZO, en el Municipio de Riosucio, dejamos expresa constancia que después de haber escuchado la exposición del Abogado-Comisionado del Ministerio de la Economía Nacional, doctor Emiliano Rey Zúñiga, declaramos que nuestras dudas y temores por los cuales nos oponíamos a la división de este Resguardo, han quedado absolutamente resueltas y hemos llegado al conocimiento que los indígenas no sufrirán perjuicios de ninguna clase. Por consiguiente manifestamos que estamos dispuestos a prestarle toda la cooperación y ayuda que nos sea posible al Gobierno Nacional para llevar a cabo tan pronto como las circunstancias lo permitan la partición del susodicho Resguardo. Así mismo manifestamos que las dudas de que arriba se habló consistían en el temor de que poseedores actuales de terrenos fueran hacer [sic] despojados de ellos; como también no fueran hacer [sic] adjudicados muchos lotes de terrenos situados en parte montañosa. Dado en San Lorenzo a 18 de marzo de 1943" [debe ser $1^{\circ}$ de marzo] (firman el Gobernador y los demás cabildantes, y acepta el abogado Rey Zúñiga).

Quince días después de esta reunión el gobernador de San Lorenzo, J. Francisco Betancur, le dirigió al ministro de la Economía la petición citada atrás del 14 de marzo en que le pedía aplicar la Ley 89 de 189 para proteger el Resguardo frente a los colonos que acaparaban las tierras y los indígenas que las vendían, lo cual indica o que el abogado Zúñiga no dijo lo que dice que le dijo al Cabildo, o que los indígenas no entendieron que el resguardo era inexistente ni que la Ley 89 de 1890 ya no se aplicaba.

En mayo de 1943 el Resguardo colonial de San Lorenzo fue declarado inexistente y dos décadas después el Gobierno cumplió el compromiso de no adjudicar la zona de bosques, procediendo a crear la Reserva Indígena de San Lorenzo mediante el Decreto 1130 de 1960 del Ministerio de la Agricultura. 


\section{Nuestra Señora Candelaria de la Montaña}

Respuesta del Cabildo de Nuestra Señora Candelaria de La Montaña a la petición de Adolfo Romero, abogado del Mineconomía. 15 de noviembre de 1939:

1) "El censo no ha podido censar todas las familias", por lo que no se puede dar un número exacto de familias ; 2) "Como ya se dijo, todo el resguardo en general se encuentra ocupado por personas extrañas que no pertenecen a la clase indígena, como también existen predios en reunión de indígenas y de particulares, pues el número de personas extrañas quizás pasan de 500 y con posesiones que pasan más de treinta años"; 3) "Así pues que el cabildo que representamos a la citada parcialidad de la Montaña, según la ocupación y posesiones de personas extrañas de bastante tiempo, y como la parcialidad ha sido muy pobre sin de donde proveer recursos necesarios para defender de las numerosas usurpaciones que se han hecho en el territorio. Hoy los indígenas que se encuentran un poco estrechos en su territorio con sus pocas labranzas, no aceptan la división del resguardo, por cuanto que los particulares sí se quedan muy frescos. El cabildo en representación de la parcialidad y como tales ratifican no se acepta la citada división por estar en intranquilidad el resguardo, pues por esos tropiezos no se puede aceptar su división".

En 1944 el Ministerio de la Economía Nacional insistió en la división del Resguardo de La Montaña, y en que el Cabildo enviara a Bogotá los informes del caso, pero el Cabildo se opuso de nuevo. El gobernador indígena, Juan Román Pescador le pide al ministro, en carta del 10 de abril, que le explique con qué fin quiere los informes solicitados; que si es con el fin de repartir el Resguardo, le recuerda que en 1939 ya se le había preguntado a la parcialidad si convenía con el reparto, y en una reunión de 500 jefes de familias manifestaron no aceptar la división, por lo que tampoco el Cabildo la aceptó, por lo cual ahora la comunidad insiste en no aceptar el reparto ni comprometer esos bienes. Dan como razón que cada cual tiene lo suyo.

No obstante lo anterior, en comunicación aparte del mismo día, 10 de abril de 1944, el Cabildo responde el cuestionario del Ministerio, así: Habitantes: 2.004 jefes de familia; 20 kilómetros de extensión, con muy poquito sin cultivar; idioma castellano; organización los miembros del Cabildo; en grado de cultura hay muchas personas entre 40 y 60 años que no saben leer y escribir porque en su tiempo no había quién enseñara, pero desde hace 30 años hay 7 escuelas para educar niños indígenas y particulares, de cuenta del Dpto. de Caldas, ubicadas en Pueblo Viejo, Santa Inés, Chancos, Las Estancias, La Florida, El Salado y Ubarbá (dan número de niños por cada escuela, que son 396 niños y 268 niñas para un total de 664 estudiantes); (ilegible lo referente a medios de vida, comercio y vías de comunicación); sin cultivar está la parte de Arroyohondo a La Línea, pero produce 100 cargas semanales de carbón de leña; enumera las aguas; tienen litigios de tierras con los Chamí y con San Lorenzo que se apropió de una porción muy grande por prescripción de 30 años, mientras la 
mitad del resguardo está ocupado por particulares, más los que viven en medio de los indígenas, que todos alegan que tienen documentos de compra a los indígenas.

En documento anexo el Cabildo identifica con los nombres los particulares que tienen fincas en medio de los indígenas en La Candelaria, El Salado, La Zulia y Chuscal, Santa Inés y Montaña Viejo, Pueblo Viejo, Ubarbá, Los Chancos, Travesías de Ubarbá, La Palma, La Florida, Cábarga, que en total suman 136 colonos. En otro anexo informa que las fracciones del Resguardo ocupadas solo por colonos son: Las Estancias, Las Partidas, La Robada y Las Carboneras, El Oro, Llano Grande, La Sirena, Cambía, Palermo, San Vicente, Palestina, El Rosario. Todos con posesiones de 50 años.

El mismo día, 10 de abril de 1944, el Cabildo se quejó ante la Procuraduría de que el Concejo Municipal les estaba cobrando impuesto predial.

Sólo hasta el 9 de agosto de ese año llegó a Riosucio la respuesta del Ministerio de la Economía Nacional a las inquietudes del Cabildo de La Montaña, en el sentido de aclarar que con el cuestionario enviado meses atrás

solo se persigue obtener la mayor cantidad de datos posible sobre cada resguardo, a fin de comprobar el grado de desarrollo económico y cultural de ellos, y ver si en un futuro próximo o lejano se puede aplicar la fórmula empleada por el Ministerio para disolución de las parcialidades, que tan benéficos resultados está dando.

En 1950 falleció el gobernador de La Montaña y la parcialidad se quedó sin Cabildo, por lo que en 1953 un grupo de indígenas le solicitó al Ministerio de Agricultura que extinguiera y parcelara el resguardo como se había hecho en San Lorenzo. Adujeron, entre otras cosas, que:

Individuos que se dicen representantes del Gobierno Nacional están explotando en la actualidad el campesinato mediante el cobro de crecidos emolumentos o contribuciones, dizque para parcelar, revisar títulos, declarar la validez o nulidad de éstos, sin que sepamos a ciencia cierta si efectivamente son los representantes del Gobierno a cuyo nombre dicen actuar.

El Cabildo de La Montaña volvió a funcionar en 1960 con Pedro Largo Pescador como gobernador, cargo que desempeñó hasta 1980. 


\section{Cañamomo Lomaprieta}

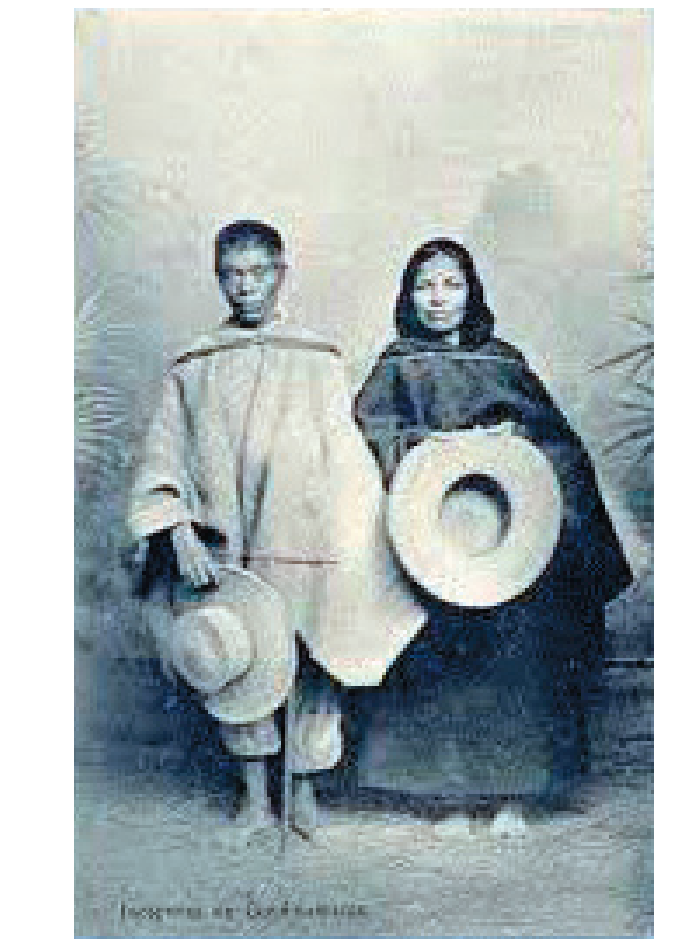

Pareja de Cañamomo Lomaprieta (foto de internet)

Extractos del informe del abogado Adolfo Romero del 29 de septiembre de 1939:

- El título de Cañamomo es la Escritura No 79 del 13 de febrero de 1936, donde consta que la posesión se la entregó el alcalde de Anserma el 4 de noviembre de 1722. "No obstante lo anterior, tengo conocimiento que el virrey José Solís Folch de Cardona en el año de 1757, les expidió un título de propiedad a los indígenas de esta parcialidad sobre unos terrenos situados a la margen izquierda del río Supía. Este título dizque fue acompañado al juicio de deslinde que sostuvo la parcialidad en el año de 1893 contra la señora Avelina de la Roche, y ante el Juzgado del Circuito de Marmato, residente por ese entonces en Riosucio". Los linderos son los que presenta la comunidad "excluyendo el terreno cogido por los usurpadores blancos". Censo hubo en 1874 o 1875. En 1939 hay 175 familias, con 1.400 personas.

- "La extensión primitiva del Resguardo fue de 4.500 hectáreas. Pero dentro de él funcionan las comunidades civiles de Sipirra, Quiebralomo, Tumba-Barreto y Guamal que suman una superficie de 3.060 hectáreas. De las 1.400 hectáreas restantes, 300 ocupa el resguardo y las demás la tienen cogidas los particulares (...) Entre ellos están Alejandro y 
Obdulio Toro y (ilegible). Las posesiones de estos se registran desde hace varios años".

- Hay muchos problemas de linderos con particulares.

- "El Cabildo de esta Parcialidad es adverso a la división del Resguardo, especialmente porque dizque la división 'no se puede acometer sin saber el resultado del reclamo judicial de los pleitos contra los usurpadores”.

- Los litigios que tiene la comunidad son: contra Alejandro y Obdulio Toro sobre la finca "El Peñol"; contra Vicente (ilegible) por la finca "La Rueda"; contra Vicente y Víctor de la Cuesta por las fincas (ilegible), y contra (ilegible) por la finca "Aguas Claras".

En 1944 una comisión del Ministerio de la Economía Nacional visitó la comunidad de Cañamomo. El informe del 13 de mayo del abogado Emiliano Rey Zúñiga dice que la visita les permitió conocer la situación de esos "supuestos indígenas", que en número de 1.000 a 1.200 viven en chozas diseminadas en el resguardo y algunos concentrados en Guamal y La Iberia, que

"se dedican principalmente a la holgazanería" y "no tienen ningún rasgo o característica aborigen (...) dan la impresión de estar más ante un zambo que ante un descendiente indígena" (...) "La desconfianza de estas gentes con las autoridades de todos los órdenes es inmensa" (...) "Se oponen rotundamente a que se disuelva el resguardo con la misma fórmula aplicada a San Lorenzo" (...) "Desean sí que el Gobierno Nacional compre o simplemente despoje los propietarios para que les entreguen esas tierras y poder así recuperar parte siquiera de lo que, según ellos, fue la parcialidad de indígenas de CAÑAMOMO Y LOMAPRIETA" (...) "Actualmente tienen ante el Tribunal Superior de Manizales tres litigios" (...) "Se quejan de los constantes atropellos de que son objeto por parte de los ricos y autoridades de Riosucio; en algunos casos, hasta tienen razón".

\section{El caso de Escopetera Pirza}

En 1939, durante la visita que Adolfo Romero, abogado del Ministerio de Economía Nacional, hiciera al corregimiento de Pirza y Bonafont, Benjamín Tabarquino y otros vecinos le entregaron algunos documentos relacionados con la propiedad de esos terrenos, consistentes en los que se citaron atrás relativos a la compra de los terrenos de Pirza en 1759 a la española Catalina Jiménez por parte de un grupo de indígenas de La Montaña, con la solicitud que les dijera si eran Resguardo o no y si entraban en el proceso de división.

El abogado Romero concluyó que estos documentos no constituyen un título de Resguardo indígena sino de comunidad civil (terreno en común bajo reglas del 
Código Civil), puesto que no fueron entregados por la Corona sino adquiridos mediante una compra entre particulares, y por tanto no entran en el proyecto de división de resguardos. Recomendó que para dividir esos terrenos los comuneros debían pedir la disolución de la comunidad civil ante el Juez de Tierras de Manizales (Ley 200 de 1936).

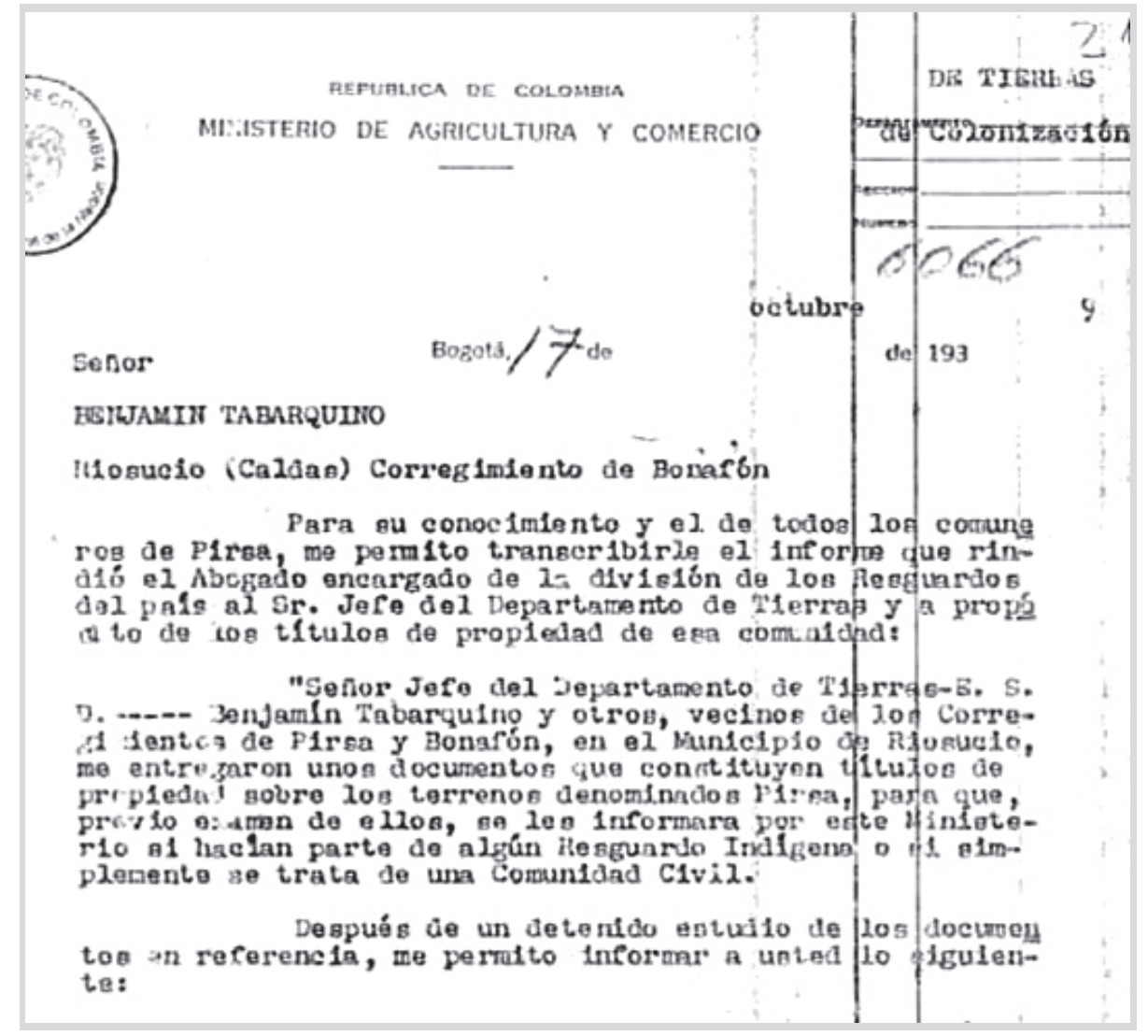

Encabezado de la carta del Ministerio de la Economía a la comunidad de Pirza, con la respuesta del abogado. 17 de octubre de 1939.

Este condominio indígena, proveniente de la época de la Colonia y que estuvo en funcionamiento pleno hasta la década de 1950, cuando renunció el último administrador, Jesús María Peña, nunca se disolvió legalmente.

\section{Visita antropológica de Luis Duque Gómez a Riosucio en 1943}

Paradójicamente, al propio tiempo que el Ministerio de la Economía Nacional procedía a disolver los Resguardos indígenas del país, el Gobierno de Eduardo Santos fundó el Instituto Etnológico Nacional para investigar y proteger a los pueblos 
indígenas ${ }^{107}$. Esta contradicción resultó evidente en el Departamento de Caldas, cuando el Instituto mencionado envió al arqueólogo y antropólogo Luis Duque Gómez a Riosucio a inventariar el estado de las comunidades indígenas, el mismo año de 1943 en que el jefe de Tierras del Ministerio de la Economía, Honorio Salazar, despotricaba contra la Ley 89 de 1890 y el abogado Rey Zúñiga hacía en campo el trabajo de convencer a los indígenas de San Lorenzo de aceptar su extinción.

La tensión entre tan antagónicas políticas oficiales motivó que el Instituto Indigenista de Colombia expidiera una resolución en que "manifiesta la profunda extrañeza por la forma y el criterio con el que el Departamento de Tierras del Ministerio, pretende disolver los resguardos indígenas". ${ }^{108}$

Duque Gómez presentó un primer informe de su visita al Viejo Caldas el 16 de agosto de 1943, en cuanto regresó a Bogotá. Posteriormente publicó en extenso su investigación en la Revista del Instituto Etnológico Nacional.

En el informe del 16 de agosto, Duque destaca que las poblaciones menos mestizadas de Riosucio son la de San Lorenzo y la de Los Chancos (La Montaña) y alcanza a advertir el peligro que para la integridad étnica de San Lorenzo se deriva de la declaratoria de inexistencia de su Resguardo:

De la vereda "El Oro", pasó la comisión al corregimiento de San Lorenzo, en el mismo municipio. Allí vive en la actualidad una población de 4.500 indígenas, organizados en comunidad y amparados por la Ley 89 de 1890. Precisamente, hace solo dos meses, el Ministerio de la Economía dictó una resolución en virtud de la cual se declara inexistente este resguardo y se considera a sus miembros en calidad de colonos; actualmente se están dando los últimos pasos para posesionarlos de sus parcelas. De este modo, nuestra visita a esta Parcialidad fue muy oportuna, pues estamos seguros de que una encuesta antropológica realizada en esta misma zona después de algunos años no dará los mismos resultados que obtuvimos nosotros, toda vez que el régimen de

107 "La ciencia del hombre, como llamó Rivet a la etnología, no figuraba como materia de estudio en los centros universitarios de Colombia. Solamente en la Escuela Normal Superior (creada por la Ley 39 de 1936), un científico alemán, el profesor Justus Wolfram Schottelius, que había huido del nazismo en años anteriores, dictaba la cátedra de etnografía, ocupaba además el cargo de curador del museo arqueológico y etnográfico del Ministerio de Educación y adelantaba investigaciones históricas y etnográficas en Santander. Poco tiempo después, en 1941, año de la muerte de Boas, llegaba al país el científico francés Paul Rivet que al igual de Schotellius escapaba del nazismo-, invitado por el presidente de la república, Dr. Eduardo Santos, con el encargo de establecer una escuela moderna de etnología. En la Escuela Normal Superior nació así el Instituto Etnológico Nacional, con un profesorado que, además de Rivet y Schotellius, incluía a Gregorio Hernández de Alba, José de Recasens y a varios de los maestros que figuraban en la nómina de la Escuela" (Roberto Pineda Giraldo. "Inicios de la antropología en Colombia", en: Revista de Estudios Sociales. Bogotá, Universidad de los Andes, junio de 1999).

108 CO.AGN.SR.60A.30.2.4.1 / [Cauca: adjudicación de baldíos, estado y división de los resguardos] (1933 / 1946). folios: 1-270 Signatura de procedencia: Caja antigua 185, Carpeta antigua 1553. 
resguardos constituye en buena parte una fuerte barrera para la penetración blanca por las vías legales ${ }^{109}$.

En el Departamento de Caldas la comisión empezó su trabajo por Guamal (Supía), donde aplicó el método en boga por la época de determinar la pertenencia étnica por medio de muestras sanguíneas. De 119 pruebas practicadas concluye que hay un cruce entre negros de Guamal e indígenas de San Lorenzo, pero que domina la sangre indígena porque la de los negros es muy débil y tiende a perderse en el cruce con otras razas. El grueso de la investigación se centró en Riosucio, donde Duque anotó que la población indígena está distribuida de la siguiente forma: San Lorenzo (5.000), La Iberia o Cañamomo (2.500), La Montaña (3.000) y Bonafont (3.000). En el sector de El Oro de la parte alta de Riosucio hizo varias excavaciones arqueológicas, hallando numerosas tumbas indígenas, que comprobaban la numerosa población nativa que allí vivía, y sobre su situación para 1943 observó:

Hasta hace algún tiempo estos terrenos estaban ocupados por indios de la Parcialidad de La Montaña, posiblemente los descendientes directos de los constructores de estas tumbas. Recientemente un atropello cometido por algunos blancos de mala fe terminó con el despojo injustificado de estos naturales, los cuales se vieron obligados a recluirse en otra de las zonas de la Parcialidad. Actualmente está asentada allí una colonia antioqueña.

De San Lorenzo anotó que "estos naturales olvidaron por completo su lengua y sus costumbres primitivas, pero conservan el tipo antropológico indígena de manera bastante nítida", lo que en su metodología se demuestra por el predominio del $97 \%$ de sangre tipo "O". También le llama la atención el afán del Cabildo por "por levantar el nivel educativo de los miembros de la Parcialidad".

En Bonafont Duque Gómez encontró un ligero mestizaje (93\% de tipo de sangre indígena) y observó que esta es una zona:

en donde viven agrupados, ya no en parcialidad sino en comunidad, unos 3.000 indígenas. Están gobernados por un administrador, cuya función principal es velar por el patrimonio de la colectividad, que son las tierras comunales. En este grupo se advierte ya un ligero mestizaje, sin que esto quiera decir que no predominan los caracteres indígenas.

La anotación correspondiente a La Montaña expresa:

Pasó luego la comisión a la Parcialidad de La Montaña, cuyos dominios empiezan desde el oeste del área urbana de la población de Riosucio. Allí viven los descendientes directos de los Pirsa, de que tanto nos hablan las crónicas. Como en San Lorenzo y Bonafont, estos indígenas olvidaron por completo casi

109 Biblioteca del Instituto Colombiano de Antropología e Historia (ICANH). Bogotá. 
todo el patrimonio de su cultura tradicional, pero conservan muy puras las características de la raza indígena. Esta población de naturales está distribuida en las veredas de Los Chancos y Kácabrga [Cábarga] y en los corregimientos de Puebloviejo y El Salado; el total de indígenas empadronados llega a unos 3.000. Los más primitivos son los que viven en Los Chancos, que es la porción más occidental de la Parcialidad. Conservan una que otra de sus costumbres tradicionales, su banda típica y la pureza de su raza. La encuesta sanguínea se elaboró precisamente en esta vereda [91.15\% de tipo de sangre 'O'].

De Quinchía dice el informe que es el segundo baluarte de raza indígena, y plantea la hipótesis que no descienden directamente de los Pirza sino de indígenas que habrían emigrado de La Montaña. Sobre la población dice: "De los 14.000 habitantes con que cuenta este municipio se calcula que 8.000 por lo menos son de pura sangre indígena”. Por nuestra parte observamos que si en 1884 sólo había un antioqueño en Quinchía (dato del viajero Alfred Hettner), quiere decir que en 59 años entraron 6.000 paisas a ese resguardo.

Pero Duque Gómez no se limitó a sangrar a los indígenas de la zona rural. También tomó muestras en el área urbana de Riosucio. La encuesta sanguínea tomada "entre los escolares de las clases altas" concluyó en un 73\% de sangre tipo "O" (indígena), $21 \%$ tipo "A" (blanco) y $3 \%$ tipo "B” (negro), resultados que el investigador atribuye a la influencia "de familias de origen europeo asentadas alli".

En cuanto a la pertenencia étnica en la zona, Duque propone como hipótesis:

"Parece que los indios que se encuentran organizados en comunidades en los municipios de Riosucio, Quinchía y Guática son del mismo origen de los de la familia Chamí; a esta conclusión llegamos después de recoger sobre el terreno un buen número de datos y consultar la tradición que se conserva entre estas gentes". 
7. La reforma urbana de los años treinta a cincuenta y sus efectos sobre la existencia de los Resguardos

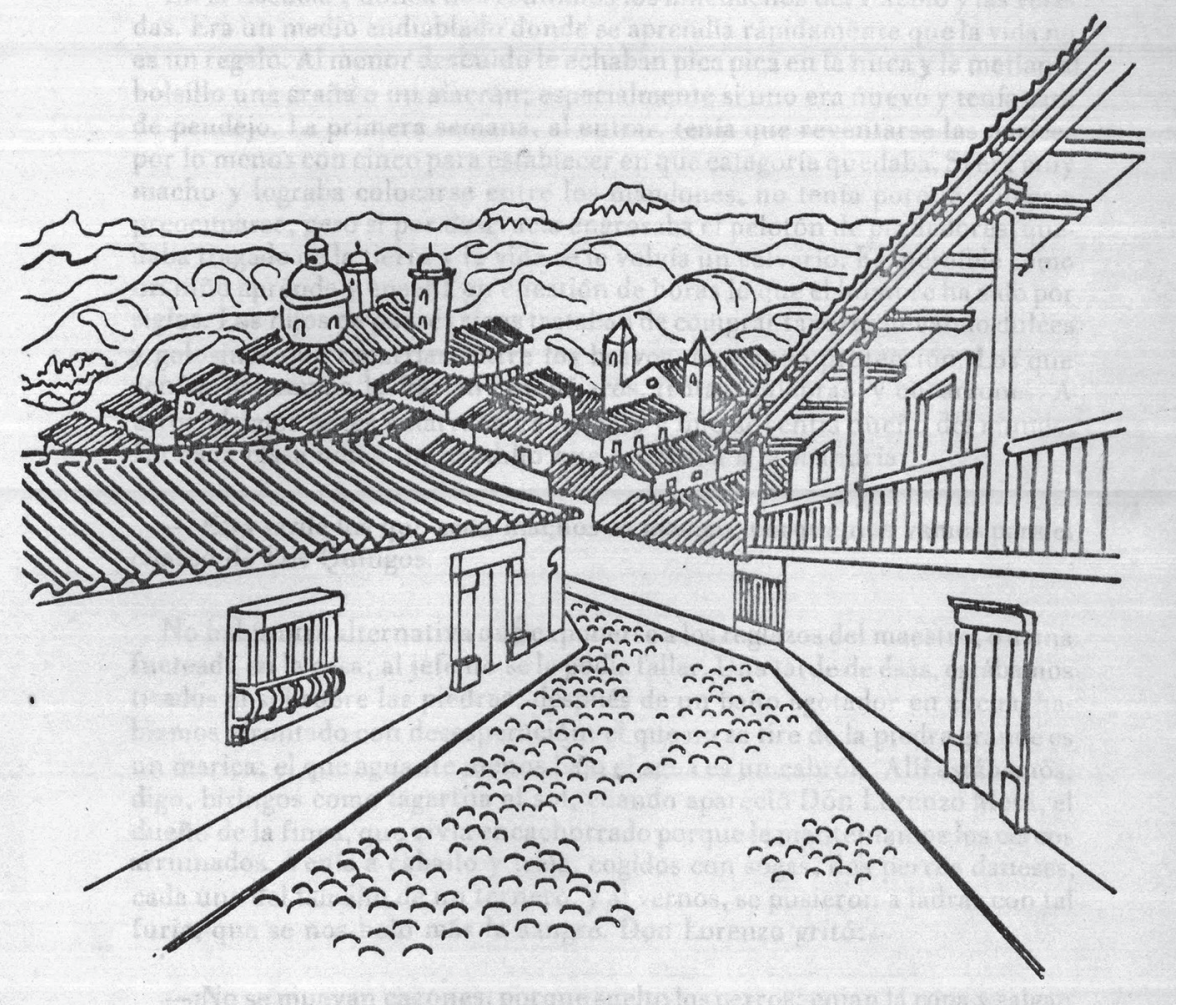

Riosucio. Dibujo de Ariel Escobar Llanos

Para los años 40 ya se había consolidado la lógica de entrar sin preguntar quién era el propietario como una característica del poblamiento de las tierras rurales de Riosucio y de las aledañas al núcleo urbano, como lo dejó consignado en sus crónicas el escritor Rafael Vinasco Trejos:

Después de que los sabios augustos finalizaron el trazado del pueblo, atendiendo la afectuosa petición que les hiciera el ilustre y Reverendo Cura Bonafont, recordando ellos el panorama urbanístico de sus maravillosas urbes; fijados los terrenos para la construcción de las capillas y las escuelas; planificados otros para que en el futuro sirvieran de sitios de expansión y de expresiones culturales y deportivas; y dándole a las calles preciosos delineamientos -con amplitud, sin avaricia-; dentro de su amor por la naturaleza que les era fiel, dispusieron y ordenaron mantener, en gran extensión, unos bosques que alimentaban y conservaban varios arroyos cristalinos. 
De esos bosques, en principio, y por necesidad vital, se extraían: la leña para avivar el fuego del hogar, la madera para la fabricación de elementos y de rústicos muebles que ofrecieran alguna comodidad, y construcción de nuevas casas para albergar una poderosa inmigración de gentes que pensaban situar su existencia en una nueva tierra, guiadas por la ilusión de alcanzar un feliz porvenir y fundadas en las historias y las fantasías que de esa tierra se hacían, debido a las riquezas que brotaban de su seno fecundo.

Corriendo los tiempos, aquellos bosques de solemne belleza, llenos de trinos, se iban despejando, dejando solamente, una franja para el mantenimiento de las aguas. Sobre los espacios que se iban descubriendo germinaban lozanos pastos, que en las mañanas recibían las húmedas gotas de rocío y al atardecer teñíanse de encantadores coloridos de esmeraldas.

De las tierras descubiertas fueron tomando posesión algunas personas, sin saberse quién o quiénes fueron sus primeros y legítimos propietarios, ni el modo de adquisición: si por mandatos de la Corona, legado, donación, adjudicación, permuta o venta; ni qué títulos demostraban el derecho ni cómo se celebraban los actos de posterior transferencia del dominio. En todo caso -ya disfrutando de esa posesión- sus dueños delimitaban sus fundos por medio de mojones, zanjas, árboles o toscos cercos. Los colindantes ofrecían respeto a esas divisiones.

Posteriormente formaron pequeñas dehesas que dedicaron por su cercanía al poblado, en sitios de descanso o en corrales o "mangas" abiertos al cultivo de algunos frutos o al cuido de animales domésticos, especialmente de ganados destinados a la producción lechera.

Esas mangas que recorrimos cantándole a las tardes, en ocasiones se convirtieron en transitorios lechos de deseos, en campos de combates varoniles, en lugares amplios para aspirar el aire puro, el aroma de las brisas. Por su planicie se abrían senderitos con suaves curvas, por donde transitaban los vecinos, con ahorros de tiempo y de cansancio ${ }^{110}$.

110 "Los límites riosuceños", en: Rafael Vinasco Trejos. Apuntes sobre Riosucio. Edición póstuma de la familia, 2005, págs. 191 y 192. Subrayas fuera del original. De esta descripción resalta el tono despreocupado, poético y alegre, que cubre con un halo de misticismo y nobleza el mar de injusticias que se revela en la forma de hacerse a la propiedad de las tierras y los bosques en el municipio. Otto Morales Benítez, en el prólogo a los Apuntes explica que esta es la forma propia de historiar del autor: "En estas pesquisas -y ello lo comprobará el lector- no buscaba sino aquello que enriquecía la historia local. Se preocupaba de que los hechos se refirieran a actos donde los caracteres fueran de actitudes limpias, con tendencia a lo noble. No destaca lo impuro, lo de torcida vocación, lo que hiriera la memoria del personaje o disminuyera el acontecimiento. No hay una sola frase de tendencia hostil contra nadie los seres y los actos, aparecen con un acento de lumbre humana o de brillo colectivo. Esto acontece así porque Vinasco Trejos escribe con verdadero misticismo por los temas, los protagonistas, los sitios. Él, los ennoblece con su evocación" (Ídem, pág. 11). En este sentido es más crudo en narrar la realidad Ariel Escobar Llanos, en su novela Historias del viento en la cordillera (capítulo 24, asesinato del general Salomón Quijano a manos del indio Delfín Tuberquia), aunque también el relato queda encubierto, esta vez bajo el género de ficción. 
Sobre el escenario que dibuja Rafael Vinasco, y con el trasfondo de estar en desarrollo el proceso liquidatorio de los Resguardos indígenas, llegó el progreso a Riosucio de la mano de la construcción de la Carretera Troncal de Occidente (tramo La Virginia - Supía), a cuya inauguración el 31 de julio de 1933 arribaron a la ciudad el ministro de Obras Públicas y los gobernadores de los departamentos de Caldas, Antioquia y Valle, siendo el de Caldas el riosuceño Jorge Gartner.

No deja de llamar la atención que en el discurso inaugural, escrito por el poeta José Trejos, se diera por zanjada con la carretera la discordia con Manizales:

Con esta obra de perfil inconfundible el gobierno central de Manizales borró de un solo brochazo la impresión adversa que habíamos tenido de aquella ciudad, la cual ha resistido invulnerable nuestros apóstrofes con la misma elegancia con que se viste la túnica roja de las almas ${ }^{111}$.

Del aspecto y las costumbres de lo que era Riosucio antes que llegara la carretera es elocuente testimonio la novela Historias del viento en la cordillera, del escritor Ariel Escobar Llanos ${ }^{112}$, una obra concebida en la misma clave narrativa que Cien años de Soledad ("recrear la vida de una comunidad a escala humana, enclavada en la cordillera, en ese mundo mágico, poblado de espejismos, que aparecen al golpe de la luz y el paso de las nieblas. Antes de que irrumpiera la urbanización en Colombia"), y escrita con la naturalidad con la que un viejo recuesta su silla en la pared para contar historias, o, como dice el propio autor, "velando el fuego" en la cocina de las casas, alrededor del fogón de tulpas alimentado con leña de los montes, como se contaban las historias antes que la electricidad espantara los espantos.

En 1942 quien visitaría el pueblo abierto al mundo por la carretera, sería el presidente de la República en ejercicio, Eduardo Santos.

Lo de "abierto al mundo por la carretera" no es retórica. Eso significó la obra pública nacional de la Carretera Central de Occidente. Por ejemplo, del extranjero empezaron a llegar turistas debidamente organizados y no sólo osados viajeros individuales. Poco después de abierta la carretera hasta Medellín salió de esa ciudad una excursión de jóvenes mujeres universitarias estadounidenses que estaba de gira por Colombia. En el grupo viajaba también la escritora española Carmen de Zulueta, quien describió en sus memorias el paso por Riosucio, parada obligada en un viaje que terminaría en Bogotá, que para ella (no se sabe si por española o por venir del nuevo imperio), todavía era Santafé de Bogotá:

111 “Una página del poeta José Trejos”, en Atalaya, Manizales, enero de 1939, pág. 8.

112 Ariel Escobar Llanos. Historias del viento en la cordillera. La primera edición fue publicada en 1980 por la empresa Seguranza, de Bogotá, e incluye treinta y dos ilustraciones de la mano del mismo autor. La segunda edición es de 1989, con sello de la Editorial Lealon de Medellín. 
Otra vez en el bus, un modelo bastante antiguo e incómodo, alquilado a alguna 'flota' local, corrimos por carreteras sin asfaltar, llenas de polvo, pasando ranchitos pequeños con algún perro ladrador, alguna cabra, y siempre niños morenos semi-desnudos, mirando pasar los coches por la carretera. El campo era muy hermoso, la vegetación tupida, llena de buganvillas rojas y moradas, que cubrían cercas y paredes. Estaba muy poco poblado; no había aldeas ni ciudades. Cerros altos, montes, casi desiertos, nos rodeaban. Al llegar el anochecer, paramos en las afueras de un pueblo llamado Río Sucio. No hay que añadir mucho a su nombre para describir el pueblo: casuchas, calles por las que corría una alcantarilla abierta que iba a dar a un turbio y sucio río. Creo que allí, Fred, nuestro guía, compró pan, quizás otras comidas, frutas o verduras, no recuerdo bien. Lo que sí recuerdo es que acampamos como gitanos en las afueras del pueblo. Que encendimos una gran hoguera para calentar la comida, que comimos no recuerdo qué, y que después de comer, ya de noche, colocamos nuestros sacos cerca de la hoguera y tratamos de dormir. No teníamos ni tiendas ni mosquiteros en aquel campo húmedo, lleno de mosquitos, moscas y otros insectos (...).

Muchos años después, hablando con Eduardo Santos, ex-presidente de Colombia y muy buen amigo mío, le conté mi viaje en el Experimental y cómo habíamos pernoctado al aire libre en Río Sucio. Santos no lo podía creer. Conocía ese pueblo y pensó que era imposible que alguien en sus cabales, hubiera ideado tal plan.

De Riosucio seguimos cordillera arriba, cada vez con más polvo, por terrenos áridos y fríos, hasta que un día llegamos a la sabana y poco después, a Santa Fe de Bogotá ${ }^{113}$.

Entre la carretera, el triunfo del liberalismo y las demandas universales que convocaba el siglo XX Riosucio entró en una etapa de transformación del casco urbano y de su entorno acorde con las tendencias predominantes en la época.

En las reformas pueden distinguirse aspectos como:

- Definición del área urbana conforme al derecho común

- Desarrollo de la infraestructura urbana de ciudad moderna, en avenidas, servicios públicos, equipamientos urbanos, etc.

- Incorporación del suelo rural a la economía mediante la disolución de los Resguardos indígenas

- Integración al Occidente con la carretera troncal

- Recuperación de Marmato y demás minas de oro para los mineros de la región.

113 Carmen de Zulueta Cebrián. Caminos de España y de América, Madrid, Ed. Residencia de Estudiantes, 2000 (https://books.google.com.co/books?isbn=8483711575). 
La revista manizalita Atalaya le dedicó el número de enero de 1939 a Riosucio, o más propiamente, al progreso de Riosucio, en cuyas columnas se exaltaron el origen mítico de la fundación; la riqueza aurífera, agrícola y ganadera de la tierra; la vena literaria: el lustre y proyección de sus hombres, y la "belleza gitana" de sus mujeres. En sus páginas abundan la denostación del pasado y los llamados a la acción, a derrotar el pesimismo y a ponerle puntales nuevos al municipio. En fin, la revista retrata un pueblo donde el discurso de la modernidad circulaba con entusiasmo entre plaza y plaza.

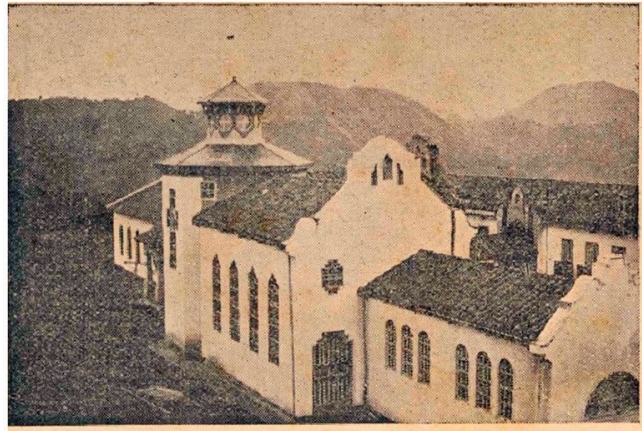

Visla parcial del Hospital de San Juan de Dios. Riosucio.

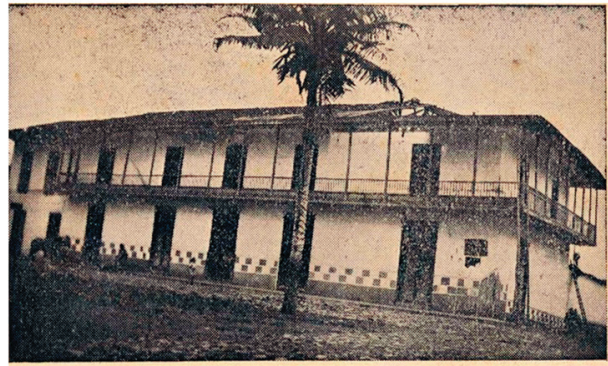

Edificio Deparfamental mandado derribar bajo el Gobierno del doctor Londoño Palacio y cuyos escombros constituyen un estigma para cualquier gobierno.

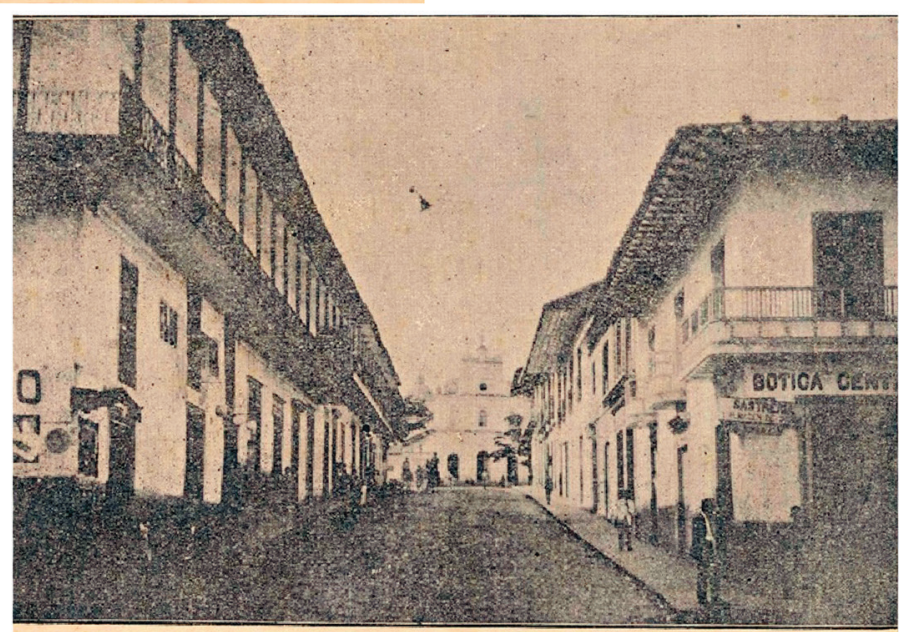

Riosucio.-Calle del Comercio. Se destacan edificios de antigua construcciòn, pero de gran solidez.

Ilustraciones de la revista Atalaya

El ingeniero Gabriel Llanos García, a la par que se ocupaba de sus labores en la Comisión Divisoria del Resguardo de San Lorenzo, escribía para Atalaya las páginas dedicadas al desarrollo urbano, bajo la lógica de superar el aspecto y las costumbres aldeanas que hasta entonces presentaba Riosucio, como lo expresa en su propuesta de aplazar la construcción de la plaza de mercado y empezar por construir la plaza de ferias: 
...no hay razón para que a estas horas tengamos que hacer la feria semestral ocupando todas las calles y plazas de la ciudad, presentando un aspecto de atraso, de desaseo y de inseguridad para los asociados. Solamente a los gotosos se les ocurre que dos mil reses tengamos que soportarlas dentro de las plazas y calles más centrales de la ciudad, que aquello de plaza de feria los obligaría a moverse de sus casas para ver o intervenir en el movimiento de las operaciones ${ }^{114}$.

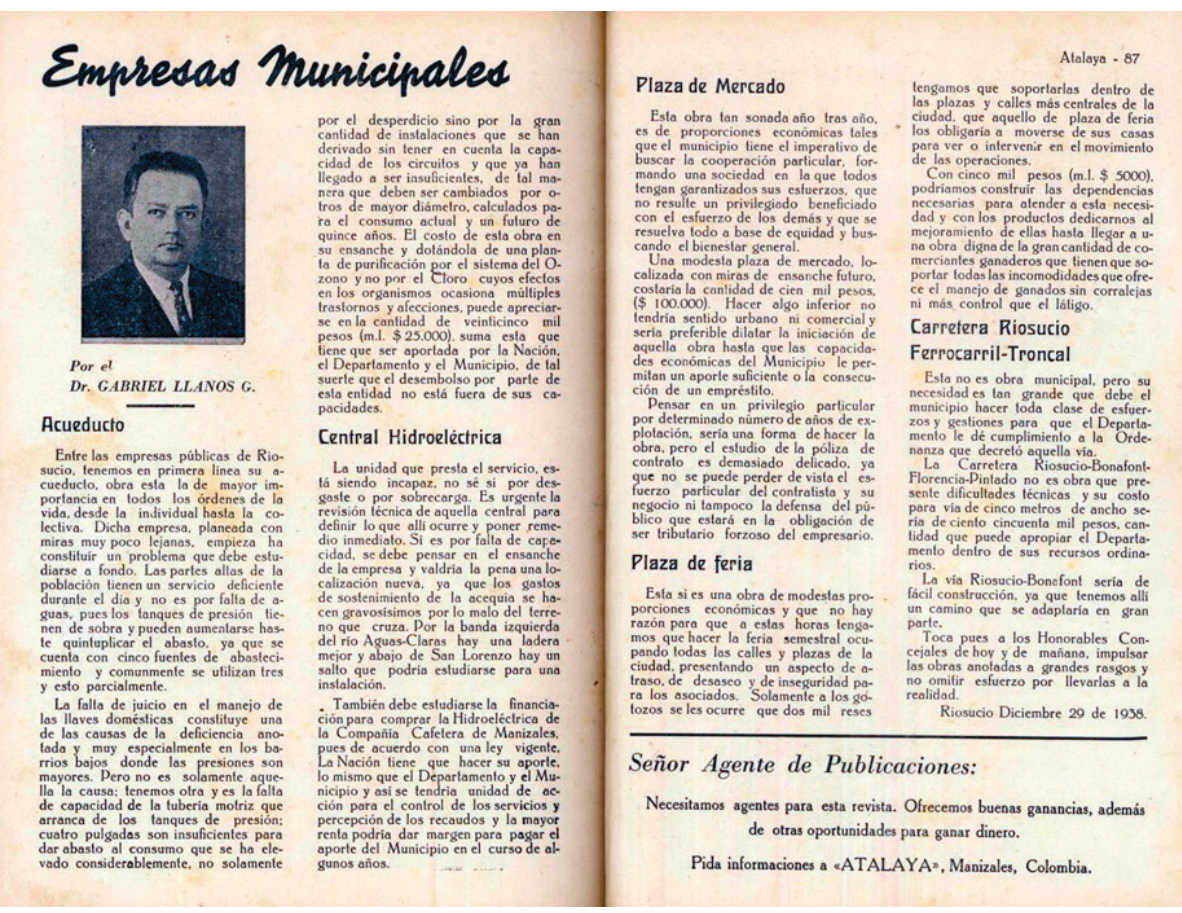

Artículo del ing. Gabriel Llanos

En el imaginario modernista de la época no tenían lugar los indígenas. Por el contrario, los habitantes urbanos pugnaban por sacudirse lo que para ellos era un estigma racial utilizado con sorna desde Manizales.

Antes éramos un pueblo orgulloso y ególatra. Aquí se mellaba el cuchillo del invasor bárbaro. Pero hoy vivimos solemnes abulias y ya no nos conmueve ni el insulto. Viajeros bellacos buscan en nuestra tierra el indio de 'paruma'. Aquí, en la plaza pública, hemos oído la pregunta homicida: ¿dónde están los indios? ¿Es que aún somos de 'tambo'? Llevamos sangre india, como la lleva toda Colombia, y ese es nuestro mayor orgullo. Nosotros repudiamos

114 Gabriel Llanos G. “Empresas municipales”, en: Atalaya, Op cit., pág. 90. Para más información sobre las antiguas ferias de ganado y las anécdotas asociadas a ellas, véase la crónica escrita en 1993 por Rafael Vinasco Trejos, incluida en su obra Apuntes sobre Riosucio (ed. 2005). 
las sugerencias irónicas. Por eso queremos una ciudad fuerte y respetada que ponga a salvo sus blasones ${ }^{115}$.

Pero el querer pugnaba con la realidad, tanto física como jurídica. Por más que bajo la presión universal de la modernidad se quisiera negar el componente ancestral en Riosucio, la existencia de parcialidades y resguardos indígenas en este municipio era un hecho notorio, como lo registraba para el mismo año del 39 el citado informe del abogado del Ministerio de la Economía Nacional, que dio pie a iniciar el proceso de disolución de San Lorenzo, al rechazar la tesis sostenida por el presidente del Concejo Municipal de que los resguardos estuvieran abandonados:

nunca podrá decirse que los resguardos de Riosucio han estado en esas circunstancias, porque la posesión material ejercida por los indígenas sobre ellos es notoria, y porque los Cabildos de 'San Lorenzo', 'La Montaña' y 'Cañamomo y Lomaprieta' nunca han dejado de existir, según así puede comprobarse en los libros de posesiones de esas entidades, que se llevan con cuidadoso esmero en la Alcaldía de ese lugar ${ }^{116}$.

Sin embargo, las complicaciones y demoras para disolver legalmente el Resguardo de San Lorenzo y la negativa de los Cabildos de La Montaña y Cañamomo a acogerse al programa de disolución, condujeron a que a partir de 1942 las autoridades municipales cogieran por la calle del medio y empezaran a administrar el territorio urbano y rural haciendo abstracción de la legislación especial indígena. En este sentido se impulsó la desaparición jurídica del Resguardo de San Lorenzo, se demarcó un nuevo perímetro urbano sin celebrar convenio con los Cabildos de La Montaña y de Cañamomo, se hizo cesar el funcionamiento en colectivo de los terrenos de Pirza Bonafont, se decretaron impuestos sobre los predios de los indígenas y se expidieron escrituras privadas superpuestas a los títulos de los Resguardos.

Ya se vio que en febrero de 1942 el ingeniero Gabriel Llanos García animaba al Ministerio de Economía Nacional a proceder "en cualquier forma sea legal o arbitraria" a la disolución del Resguardo de San Lorenzo, el que, en efecto, fue declarado inexistente al año siguiente, al mismo tiempo que el ingeniero fue nombrado Personero Municipal. ${ }^{117}$.

115 Luis Carlos Obando, “Carteles”, en: Atalaya, Op cit., pág. 90. En el mismo artículo su autor explicita la perspectiva de sus reflexiones: "Escribir sobre las ciudades y los hombres puede resultar peligroso y exasperante cuando no hay en el entendimiento gravedad e inclinación a la crítica amplia y dilatada y, cuando, por otra parte, se desconoce aquello que pudiéramos llamar sensibilidad histórica, concebida ésta como el termómetro de los hombres a través de sus hechos singulares. Siempre hemos pensado que la historia, con sus claridades y confusiones, constituye la comprobación e interpretación más segura para acercarse un poco a las realidades de las razas y al calor subiente de los pueblos"

116 Adolfo Romero, informe del 29 de septiembre de 1939 (AGN citado).

117 Aunque en Riosucio no fueron declarados inexistentes más resguardos que el de San Lorenzo, los políticos locales sí promovieron y obtuvieron la extinción de los resguardos vecinos de Quinchía (1948) y Guática (1954). 
El 17 de marzo de 1942 el Concejo Municipal adoptó el "área urbana general de la ciudad" conforme al derecho común, dejando de lado la figura especial de "área de población" reglamentada por el mismo Concejo cincuenta años antes:

Determínase por área urbana general de la ciudad la conocida por los linderos siguientes: Desde la cruz del cerro del Ingrumá hasta el alto de Medina; de aquí hasta la piscina de El Edén; de este lugar hasta el alto del Ojo de agua, donde se encuentra la capilla del Carmen; de este punto hasta la escuela de Sipirra, partiendo de esta y siguiendo la cimera de la cuchilla del mismo nombre, hasta la capilla de Tumbabarreto, y de aquí línea recta, hasta encontrar el primer punto de partida" (Acuerdo $\mathrm{N}^{\circ} 12$ de 1942, artículo 16).

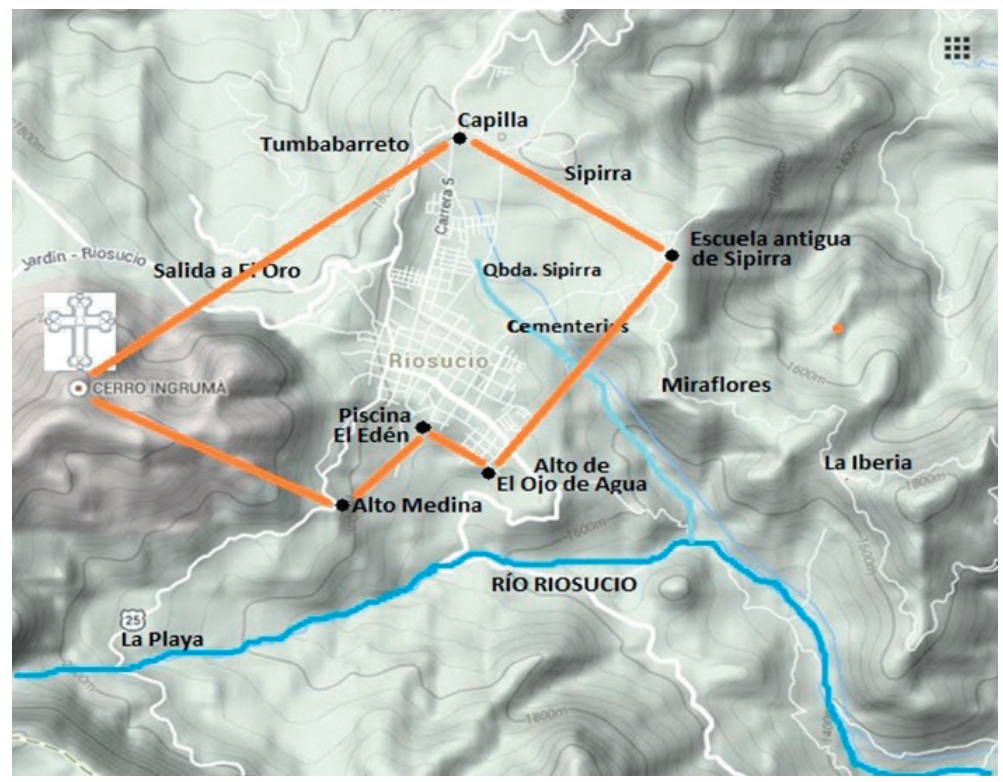

Mapa del área urbana de 1942

La nueva delimitación se hizo a partir del cerro tutelar de la ciudad, al que ya para entonces Enrique Palomino Pacheco le había dedicado el poema "Mi delirio sobre el Ingrumá" y en cuya cima se había levantado en 1933 la actual cruz de concreto, pese a que este lindero quedaba por fuera del área de población acordada con el Cabildo de La Montaña en 1873 y reglamentada por el Acuerdo $\mathrm{N}^{\circ} 2$ de 1890. Pero en cualquier caso, a diferencia del "área de población", el "área urbana" del Acuerdo de 1942 se trata de una figura netamente urbanística sobre uso del suelo, por lo cual no afectaba entonces ni afecta hoy los derechos del Resguardo sobre el cerro (además, el cerro fue excluido nuevamente del área urbana en el PBOT de 2003). 

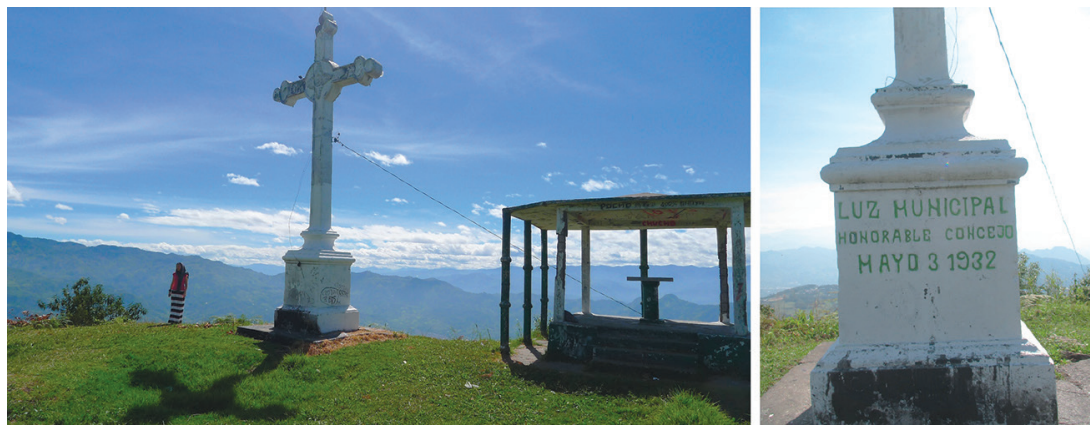

Cruz del cerro Ingrumá

La tercera medida, el establecimiento de impuestos a los indígenas, motivó que el 10 de abril de 1944 el Cabildo de La Montaña le dirigiera una carta al Procurador General de la Nación en la cual le expuso que por ser Resguardo los indígenas no son propietarios sino usufructuarios de sus parcelas, por lo que están exentos del impuesto predial que es solo para propietarios; pero que el Concejo Municipal les estaba imponiendo a los miembros de la parcialidad contribución predial y otros gravámenes que los indígenas no podían pagar "y que por otra parte considero ilegales". Entonces le pide al procurador que intervenga ante el Concejo para obtener la exoneración de impuestos, no sin antes dejar consignado que se dirige al despacho del Procurador porque el Concejo Municipal nunca atiende a los indígenas "por más razones de peso que le exponen en justicia" ${ }^{118}$.

En cuanto a la expedición de escrituras públicas al interior de los Resguardos, este aspecto se refiere al caos legal en la titulación de las tierras rurales que siguió a la desterritorialización provocada por las autoridades públicas de Riosucio, cuando al decir de mayores como don Manuel Morales del Resguardo de Escopetera Pirza, don Marco Fidel Largo del Resguardo de La Montaña, don Silvio Tapasco Aricapa del Resguardo de San Lorenzo y don Ernesto Tapasco del Resguardo de Cañamomo Lomaprieta, los políticos locales recorrieron los campos diciéndole a los indígenas que tenían que sacar escrituras públicas porque si no lo hacían iban a perder sus tierras.

118 Expediente de división de San Lorenzo (AGN citado). Según el acta de posesión, incluida en el mismo expediente, para 1944 el Cabildo de La Montaña estaba conformado así: Gobernador: Juan Román Pescador; alcalde $1^{\circ}$ : José Evaristo Bañol; alcalde $2^{\circ}$ : José Cándido Pescador; regidor $1^{\circ}$ : Félix A. Bañol; regidor $2^{\circ}$ : Leonardo Bañol; vocal $1^{\circ}$ : Ramón Elías Morales; vocal $2^{\circ}$ : Prudencio Pescador. 

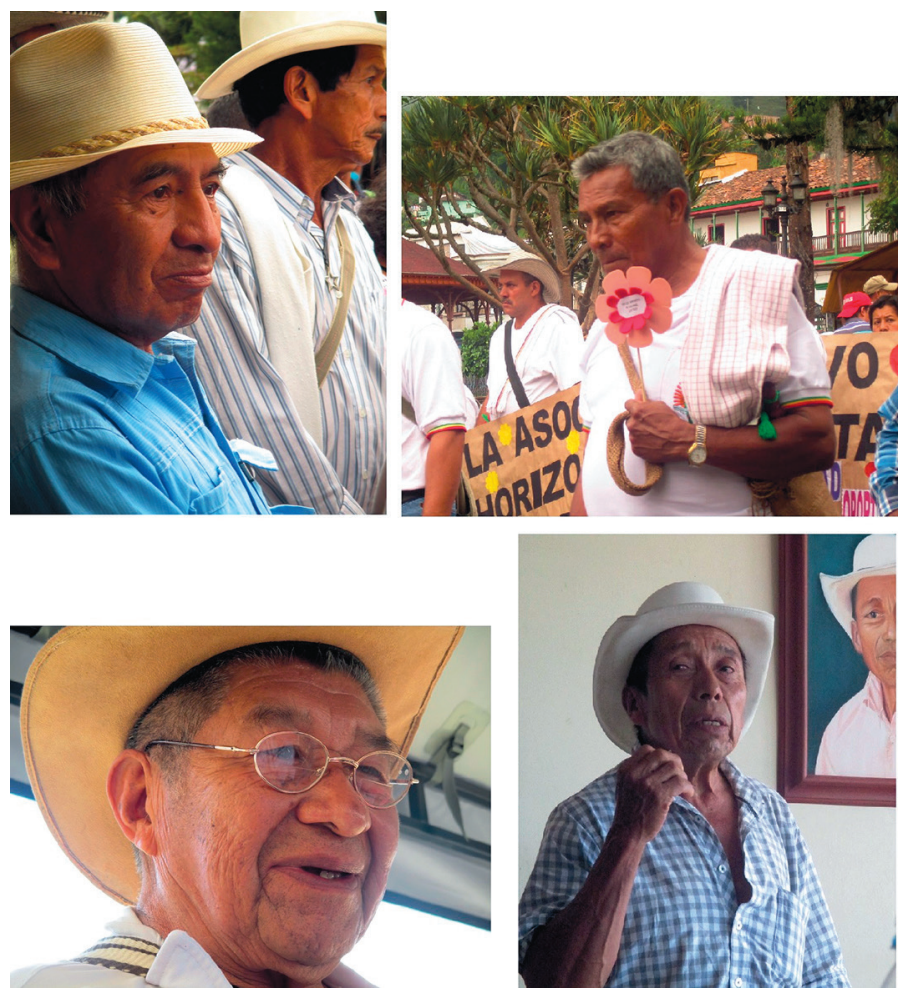

Arriba: Marco Fidel Largo y Ernesto Tapasco Abajo: Silvio Tapasco y Manuel Morales

Estos testimonios tienen respaldo documental, porque el 9 de diciembre de 1953 un grupo de indígenas de La Montaña puso en conocimiento del Ministerio de Agricultura (sucesor del desaparecido Ministerio de la Economía Nacional) la gravedad de la situación, ya que, según ellos:

individuos que se dicen representantes del Gobierno Nacional están explotando en la actualidad el campesinato mediante el cobro de crecidos emolumentos o contribuciones, dizque para parcelar, revisar títulos, declarar la validez o nulidad de éstos, sin que sepamos a ciencia cierta si efectivamente son los representantes del Gobierno a cuyo nombre dicen actuar ${ }^{119}$.

119 Memorial del 9 de diciembre de 1953 dirigido al Ministerio de Agricultura (ya había desaparecido el de Economía Nacional) solicitando la extinción y parcelación del Resguardo. El memorial, escrito en papel sellado y autenticado por el Juzgado Promiscuo Municipal, lo firman: Pascual Motato, encabezando, seguido por José Domingo, Julio, Luis Ángel, Luciano, José Cipriano, José Manuel, Carlos Emilio, Eleuterio, Juan Andrés, Clemente, Francisco Luis y otro Francisco Motato, y además: Francisco Morales, Ruperto Bañol, Andrés Largo, Octaviano Largo y Jesús Gañán. El grupo actuaba en nombre propio, debido a que el último gobernador había muerto en 1950 y el Cabildo había quedado cesante. 
El texto de esta carta es muy llamativo, porque aunque es firmada por indígenas parece reflejar más bien (o también) los intereses de los habitantes urbanos y de los colonos rurales. Los firmantes motivan la solicitud de extinción en razones como: 1) que debido a lo antiguo del resguardo y pese a su extensión de miles de hectáreas, la población ha crecido y ya no hay terrenos incultos para que el Cabildo siga haciendo adjudicaciones de parcelas de acuerdo con la Ley 89 de 1890;2) que el Cabildo está en receso desde hace tres años por la muerte del último gobernador; 3) que el Cabildo ya no tiene funciones "puesto que todas las tierras de su resguardo están ocupadas por partícipes" (no menciona en ninguna parte las ocupaciones de los particulares); 4) que los indígenas hace mucho tiempo que están civilizados, pero la Ley 89 de 1890 no les permite enajenar las tierras del resguardo; 5) que por este motivo están fuera del comercio miles de hectáreas cultivadas con café, pasto artificial y otras plantaciones agrícolas, con grave perjuicio para la economía pública; 6) "que las ventas que se efectúen sin sujeción a tales leyes ( 89 de 1890 y decreto reglamentario 74 de 1898), adolecen de nulidad, y son motivo de múltiples conflictos de derecho que es necesario evitar"; 7) que el término de 50 años establecido en la Ley 89 para liquidar los resguardos está vencido y se hace necesaria la intervención del Gobierno Nacional para solucionar el asunto; 8) que "individuos que se dicen representantes del Gobierno Nacional están explotando en la actualidad el campesinato mediante el cobro de crecidos emolumentos o contribuciones, dizque para parcelar, revisar títulos, declarar la validez o nulidad de éstos, sin que sepamos a ciencia cierta si efectivamente son los representantes del Gobierno a cuyo nombre dicen actuar", y 9) que hace varios años el Ministerio de la Economía liquidó y parceló el Resguardo de San Lorenzo estimulando el progreso de esa región de manera extraordinaria, ya que le dio tranquilidad a los propietarios y poseedores, sin los conflictos y pleitos en que los tenía sometidos la indivisión. La petición se concreta a que el Ministerio de Agricultura decrete la liquidación de la parcialidad de La Montaña y el repartimiento de las tierras "entre sus miembros o partícipes" (no especifica los particulares), mediante una comisión que liquide y expida los nuevos títulos, todo por cuenta de la Nación como se hizo en San Lorenzo. Termina: "Si el señor ministro necesita una información acerca de la conveniencia del acto que solicitamos, puede dirigirse al sr. Personero de la ciudad o al señor Alcalde Municipal, quienes están enterados del problema o necesidad en que nos encontramos con relación a la indivisión"

Para complicar el ya confuso panorama en materia de titulación de la zona rural del municipio, en 1952 se incendió la Notaría del Circuito de Riosucio y con ella se quemaron las escrituras y demás documentos objeto de protocolización. 


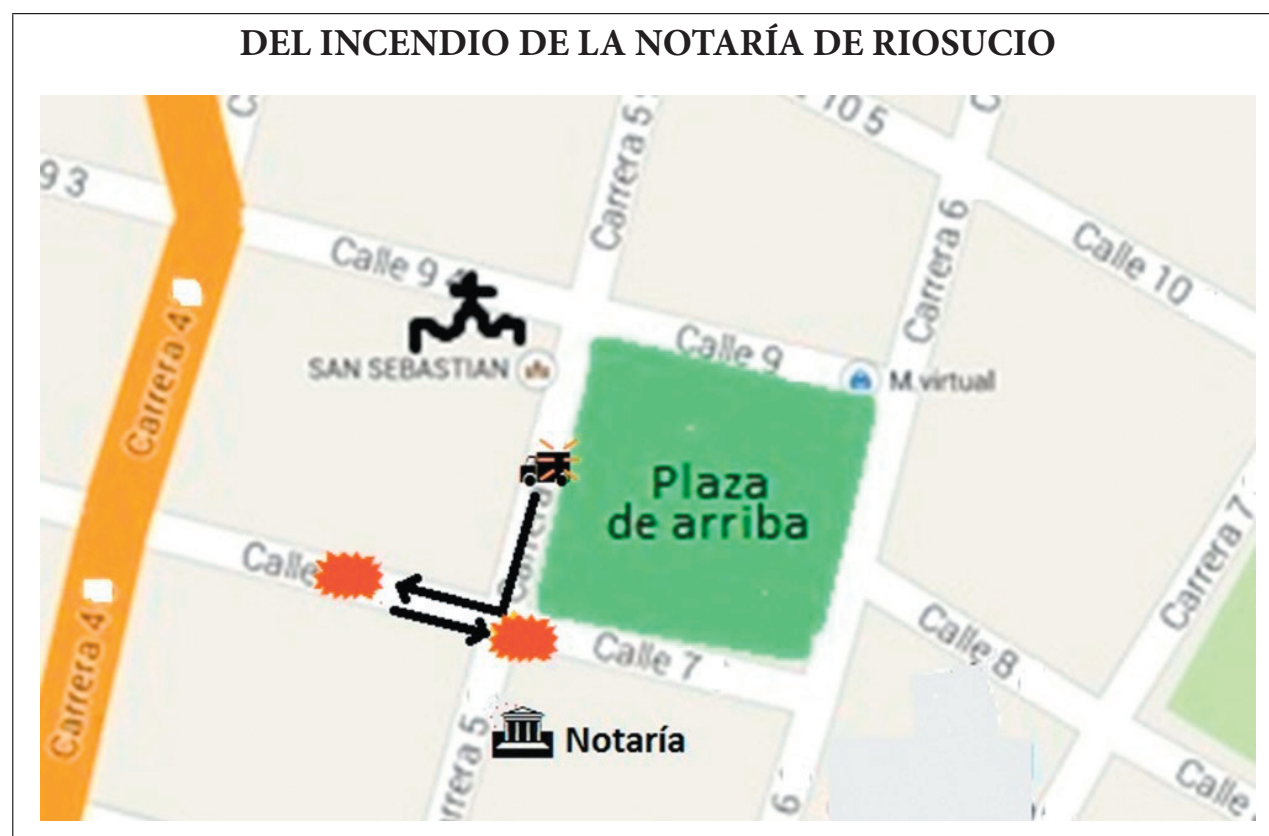

Todo sucedió un sábado de enero de 1952 en la esquina sur-occidental de la Plaza de Arriba, flanqueada hoy por el Café La Fontana, el Club Colombia y la Discoteca Filigranas, que entonces correspondían, en su orden, a las casas de la familia Trejos Espinosa, de los Velascos y de don Alonso García, a quien llamaban "El Mocho". El pueblo estaba en Fiestas de San Sebastián, que en ese tiempo se celebraban con la misma pompa conque hoy se celebran las Fiestas de la Candelaria, y por tanto incluían la quema de una batería de pólvora cada día del novenario.

Sobre la carrera $5^{\text {a }}$ (atrio de la iglesia) estaba estacionado un carro con gasolina, enfrente de donde actualmente funciona el supermercado Nuevo Milenio, el cual fue alcanzado por un volador u otro elemento de pólvora, incendiándose de manera inmediata. El conductor se encontraba dentro del vehículo, y su reacción fue sacar el camión en llamas de la plaza hacia la troncal (carrera $4^{\mathrm{a}}$ ). Dio la vuelta a subir por la calle $7^{\mathrm{a}}$, pero a media cuadra, al frente de la actual casa de doña Gladys Estrada, estalló el tanque de la gasolina. El conductor saltó del vehículo, y éste, desengranado, se devolvió en reversa hacia la plaza. Al llegar a la esquina, estalló del todo y las llamas se extendieron de inmediato a las tres casas adyacentes. Una de ellas era la casa de los Velasco (hoy Club Colombia). Don Oscar Velasco García, que en esa época era un muchacho, y de quien es el presente relato, estaba cerca del lugar y corrió a socorrer a los de su casa. No pudo entrar por la puerta principal que daba a la plaza porque por ahí empezó el incendio. Entonces se dirigió a la puerta lateral, que da a la carrera 5a, subió por las escaleras y en el segundo piso encontró a las mujeres de la familia, a quienes sacó a las volandas por la misma puerta para ponerlas a salvo. Salieron con lo que llevaban puesto. Todo lo perdieron. Igual pasó en las otras casas.

La Notaría quedaba en ese tiempo sobre la carrera $5^{\text {a }}$, enseguida de la casa de la familia Velasco, y también fue consumida por el fuego. El incendio destruyó las escrituras públicas, y con ellas buena parte de la historia de Riosucio y de los municipios aledaños del Circuito. 
Ha sido tan notoria la irregularidad del fenómeno de las escrituras públicas dentro de los Resguardos indígenas que el propio Concejo Municipal de Riosucio, mediante el Acuerdo $\mathrm{N}^{\circ} 035$ del 3 de septiembre de 1965 autorizó al alcalde y al personero a contratar un abogado "para obtener la declaración de nulidad de los títulos que en las parcialidades mencionadas [La Montaña y Cañamomo] se hayan extendido".

Según los considerandos:

No obstante las disposiciones citadas [Decreto 15 de 1828, Ley 89 de 1890, Decreto del 15 de octubre de 1928 y Ley 81 de 1960] en la jurisdicción de Riosucio, con violación de las medidas legales comentadas, se han hecho compras y ventas de las parcelas afectadas con dicha legislación, con colaboración de Notarios y Registradores, quienes han expedido y registrado títulos de propiedad con expresa y flagrante violación de las normas vigentes 120 .

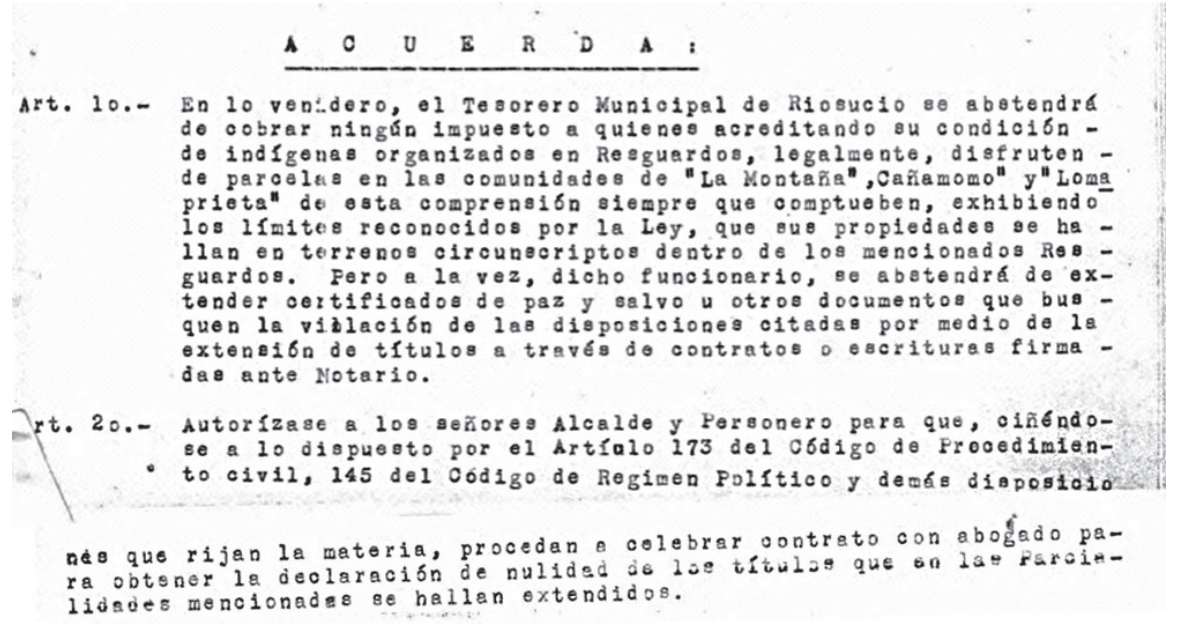

Fragmento del Acuerdo Municipal No. 035 de 1965

\section{Del cambio de política indigenista del Estado en 1958 a la Constitución de 1991}

En 1940 tuvo lugar en Pátzcuaro (México) el Primer Congreso Indigenista Interamericano, realizado con apoyo de la Organización de Estados Americanos (OEA), con el cual comienza a institucionalizarse en el continente americano un cambio en la relación entre los Estados y las poblaciones indígenas, a partir de reconocer su marginalidad política, económica y social. Se trataba de darle apoyo técnico de desarrollo rural a las comunidades, con el fin de conseguir su "aculturación pacífica” y su integración a los patrones de vida del resto de habitantes de los países. 
En Colombia el Congreso aprobó la Convención de Pátzcuaro en 1944, mientras por la misma época se creó el Instituto Etnológico Nacional, dependiente del Ministerio de Educación, el primer intento oficial de conocer la realidad étnica del país. En el sector privado, bajo el impulso del antropólogo Gregorio Hernández de Alba, se constituyó el Instituto Colombiano Indigenista, con fines similares.

El Instituto Indigenista de Colombia, que desde 1943 reunió a los miembros del Instituto Etnológico Nacional, IEN, y a otros intelectuales indigenistas, demostró la errática política del Estado de privatizar los territorios indígenas porque esto les conducía a la servidumbre y a paupérrimas condiciones de vida. Los indigenistas reclamaron la constitución de una oficina dedicada a resolver este "problema indígena" 121 .

El Instituto se desintegró en 1948 con el “Bogotazo” en que murió Jorge Eliécer Gaitán. Superada la época de La Violencia, el Frente Nacional comenzó a dar pasos concretos de reivindicación de la población nativa: La Ley 51 de 1958 dejó de considerarlos salvajes, abrió programas agrícolas a su favor y creó al interior del Ministerio de Agricultura la Sección de Asuntos Indígenas, la cual quedó a cargo de Hernández de Alba; el Congreso aprobó el Convenio 107 de 1957 sobre poblaciones indígenas de la Organización Internacional del Trabajo (OIT), organismo de las Naciones Unidas; en 1960 se creó la División de Asuntos Indígenas adscrita al Ministerio de Gobierno, con oficinas en algunos municipios (la primera se abrió en Riosucio para atender específicamente el conflicto agrario en el Resguardo de Cañamomo); el mismo año el Ministerio de Agricultura constituyó la Reserva Indígena de San Lorenzo, y en 1961 el Congreso aprobó la Ley 135 o Ley de Reforma Agraria, la cual autorizó al INCORA para constituir Resguardos Indígenas en favor de las comunidades que carecieran de tierras o tuvieran insuficientes.

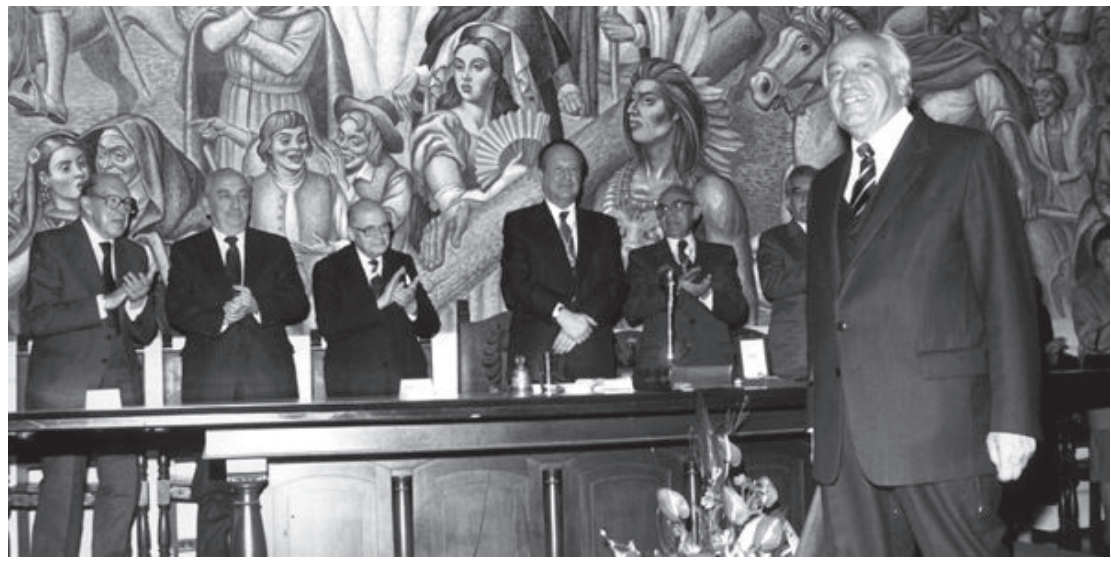

Otto Morales en la Academia Colombiana de la Lengua (foto de internet)

121 François Correa y Sandra Acero. "Proyecciones del Instituto Indigenista de Colombia en la División de Asuntos Indígenas”. Bogotá, revista Baukara, N³, ICANH, mayo 2013. 
Le correspondió al riosuceño Otto Morales Benítez, ministro de Agricultura de Lleras Camargo en 1961, y quien en 1948 había presentado en la Cámara de Representantes el proyecto de ley para la abolición del Resguardo de Quinchía, defender ante el Senado esta función del INCORA:

Queda el INCORA con otra facultad: a solicitud de la División de Asuntos Indígenas del Ministerio de Gobierno, podrá constituir resguardos de tierra en beneficio de grupos o tribus que no los posean. Esta disposición facilita otra actitud: estudiar zonas donde se han producido desplazamientos de indígenas, analizar cómo fueron despojados en otras ocasiones. Es devolver el espíritu comunitario, a gentes que así se enseñaron a vivir, cuyo medio natural de existencia y sistema de agrupación para la producción económica, son precisamente esos ${ }^{122}$.

De manera paralela al reconocimiento de las comunidades indígenas, el Estado propendió por impulsar el derecho de asociación de comunidades urbanas y rurales al autorizar mediante la Ley 19 de 1958 la constitución de Juntas de Acción Comunal. En el corregimiento de San Lorenzo de Riosucio, las Juntas vinieron a llenar el vacío que había dejado la cesación del Cabildo desde 1943. El año 1962 fueron creadas las juntas comunales de Llano Grande, Centro Poblado, Aguas Claras, Blandón, Lomitas, Honduras y Piedras; en el año 1963 las de San Jerónimo y San José; en el año 1965 la de Pasmí; en el año 1971 la de Veneros; en el año 1976 la de Sisirrá; y en el año 1980 la de Playa Bonita. En Cañamomo y La Montaña las Juntas se superpusieron a los Cabildos, que nunca habían dejado de funcionar, aunque de manera casi que clandestina. Igualmente en la antigua comunidad de Escopetera Pirza o corregimiento de Bonafont las comunidades encontraron en las Juntas, y en los políticos a las que estaban ligadas, el mecanismo que permitió el acceso a servicios de escuelas, electricidad, acueducto, etc.

En Caldas, como en el resto de Colombia, la Reforma Agraria se dinamizó a partir de la creación por 1966 de la Asociación Nacional de Usuarios Campesinos (ANUC), movimiento al que se incorporaron activamente los sectores rurales de Riosucio. $\mathrm{Al}$ interior de las luchas por la tierra lideradas desde la ANUC se fue evidenciando que campesinos e indígenas tenían concepciones muy distintas sobre la tierra: los unos como bien material, soporte de una familia, de propiedad individual, sujeta al comercio y destinada a ser explotada hasta su agotamiento; los otros entendían la tierra en una dimensión espiritual y cosmológica, como un bien sagrado, hábitat de un pueblo o comunidad, de dominio colectivo y trabajo comunitario, inalienable y destinado a su conservación para las siguientes generaciones. La misma ANUC promovió que los indígenas salieran de su seno y se organizaran por su parte. De ahí surgieron el Consejo Regional Indígena del Cauca (CRIC) en 1970, la Organización

122 Historia de las Leyes, Legislatura de 1961, Ref. Agraria, Imprenta Nacional, 1966, págs. 558 y ss., en: Fuero Indígena Colombiano, Presidencia de la República, 1990, pág.131. 
Nacional Indígena de Colombia (ONIC) en 1982 y el Consejo Regional Indígena de Caldas (CRIDEC) en 1982.

En esta etapa ocurrió un hecho muy importante en el Resguardo de La Montaña, pues un grupo de jóvenes reemplazó a don Pedro Largo en la dirección del Cabildo, quien en sus veinte años como Gobernador había logrado sostener la organización indígena gracias a su perseverancia y a las alianzas que estableció con la clase política riosuceña (fue concejal del Municipio). Con su reemplazo, un nuevo liderazgo, del que hicieron parte Gilberto Motato y Marco Fidel Largo, entre otros, se propuso recuperar el Resguardo de Nuestra Señora Candelaria de La Montaña. Cuenta don Marco Fidel que en el Ministerio de Gobierno les preguntaban que si la intención de recuperar el Resguardo era entrar a las fincas por la fuerza, como en el Cauca, y que él contestaba que no, que se iban a respetar todas las posesiones, pero que era necesario delimitar el Resguardo, la jurisdicción del Cabildo. En 1984 el Instituto Geográfico Agustín Codazzi, por solicitud del Ministerio de Gobierno, deslindó ese Resguardo ${ }^{123}$.

El proceso de cambio de la política indigenista del Estado adquirió rango constitucional en 1991, cuando la Asamblea Nacional Constituyente reconoció como principios fundamentales de la nueva Constitución el reconocimiento de la diversidad étnica y cultural de la nación colombiana $\left(\operatorname{art.} 7^{\circ}\right)$, así como la igualdad y dignidad de todas las culturas que conviven en el país (art. 70). Ser indígena o negro dejó de ser sinónimo de atraso y motivo de vergüenza y discriminación, y a las respectivas comunidades se les reconoció el derecho de expresarse como pueblos.

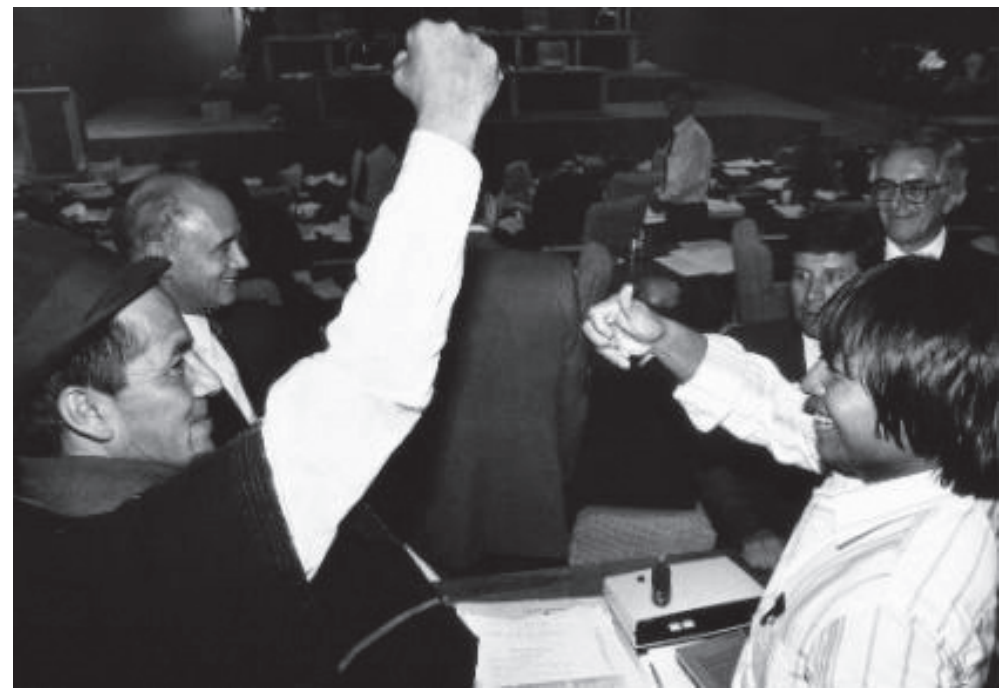

Los indígenas Lorenzo Muelas y Francisco Rojas Birry en la Constituyente

123 IGAC, Subdirección de Catastro Nacional. "Informe de límites. Resguardo de La Montaña (La Montaña y San Lorenzo). Municipio de Riosucio. Departamento de Caldas. 1984”. 


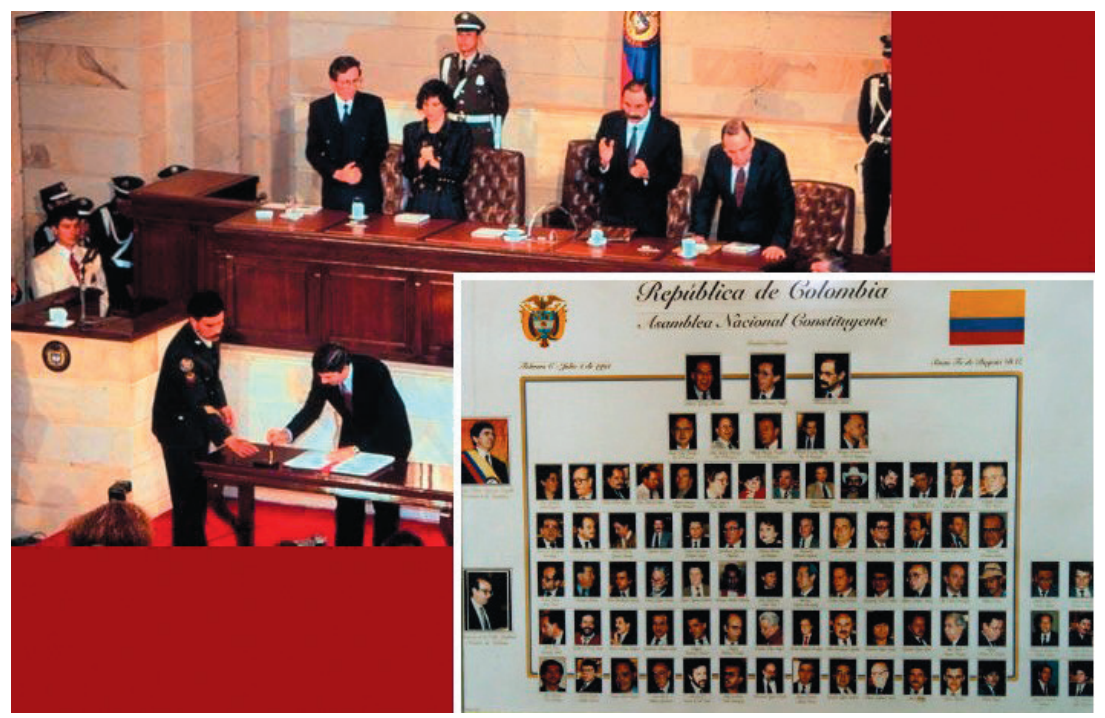

Asamblea Nacional Constituyente de 1991

Simultáneamente con el proceso constituyente, el Congreso de República aprobó el Convenio 169 de la OIT sobre pueblos indígenas y tribales, mediante la Ley 21 de 1991, basado en la autonomía y no en la integración de los indígenas.

Como lo advirtió tempranamente la Corte Constitucional: la diversidad de la nación no era un mero principio teórico, sino que estaba llamado a introducir cambios en la práctica.

Uno de esos cambios era a nivel de la organización territorial del país, nivel en el que la nueva Constitución consagró los Territorios Indígenas como parte de la división político administrativa, y no como una promesa hacia el futuro (como las Regiones y las Provincias), sino como entidades territoriales de vigencia inmediata, como los Municipios y los Distritos (artículo 286).

Riosucio no estuvo exento de estas implicaciones. De esa época data el convenio celebrado entre la División de Asuntos Indígenas (DAI) del Ministerio de Gobierno y el Instituto Geográfico Agustín Codazzi (IGAC) para delimitar los Resguardos de origen colonial del país, el cual produjo en 1994 la revisión de los límites del Resguardo de La Montaña, el deslinde del Resguardo de Cañamomo Lomaprieta, e incluso la delimitación de la parcialidad de Escopetera Pirza, que para entonces solicitaba la constitución de un Resguardo nuevo. En el informe relativo a Escopetera Pirza, al referirse a sus colindantes, se lee:

El resguardo de Cañamomo y Lomaprieta al igual que el resguardo de La Montaña, con los cuales limita el área en consideración para la conformación del resguardo Escopetera - Pirza, tienen sus linderos claramente identificados y sustentados en escrituras públicas o títulos coloniales que los acreditan como 
resguardos, además de haber sido reconocidos como tales por el Ministerio de Gobierno, por las autoridades locales y por la comunidad en general ${ }^{124}$.

Con el cambio de siglo la Junta Directiva del INCORA volvió a constituir el Resguardo Indígena de San Lorenzo (2000) y en el año de 2003 constituyó el Resguardo de Escopetera Pirza.

De otra parte, el Plan de Desarrollo de la Alcaldía de Gladys Estrada de Gutiérrez señaló desde 1994 la necesidad de que Riosucio se preparara para incorporar en la administración del Municipio los territorios indígenas reconocidos por la Constitución de 1991.

El siglo XX terminó sin que se diera esta incorporación, pero la Ley 388 de 1997 había dejado el camino abierto para ello al disponer que todos los municipios del país debían expedir Planes de Ordenamiento Territorial (POT) con vigencia de tres administraciones municipales. En Riosucio se expidió el Plan Básico de Ordenamiento Territorial (PBOT) durante la administración de Cruz Ociel Gartner Restrepo, mediante el Acuerdo Municipal $N^{\circ} 145$ de 2003, en el que quedaron incorporados los territorios indígenas ${ }^{125}$, así:

\section{ESTADO ACTUAL DEL MUNICIPIO DE RIOSUCIO}

La constitución política colombiana establece como entidades territoriales a los departamentos, distritos, municipios y territorios indígenas, definiéndolos de la siguiente manera:

- Departamento: son entidades territoriales que ejercen funciones administrativas, de coordinación, de complementariedad de la acción municipal, de intermediación entre la Nación y los municipios y de prestación de los servicios que determinen la Constitución y las Leyes;

- Municipio: Tal como lo establece la Constitución y la Ley 136 de 1994, el municipio es la entidad fundamental de la división político-administrativa del estado con autonomía política, fiscal y administrativa, dentro de los límites que le señalen la Constitución y la ley y cuya finalidad es el bienestar general y el mejoramiento de la calidad de vida de la población en su respectivo territorio ; y,

- Territorios Indígenas: Las entidades territoriales de los grupos étnicos están conformados por sus territorios de resguardos, sus

124 IGAC. "Informe de límites de la Comunidad Escopetera-Pirza. Municipio de Riosucio - Departamento de Caldas. Municipio de Quinchía-Departamento de Risaralda”. Santafé de Bogotá, 1994 
territorios tradicionales y los que constituyen su hábitat. Tiene un régimen especial de acuerdo con sus formas de organización social, costumbres y tradicionales.

De acuerdo a estas definiciones el municipio de Riosucio determina su estructura territorial de la siguiente manera:

\begin{tabular}{|c|c|c|c|c|c|}
\hline \multicolumn{6}{|c|}{ DEPARTAMENTO DE CALDAS } \\
\hline \multicolumn{6}{|c|}{ MUNICIPIO DE RIOSUCIO - ESTRUCTURA TERRITORIAL MUNICIPAL } \\
\hline $\begin{array}{c}\text { RESGUARDOS } \\
\text { INDIGENAS }\end{array}$ & $\begin{array}{c}\text { PARCIALIDAD } \\
\text { INDIGENA }\end{array}$ & $\begin{array}{c}\text { CENTROS DE } \\
\text { DESARROLLO } \\
\text { RURAL }\end{array}$ & CORREGIMIENTOS & ZONA RURAL & \multirow{8}{*}{$\begin{array}{c}\text { ZONA } \\
\text { URBANA }\end{array}$} \\
\hline \multirow{2}{*}{$\begin{array}{c}\text { NUESTRA } \\
\text { SEÑORA LA } \\
\text { CANDELARIA } \\
\text { DE LA } \\
\text { MONTAÑA }\end{array}$} & \multirow{6}{*}{-------} & EL SALADO & & \multirow{7}{*}{$\begin{array}{c}110 \\
\text { COMUNIDADES }\end{array}$} & \\
\hline & & PUEBLO VIEJO & & & \\
\hline \multirow{2}{*}{$\begin{array}{c}\text { SAN } \\
\text { LORENZO }\end{array}$} & & SAN LORENZO & \multirow{2}{*}{ SAN LORENZO } & & \\
\hline & & SAN JERONIMO & & & \\
\hline \multirow{2}{*}{$\begin{array}{c}\text { CAÑAMOMO } \\
\text { Y } \\
\text { LOMAPRIETA }\end{array}$} & & QUIEBRALOMO & \multirow{2}{*}{----- } & & \\
\hline & & SIPIRRA & & & \\
\hline (2) & $\begin{array}{c}\text { ESCOPETERA } \\
\text {-PIRSA }\end{array}$ & BONAFONT & BONAFONT & & \\
\hline
\end{tabular}

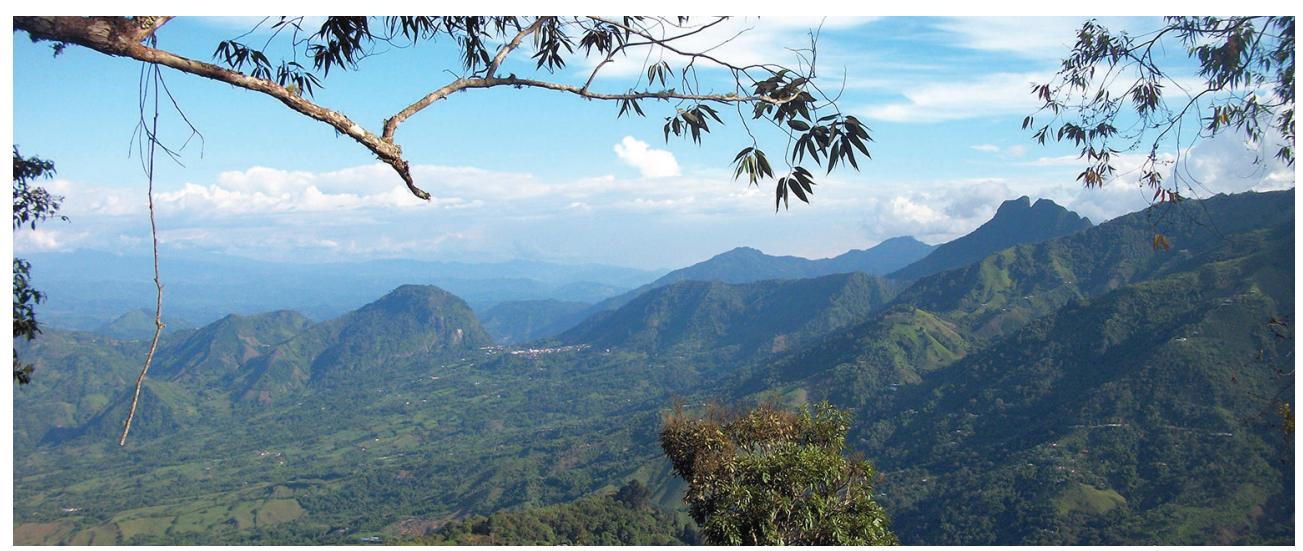

Vista del valle de los Pirzas (Bonafont) desde el cerro Sinifaná 


\section{BIBLIOGRAFÍA}

Abad Salazar, Inés Lucía. Los Ansermas, Tesis de grado, Bogotá, Universidad Javeriana, 1955.

AGN VISITAS-CAU:SC.62,1,D.1 /Anserma, Cartago, Arma, Toro: diligencias de visita a minas (1627). Folios: 1-480 (Visita de Lesmes de Espinosa y Saravia).

AGN. "Los indios del Supía con algunos de los de Cañamomo sobre haberse introducido estos en las tierras de sus resguardos", en: AGN, "Indios de Supía: pleitos por tierras de resguardo” RES-ANT-CAU-TOL: SC.53,1,D.25, págs. $673 \mathrm{v}, 674 \mathrm{r}$, subrayas fuera del texto.

AGN. "Testimonio a favor de los terrenos de Pirsa, año de mil ochocientos sesenta y seis”. Archivo General de la Nación. CO.AGN.SR.60ª.30.12.1.1 / [Resguardo Indígena de Pirsa y Bonafont (Caldas): Existencia] (1939/1939). Folios; 1-26.

AGN.SR.60A.30.12.2.1 /[Resguardo de San Lorenzo, Municipio de Riosucio, Caldas. Planos del resguardo y trascripción de documentos del año 1935] (1939 / 1943). Folios 1-169.

Alcaldía de Riosucio. Documento resumen, anexo al Acuerdo 145 de 2003, que adoptó el PBOT Municipal.

Anales del Congreso del 22 de agosto de 1942.

Anónimo. "Descripción de la Vega de Supía, Provincia de Popayán”. Quito, cerca de 1680. Archivo General de Indias, Sevilla, España. Tomado de la página web del AGI.

Anónimo. "Informe general de los pueblos del Cauca", en: Cespedesia, revista de la Universidad del Valle, Nos. 45 y 46, suplemento $\mathrm{N}^{\circ} 4$, enero-junio 1983, págs. 409-423.

Anónimo. "Por los lugares de Riosucio. El Rosario", en: Hola Riosucio. № 3. Riosucio, junio 2015.

Anónimo. "Relación de Popayán y del Nuevo Reino" de 1559-1560, en: Cespedesia, revista de la Universidad del Valle, Nos. 45-46, suplemento No. 4, enero-junio de 1983.

Anónimo. “Una página del poeta José Trejos”, en Atalaya, Manizales, enero de 1939.

Appelbaum, Nancy. Dos plazas y una nación, Raza y colonización en Riosucio, Caldas, 1846-1948. Bogotá, U. del Rosario / U. de los Andes, 2007. 
Archivo Municipal de Riosucio, Caldas. Libro de escrituras públicas.

Archivo Municipal de Riosucio, Caldas. Libro de Posesiones. Tomo 1. 1895-1920.

Boussingault, Juan Bautista [1824]. Memorias. Tomo II. Bogotá, Banco de la República, Biblioteca V Centenario, 1994.

Bueno Rodríguez, Julián, Historia de Riosucio, sin fecha, 1977 aprox.

Cabildo Indígena de San Lorenzo. Los títulos de San Lorenzo, Riosucio, Cabildo Indígena de San Lorenzo, 2010.

Calvo de Vanegas, Purificación, Riosucio, 1963.

Camacho Roldán, Salvador. Memorias. Medellín, Editorial Bedout, s.f.

Cardona Tobón, Alfredo. "La ocupación paisa de los resguardos indígenas del norte caucano", en: Repertorio Histórico de la Academia Antioqueña de Historia, Año 109, Núm. 30 (Nueva Etapa). Julio-septiembre de 2015.

Concejo Municipal de Riosucio, Caldas. Acuerdo Nº35 del 3 de septiembre de 1965.

Correa, François y Sandra Acero. "Proyecciones del Instituto Indigenista de Colombia en la División de Asuntos Indígenas". Bogotá, Baukara, $\mathrm{N}^{\circ} 3$, Instituto Colombiano de Antropología e Historia (ICANH), mayo 2013.

Cuesta, Rómulo. Tomás. Bogotá, Editorial de Cromos, 1923.

De las Casas, fray Bartolomé. Brevísima relación de la destrucción de las Indias [1551]. Buenos Aires, Ediciones Mar Océano, 1953.

Duque Gómez, Luis. Carta (informe de comisión al Departamento de Caldas), 16 de agosto de 1943. Archivo del ICANH. Bogotá.

Escobar Llanos, Ariel. Historias del viento en la cordillera. $2^{\text {a }}$ ed. Medellín, Editorial Lealón, 1989.

Escritura No 263 de 1903 de la Notaría de Riosucio (Protocoliza pleito entre los pueblos de Lomaprieta y La Montaña, 1721-1722).

Escritura No. 54 del 8 de octubre de 1874 de la Notaría de Supía (Protocoliza división del Resguardo Supía y Cañamomo).

Escritura No.79 de 1936 de la Notaría de Riosucio (Protocoliza título del Resguardo de Cañamomo Lomaprieta).

Friede, Juan. Vida y luchas de don Juan del Valle, primer obispo de Popayán. Popayán, 1961. 
Friede, Juan. Los Quimbayas bajo la dominación española. Bogotá, Talleres Gráficos del Banco de la República, 1963.

García Mejía, Hernando y otros. "Germán Arciniegas a Otto Morales Benítez", en VI Encuentro de la Palabra, Manizales, Biblioteca de Escritores Caldenses, 1990.

Gartner Posada, Álvaro. "Caciques de La Montaña”, ponencia presentada en el Foro “475 años del nombre de Riosucio" en 2013, inédito.

Gartner Posada, Álvaro. “Fundación de Riosucio. Un pueblo del siglo XVIII”. Cali, agosto de 1999, mimeo, incluido en el CD "Cátedra Riosuceña".

Gartner Posada, Álvaro. "Tras las huellas del padre Bonafont en el Archivo Central del Cauca. Elementos para una nueva visión de la fundación de Riosucio", conferencia, 1994, inédita.

Gartner, Jorge. Memoria al Congreso de 1939, Ministerio de la Economía Nacional.

Giraldo de Puech, María de la Luz y Diana Castellanos. Así éramos los Quimbayas. Bogotá, Fundación de Investigaciones Arqueológicas Nacionales, Banco de la República, 2010.

González Escobar, Luis Fernando. Ocupación, poblamiento y territorialidades en la Vega de Supía, 1810-1950. Ministerio de Cultura. Premio de Historia del Departamento de Caldas, 2002.

González Jaramillo, José Manuel. Transcripción del resumen de la visita de Lesmes de Espinosa y Saravia a la Provincia de Anserma en 1627, de las Ordenanzas de Anserma y de la visita al pueblo de Pirza, tomadas del Archivo General de la Nación, inédito, 2013 y 2015.

Guillén Chaparro, Francisco. "Memoria sobre Popayán, 1583", en: Cespedesia, revista de la Universidad del Valle, Nos. 45-46, suplemento No. 4, enero-junio de 1983.

Gutiérrez, Rufino. Monografías, tomo II, Biblioteca de Historia Nacional, tomo XXXVIII, Bogotá, Imprenta Nacional, 1921.

Hettner, Alfred. "Viaje por los Andes colombianos (1882-1884)", en: Viajeros por el antiguo Caldas. Manizales, Academia Caldense de Historia, 2008.

IGAC, Subdirección de Catastro Nacional. "Informe de límites. Resguardo de La Montaña (La Montaña y San Lorenzo). Municipio de Riosucio. Departamento de Caldas". Bogotá, 1984.

IGAC. "Informe de límites de la Comunidad Escopetera-Pirza. Municipio de Riosucio - Departamento de Caldas. Municipio de Quinchía-Departamento de Risaralda”. Santafé de Bogotá, 1994. 
Iragorri, Luis Carlos. Apuntes para un estudio económico y fiscal del Cauca. Popayán, 1962.

Liévano Aguirre, Indalecio. Los grandes conflictos sociales y económicos de nuestra historia. Tomo I. Bogotá, Tercer Mundo, 1972.

López, José Luis. Memoria del Ministro de la Economía Nacional al Congreso de 1946. Tomo I. Bogotá, Imprenta Nacional.

Mayorga García, Fernando. "La propiedad territorial indígena en la Provincia de Popayán (1831-1857): continuidad del proteccionismo, situación de excepción frente a lo dispuesto en otras provincias". Revista Precedente de la Universidad Santiago de Cali, vol. 2, enero-junio de 2013.

Mayorga García, Fernando. “Norma general, norma especial: el Código Civil de 1887 y la Ley 89 de 1890. Un caso de regulación protectora de las minorías durante la Regeneración", en: Revista Mexicana de Historia del Derecho, № 27, UNAM, Instituto de Investigaciones Jurídicas, 2013.

Montoya Guzmán, Juan David y José Manuel González Jaramillo, transcriptores. Visita a la provincia de Antioquia por Francisco de Herrera Campuzano, 16141616. Medellín, Colección Bicentenario de Antioquia, Universidad Nacional de Colombia, 2010.

Morales Benítez, Otto. Testimonio de un pueblo. Bogotá, Antares, 1951.

Parsons, James. La colonización antioqueña en el occidente colombiano. Medellín, Imprenta Departamental de Antioquia, 1950.

Pérez Salazar, Honorio. "Emancipación del indígena de resguardo", en: Gustavo Ardila Urueña, La problemática indígena en Colombia Katío. Pereira, Fondo Editorial de la Gobernación de Risaralda, 1984.

Pineda Giraldo, Roberto. "Inicios de la antropología en Colombia”, en: Revista de Estudios Sociales. Bogotá, Universidad de los Andes, junio de 1999.

Robledo, Jorge. "Descripción de los pueblos de la provincia de Anserma” [ca. 1543], en: Hermes Tovar Pinzón. Relaciones y visitas a los Andes, siglo XVI. Bogotá, Instituto de Cultura Hispánica, 1993.

Roldán Ortega, Roque, compilador. Fuero Indígena Colombiano. Bogotá, Presidencia de la República, 1990.

Sanz Álvarez, Jaime Enrique. Historia Judicial de Caldas. Libro primero. Manizales, sin editor, 2013 aprox. 
Ugarte Rico, Alejandro, Merardo Largo y Fernando Uribe. Historia de Guacuma. Quinchía, Risaralda, Servimpresos publicidad, 2013.

Valencia Llano, Albeiro. Colonización: Fundaciones y conflictos agrarios (Gran Caldas $y$ Norte del Valle), 2a ${ }^{\text {a }}$ ed. Manizales, 2000.

Vinasco Trejos, Rafael. Apuntes sobre Riosucio. Edición póstuma de la familia, 2005.

Zulueta Cebrián, Carmen de. Caminos de España y de América, Madrid, Ed. Residencia de Estudiantes, 2000. 

Este libro terminó de imprimirse en el mes de noviembre de 2018, en los talleres gráficos de Publiprint S.A.S., bajo el cuidado del autor.

Pereira, Risaralda, Colombia. 
La Editorial de la Universidad Tecnológica de Pereira tiene como política la divulgación del saber científico, técnico y humanístico para fomentar la cultura escrita a través de libros y revistas científicas especializadas.

Las colecciones de este proyecto son: Trabajos de investigación, Ensayos, Textos Académicos y Tesis Laureadas.

Este libro pertenece a la Colección ensayos de la Maestría en Historia. 

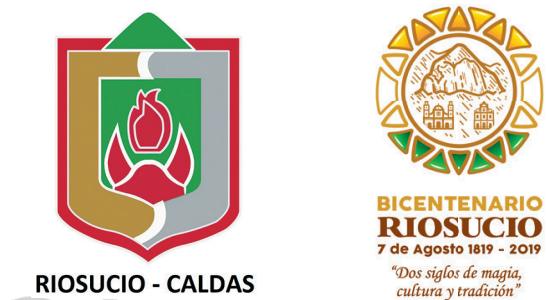

7 de Agosto 1819 - 2019

"Dos siglos de magia,

RIOSUCIO - CALDAS

cultura y tradición"

El Municipio de Riosucio, Caldas, tiene la particularidad de haber sido fundado el 7 de agosto de 1819, la misma fecha de la batalla de Boyacá, por lo que el maestro Germán Arciniegas escribió que "Riosucio es la imagen de la República".

Esta frase es más que un eslogan, ya que Riosucio se ubica en las mismas tierras de Quiebralomo, Supía y Marmato, ricas en oro de veta y de aluvión, por lo que figura en la historia desde los tiempos de la Conquista, y desde entonces cada época y cada acontecimiento importante del país, incluyendo la Constitucón de 1991, ha dejado su impronta sobre territorio riosuceño, por lo que al hablar de Cinco Siglos de Historia de Riosucio se compendia también la historia del Gran Caldas y del país.

El presente trabajo es el resumen de una amplia investigación sobre la historia del territorio de Riosucio que el autor emprendió desde 2009 por encargo de los Resguardos Indígenas, una veces, y de la Alcaldía, otras, con la finalidad de contribuir a entender la compleja territorialidad de este municipio, a través de un relato breve y coherente de su historia y de su trayectoria jurídica; así como servir de insumo al ordenamiento territorial de la localidad.

elSBN: 978-958-722-542-6

ISBN: 978-958-722-307-1

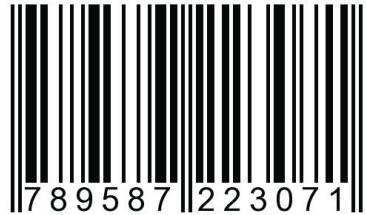

Universidad Tecnológica de Pereira 